\title{
Article
}

\section{Institutional Racism: Judicial Conduct and a New Theory of Racial Discrimination}

\author{
Ian F. Haney López ${ }^{\dagger}$
}

\section{CONTENTS}

I. INTRODUCTION

II. DisCRIMINATION IN THE SELECTION OF LOS ANGELES COUNTY

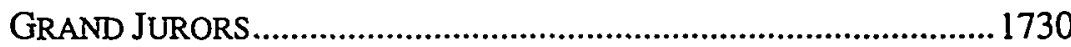

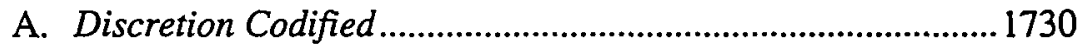

B. Judicial Practice: Friends and Neighbors...............................1732

C. Inside the Circle .....................................................................1735

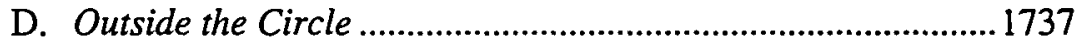

E. Extraracial Discrimination .......................................................1740

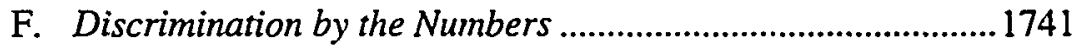

G. Jury Discrimination and the Southwestern Justice System.....1743

H. Nondiscrimination .................................................................. 1744

$\dagger$ Assistant Professor of Law, University of California, Berkeley (Boalt Hall). Many of the ideas developed here were first presented in faculty talks at the Yale and Harvard Law Schools, as well as before the Yale University Center for the Study of Race. Inequality, and Politics: the University of Rochester Department of Political Science; and the Department of Sociology and the American Cultures Program at the University of Michigan. Ann Arbor. I appreciate the many contributions made by participants in those exchanges. Others who deserve recognition and my thanks for their help with this project include Alan Lepp and my colleagues Rober Cooter. Lauren Edelman, Angela Harris, Daniel Rodríguez, Edward Rubin. Jeff Selbin. and Charles Weisselberg. Linda Krieger, Rachel Moran, and Roben Post have been especially generous with their time and insights. Priscilla Battis deserves special recognition for her help and humor in her capacity as my legal assistant. I also wish to thank Ron Dor for his research assistance, and I gratefully acknowledge the generous suppor of the University of Califomia, Berieley, especially in its concrete expression as a semester's leave from teaching in the spring of 1999. Finally, mil gracias to my wife, Deborah Drickersen Córez. 


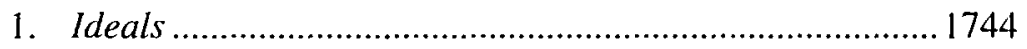

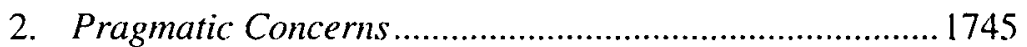

3. Symbolic Importance …………....................................... 1747

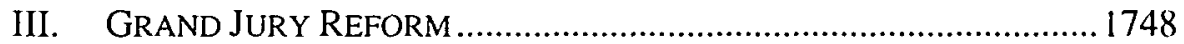

A. Legislative Grand Jury Reform .............................1749

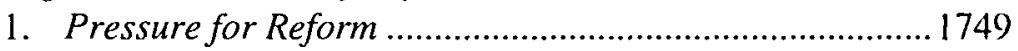

2. Criminal Grand Juries ................................................... 1749

B. Judicial Grand Jury Reform ................................................1750

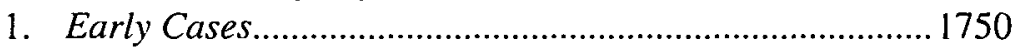

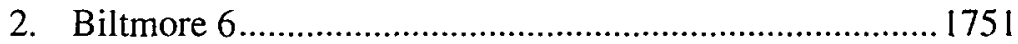

3. California Appellate and Federal District Court Oversight ...................................................................1752

4. The Limits of Superior Court Reform ............................... 1753

5. Grand Juror Selection Practices in 1999 .......................... 1755

IV. THE LIMITS OF INTENTIONAL DISCRIMINATION MODELS...............1757

A. The Centrality of Intent in Discrimination Models .................. 1757

B. Rational Choice Theories of Discrimination ……….................1761

C. Intent in Rational Discrimination Theories ............................ 1764

V. TOWARD AN INSTITUTIONAL APPROACH ....................................... 1769

A. New Institutionalism and Ethnomethodology ........................1770

1. Cognition and Rationality ............................................... 1770

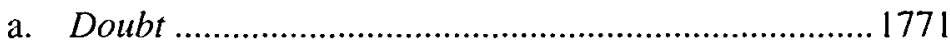

b. Trust and Sense-Making ............................................ 1772

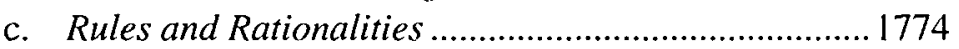

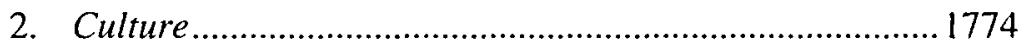

a. The World in Common .............................................. 1775

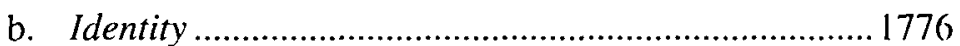

B. New Institutionalism and Social Science Theories of

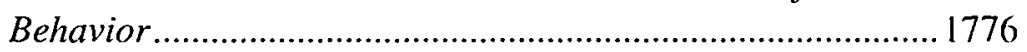

1. From Low to High Construction ..................................... 1777

2. From Directed to Undirected Behavior ...........................1779

C. Script and Path Institutionalism ...........................................1781

D. New Institutionalism and Rational Choice Theory .................. 1783

VI. INSTITUTIONAL ANALYSIS AND THE LOS ANGELES SUPERIOR

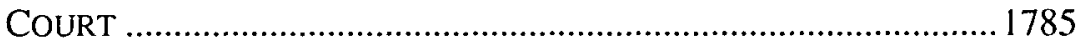

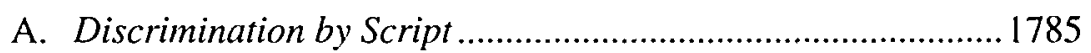

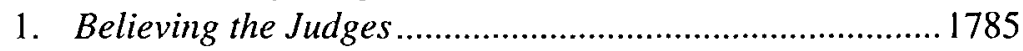

2. Scripts in Organized, Office-Holding Environments........ 1786

3. Uniformity of Selection Practices ....................................... 1790

4. Criteria, Routine, and Legitimacy in Grand Juror Selection 
a. Criteria and Instructions............................................1792

b. Routine Discrimination ...............................................1793

c. Legitimate Discrimination ..........................................1796

B. The Persistence of the "Pick Your Friends" System and

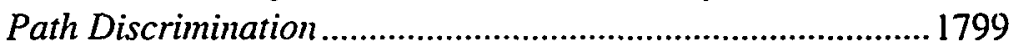

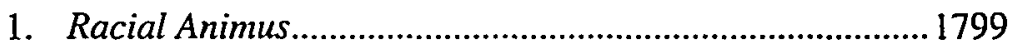

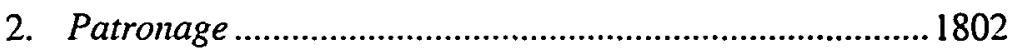

3. The Need for Qualified Grand Jurors ..............................1802

4. The Nomination of Qualified Grand Jurors ...................... 1803

5. Path Discrimination ........................................................... 1804

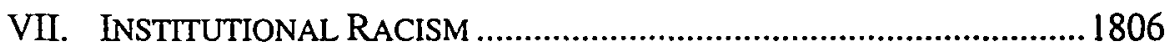

A. Racial Institutions and Unconscious Racism............................1806

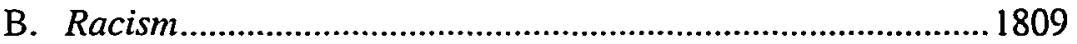

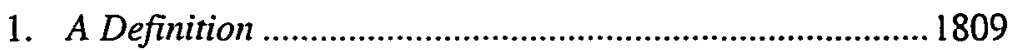

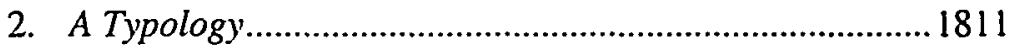

C. Racial Institutions in Los Angeles...........................................1812

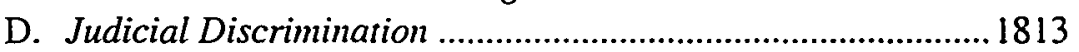

1. Script Discrimination ......................................................1813

a. Favoring Whites.........................................................1813

b. Disfavoring Mexican Americans................................1814

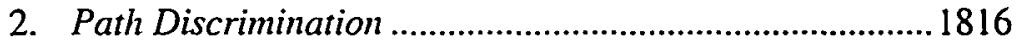

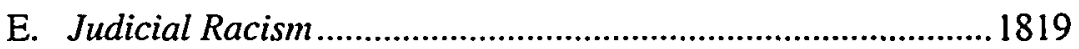

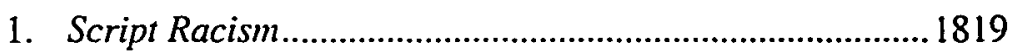

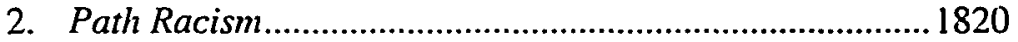

3. Purposeful Racism.......................................................1820

F. Reconsidering Institutional Racism Theory ..............................1822

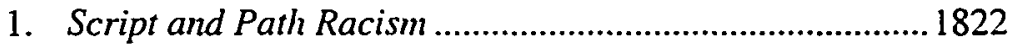

2. Institutional and Purposeful Racism ...............................1823

VIII. CONCLUSION: INSTITUTIONAL RACISM'S DOCTRINAL AND

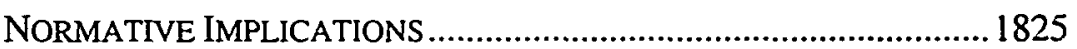

A. The Ubiquity and Intractability of Institutional Racism .......... 1827

B. Institutional Racism and Equal Protection .............................1830

1. Limiting Equal Protection .............................................. 1832

2. Racism in Recent Supreme Court Equal Protection

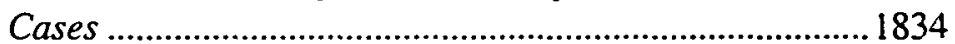

a. Redefining Racism ....................................................1835

b. Reserving the Power To Define Racism......................1838

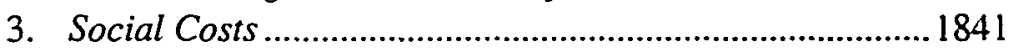

C. Some Normative Implications of an Institutional Account of Racism. 
APPENDICES 1845

APPENDIX A: EXCERPTS FROM THE EAST LA 13 TRANSCRIPT

REGARDING GRAND JURY NOMINEES. 1845

APPENDIX B: SUMMARY OF THE RELATIONSHIP BETWEEN JUDGES AND

GRAND JURY NOMINEES 1876

APPENDIX C: THE CROSS-SECTION REQUIREMENT 1877

APPENDIX D: SUMMARY OF GRAND JUROR SELECTION METHODS IN TWENTY CALIFORNIA COUNTIES, 1999 1884 
When individuals disagree on elementary justice, their most insoluble conflict is between institutions .... The more severe the conflict, the more useful to understand the institutions that are doing most of the thinking. Exhortation will not help. Passing laws against discrimination will not help. ... Only changing institutions can help. We should address them, not individuals, and address them continuously, not only in crises.'

\section{INTRODUCTION}

In 1968, the Los Angeles grand jury indicted thirteen activists on charges ranging from disturbing the peace to conspiracy for their roles in supporting a series of student protests in the predominantly MexicanAmerican area of East Los Angeles. ${ }^{2}$ The defendants, represented by Oscar Acosta and others, claimed the protections of both the First and the Fourteenth Amendments. ${ }^{3}$ In 1970, they prevailed on free speech grounds." Meanwhile, however, three of the original thirteen defendants were among six persons indicted in 1969 on arson and burglary charges arising from protests staged at the Biltmore Hotel in downtown Los Angeles during a banquet talk by Ronald Reagan, then California's governor.' Again

1. MARY DOUGLAS, HOW INSTITUTIONS THINK $125-26$ (1986).

2. See People v. Castro, No. A-232902 (Cal. Super. C. 1968). During the week of March 5. $1968,10,000$ students walked out of the high schools of East Los Angeles. Protesting the abysmal conditions in those schools, the students carried signs that read "Education Not Contempt." "We Demand Schools that Teach," "Good Schools for All." and "Brown is Beautiful." The walkouts marked the mass entrance of Mexican-American youth onto the turbulent field of civil rights protest. See CARLOS MUÑOZ, JR., YOUTH, IDENTITY, POWER: THE ChICANo MOVENENT at Xi (1989). On this era, see generally IgnaCio M. Garcla. Chicanismo: THE Forging of a MIITANT ETHOS AMONG MEXICAN AMERICANS (1997). On the history of Mexican Americans in Los Angeles, see generally RODOLFO F. ACUÑA, A COMMUNTTY UNDER SIEGE: A CHRONICLE OF CHICANOS EAST OF THE LOS ANGELES RIVER, 1945-1975 (1984); RICHARD GRISWOLD DEL CASTILLO, THE LOS ANGELES BARRIO, 1850-1890: A SOCIAL HISTORY (1979): RICARDO ROMO, EAST LOS ANGELES: HISTORY OF A BARRIO (1983); and GEORGE J. SANCHEZ, BECOMING MEXICAN AMERICAN: ETHNICITY, CULTURE, AND IDENTITY IN CHICANO LOS ANGELES, 19001945 (1993).

3. Oscar Acosta, a former legal aid attorney in Oakland and a self-described "revolutionary," carved a volatile figure. Acosta memorialized his remarkable life and especially his years in East Los Angeles in OSCAR ZETA ACOSTA. THE AUTOBIOGRAPHY OF A BROWN BUFFALO (1972); and Oscar Zeta Acosta, THe Revolt of the Cockroach PEOPLE (1973). See also IlaN STAVANS, BANDIDO: OSCAR "ZETA" ACOSTA AND THE CHICANO EXPERIENCE (1995).

4. See Castro v. Superior Court, 88 Cal. Rptr. 500 (Ct. App. 1970).

5. See People v. Montez, No. A-244906 (Cal. Super. Ct. 1969). The setuing was the California Department of Education's third annual Nuevas Vistas ("New Horizons") Conference, dedicated to exploring educational issues salient to the Mexican-American community in Califomia. As Governor Reagan rose to speak, a fire ignited by emergency road flares broke out in a linen storage area on the hotel's tenth floor. Within minutes, new blazes enupied on the ninth, fourth. and second floors, as well as in the ballroom adjacent to where Governor Reagan was speaking. Firefighters quickly extinguished the flames, forestalling the evacuation of anyone from the hotel. See Fires, Protests Jar Reagan Talk, L.A. HeRALD EXAMINER, Apr. 25, 1969, at Al. Unaware of the commotion, Governor Reagan continued his speech. He was soon internupted, however, by a dozen demonstrators in the audience who rose to their feet, shouting and clapping in protest. 
represented by Acosta, but this time without a plausible free speech argument, the defendants raised anew the equal protection defense. The judge hearing the case rejected their constitutional challenge, though a jury subsequently acquitted the defendants. ${ }^{6}$ In both cases, the defendants were tried before the Los Angeles superior court.

I use these cases, known respectively in the Mexican-American community as East LA 13 and Biltmore 6, to address the nature of institutional racism. The defendants' Fourteenth Amendment challenge rested on the claim that the selectors of the 1968 and 1969 Los Angeles grand juries had excluded Mexican Americans. ${ }^{7}$ Significantly, however, Los Angeles superior court judges had nominated all grand jurors, and the defendants' strategy for proving their discrimination claim involved examining on the witness stand more than 100 judges over the course of both cases. Although the records in these cases are incomplete, a transcript exists of Acosta's questioning of thirty-three judges in East LA $13 .{ }^{8}$ This transcript, which records Acosta's interrogation of the judges regarding how and why they made the selections they did, constitutes the principal raw material for this Article. The transcript's most striking aspect is this: While the record reveals in stark numbers the near total exclusion of Mexican Americans from service on grand juries in Los Angeles over the decade preceding these cases, each judge testified that he harbored no intention to discriminate. ${ }^{9}$ Almost immediately, police rushed the banquet room and hustled the protesters out. After the
police swept through, the audience gave the Governor a standing ovation. and he resumed his
speech, calling on Mexican Americans to advise the government on "the most effective ways to
reach the youngster from a Latin cultural background and motivate him to make the adjustment
into our competitive, English-speaking society." Tom Newton, Demonstration Disrupts Talk by
Governor, L.A. TimES, Apr. 25,1969 , at 1; see also Help Us Help You. Reagan Tells Hispano
Educators, L.A. HERALD EXAMINER, Apr. 25, 1969, at A3.

6. See Ron Einstoss, Two Acquitted After Biltmore Jurors Deadlock: Remaining Two Granted Mistrial by Judge; Jury Cites Witness Credibility, L.A. TiMES, Sept. 14. 1971. \$ II, at 1: see also Montez v. Superior Court, 88 Cal. Rptr. 736, 738 (Ct. App. 1970).

7. A comment regarding nomenclature is appropriate here. In this Article. I principally address the experiences of "Mexican Americans," by which I mean all permanent immigrants to the United States from Mexico and their descendants, as well as persons descended from Mcxican inhabitants of the region acquired by the United States under the Treaty of Guadalupe Hidalgo. A longstanding debate surrounds this term as well as others intended to refer to Mexican Americans. See ROdolfo ACUNA, OCCUPIEd AMERICA: A History OF CHICANOS at ix-x (1988); MUÑoz. supra note 2, at 7-12. In addition, I sometimes refer to "Latino/as," permanent immigrants from. or descendants of persons from, one of the Spanish-speaking countries of the Western Hemisphere. I adopt the convention of using a virgule at the end of "Latino," rendering it "Latino/a," in response to the gendered grammar of Spanish. See lan F. Haney Lópe 2 . Racee. Ethnicity, Erasure: The Salience of Race to LatCrit Theory, 85 CAL. L. REv. 1143, $1143 \mathrm{n} .1$ (1998). I also capitalize all racial group names, White included. See IAN HANEY LOPFZ. WHITr: BY LAW: THE LEGAL CONSTRUCTION OF RACE at xiv (1996)

8. See Motion to Quash Indictment, People v. Castro, No. A-232902 (Cal. Super. Ct. 1968) [hereinafter Transcript] (on file with the Oscar Zeta Acosta Papers. California Ethnic and Multicultural Archives, Department of Special Collections, University of California, Santa Barbara).

9. I use the masculine pronoun advisedly, as all of the judges to testify in East LA 1.3 were male. See Appendix A. 
This Article seeks to elaborate a theory of racism capable of reconciling the statistical evidence of judicial discrimination with the judges' insistence that they never intended to discriminate..$^{10}$ More generally, it sets out to build a theory of racism that explains organizational activity that systematically harms minority groups even though the decision-making individuals lack any conscious discriminatory intent. This more general goal is important because, in the contemporary setuing, such racism constitutes a significant source of social harm; on balance, it may well constitute the greatest source of ongoing harm to minority communities.

To fashion such a theory of racism, I turn to institutional analysis, and in particular to New Institutionalism, a genre within organizational sociology. ${ }^{11}$ New Institutionalism rejects the rational action theories that animate so much of social science. ${ }^{12}$ Instead, New Institutionalism posits that frequently repeated but largely unexamined social practices or patterns at once structure and give meaning to human interaction. ${ }^{13}$ This claim has both cognitive and cultural components.

On the cognitive level, institutional analysis postulates that through the operation of various mental processes. frequently repeated patterns of activity relatively quickly take on an unexamined, rule-like status such that they are spontaneously followed and disrupted only with difficulty. Put differently, New Institutionalism argues that to a significant degree human behavior is not consciously motivated, or at least not principally so, but instead stems from the unconsidered repetition of cognitively familiar routines. Institutional analysis posits that we often act in definable ways without a consciously formulated purpose, simply because it is "the way it is done."

It is not mere habit, however. New Institutionalism also makes the cultural claim that routinized sequences of behavior eventually come to define normalcy, or more broadly, reality. ${ }^{14}$ Established constellations of action are seen but not noticed, relied upon but not considered, to such an

10. For an extended argument that discnmination against Mexican Americans constitutes "racial" discrimination, see Haney Lopez, supra note 7; and lan F. Hancy López. The Social Construction of Race: Some Obsen'ations on lllusion. Fabrication. and Choice. 29 HARV. C.R.C.L. L. REV. 1 (1994).

11. New Institutionalism as a named project within sociology traces back to Paul J. DiMaggio \& Walter W. Powell. The Iron Cage Revisited: Institultonal Isomorphism and Collective Rationality in Organizational Fields, 48 AM. SOC. REV. 147 (1983). References to New Institutionalism here are to the genre most common to sociology. There are also "new institutionalisms" in political science and economics. See STRUCTURING POLITICS: HISTORICAL INSTITUTIONALISM IN COMPARATIVE ANALYSIS (Sven Steinmo cl al. cods., 1992): OL.IVER E. WILLIAMSON, THE ECONOMIC INSTITUTIONS OF CAPITALISM (1985).

12. See Paul J. DiMaggio \& Waiter W. Powell, Introduction to THE NEW INSTIUTIONALISM IN ORGanIZATIONAL ANALYSIS 1, 22-27 (Walter W. Powell \& Paul J. DiMlaggio eds., 1991).

13. See Roger Friedland \& Roben R. Alford, Bringing Socien Back In: Symbols, Practices, and Institutional Contradictions, in THE NEW INSTITUTIONALISM IN ORGANIZATIONAL ANALYSIS, supra note 12, at 232.

14. See PETER L. BERgER \& THOMAS LUCKMANN, THE SOCIAL CONSTRUCTION OF REALITY: A TREATISE IN THE SOCIOLOGY OF KNOWLEDGE $5+$ (1966). 
extent that they become natural-" the world of daily life known in common with others and with others taken for granted." 15 Thus, accepted complexes of action become paths for forming judgments about the social world, even as they provide the terms by which one acts in that world. These frequently repeated, rule-like, socially ordering grammars constitute the "institutions" at the heart of New Institutionalism.

"Institution" thus takes on a distinct technical meaning: In New Institutionalism, it refers not to organizations, but rather to practices. ${ }^{16}$ Drawing on the cognitive and cultural insights described above, New Institutionalism does not treat particular organizations as institutions so much as it treats the "appropriate" form and structure of organizations as institutionalized. ${ }^{17}$ Fo: New Institutionalists, the most decisive aspects of any particular organization lie not in its formal features, but rather in the way they more generally reflect received templates. The general form adopted by organizations engaged in particular tasks, the means that are regularly chosen and those that are not, the expected goals, the accepted measures of success or failure-all of these reflect unexamined understandings of what is organizationally appropriate. Institutional analysis suggests that it is these, the institutionalized aspects of organizational life, that most deserve critical attention. Thus, the Los Angeles superior court exists both as a specific organization and as a particular embodiment of institutionalized "court-like" practices, but it is in the latter sense, rather than as a unique organization, that this court is of interest here.

I seek to develop a theory of individual behavior within organized settings because "whatever the scale of the organizational context all

15. HAROLD GARFINKEL, STUdIES IN ETHNOMETHODOLOGY 35 (1967).

16. Ronald Jepperson describes "institutions" as follows:

[I]nstitutions are those social patterns that, when chronically reproduced, owe their survival to relatively self-activating processes.... All institutions are frameworks of programs or rules establishing identities and activity scripts for such identities.... Institutions are taken for granted ... in the sense that they are both treated as relative fixtures in a social environment and explicated (accounted for) as functional elements of that environment.

Ronald L. Jepperson, Institutions, Institutional Effects, and Institutionalism, in THE NEW INSTITUTIONALISM IN ORGANIZATIONAL ANALYSIS, supra note 12, at 143, 157 (footnotes omitted). Jepperson suggests that the following qualify as institutions: marriage, sexism, the contract, wage labor, academic tenure, the Presidency, the vacation, the handshake. the corporation, insurance, and voting. See id. at 144. Note that whereas institutions consist of unconsidered practices, organizations can be understood as systems of coordinated activitics structured in complex networks of formal relations. See John W. Meyer \& Brian Rowan. Institutionalized Organizations: Formal Structure as Myth and Ceremony, in THE NEW INSTITUTIONALISM IN ORGANIZATIONAL ANALYSIS, supra note 12, at 41.

17. According to DiMaggio and Powell, " $[\mathrm{N}]$ eoinstitutionalists view institutionalization as occurring at the sectoral or societal levels, and consequently interorganizational in locus. Organizational forms, structural components, and rules, not specific organizations, are institutionalized. Thus, where the old institutionalism viewed organizations as organic wholes, the new institutionalism treats them as loosely coupled arrays of standardized elements." DiMaggio \& Powell, supra note 12, at 14. 
discrimination involves individual actors." 18 However, many New Institutionalists stress structural approaches to action that essentially ignore individualist models of social activity. ${ }^{19}$ Although rooted in the work of social constructionist scholars who studied individual interactions, such as Harold Garfinkel, Peter Berger, and Thomas Luckmann, ${ }^{20}$ New Institutionalism focuses on organizational structures rather than on individuals. This Article develops a theory of institutional analysis that borrows from New Institutionalism even as it emphasizes-more so than other writings within that genre-Harold Garfinkel's earlier theorizing on individual cognition. By emphasizing Garfinkel's insights and combining these with New Institutionalism's study of organizations, I develop an approach that looks not to organizations per se, but to individual behavior within organized settings. ${ }^{21}$ As with New Institutionalism, the institutional approach I follow rejects models of behavior that posit that actors principally pursue tasks either out of a strategic calculation of their interests or as a conscious effort to abide by internalized value systems. Rather, I advance an institutional analysis in which organizational actors follow elaborate scripts, spontaneously triggered complexes of behavior. I also argue that even when specific scripts do not develop or are not followed, paths come into play, unexamined background understandings that effectively specify the range of legitimate action.

I intend to shed light on judicial decision-making processes that give rise to discrimination by applying institutional analysis to the Los Angeles superior court's grand juror selection practices. Judges in particular and law as a whole have not received much sustained attention from New Institutionalism. ${ }^{22}$ Instead, New Institutionalism tends to depict law in a rather formal way, as an undifferentiated constraint on organizational life. ${ }^{23}$

18. Joe R. Feagin \& Clairece BoOker FEagin, DisCrimination american Style 25 (1986).

19. See Jepperson, supra note 16, at 154.

20. See GARFINKEL, supra note 15; BERGER \& LUCKMANN, supra note 14. DiMaggio and Powell note the influence of Garfinkel's as well as Berger and Luckmann's work on the rise of New Institutionalism. See DiMaggio \& Powell, supra note 12, at 19-22.

21. Note that there is no sharp distinction between the institutional analysis I employ here and that typical of New Institutionalism: rather, they are largely compatible. Indeed, although somewhat in the minority, some New Institutionalists also focus on individual behavior. See, e.g., Lynne G. Zucker, The Role of Institutionalization in Cultural Persistence, in THE NEw INSTITUTIONALISM IN ORGANIZATIONAL ANALYSIS, supro note 12, at 83. The point is that my focus on individual behavior within organizations provides a subule but significant difference in emphasis relative to the theorizing of much, but not all. New Institutionalist scholarship.

22. For a recent exception in the area of corporate law, see Donald C. Langevoon. Organized Illusions: A Behavioral Theory of Why Corporasions Mislead Stock Market Investors (and Cause Other Social Harms), 146 U. PA. L. REV. 101 (1997).

23. According to Mark Suchman and Lauren Edelman. "The legal environment depicted by institutional theory is, largely, an environment of 'law-on-the-books': Rules are clear. enforcement is firm, and legal effects are substantive. The ambiguity, the politicization. and the symbolism of the 'law-in-action' tend to fade from view." Mark C. Suchman \& Lauren B. Edelman, Legal Rational Myths: The New Institutionalism and the Law and Sociery Tradition, 21 L. \& SOC. INQUIRY 903, 905 (1996) (reviewing THE NEW INSTITUTIONALISM IN ORGANIZATIONAL ANALYSIS, supra note 12); see also id. at 928 ("[T]he institutionalist outlook 
Nevertheless, legal scholars such as Lauren Edelman, Mark Suchman, and Edward Rubin correctly observe that law constitutes an institutional setting that directly molds the behavior of those within its sphere. ${ }^{24}$ Judges, Rubin rightly notes, "are not individual guardians of the law; they are members of an institution...." ${ }^{25}$ The decision calculus of judges has recently come under scrutiny, principally by those searching for strategic action. ${ }^{26}$ Here, I argue that institutional analysis brings into view important features of the judges' nonintentional decision-making processes-their reliance on scripts, their dependence on paths. Institutional analysis suggests that judicial conduct pursuant to such unexamined decision making often produces discrimination, racial and otherwise.

I do not, however, principally intend to study judicial cognition itself, so much as to theorize a particular form of racism. ${ }^{27}$ When applied to the actions and the words of the superior court judges brought to the stand in East $L A 13$, institutional analysis illuminates the dynamics of a type of conduct perhaps best described as "institutional racism." Stokely Carmichael and Charles Hamilton introduced that term the year before the East Los Angeles student protests. ${ }^{28}$ It gained popularity in the 1970 s and

often comes uncomfortably close to naive Legal Formalism."). Walter Powell agrees with Suchman and Edelman's assessment. See Walter W. Powell, Fields of Practice: Connections Between Law and Organizations, 21 L. \& SOC. INQUIRY 959 (1996).

24. See Lauren B. Edelman, Constructed Legalities: Socio-Legal Fields and the Endogeneity of Law, in BENDING THE BARS OF THE IRON CAGE: INSTITUTIONAL DYNAMICS AND PROCESSES (Walter W. Powell \& Daniel L. Jones eds., forthcoming 2000) (manuscript on file with the author); Lauren B. Edelman \& Mark C. Suchman, The Legal Environment of Organizations, 23 ANN. REV. SOC. 479 (1997); Edward L. Rubin, Legal Reasoning, Legal Process and the Judiciary as an Institution, 85 CAL. L. REV. 265 (1997) (reviewing CASS R. SUNSTEIN, LEGAL REASONING AND POLITICAL CONFLICT (1996)); Suchman \& Edelman, supra note 23.

25. Rubin, supra note 24 , at 281 . Rubin argues not only that institutional analysis of law is desirable, but also that such analysis may afford a possible basis for "a new synthesis of scholarly discourse about law," one incorporating the insights of post-legal-process scholarship, such as law and economics, Critical Legal Studies, and Critical Race Theory. Edward L. Rubin. The New Legal Process, the Synthesis of Discourse, and the Microanalysis of Institutions, 109 HARV. L. REV. 1393, 1393-94 (1996).

26. Consider, for instance, the following thesis:

[J]ustices are strategic actors who realize that their ability to achieve their goals depends on a consideration of the preferences of other actors, of the choices they expect others to make, and of the institutional context in which they act. We, and others, call this a strategic account because the key ideas it contains are drawn from the rational choice paradigm....

Lee Epstein \& Jack Knight, The New Institutionalism (pt. 2), LAw \& CTS. (American Political Science Ass'n, St. Louis, Mo.), Spring 1997, at 4; see also Richard A. Posner, What Do Judges and Justices Maximize? (The Same Thing Everybody Else Does), 3 SUP. CT. ECON. REV. I (1993).

27. Institutional analysis has not previously been applied to racism. Sociology in general, of course, has a long history of interest in the subject. For a longitudinal compilation of sociological writings on race relations, see THE SOCIOLOGY OF RACE RELATIONS: REFLECTION AND REFORM (Thomas F. Pettigrew ed., 1980).

28. See Stokely Carmichael \& Charles V. Hamilton, Black Power: The Politics OF LIBERATION IN AMERICA 4-5 (1967). Carmichael and Hamilton wrotc:

Racism is both overt and covert. It takes two, closely related forms: individual whites acting against individual blacks, and acts by the total white community against the black community. We call these individual racism and institutional racism. . . . 
1980 s as a means of highlighting the continued systematic production of inequality, ${ }^{29}$ despite declines in overt acts of individual racial hostility. "Institutional racism" continues to be frequently invoked by many, including critical race theorists. ${ }^{30}$ Nevertheless, "institutional racism" seems to function more often as a label for a problem than as a theory of social behavior. A theory of "institutional racism" has been elusive.

For some, institutional racism amounts to intentional racism in institutions - that is, purposeful discrimination in formally organized settings. ${ }^{31}$ For others, it refers to widespread race-neutral practices that impose harmful effects on minority communities, irrespective of the actions or attitudes of individual decision makers. ${ }^{32}$ Note that the first model focuses on motivated individual actions, while the second moves in the opposite direction, denying the relevance of individual behavior altogether. I reject both of these approaches.

I propose a model of institutional racism that neither relies on motivated behavior nor dismisses behavior altogether, but rather one that focuses on the sort of nonintentional behavior emphasized by institutional analysis. In this way, the term "institutional racism" functions here on both

When white terrorists bomb a black church and kill five black children. that is an act of individual racism, widely deplored by most segments of society. But when in that same city-Birmingham. Alabama-five hundred black babies dic each year because of the lack of proper food, shelter and medical facilities... that is a function of institutional racism. Id. at 4 .

29. See Nijole Benokraitis \& Joe Feagin. Institutional Racism: A Perspective in Search of Clarity and Research, in BLACK/BROWN/WHTE RELATIONS: RACE REl_ATIONS IN THE 1970S, al 121, 122 (Charles V. Willie ed., 1977).

30. Critical Race Theory has long insisted on the importance of institutional racism, broadly conceived. See Introduction to CRITICAL RACE THEORY: THE KEY WRITINGS THAT FORMED THE MOVEMENT at xvi (Kimberlé Crenshaw et al. eds.. 1995); see also Frank I. Michelman, Foreword: "Racialism" and Reason, $95 \mathrm{MICH}$. L. REv. 723, 728 n.25 (1997) (")[T] CRe CRT premise ... is, of course, precisely that of an institutional racism whose extent and effects far exceed the kinds of expression of it that colorblind law can remedy."). Among the important Critical Race Theory works addressing racism generally are JODY DAVID ARMOUR, NEGROPHOBIA AND REASONABLE RACISM: THE HIDDEN COSTS OF BEING BLACK IN AMIERICA (1997); DERRICK BELl, AND WE ARE NOT SAVED: THE Elusive QUEST FOR RACIAL JUSTICE (1987); DERRICK BELL, FACES AT THE BOTTOM OF THE WELL: THE PERMaNENCE OF RACISM (1992); John O. Calmore, Race/ism Lost and Found: The Fair Housing Act at Thirty. 52 U. MIAMI L. REV. 1067 (1998); Anthony Cook, Culmural Racism and the Limits of Rationality in the Saga of Rodney King, 70 DENV. U. L. REV. 297 (1993): Peggy C. Davis, Law as Microaggression, 98 YALE L.J. 1559 (1989); and Charles R. Lawrence IIl. The ld. the Ego, and Equal Protection: Reckoning with Unconscious Racism, 39 STAN. L. REV. 317 (1987).

31. David Wilkins and Mitu Gulati make a similar observation, as do Nijole Benokraitis and Joe Feagin. See Benokraitis \& Feagin, supra note 29. at 128: David B. Wilkins \& G. Mitu Gulati. Why Are There So Few Black Lawyers in Corporate Law Firms? An Institutional Analysis, 84 CAL. L. REV. 493, 509 (1996).

32. See GERTRUdE EZORSKY, RACISM AND JUSTICE: THE CASE FOR AFFIRMATIVE ACTION 9 (1991) ("Institutional racism occurs when a firm uses a practice that is race-neutral (intrinsically free of racial bias) but that nevertheless has an adverse impact on blacks as a group." ): FEAGIN \& FEAGIN, supra note 18, at 31-33 (discussing "indirect institutionalized discrimination"). For others, institutional racism means any son of discrimination produced by large-scale. stable social arrangements, whether generated through individual action (bigoted or otherwise) or not. See LOUIS L. KNOWLES \& KENNETH PREWITT, INSTITUTIONAL RACISMI IN AMIERICA 5 (1969). 
technical and popular levels. In the technical sense, the phenomenon at issue is institutional racism because it involves unconsidered actions rooted in the sorts of institutions contemplated by New Institutionalism: the background scripts and paths that mark social and organizational life. ${ }^{33}$ In the popular sense, it is institutional racism because it describes activity more likely to arise within the formally organized bodies commonly referred to as institutions-for example, the courts. ${ }^{34}$

This Article is organized as follows. Parts II and III consist of the various elements that together frame the background facts to this Article. In Part II, I outline the grand jury nomination process as provided for by statute. I then examine the actual practices described by the judges in their testimony-the nomination of their friends and neighbors-while also noting the judges' emphatic denials of discriminatory intent. I then turn to the numerical evidence of discrimination, which shows that while Mexican Americans accounted for one of every seven persons in Los Angeles County during the 1960s, they accounted for only one of every fifty-eight Los Angeles County grand jurors. I also review evidence demonstrating the widespread nature of the discrimination evident in East LA 13-widespread in the sense that Mexican Americans were not the only group victimized, and in the sense that such anti-Mexican-American discrimination formed only a small part of a larger pattern of discrimination against that group in the justice system throughout the Southwest. Finally, I discuss the importance of nondiscrimination in grand juror selection.

In Part III, I detail the history of reform-or more pointedly, the lack thereof-in the grand jury system in the years immediately following East LA 13 and Biltmore 6. I also examine contemporary practices of grand juror selection in twenty California counties, finding that in all but one, judges still wield substantial discretionary power. Notably, judges in Los Angeles continue to nominate all grand jurors. I couple this finding with evidence that in the 1990s, Los Angeles superior court judges excluded Latino/as from grand jury service at a six-to-one ratio that rivals the eight-to-one exclusion of Mexican Americans in the 1960s. Institutional racism of the sort ascribed to practices of thirty years past seems to be almost equally prevalent today.

In Part IV, to clarify the theoretical problem this Article addresses, I detail the failure of purposeful action theories of racism to resolve the paradox of discrimination absent discriminatory intent evident in East $L A$ 13. In particular, I critique a recent Harvard Law Review article by Richard

33. Cf. Jepperson, supra note 16 , at 143 (discussing popular references to "institutional racism" in relation to more technical understandings of the term "institution").

34. I delay offering more precise definitions of "racism" and "institutional racism" until near the end of this Article. Developing an institutional analysis of racism does not require careful definitions of those terms at the outset, and such definitions placed early on might prove distracting. See infra notes 350-352 and accompanying text. 
McAdams that modeled racism as rational action. ${ }^{35}$ McAdams's article exhibits several problems in its discussion of racism, but among the most telling is its failure to offer a credible explanation of racist action by those who genuinely claim to have no racist intentions. After highlighting the theoretical challenge posed by nonintentional action, in Part V, I turn to New Institutionalism. There I emphasize the foundational work of Harold Garfinkel and position New Institutionalism in terms of other social science theories of behavior, in particular rational choice theory. I also use this Part to distinguish between competing conceptions of institutional dynamics, suggesting the new language of script and path institutionalism.

Applying New Institutionalism to the facts underlying East LA 13, I begin to develop in Part VI a model of institutional racism. I argue that script and path institutionalism account for many facets of the judges' nomination practices, including features otherwise difficult to explain under other social science theories. In Part VII, I more fully develop the theory of institutional racism. To demonstrate that the judges' institutionalized actions amounted to racism, I introduce the notion of racial institutions, widely shared but unconsidered understandings of race. ${ }^{36}$ I explain the actions of the Los Angeles superior court judges as a function of their subscription to and reliance on racial institutions, positing that such dependence converted institutionalized behavior into institutional racism. To facilitate the discussion, I develop a typology that distinguishes between purposeful and institutional racism, and that further divides the latter along the lines of script and path. I also offer a general definition of racism, explaining my decision to use that loaded term to describe the social practices of exclusion examined here, and finally I address limits to the theory of institutional racism.

To conclude the Article, I consider in Part VIII some doctrinal and normative ramifications of institutional racism theory. ${ }^{37}$ To begin with, I point out that while many social science theories of racism conceive of that phenomenon as exceptional and therefore impermanent, institutional theory pictures racism as both ubiquitous and largely intractable. I then use institutional racism theory to critique central facets of the Supreme Court's contemporary equal protection jurisprudence-its exclusive fascination with purposeful racism, and its increasingly strict equation of purposeful

35. Richard H. McAdams, Cooperation and Conflict: The Economics of Group Status Production and Race Discrimination, 108 HARV. L. REV. 1003 (1995).

36. The emphasis on racial institutions makes clear the exient to which the approach taken in this Article is indebted to, but quite different from, the methodological individualism set forth in perhaps the best known legal work on unconscious racism. Charles Lawrence's The Id, the Ego. and Equal Protection. See Lawrence, supra note 30, at 317.

37. Though I do not explore this point further, note that while the methodology relied on here is predictive, it is not prescriptive in the manner common to legal scholarship. See Edward L. Rubin, Law and the Methodology of Law, 1997 WIS. L. REV. 521. 537, 542. I do not offer prescriptions based on the analysis offered here, though of coursc prescriptive implications of this analysis abound. 
racism with the open consideration of race. Institutional analysis demonstrates that the current Supreme Court's reasoning is exactly backward: Racism occurs frequently-and perhaps predominantlywithout any specific invocation of race, while the explicit consideration of race may have as its aim racism's amelioration rather than perpetuation.

Finally, I turn from doctrinal to normative concerns, considering whether the pallid language of institutionalism is appropriate to the terrible scourge of racism. I argue that because much if not most racial harm now stems from the attenuated cognitive processes described here, we cannot afford to eschew institutional analysis as a theoretical tool. We should view those processes not merely as institutional, however, but as institutional racism - thereby emphasizing the force and urgency of our obligation to respond to these immensely harmful but previously little-recognized social and organizational dynamics.

\section{DisCRIMINATION IN THE SELECTION OF LOS ANGELES COUNTY GRAND JURORS}

Unlike trial jurors, who sit for at most a few civil or criminal trials, grand jurors usually sit for an entire year and serve an independent, quasijudicial, quasi-investigative function. ${ }^{38}$ In California, each county must seat a grand jury, and the juries play two important roles: They operate as part of the criminal justice system, voting or refusing criminal indictments; and they serve as a watchdog over local government, examining the conduct of county officials. ${ }^{39}$ In this Part, I set out the means by which Los Angeles County superior court judges nominated grand jurors, and examine evidence of discrimination against Mexican Americans.

\section{A. Discretion Codified}

In the decade leading up to 1970, the California Penal Code provided a complex set of instructions regarding the selection of grand jurors. ${ }^{40}$ To a large extent, these instructions focused on the role of jury commissioners. ${ }^{41}$ A state statute charged the jury commissioner with the duty to "diligently inquire and inform himself in respect to the qualifications of persons

38. See generally MARvin E. Frankel \& GaRy P. NAFTalis, THE: Grand JuRY: AN INSTITUTION ON TRIAL (1975) (examining the history and operation of grand juries).

39. See California Rural Legal Assistance, A Study of Grand Jury Service by Persons of Spanish Surname and by Indians in Selected California Counties, in U.S. COMM'N ON CIVIL RIGHTS, MEXICAN AMERICANS AND THE ADMINISTRATION OF JUSTICE IN THE SOUTHIWEST 112, 113 (1970) [hereinafter CRLA Grand Jury Study].

40. For a contemporaneous overview of grand juror selection procedures, sec William George Prahl, Comment, The Civil Petitioner's Right to Representative Grand Juries and a Statistical Method of Showing Discrimination in Jury Selection Cases Generally, 20 UCLA L. REV. 581. $631-34$ (1973).

41. See Cal. Penal Code $\S 903.1$ (West 1972). 
resident in his county who may be liable to be summoned for grand jury duty," ${ }^{42}$ and to "return to the judges the list of persons recommended by him for grand jury duty." ${ }^{43}$ In turn, " [t] he judges of the superior court [were to] examine the jury list so returned and from such list a majority of the judges may select, to serve as grand jurors ... such persons as, in their opinion, should be selected for grand jury duty." 4

In fact, however, jury commissioners rarely prepared such lists, and even when they did, judges rarely selected from them. Instead, judges routinely nominated their personal acquaintances. Despite the elaborate procedures spelled out in adjacent provisions of the Penal Code, the Code authorized superior court judges to nominate whom they would, subject only to the minimum qualifications required of all grand jurors: ${ }^{45}$

The judges are not required to select any names from the list returned by the jury commissioner, but may, if in their judgment the due administration of justice requires, make all or any selections from among the body of persons in the county suitable and competent to serve as grand jurors regardless of the list returned by the jury commissioner. ${ }^{46}$

Picking nominees from among social acquaintances constituted the standard practice, the one followed by almost all superior cour judges, including Los Angeles County's. ${ }^{47}$ As one contemporary commentator put it, "The usual practice is for Superior Court judges to submit nominations of whomever they wish for prospective grand jurors." 4 s

42. Id. $\S 903.2$.

43. Id. $\S 903.3$.

44. Id.

45. Prerequisites for grand jury service included the possession of U.S. citizenship, being 21 years of age, one year of residence within the pertinent county, "sufficient knowledge of the English language," and being of ordinary intelligence. CAL. CIV. PROC. CODE $\$ 198$ (West 1982).

46. CAL. PENAL CODE $\$ 903.4$. Not surprisingly', jury commissioners rarely bothered to compile jury lists. As one cour held in rejecting a defendant's claim to have suffered harm because a jury commissioner failed to compile a jury list:

[D] would be unreasonable to interpret the statute to require (the jury commissioner]... to prepare a list of persons qualified to serve as grand jurors... [where the judges] determined the due administration of justice required them to make the selection of grand jurors from among the body of persons in the county.

People v. Goodspeed, 99 Cal. Rptr. 696, 701 (Ct. App. 1972).

47. See CRLA Grand Jury Study, supra notc 39. at 115.

48. Patricia Mar, The California Grand Jun: Vestige of Aristocracy, I PAC. L.J. 36, 41 (1970). Despite the ability to nominate anyone otherwise qualified for grand jury service, judges did not typically select grand jurors directly. Rather, a final step in the selection process placed the gloss of chance over a process that was otherwise largely discretionary. Judicial nominations were compiled into a list, and from this list the county clerk either wrote the names on pieces of paper or assigned markers, placing these in a box from which grand jurors were randomly selected. See CAL. PENAL CODE $\$ \S 900,912$. 


\section{B. Judicial Practice: Friends and Neighbors}

The testimony of Los Angeles superior court judges in East LA 13 confirms that the judges turned almost exclusively to their acquaintances in selecting nominees for grand jury service. Drawing from a list of each judge's nominations over the previous decade, Acosta asked the testifying judges to specify their relationship to each nominee. The results were startling, as judge after judge explained the close social relations he maintained with the persons he nominated; they were, in effect, the judges' friends and neighbors.

Consider the testimony of Judge Joseph Call, on the Los Angeles superior court since $1957 .^{49}$ Acosta here questions Judge Call about several of his nominees:

Q. ... Do you know a Dora Rombeau, R-o-m-b-e-a-u?

A. Very well.

$Q$. How long have you known Mrs. Rombeau?

$A$. Well, it would go back to approximately the very early, early 1950s.... She is the wife of Dr. Rombeau, an outstanding physician, I believe, in Burbank. I know Dr. Rombeau and Mrs. Rombeau because they have been members of the Los Angeles Tennis Club since the early '50s, where I am, met them as members of the club. I see them twice a week on the courts at the Los Angeles Tennis Club, and have since 1950.

$Q$. Do you know a Maureen Campbell? ....

A. Oh, yes, indeed. Yes, indeed.

$Q$. And how long have you known her?

A. Well, let's see. I place the time through her husband, Mr. Alex Campbell of the Los Angeles Herald, and that would go back to the time he joined the Los Angeles Tennis Club.... I joined there in 1932, '33, and Campbell came in in about 1955, and that is when I met his wife, so I'd say from 1955.

$Q$. Thank you. Do you know a Mr. George Goman?

A. Very well. ....

$Q$. Is Mr. Goman a member of the tennis club, too?

A. Yes.

Q. Do you know Mrs. Leona McNeill?

A. Very well.

49. See KENNETH JAMES ARNOLD, CALIFORNIA COURTS AND JUDGES HANDBOOK 292-93 (1968). 
Q. Is she a member of the tennis club?

A. Well, I don't know whether she is. I know she plays there on weekends. She may have what is known as an associate membership through her husband, who is a member. ${ }^{50}$

Judge Call nominated a total of ten people to be grand jurors over the course of twelve years. He knew the five he mentioned in the above exchange as friends from the Los Angeles Tennis Club. In addition, Judge Call testified that he also knew his sixth, seventh, and eighth nominees through the same club. ${ }^{51}$ Of the two nominees he did not know through tennis, Judge Call described one as "an outstanding citizen" whom he had known for approximately ten years when he nominated him, while the other he described as "a forthright member of the community, a housewife, if I remember correctly." 52

Judge Call may be atypical in his nominating practices, but only to the extent that he drew from a narrower circle than did most ${ }_{;}^{33}$ to the extent that Judge Call nominated his friends, his conduct typified that of the other judges. The following colloquy between Acosta and Judge Bayard Rhone regarding the latter's nominees, though lengthy, demonstrates more fully the tendency of judges to select nominees from among close acquaintances:

Q. Do you know a Grant Goodale?

A. I do.

Q. In what capacity do you know Mr. Goodale?

$A$. Oh, I have known him for 30 years, I guess.

$Q$. In what capacity have you known him?

A. A business acquaintance, friend, socially.

$Q$. Do you know a Mrs. Ruth Stransky?

A. I do.

$Q$. How long and in what capacity have you known Mrs. Stransky?

A. I don't know. I suppose 10 or 12 years, neighbor.

$Q$. Do you know a Colonel K. Charles Bean, B-e-a-n?

A. Yes.

$Q$. How long have you known Colonel Bean, and in what capacity?

50. Transcript, supra note 8, at 378-81; see also id. at 561-65 (testimony of Judge Kenneth $N$. Chantry).

51. See id. at 395-96 (testimony of Judge Call regarding Grace Van der Hof. Cornwall Jackson, and Patricia Yeomans).

52. Id. at 376-77 (testimony of Judge Call regarding Mrs. Marius Biencourn).

53. Cf. id. at 561-65 (testimony of Judge Kenneth $N$. Chantry regarding nomination of acquaintances from the Wilshire Country Club). 
A. Well, I guess I have known him about 25 years, and I have met him through the church association.

Q. Did you know a Kenneth Payne?

A. I do.

$Q$. How long and in what capacity did you know Mr. Payne?

$A$. Oh, probably 15 years, and I met him also through the church.

$Q$. Do you know a Charles Fuller?

A. I do.

Q. Was Mr. Fuller a friend of yours?

$A$. Yes, we eventually became very friendly.

$Q$. Do you know a Harold Dryden, D-r-y-d-e-n?

A. I do.

$Q$. How long have you known Mr. Dryden?

$A$. About eight or nine years.

$Q$. In what capacity do you know Mr. Dryden?

A. I met him through various Camellia societies that he belongs to and that I belong to.

$Q$. Sorry, what kind of societies?

A. Camellia societies.

Q. Do you know a Mr. Raymond Abernathy?

A. I do.

Q. How long did you know Mr. Abernathy prior to 1965 ?

A. I suppose 20 years.

$Q$. Was he a friend of yours?

A. Yes....

Q. Do you know a Philip Couturier, C-o-u-t-u-r-i-e-r?

A. I do.

Q. How long had you known Mr. Couturier prior to 1965 ?

A. I met him, I think, in 1952.

$Q$. In what capacity did you know [ ] Mr. Couturier?

A. He was a member of my Masonic Lodge.

Q. Do you know an Avery Munger?

A. I do.

$Q$. How long and in what capacity did you know Mr. Munger?

A. I think I got acquainted with him through our children in Sunday school, and they must have been about eight or nine then, and that would make it about 20 years ago.

Q. [Do you know a] Mr. William Coberly?

A. I do.

$Q$. How long and in what capacity did you know Mr. Coberly? 
A. Let's see. I have known him about six or seven years. He is a member of the board of trustees of my church.

$Q$. What church is this, Your Honor?

A. First Congregational Church of Los Angeles. ${ }^{54}$

Judge Rhone's nominees included a friend of thirty years, a neighbor of ten, church acquaintances of fifteen and twenty-five years, a fellow Camellia society member, a fellow Mason, and a member of the board of trustees of his church. ${ }^{55}$ Judge Rhone traveled in a particular orbit, apparently wider than that of Judge Call, but still quite restricted. The judges' social orbits, however, seemed to mark the outer boundaries of the set of potential grand jurors. Exercising the responsibility to nominate grand jurors, Judges Call and Rhone nominated their neighbors and friends. From outside this circle they drew virtually no one.

\section{Inside the Circle}

In their nominating practices, Judges Rhone and Call typified the conduct of the other superior court judges. In this respect, consider Appendices A and B. Appendix A, which draws from the testimony of the thirty-three judges whom Acosta put on the stand in East LA 13, compiles tables of the judges' nominees. It also excerpts the judges' descriptions of their relationships to the persons they nominated, and characterizes those relationships in several ways-for instance, as "friend" or "neighbor." Appendix B summarizes the results.

Among other things, Appendix B shows the following: The thirty-three judges submitted 255 nominations in the years between 1959 and 1968, though because they nominated several persons more than once, individual nominees numbered only $230 .^{56}$ Keeping in mind that the judges described some nominees in more than one way-for example, as both friend and neighbor-note that the judges characterized fifty-three percent of their nominations as friends, and described twenty-six percent as co-members of a church, civic organization, or club. The judges also described eight percent as neighbors, seven percent as the spouses of acquaintances, and two percent as family members. ${ }^{57}$ In addition, the judges testified that

54. Id. at $660-66$.

55. See id.

56. Judge Emil Gumpert proved the most persistent in nominating the same person over and over, nominating Georges M. George every year between and including 1959 and 1968. See id, at 295. When Acosta asked Judge Gumpert whether he had "made any attempts whatsocver to find qualified persons of Spanish surname to serve on the Grand Jury." the judge answered: "No. 1 thought that I would try to have Mr. George selected, and then I would go from there for another 10 years." Id. at 299.

57. The percentages given are measured in terms of total nominations, rather than in terms of individual nominees. Thus, when Judge Gumpert nominated his friend Georges George 10 times, his brother-in-law twice, and his neighbor once, see id. at 295. 304. the pereentages would show that $77 \%$ of the nominations were of a friend (10 nominations of Georges George out of 13 total 
thirteen percent, or thirty-four, were business acquaintances. However, the judges described twenty-eight of these thirty-four as also friends, neighbors, or co-members of a church, civic organization, or club. ${ }^{58}$ The judges failed to identify just forty-four, or seventeen percent, of all of the nominations, as some sort of social acquaintance. Put the other way, the judges counted fully eighty-three percent of their nominations as social acquaintances (211 out of 255). ${ }^{59}$

While astounding, these numbers should not lead one to conclude that forty-four nominations - those not described as a social acquaintance of some sort - came from outside the judges' social circles. Of these fortyfour, the judges explained that seventeen were recommended by a friend, family relation, fellow club member, or another judge-another seven percent of the total nominations. ${ }^{60}$ In only one case did a judge describe soliciting a nominee's name in order to achieve a cross section of the community on the grand jury. ${ }^{61}$

Two points bear emphasizing here. First, nine out of ten nominees came from within the judges' social circles-the eighty-three percent involving a friend, neighbor, family member, spouse of an acquaintance, or co-member of a club, organization, or church, and the seven percent ascribed to recommendations made by someone within those same circles or a fellow judge. If you did not personally know a judge, or know someone who did, there was little to no chance of serving on the Los Angeles County grand jury. Second, all of the thirty-three judges testified to effectively the same

nominations), $15 \%$ were of a family member (two out of 13 ), and $8 \%$ were of a neighbor (one out of 13). While the percentages offered in this example sum to $100 \%$, that is only because Judge Gumpert described each of his nominees in a manner that could be characterized in a single fashion.

58. Compare Judge Rhone's description of nominee Grant Goodale, see id. at 661 ("Oh. I have known him for 30 years, I guess. . . . A business acquaintance, friend, socially."), with Judge William H. Levit's description of nominee Desmond Moody, see id. at 583 ("I'd say [I have known him for] in excess of 20 years. ... I knew him in business when I practiced law. I think he has been at my house and I have been at his house. I wouldn't say that we are intimate social friends, anything like that, but I know him.").

59. See Appendix B.

60. Compare Judge John Frazer's description of nominee James Cantlen, see Transcript. supra note 8, at 532 (" $[\mathrm{H}]$ is name was suggested to me by one of the other Judges . . . and we both had a very dear mutual friend in San Francisco, and I knew of him by reputation .....") with that of Judge Thomas C. Yager regarding nominee Elizabeth Snayd, see id. at 814 ("I have no recollection of her, except as I have indicated about a few of the others, that $I$ had met her and had a discussion with her, and she was recommended, and I nominated her.").

61. Judge Raymond R. Roberts described his nomination of Eleanor Brown in 1968 in the following terms:

I made a canvass of all of my friends and acquaintances in public life to get people nominated from minority, ethnic, and geographical areas. Either Councilman Bradley or Councilman Mills nominated her as a person who was of the black race and lived in the Watts area, and on their recommendations I nominated her, because there was a paucity of nominees from that area.

Id. at 736 . Although not in response to a question about a particular nominee, one judge did imply that he nominated "the only Negro lady that has served on the Jury for years" out of a concern for securing the representation of a cross section of the community. Id. at 566 (testimony of Judge Kenneth N. Chantry). 
system in selecting nominees: They picked persons casually from among their personal acquaintances. ${ }^{62}$ For some, as for Judge Call, this meant primarily their friends at the club. ${ }^{63}$ For others, as for Judge Rhone, it included their friends at church. ${ }^{64}$ For yet others, it amounted to their friends in the business world, ${ }^{65}$ or their neighbors, ${ }^{66}$ or their colleagues in civic organizations. ${ }^{67}$ Sometimes, to be sure, they relied on the recommendations of fellow judges, but otherwise no judge described a different method of selecting nominees, save the one judge who reported that, once, he had solicited a nomination to increase community representation on the grand jury. ${ }^{68}$ In short, then, the testimony of the judges with respect to the persons they actually nominated suggests that the judges all followed the same practice of nominating persons from within their circle of friends and acquaintances. ${ }^{69}$

\section{Outside the Circle}

While the judges selected nominees from within their social circle, much of Los Angeles County lived beyond their ken. In particular, the judges knew few, if any, Mexican Americans.

Consider again Judge Call. Acosta, noting that Judge Call had drawn eight of his ten nominees from the Los Angeles Tennis Club, questioned the judge regarding the club membership of any Mexican Americans. The judge claimed that tennis champions Pancho Segura and Pancho Gonzales had honorary memberships, as did the captain of the Mexican Davis Cup

62. Consider a former grand juror's description of the typical sclection practice:

Sometimes I think [making grand juror nominations] is lost in the shuffle and maybe a week or a month before grand jury nominations are called for they start around and find out who they play bridge with and this man's wife is par of the bridge circuit.

This man is wanting retirement. This man is tired of golf.

2 CALIFORNIA STATE LEGISLATURE ASSEMBLY INTERIM COMM. ON GOVERNMENTAL EFFICIENCY AND ECON., TRANSCRIPT OF HEARING ON THE CALIFORNIA COUNTY GRAND JURY SYSTEM 36 (1967) [hereinafter EFFICIENCY AND ECONOMY] (iestimony of Skipper Rostker, member of the 1966 Los Angeles County grand jury).

63. See supra notes 51-52; see also Transcript, supro note 8. at 561-64 (Judge Chantry).

64. See, e.g., Transcript, supra note 8, at 662, 665 (Judge Bayard Rhone).

65. See, e.g., id. at 583-86 (Judge William Levit).

66. See, e.g., id. at 404, 408, 410 (Judge George A. Dockweiler).

67. See, e.g., id. at 782-87 (Judge William B. Neelcy).

68. See supra note 61 and accompanying text.

69. The numbers derived from the East $L A / 3$ transcript correspond to similar calculations based on a 1969 survey of Los Angeles superior cour judges regarding their nominations in two years, 1962 and 1968, conducted as part of the defense in the trial of Sirtan Sirtan for the assassination of Robert F. Kennedy. See Mar, supra note 48, at 41-42. The data in Sirhan demonstrated the following:

Fifty-one percent of the nominees were personal friends or neighbors of the judges who nominated them. Another 42 percent were either professional acquaintances. fellow members of a social or service group, or recommended by a friend of the judge. The addresses of the nominees were clustered around the addresses of the judges in the more affluent areas of the county. Few of the nominees were selected from areas where minority groups were concentrated.

Id. at 42 (citations omitted). 
team, though he could not say whether any other Mexican Americans belonged to the 500 - to 700 -member club. ${ }^{70}$

Acosta also asked Judge Call whether he knew any Mexican Americans generally:

$Q$. Do you know any Mexican-Americans, Judge?

A. Well, the gentleman that is a gardener at my house is a Mexican-American. I just signed his citizenship papers. I guess now he is a double-fledged citizen, if that's what you mean.

$Q$. Do you know any persons of Mexican descent who were born here in this country?

A. Mexican descent? If I do, I can't recall them. I probably do. Over the period of my life I have met thousands, hundreds. I have met many, many, but I can't recall it from memory. Undoubtedly, undoubtedly I know many of them. Certainly I do.

Let me see. Born in this country? You are asking the question, saying born here, did you? Or is that right?

$Q$. Yes, sir.

A. Well, of course I do. But I can't enumerate them. It takes in such a vast field.

$Q$. But you do know some?

A. Undoubtedly. ${ }^{71}$

Or consider the questioning of Judge Harold W. Schweitzer, on the bench since the spring of 1952 :

$Q$. I would like to ask you whether or not during the past 10 years you have known any persons of Spanish surname? ${ }^{72}$

A. Yes, I have known many.

$Q$. Approximately how many, Your Honor?

A. I'd say hundreds ... [d] own in Mazatlán, Mexico.

$Q$. Not here in the United States, then?

A. No.

70. See Transcript, supra note 8, at 389-90, 399. Judge Call assured Acosta. "I'm sure honorary memberships have been given to all of those men. They are frequent visitors at the club. frequent." $I d$. at 390.

71. Id. at 386-87.

72. "Persons of Spanish Sumame" reflects the use of surname as a basis for classification by the U.S. Census Bureau. See Bureau of THE CensuS, U.S. DEP'T OF COMmerce. We the MexiCan Americans, Nosotros los MÉxico AmEricanos 4 (1984); see also Frank D. BEAN \& MARTA TIENDA, THE HisPaniC POPULATION OF THE UNITEd STATES 45 (1987) ("Information about Spanish surnames ... was begun in 1950 as a means of identifying the native or native parentage population of Mexican origin."). 
$Q$. Okay. I'm referring to persons here in the United States, Your Honor, specifically in the California area. Do you know any persons of Spanish sumame within the area here, the general area?

A. Yes, I know some.

$Q$. Approximately how many do you know?

$A$. Oh, when you say "know them," I know them only on a speaking basis, just to say hello, and maybe call them by their name, and they maybe know me by name; l'd say several dozen, I'd say, around the Civic Center here.

Oh, some of them were working inside the Courthouse building, men that I would see almost daily, and others would be working around as gardeners, around the Civic Center.

$Q$. Then are the persons that you said that you know with Spanish surnames, are these persons that worked around and inside the Courthouse?

A. Both in and around the Courthouse area. ${ }^{73}$

Judges Call and Schweitzer did not hesitate to claim to know persons with Spanish surnames. Indeed, they initially claimed to know many. Nevertheless, they could not actually recall the name of even one MexicanAmerican acquaintance. There is little reason to include excerpts from the testimony of other judges, because all answered to more or less the same effect: They could never name more than one or two Mexican Americans, and even then, they frequently named gardeners or servants. ${ }^{7 s}$ The judges made a practice of nominating persons to serve as grand jurors from within their social circles, yet few Mexican Americans moved within those bounds.

73. Transcript, supra note 8, at 310-11, 316.

74. Consider the following exchange between Acosta and Judge Samuel Grenfield:

$Q$. Do you know any Spanish-sumamed persons in Los Angeles County?

A. One or two.

$Q$. Are these persons friends of yours?

A. No, they are domestics.

$Q$. Do they work as domestics for you, or for other people?

A. For us.

Q. Do you know any other Spanish-surnamed persons other than these two?

A. That is, I personally know them, is that what you are asking?

$Q$. Well, yes, your Honor.

$A$. The answer is no.

Id. at 722; see also id. at 419 (testimony of Judge George A. Dockweiler) (“'The only MexicanAmerican man I know is the man who runs the gasoline station at Larchmont and First Sirect. He is of Mexican extraction."). 


\section{E. Extraracial Discrimination}

Of course, others besides Mexican Americans lived beyond the circle of the judges' familiarity. As one would expect, numerous social biases informed the jury nomination process. Consider in this context the testimony of the 1966 Los Angeles County grand jury foreman, Averill Munger, describing to a legislative committee on grand jury reform his elevation to that post:

Munger. [W] hen our group of $23 \ldots$ became jurors, then the presiding judge of the Superior Court, Judge Nix, last year, and Judge Alarcon, the criminal calendar judge, presiding judge of the criminal calendar court, those two men called four or five of the male jurors, and there were only, I think, nine of us. We were outnumbered by women for the first time in the history of the grand jury. At any rate, these two men picked four or five of us who they thought might be good foremen, and we were interviewed in the judges' chambers.

[Committee Chair] McMillan. They didn't think any women would make good foremen?

Munger. Well, evidently not. Actually, when I was appointed the judge asked me if I belonged to any group that threatened a change in our government, and I said, yes, I did-I belonged to the Republican Associates, and I guess with Judge Nix being a strong Republican, they made me foreman. So that's how I became foreman. $^{75}$

As in so many places, the dryness of the transcript leaves us wondering. In what tone did Munger relate the easy exclusion of women from consideration as jury foreman? How long was the pause between Munger's "evidently not" and his "Actually,..." and on to the next subject? The tone and the pause might help us to understand whether the exclusion of women troubled Munger, or seemed to him insignificant. But perhaps we can simply infer a light tone and a short pause, for up until this century, women were routinely excluded from positions of public office, including juries, "because of a defect of sex," as Blackstone explained. ${ }^{76}$ And through this century, such discrimination has continued in subtle, seemingly natural ways. ${ }^{77}$ Among the judges, as apparently for Munger, women seemed to warrant diminished confidence as a matter of routine.

75. EFFICIENCY AND ECONOMY, supra note 62, at 59-60 (testimony of Averill Munger).

76. FRANKEL \& NAFTALIS, supra note 38 , at 34 (quoting Blackstone).

77. The first case to hold squarely that the exclusion of women from jury venires violated the Constitution did not come until Taylor v. Louisiana, 419 U.S. 522 (1975). In that decision, eight justices reasoned that "the fair-cross-section requirement is violated by the systematic exclusion of women.... [A] flavor, a distinct quality is lost if either sex is excluded." Id. at 531-32 (citations omitted). Justice Rehnquist entered the lone dissent, chastising the majority because 
Notice also Munger's elevation to grand jury foreman seemingly by virtue of his Republican credentials, so wittily invoked. The close juxtaposition of the way Munger benefited from gender and political party affiliation usefully demonstrates the range of social norms implicated in the judges' selection of grand jurors. Some of the norms relied upon, such as those involving race and gender, drew on what we now regard as among the most injurious myths of difference. Others, such as party affiliation or country club membership, seem by current standards only moderately pernicious. And still others, such as class and profession, currently seem to lie somewhere in-between. Yet all operated to skew the distribution of grand jurors away from one reflecting a cross section of the community. The discrimination apparent in the judges' selection practices favored a narrow group of people, and excluded many, many more. Though the favored group supposedly represented the population as a whole, it instead reflected one version of the elite, a group of people on the higher rungs of a host of social hierarchies. ${ }^{78}$

\section{F. Discrimination by the Numbers}

To gain a clearer perspective on the extent of the exclusion of Mexican Americans, consider Table 1. In doing so, keep in mind that Mexican Americans constituted approximately ten percent of the population of Los Angeles County in 1960, and just over eighteen percent in $1970 .^{79}$

\footnotetext{
"this 'flavor' is not of such importance that the Constitution is offended if any given petit jury is not so enriched. This smacks more of mysticism than of law." Id. at 542 (citation omitted).

78. A more exact sense of the skew in typical grand juries emerges from a study of their operation in Alameda County, which includes Oakland, over the 11 years from 1959 to 1969. See Prahl, supra note 40 . The study's findings include the following: Judges nominated men ahead of women, and Republicans over Democrats, by a ratio of seven to three in both cases. See id. at 640. Judges nominated Whites more often than Blacks. Asians. Mexican Americans, and Native Americans combined by almost nine to one. See id. Judges nominated persons over 50 at four times the rate of persons under that age; persons with some higher education over persons with a secondary education or less by a margin of seven to two; and persons with an annual income of $\$ 12,000$ or more ahead of persons with an annual income of $\$ 10,000$ or less at a rate of nine to one. See id. Finally, more than half of the Republican grand jurors knew more than six other grand jurors from other panels, and $30 \%$ of the Republicans knew between 11 and 30 other grand jurors. See id. at 641. Out of Alameda's total population, those selected to serve as grand jurors constituted a very small group of people, many if not most of them friends or friends of friends.

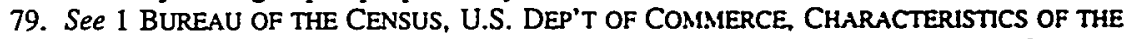
POPULATION 6-24 tbI.7 (1963); BUREAU OF THE CENSUS, U.S. DEP'T OF COMMERCE, COUNTY AND CITY DATA BOOK, 1972, at 16-32 tbl.2 (1973); BUREAU OF THE CENSUS, U.S. DEP'T OF COMMERCE, PERSONS OF SPANISH SURNAME, at 195 tbl.15 (1963).
} 


\section{TABLE 1. PARTICIPATION OF SPANISH-SURNAMEd PERSONS ON LOS ANGELES COUNTY GRAND JURIES, 1959-1969}

\begin{tabular}{|c|c|c|c|c|}
\hline Year & $\begin{array}{c}\text { Total } \\
\text { Nominations }\end{array}$ & $\begin{array}{c}\text { Number of } \\
\text { Spanish- } \\
\text { Surnamed } \\
\text { Nominees }\end{array}$ & $\begin{array}{c}\text { Number of } \\
\text { Grand Jurors }\end{array}$ & $\begin{array}{c}\text { Number of } \\
\text { Spanish- } \\
\text { Surnamed } \\
\text { Grand Jurors }\end{array}$ \\
\hline 1959 & 132 & $1(0.8 \%)$ & 19 & 0 \\
\hline 1960 & 146 & $2(1.4 \%)$ & 19 & 0 \\
\hline 1961 & 148 & $3(2.0 \%)$ & 19 & 0 \\
\hline 1962 & 144 & $4(2.8 \%)$ & 19 & 0 \\
\hline 1963 & 140 & $5(3.6 \%)$ & 19 & 0 \\
\hline 1964 & 155 & $7(4.5 \%)$ & 23 & 0 \\
\hline 1965 & 152 & $6(3.9 \%)$ & 22 & $2(9.1 \%)$ \\
\hline 1966 & 162 & $5(3.1 \%)$ & 23 & 0 \\
\hline 1967 & 151 & $4(2.6 \%)$ & 24 & $1(4.2 \%)$ \\
\hline 1968 & 171 & $3(1.8 \%)$ & 23 & $1(4.3 \%)$ \\
\hline 1969 & 189 & $7(3.7 \%)$ & 23 & 0 \\
\hline TOTAL & 1690 & $47(2.8 \%)$ & 233 & $4(1.7 \%)$ \\
\hline
\end{tabular}

Source: Edward A. Villalobos, Comment, Grand Jury Discrimination and the Mexican American, 5 LOY. L.A. L. REv. 87, 109-10 (1972).

Stark numbers buttress Acosta's charge that the judges of the Los Angeles superior court discriminated against Mexican Americans in the nomination of grand jurors. In the eleven years between and including 1959 and 1969, Los Angeles superior court judges made 1690 grand juror nominations, but the number of nominated Mexican Americans totaled only forty-seven. Of these, a single judge nominated twelve. ${ }^{80}$ Thus, Mexican Americans constituted less than three percent of the grand jury nominations, and if the actions of a single judge are set aside, the percentage drops to no more than two percent. The number of Mexican Americans actually seated as grand jurors is even more dismal. Members of this community constituted only four of 233 grand jurors in the years between 1959 and 1969; that is, they constituted no more than 1.7\% of all grand jurors in that period. If one assumes that Mexican Americans constituted on average fourteen percent of the population of Los Angeles County during this period, they were underrepresented on Los Angeles grand juries by a ratio of eight to one. ${ }^{81}$ Put another way, during the 1960 s,

80. See Edward A. Villalobos, Comment, Grand Jury Discrimination and the Mexican American, 5 LOY. L.A. L. REV. 87, 109 (1972).

81. According to one study of grand jury discrimination. "The principles espoused by both judges and mathematicians would indicate that a long continued disparity of 3:1 or more between the percentage of minority grand jurors and the minority group percentage of the community 
Mexican Americans counted for one of every seven persons in Los Angeles, but only one of every thirty-six nominees and one of every fiftyeight grand jurors. It seems safe to assume that prior to the 1960 s, the exclusion of Mexican Americans was even greater. ${ }^{52}$ These numbers bespeak discrimination, whether or not as a result of the conscious decision of any individual judge. ${ }^{83}$

\section{G. Jury Discrimination and the Southwestern Justice System}

In 1970, the United States Commission on Civil Rights published a report entitled Mexican Americans and the Administration of Justice in the Southwest. ${ }^{84}$ As part of this study, the Commission engaged California Rural Legal Assistance, a legal aid organization, to study grand juror selection across the twenty California counties with the largest MexicanAmerican populations. ${ }^{85}$ The CRLA study confirmed the claims of Acosta and the East LA 13 and Biltmore 6 defendants that Los Angeles County substantially excluded Mexican Americans from grand jury service. ${ }^{86}$ The study also found similar manners and levels of discrimination across the twenty counties examined: "Generally speaking, the judges nominate as grand jurors those whom they or other prominent persons they know deem qualified. As a result, the racial, ethnic, social and economic composition of grand juries in California is limited by the acquaintanceship of the superior court judges." 87 And "in every county studied, the percentage of the minority group grand jurors was significantly less than the minority group percentage of the general population, the disparity varying from substantial in the best counties to grotesque in the worst." 88

The discrimination against Mexican Americans evident in East LA 13 and Biltmore 6 was not unique. Rather, the CRLA grand jury study indicated that nearly every superior court judge in California nominated

raises a presumption of unconstitutional selection. A 3:1 disparity is 'very decided." CRLA Grand Jury Study, supra note 39, at 115.

82. A study of the Los Angeles grand jury published in 1945 noted that "[a]s far as the writer was able to discover no Mexicans have ever been chosen for jury duty." Edwin M. Lemen. The Grand Jury as an Agency of Social Control, 10 AM. SOC. REv. 751.753 (1945).

83. Consider the Supreme Court's pronouncement in Hertandez v. Texas:

Circumstances or chance may well dictate that no persons in a certain class will serve on a particular jury or during some particular period. But it taxes our credulity to say that mere chance resulted in there being no members of this class among the over six thousand jurors called in the past 25 years. The result bespeaks discrimination. whether or not it was a conscious decision on the par of any individual jury commissioner.

347 U.S. 475,482 (1954).

84. U.S. COMM'N ON CIVIL RIGHTS, MEXICAN AMERICANS AND THE ADMINISTRATION OF JUSTICE IN THE SOUTHWEST (1970).

85. See CRLA Grand Jury Study, supra note 39, at 112.

86. See id. at 123-24.

87. Id. at 114.

88. Id. at 119. 
friends and acquaintances to, and routinely excluded Mexican Americans and other minorities from, grand jury service. Moreover, such routine mistreatment overflowed the narrow sphere of grand jury nominations and spread throughout the whole judicial system. Thus, the U.S. Commission on Civil Rights report located grand jury discrimination within a larger pattern of discrimination against Mexican Americans in the administration of justice. The report's findings demonstrated that the justice system throughout the Southwest replicated the substantial mistreatment of Mexican Americans evident in the grand juror selection practices of the Los Angeles superior court judges. ${ }^{89}$

\section{H. Nondiscrimination}

The exclusion of Mexican Americans from California grand juries, whether in the 1960 s or today, may seem relatively minor when considered against the weight of all discriminations suffered by minority communities, and so it is.$^{90}$ Nevertheless, such exclusion is far from trivial, especially to the extent that it reflects, as this Article argues it does, ubiquitous forms of institutional racism. Even on its own terms, however, the social importance of nondiscrimination in the empanelment of grand juries can be measured on ideal, pragmatic, and symbolic levels.

\section{Ideals}

Nondiscrimination is a deeply embedded ideal in our society, one long extolled as an essential if often imperfectly realized feature of the grand jury system. In 1970, the Supreme Court wrote,

89. The Commission's report recorded the following problems. In the interaction between the police and the members of Mexican-American communities: (1) incidents of excessive police violence; (2) discriminatory treatment of juveniles; (3) discriminatory enforcement of motor vehicle ordinances; (4) excessive use of "stop and frisk" techniques and "investigation" arrests: (5) general discourtesy; and (6) instances of law-enforcement interference with "Mexican American organizational efforts aimed at improving the conditions of Mexican Americans in the Southwest." U.S. COMM'N ON CIVIL RIGHTS, supra note 84, at 88. In bail proceedings: (1) application of unduly rigid standards for release of Mexican Americans on their own recognizance; (2) failure to give bail hearings until long after persons were taken into custody; and (3) a practice of "setting of excessive bail to punish Mexican Americans rather than to guarantec their appearance for trial." Id. With respect to juries: (1) failure on the part of judges and jury commissioners to undertake affirmative efforts to obtain a cross section of the community; (2) extensive use of preemptory challenges to remove Mexican Americans from petit juries; and (3) in general, a "serious and widespread underrepresentation of Mexican Americans on grand and petit State juries." Id. Finally, in terms of employment within law enforcement organizations: (1) "neither police departments, sheriffs' offices, nor State law enforcement agencies employ Mexican Americans in significant numbers"; and (2) "[o]ther agencies in charge of the administration of justice-courts, district attorneys' offices, and the Department of Justice-also have significantly fewer Mexican American employees than the proportion of Mexican Americans in the general population." Id. at 89.

90. On contemporary grand juror selection practices, see infra notes 145-151 and accompanying text. 
Whether [grand] jury service be deemed a right, a privilege, or a duty, the State may no more extend it to some of its citizens and deny it to others on racial grounds than it may invidiously discriminate in the offering and withholding of the elective franchise... That kind of discrimination contravenes the very idea of a jury- "a body truly representative of the community ...."9s

For the Court, the grand jury resembles the vote: Both institutions serve democracy, while racial discrimination in either undermines it. In this ideal view, popular self-governance and racial nondiscrimination are inextricably tied together. Thus, on one level, the cherished national ideals of racial nondiscrimination and democracy require efforts to ensure the representation of a cross section of the community on grand juries.92

\section{Pragmatic Concerns}

On a less ideal level, nondiscrimination should govern grand juror selection because grand juries carry considerable civic responsibility. In this context, recall the California grand juries' sweeping responsibility to vote or refuse indictments. Given these powers, the absence of members of the groups most directly affected by the criminal process-the poor, the young, and minorities-raises questions of basic fairness. ${ }^{93}$ More directly, the presence of minorities on the 1968 and 1969 Los Angeles grand juries might have resulted in closer scrutiny of cases such as East $L A 13$ and Biltmore 6.94

Recall also that California required grand juries to investigate and report on county government, including the conduct of public officials and the expenditure of public funds. ${ }^{95}$ As one commentator observed, "In terms of the California grand jury's overall effort ... the indictment function is relatively minor (in some counties, nonexistent) compared to its

91. Carter v. Jury Comm'n, 396 U.S. 320,329 (1970). Carter marks the first time that the Supreme Court recognized the right of potential jurors, rather than defendants, to challenge juryselection practices under the Fourteenth Amendment. See id.

92. Vikram Amar argues at length that "the link between jury service and other rights of political participation such as voting is an imporant par of our overall consututional structure." Vikram David Amar, Jury Service as Political Participation Akin to Voting. 80 CORNELL L. REV. 203, 206 (1995); see also AKHIL REED AMAR. THE BILL OF RIGHTS: CREATION AND RECONSTRUCTION 95 (1998) (noting the historical link between popular participation on juries and self-governance).

93. See FRANKEl \& NAFTALIS, supra note 38, at 98.

94. See CRLA Grand Jury Study, supra note 39, at 113-14.

95. See CAL. PENAL CODE §§ 919(b)-(c), 925, 928, 933 (West 1972). See generally Bruce Trevor Olson, The California Grand Jury: An Analysis and Evaluation of Its Watchdog Function (1966) (unpublished M.C. thesis, University of Califomia (Berkeley)) (on file with the Boalt Hall Law Library). One statute provided that "[ejvery grand jury shall investigate and repon upon the needs of all county officers in the county, including the abolition or creation ... [and] the method or system of performing the duties of, the several offices." CAL. PENAL CODE $\$ 928$. Another required that "[t]he grand jury shall annually make a careful and complete examination of the accounts and records, especially those pertaining to revenue, of all the officers of the county." Id. $\S 925$. 
responsibilities as community watchdog." ${ }^{96}$ Here again, over the years Los Angeles grand juries might have taken different routes had a cross section of the community been on the panels. ${ }^{97}$ Instead, where the grand juries pursued investigations, they seemed content with superficial studies that praised the county's conduct. ${ }^{98}$

Of course, to expect grand jury activism on behalf of minority communities may be to expect too much. In criminal matters, grand juries often serve, at best, as little more than a rubber stamp for the prosecutor and, at worst, as an accomplice in the abuse of power. ${ }^{99}$ In civil matters,

96. Olson, supra note 95, at 3; see also Note, Some Aspects of the California Grand Jury System, 8 STAN. L. REV. 631, 631 (1956) ("Today, the California grand jury typically devotes most of its time not to considering criminal cases but to watching over the needs of the county, the conduct of public officials and the expenditure of public funds."). Los Angeles grand jurics devoted approximately one-third of their time to performing such watchdog functions. See Mar, supra note 48 , at $58-59 \& \mathrm{n} .125$.

97. Concerning the grand juries' general investigative powers, the 1970 CRLA study speculated as follows:

In the course of its general inquiries into governmental affairs, the grand jury could probe into racial or ethnic biases in city and county hiring ... or in the operation of housing projects or other local welfare programs. In monitoring the operations of local government, the grand jury can determine whether all sections of the community are equally enjoying the benefits of such services as police and fire protection, sewer and water lines, sidewalks, streets, street lights, parks, swimming. and other recreational facilities.

CRLA Grand Jury Study, supra note 39, at 113. The U.S. Commission on Civil Rights echoed this sentiment. See U.S. COMM'N ON CIVIL RIGHTS, supra note 84, at 39.

98. Consider a grand juror's description of a study of the county jail system:

The jails committee is a very light and fascinating job. The big duty was to go up to the jail in the Hall of Justice for a beautiful luncheon served on the ladies' side and to be addressed by our sheriff, Peter Pitchess, and others on his staff. Most of the jurors spent their time enjoying the luncheon. Mr. Dunfore, the Chairman, asked me as the secretary to make the report, so I went in the kitchen. The cook said ... no grand jury had ever been in the kitchen, and asked me if I would like to taste the clam chowder. Then I went back and visited the nurse. I examined the medical facilities. I went into the cells. ... I have heard a lot of criticism, but I was very satisfied.

EFFICIENCY AND ECONOMY, supra note 62, at 102 (testimony of Juanita Sayer Erickson, 1962 Los Angeles County grand juror).

99. Consider the following appraisals of grand juries in general: "Day in and day out. the grand jury affirms what the prosecutor calls upon it to affirm-investigating as it is led, ignoring what it is never advised to notice, failing to indict or indicting as the prosecutor 'submits' that it should." FRANKEL \& NAFTALIS, supra note 38, at 22. Or consider the opinion of a judge and former prosecutor on the undue influence of prosecutors over grand juries: "Today, the grand jury is the total captive of the prosecutor who, if he is candid, will concece that he can indict anybody, at any time, for almost anything, before any grand jury." William J. Campbell, Eliminate the Grand Jury, 64 J. CRIM. L. \& CRIMINOLOGY 174 (1973). These general assessments match a 1962 Los Angeles County grand juror's description of the grand jury's indicting function, offered in response to a question about the proportion of cases brought to them by the district attorney that resulted in indictments:

Most of them were indictments, because the evidence was good. These people are not darn fools, especially on a criminal complaint. That's the creme de la creme. They're not dam fools. If the District Attorney or his aides and the law enforcement officials with the Attorney General don't have enough evidence, they are not going to waste our time or theirs. So most of them resulted in indictments.... I call them revolving door cases .... They come in one door and go out the other. they just keep this up. Those were all indictments. What did we know?

EFFICIENCY AND ECONOMY, supra note 62, at 112-13 (testimony of Juanita Sayer Erickson, 1962 Los Angeles County grand juror). 
they perform only a little better. ${ }^{100}$ We should not imagine that the proportional presence of minorities on California's grand juries would significantly impact the way they function, either in the criminal sphere or as community watchdogs. We should, however, expect some effect, even if not a dramatic one.

\section{Symbolic Importance}

Finally, nondiscrimination should prevail in grand juror selection for symbolic reasons as well. Exclusion from organs of self-government communicates an inferior social position, while participation bespeaks full civic membership. Consider the opinion of two Mexican-American law students writing in 1971 on the importance of Mexican-American participation on California grand juries. Not only did "the exclusion of Chicanos from Grand Juries remove[] possible safeguards against misconduct," they wrote, but "misconduct is even encouraged to the extent that the Chicanos are made to appear inferior, alien and legally outcast." ${ }^{101}$ The Supreme Court made a similar point when it wrote in 1970 that " $[t]$ he exclusion of Negroes from jury service because of their race is "practically a brand upon them... an assertion of their inferiority." 102 In contrast, participation signals acceptance. Consider the comment of Lydia López, a 1971 Los Angeles County grand juror from East Los Angeles: "[S]ince I am on the grand jury the people from my area feel they have a voice, they feel terrific about my position." 103

Substantial ideal and pragmatic concerns warrant nondiscrimination in the selection of grand jurors, but the most important reasons for nondiscrimination may well be symbolic. In the context of a society that stereotypes many groups as racially inferior, the equal public representation of such groups may proclaim the falsity of such ideas, both to the group

That grand jurors should defer to prosecutors is not at all surprising; they are laypersons temporarily integrated into a highly professionalized criminal justice system. For a description of how the grand jury's organizational characteristics undermine its independence, sec DEBORAH DAY EMERSON, GRAND JURY REFORM: A REVIEW OF KEY ISSUES 21 (1983). See also Andrew D. Leipold, Why Grand Juries Do Nor (and Cannot) Protect the Accused, 80 CoRNel. L. REV. 260,264 (1995) ("The only issue jurors are asked to decide is whether the prosecutor's evidence is legally sufficient to justify an indictment .... [A]ssigning this role to a jury ... consures that even reasonable, independent-minded jurors will defer to the prosecutor's judgment ....").

100. The most complete study of Califomia grand juries to focus on their civil watchdog function concluded that "the California panel is quite socially passive, rarely exercising its somewhat unusual, and potentially dynamic. powers." Olson. supra note 95. at 226.

101. Lorenzo Arredondo \& Donato Tapia, El Chicano y the Consriturion: The Legacy of Hernandez v. Texas Grand Jury Discrimination, 6 U.S.F. L. REv. 129, 135 (1971). The term "Chicano" is often used to refer to Mexican Americans, especially by politicized members of that community.

102. Carter v. Jury Comm'n, 396 U.S. 320, 329 (1970) (quoting Strauder v. West Virginia. 100 U.S. 303, 308 (1879)).

103. Villalobos, supra note 80 , at 121 n.201. 
members and to the larger society. Full participation, it might be said, would symbolize a new society.

\section{GRAND JURY REFORM}

East LA 13 and Biltmore 6 did not constitute the first attempts to raise the issue of discrimination in the selection of California grand jurors. For example, as early as 1964, the California legislature in hearings on the grand jury system heard the Los Angeles NAACP's legal counsel urge "a better cross section of citizens within the county on the grand jury." 104 Unrepresentative grand juries also attracted attention in 1967, when a legislative committee held a hearing in Los Angeles under the following charge:

We are vitally interested in the selection and composition of county grand juries for the very reason that this is a judicial body and grand jurors are officers of the Superior Court in each county where they serve. Are they selected in a representative fashion so that we can say that they are a random cross-section of this community? Is it equally possible for every eligible citizen-those residents of the county and over twenty-one- to be selected to serve on this august body? Or do only persons of certain backgrounds and upper income levels get nominated? ${ }^{105}$

Thus, problems in the selection of grand jurors, particularly in Los Angeles, appeared on the radar screen well before the East Los Angeles cases. ${ }^{106}$ In this context, despite the defendants' failure to prevail on their equal protection arguments, East LA 13 and Biltmore 6 placed additional pressure on the courts and legislature to reform grand juror nomination practices. In this Part, I consider the limited legislative and judicial reforms regarding grand juror selection undertaken during the early 1970s. Perhaps few will

104. California State legislature Assembly interim Comm. ON Criminal Procedure, Problems of THE CALIFORNIA GRAND JuRY SySTEM 26 (1964) [hereinafter CRIMINAL PROCEDURE] (testimony of Thomas G. Neusome). Neusome added that "[o]n several occasions I have had an opportunity to discuss this matter with the Presiding Judge of the Superior Court in Los Angeles County." Id. The same hearings also generated the following assurances from a Los Angeles County superior court judge:

We have made-I can only tell you this in Los Angeles County-a conscientious effort to see to it that members of various ethnic groups are represented on the grand jury. This year we are especially fortunate in having an outstanding grand jury. We do have one negro on the grand jury, one man of Spanish ancestry, and there were some of Chinese ancestry nominated but, unfortunately, the names were not drawn.

Id. at 39 (testimony of Los Angeles County superior court judge Joseph A. Wapner).

105. EFFICIENCY AND ECONOMY, supra note 62, at 2 (testimony of chair Lester A. McMillan).

106. One author traces the impetus for grand jury reform back to 1963, when the California Assembly passed a resolution calling for the study of whether current selection methods ensured the representation of a cross section of the community on grand juries. See Mar, supra note 48, at 38 (citing H.R. Res. 266 (Cal. 1963)). 
be surprised to learn that instead of heralding a new society, such reforms substantially preserved the old.

\section{A. Legislative Grand Jury Reform}

\section{Pressure for Reform}

As mentioned, during the 1960 s concern surfaced in the legislature over the methods used to select grand jurors. In that decade, legislators introduced perhaps a half-dozen reform bills, although none passed. One commentator's opinion given in 1970 seems broadly applicable: "The bills failed to pass not so much because of active opposition, but because of lack of legislative support for major changes in the grand jury system." 107 Nevertheless, by 1970 the spectacle of the East Los Angeles cases, the striking evidence of Mexican-American underrepresentation in the CRLA study, and the implicit moral condemnation of the U.S. Commission on Civil Rights report increased the pressure on the legislature. Impetus for change came from other sources as well. Several other legal challenges to the grand juror selection system arose, most prominently one launched in defense of Robert Kennedy's assassin, Sirhan Sirhan, in Los Angeles in 1969..$^{108}$ In addition, at least three articles published in California law reviews called for reform. ${ }^{109}$ Finally, the federal government led by example when in 1968 Congress passed the Jury Selection and Service Act, providing that "all litigants in Federal courts entitled to trial by jury shall have the right to grand and petit juries selected at random from a fair cross section of the community." 110

\section{Criminal Grand Juries}

No doubt influenced by these various forces, in 1972 the California legislature passed a version of grand jury reform by giving counties the option to empanel, in addition to a regular grand jury, a second grand jury

107. Id.

108. See People v. Sirhan, 497 P.2d 112 (Cal. 1972); People v. Sirhan, No. A-233421 (Cal. Super. Ct. 1969), discussed in Mar, supra note 48, at 41-43.

109. See Arredondo \& Tapia, supra note 101; Mar, supra note 48; Villalobos, supra note 80.

110. Pub. L. No. 90-274, 82 Stat. 54 (1968) (codified as amended al 28 U.S.C. $\$ 1861$ (1994)). According to the House Committee on the Judiciary, the bill's provisions were intended to "provide the best method for obtaining jury lists that represent a cross section of the relevant community and [to establish] an effective bulwark against impermissible forms of discrimination and arbitrariness." H.R. REP. No. 90-1076 (1968), reprinted in 1968 U.S.C.C.A.N. 1792, 1793. Adding to the weight in favor of reform, in 1970 the National Conference of Commissioners on Uniform State Laws approved a Uniform Jury Selection and Service Act that effectively encouraged all states to model their grand juror selection laws on the federal Jury Selection and Service Act of 1968. See Vincent L. McKusick \& Daniel E. Boxer. Uniform Jury Selection and Service Act, 8 HARV. J. ON LEGIS. 280 (1971). 
limited to handling criminal indictments." jurors for the new "criminal grand jury," the legislature provided that " $[t]$ he presiding judge may select persons, at random, from the list of trial jurors in civil and criminal cases." "Although the act originally mandated random selection, it was made optional as a condition of the bill's passage. $)^{113}$ In effect, reform amounted to allowing counties to seat a second grand jury limited in jurisdiction to criminal matters-and so, directly supervised by the prosecutor's office-with regard to which counties could, if they desired, draw members randomly. ${ }^{144}$ Otherwise, the 1972 reforms required no changes in the grand jury system or the nomination practices of the superior court judges. Existing provisions continued to govern regular grand juries, allowing judges to persist in appointing any otherwise qualified person they wished. ${ }^{115}$

\section{B. Judicial Grand Jury Reform}

Much of the pressure mounting against the legislature to reform the grand jury nomination system acted on the California superior courts as well, though the courts also experienced an additional impetus for reform. Ever greater numbers of superior courts found themselves and their actions under appellate scrutiny in the wake of the East Los Angeles cases.

\section{Early Cases}

Initially, when considering challenges to the personal nomination system employed below, appellate courts sympathized with their judicial colleagues on the lower bench. Or at least the appellate courts' ready acceptance of the trial courts' findings that no discrimination occurred suggests a certain level of uncritical commiseration. Consider a 1970 case involving Black Panther leader Huey Newton. There, an appellate court rejected Newton's challenge to the composition of Alameda's 1967 grand jury, finding that the grand jury was not "constitutionally infirm in any

111. See Cal. Penal Code $\$ 904.6$ (West 1985).

112. Id. $\S 904.6$ (b).

113. See S. 947, 1st Legis. Sess., Cal. Sen. J., June 13, 1972, at 3612.

114. Random selection was made mandatory in 1991. The 1991 amendment added the following subdivision:

It is the intent of the Legislature that all persons qualified for jury service shall have an equal opportunity to be considered for service as criminal grand jurors in the county in which they reside, and that they have an obligation to serve, when summoned for that purpose. All persons selected for the additional criminal grand jury shall be selected at random from a source or sources reasonably representative of a cross section of the population which is eligible for jury service in the county.

CAL. PENAL CODE $\$$ 904.6(e) (West Supp. 1999).

115. Because federal grand juries bear responsibility only in the criminal area, a fair argument can be made that California nearly matched the 1968 federal reforms when it provided for the creation of separate criminal grand juries with potentially randomly selected members. 
respect pertaining to its selection." 116 Or consider that in 1972, an appellate court endorsed the finding that the San Diego County superior court "judges in selecting the nominees for the 1969 grand jury did not discriminate against or exclude any class or grouping of individuals for race, color, age, economic status, education, employment history, and I am including for any reason... They have failed to show any exclusion at all." 117

\section{Biltmore 6}

The 1970 appellate decision in Biltmore 6 started a different trend. ${ }^{118}$ In considering the defendants' equal protection challenge, superior court judge Arthur Alarcon found no statistical evidence of discrimination in the composition of the 1969 Los Angeles grand jury, and so refused Acosta's request to call superior court judges as witnesses. ${ }^{119}$ In response, however, Acosta sought a writ of prohibition to stop the trial until he presented his discrimination claim fully, including evidence obtained through the direct examination of judges who had nominated grand jurors.

Breaking with the pattern established by other appellate courts, Biltmore 6 did not simply adopt Judge Alarcon's finding that no discrimination had occurred. Rather, the appellate court agreed with Acosta that Judge Alarcon's ruling "in effect, permitted [the defendants] to call their judicial witnesses only if the statistical evidence made it unnecessary for them to do so." 120 The court noted that because the issue was exclusion and not proportional representation, Alarcon erred in forbidding the defendants to show discrimination by calling the grand juror selectors to the stand. ${ }^{121}$ The court described the defendants' evidentiary strategy as follows:

What [the defendants] did contend and offered to prove was that the system of nominating grand jurors employed in Los Angeles County systematically deprived eligible members of their class from being considered for grand jury duty. In a nutshell they intended to show that, with very few exceptions, the judges of the respondent court were by reason of birth, education, residence, wealth, social and professional associations and similar factors not acquainted with the qualifications of eligible potential grand jurors

116. People v. Newton, 87 Cal. Rptr. 394. 413 (Cl. App. 1970) (emphasis added).

117. People v. Goodspeed, 99 Cal. Rptr. 696. 704-05 (Ct. App. 1972) (first emphasis added) (quoting the findings of the trial court).

118. See Montez v. Superior Cour, 88 Cal. Rptr. 736 (Ct. App. 1970). In Eass LA 13, the Second District Court of Appeal held for the defendants on their First Amendment claim, and so did not consider their Fourteenth Amendment grand jury challenge. See Castro v. Superior Coun. 88 Cal. Rptr. 500 (Ct. App. 1970).

119. See Montez, 88 Cal. Rptr. at 738.

120. Id. at 739.

121. See id. at 738. 
of petitioners' class and that they did not make an adequate effort to overcome this alleged deficiency. ${ }^{122}$

Although the appellate court rejected the implication that the defendants might succeed in showing "any such thing," 123 the court nevertheless pointedly stated that in seeking to examine the judges in their capacity as grand juror selectors, "petitioners unquestionably were on safe ground." 124 In granting Acosta's request for a writ, the appellate court put superior court judges on notice that they were subject to extensive investigations into their conduct in nominating grand jurors, even to the extent of being forced onto the witness stand.

\section{California Appellate and Federal District Court Oversight}

Biltmore 6 heralded a new approach among appellate courts. For instance, in 1971, in another Black Panther case that effectively reversed the approach taken in Huey Newton's challenge, an appellate court ruled that where superior court judges "constitute[d] themselves collectively as the nominating body" for the grand jury, they must "be made available for examination to determine whether constitutional standards were met." 125 Responding to the contention that dragging judges into the witness box unduly disrupted the business of the trial courts, the appellate court admonished, "If such proceedings become burdensome, the judges are free to return the function [of selecting grand jurors] to the jury commissioner." ${ }^{126}$

Or consider a 1974 decision that strongly criticized the Penal Code sections governing grand juror selection, including by implication the 1972 reforms. The appellate court wrote, "The California Penal Code's flaccid directions for grand jury selection contain no effective assurance of broad socio-economic representation." ${ }^{127}$ Noting that "an unrepresentative grand jury ... is detrimental to community aspirations and incompatible with the egalitarian aims of the Fourteenth Amendment," the court then stated, "When discriminatory methods damage the community ... a representative lawsuit is available to redress the community's wrong. To put the matter concretely, California superior court judges are subject to civil process to compel constitutionally sanctioned grand jury selections." ${ }^{128}$ The appellate court in effect invited civil lawsuits challenging the superior court judges.

122. Id. at 740 .

123. Id. at 740 n.9.

124. Id. at 740 .

125. People v. Wells (Wells I), 98 Cal. Rptr. 1, 7 (Ct. App. 1971).

126. Id.

127. People v. Superior Court, 113 Cal. Rptr. 732,739 (Ct. App. 1974). The court added, "The continued absence of meaningful statutory controls only burdens the courts with repeated attacks on grand jury selection methods." Id.

128. Id. at 976 . 
Within a few weeks of the above decision, when a federal district court upheld the right of plaintiffs to sue the San Francisco superior court for discrimination in the selection of grand jurors, it became apparent that other courts had already been thinking along similar lines. ${ }^{129}$

The San Francisco superior court responded to the federal court's decision by empanelling a criminal grand jury with members selected at random, but did not otherwise alter its practice of personal involvement in the selection of regular grand jurors. A year and a half later, the superior court found itself back in federal court, defending the latter practice. The federal district court rejected the superior court judges' assertion "that the civil investigative grand jury can and should be a so-called 'blue ribbon' panel, chosen from a 'narrower base' defined by more rigorous standards." ${ }^{130}$ Concluding that "[a]lthough there are nebulous references in the affidavits of the defendant judges to a preference for civic experience and education, it is clear that the application of the so-called higher qualifications was done in a completely ad hoc, discretionary manner," 131 the federal court ruled that the personal nomination system violated the Fourteenth Amendment. Following the decision, the San Francisco superior court adopted random selection for all grand juries. ${ }^{132}$

\section{The Limits of Superior Court Reform}

Despite San Francisco's example, the majority of counties avoided wholesale reform in grand juror selection. To be sure, some change occurred. For example, the number of Mexican-American nominees in Los Angeles County went from a low of three in 1968 to seven in 1969, and then to ten, thirteen, and fifteen over the next three years. ${ }^{133}$ And even before the San Francisco case got under way in federal court, the percentage of minorities on grand juries there jumped from 5.3\% in 1970 to $36.8 \%$ in 1971 and $26.3 \%$ in $1975 .{ }^{134}$ Despite these numerical indicators of change, however, reforms seem to have been limited.

129. See Quadra v. Superior Court (Quadra ). 378 F. Supp. 605 (N.D. Cal. 1974).

130. Quadra v. Superior Cour (Quadra II), 403 F. Supp. 486, 496 (N.D. Cal. 1975). The plaintiffs noted that the "defendants [the superior cour judges] have provided no objective statement of the necessary qualifications [and] have merely chosen from among their friends and friends of friends in the guise of applying special qualifications." Id.

131. Id. at 498 .

132. See Quadra v. Superior Court (Quadra III). 411 F. Supp. 451,452 (N.D. Cal. 1976). Random selection, it should be noted, was not the only alternative. The Supreme Court has upheld the imposition of higher qualifications for so-called blue ribbon grand juries. See Fay v. New York, 332 U.S. 261, 270 (1947). The Fourteenth Amendment focuses not on the rigor of the standards, but on the means of their application. In this regard, the cour in Quadra III expressed disappointment that the San Francisco superior court had adopted a system of random selection.

133. See Villalobos, supra note 80, at 109. Despite these increases, Mexican Americans never constituted more than eight percent of the nominees between 1970 and 1972, while their population rose to approximately $18 \%$ of Los Angeles County's total population. See supra note 79 and accompanying text.

134. See Quadra $I I, 403$ F. Supp. at 495 tbl. 
Consider the reform undertaken by Sacramento County. In the wake of press criticism of the "select your friends" system, ${ }^{135}$ in 1968, the Sacramento judges committed to selecting the majority of grand jurors from a list of 100 nominees culled from voter registration rolls. ${ }^{136}$ The judges did not, however, draw nominees from that list at random, but rather by interview. Thus, the judges continued to exercise significant discretion over who served on the grand jury. In the words of one commentator, "[T]he judges often apply the same qualifications in selecting names from the list as they did when nominating on their own." 137 Still, the reform must be counted as something of an improvement. Noting the presence of the first African American on a Sacramento grand jury in over a decade, the same commentator concluded, "At least it is no longer necessary to know a judge in order to be selected to serve on the grand jury in Sacramento County." 138

The scope of actual change also seems limited insofar as some judges apparently adopted the language of reform even in reform's absence. Recall the 1971 appellate decision permitting the Black Panther defendants to call superior court judges to the stand. ${ }^{139}$ This decision required Alameda County judges to testify about their actions of four years earlier, when they had nominated the 1968 grand jury challenged in the case. After hearing their testimony, the trial judge found that no discrimination had occurred, and this ruling was upheld on appeal. ${ }^{140}$ Note, however, how the appellate court summarized the testimony of the superior court judges regarding their 1967 practices:

[V]irtually all of the judges testified that they had personally tried to insure representation of a cross-section of the community, especially in regard to black citizens. Many of the judges testified that they had sought the help of leaders in the black community for that purpose. Almost all of the judges testified that they had acquainted themselves with black citizens in order to insure community representation. ${ }^{141}$

Perhaps the Alameda judges exercised more care in their 1967 nominations than did the Los Angeles judges in the same year. Numbers, however, suggest otherwise. Only four of Alameda County's sixty 1968 grand juror nominees were Black, a proportion of $6.7 \%$ while Blacks constituted $12.4 \%$ of the community. ${ }^{142}$ Moreover, as the CRLA study noted, between 1957 and 1968, Mexican Americans constituted only six of the 228 grand jurors

135. See Mar, supra note 48 , at 46 .

136. See id. at $46-47$.

137. Id. at 47 .

138. Id.

139. See Wells I, 98 Cal. Rptr. 1, 7 (Ct. App. 1971); see also supra notes 125-126 and accompanying text.

140. See People v. Wells (Wells II), 114 Cal. Rptr. 777. 779 (Ct. App. 1974).

141. Id.

142. See Wells I, 98 Cal. Rptr. at 6. 
who served Alameda County. ${ }^{143}$ It seems more likely, then, that by 1971 the Alameda judges had learned to censor testimony about nominating one's friends, and to emphasize instead efforts to search high and low for a cross section of the community. That is, they had learned the language of reform and used it even where no reform had occurred. ${ }^{1+4}$

\section{Grand Juror Selection Practices in 1999}

A still greater reason exists to suspect that there were only limited reforms in the 1970s: the persistence of a functionally similar grand juror selection system in the 1990s. A contemporary survey of the twenty California counties studied by CRLA in its 1970 report reveals that in virtually every one of those counties judges exercise considerable discretion over the nomination of potential grand jurors. ${ }^{1+5}$ To be sure, eleven counties now actively invite citizens to volunteer for grand jury service, for example, by advertising in local papers or by soliciting applications from civic groups. And five counties rely on the petit jury pool, which in turn is randomly drawn from voter registration roles and the California Department of Motor Vehicle lists. ${ }^{1+6}$ Nevertheless, eleven counties, including Los Angeles, continue to rely on judicial nominations. ${ }^{147}$

Much more significantly, however, all but three counties have instituted procedures whereby judges vet potential jurors before admitting them to a small pool from which the grand jury is finally drawn. ${ }^{148}$ Irrespective of

143. See CRLA Grand Jury Study, supra notc 39, at 123 tbl.l.

144. With this example in mind, perhaps we could be forgiven some skepticism conceming Judge Alarcon's finding in Biltmore 6, issued after hearing the testimony of his fellow judges: "The evidence shows that a substantial number of the selectors of the 1969 Los Angeles County Grand Jury took affirmative steps to find eligible and qualified persons identifiable as MexicanAmericans to serve on the 1969 Los Angeles County Grand Jury." Pcople v. Raminez. No. A244906, slip op. at 13 (Cal. Super. Ct. Mar. 31, 1971), guoted in Arredondo \& Tapia, supra note 101 , at 143 .

145. The information provided in this section is detailed in Appendix D.

146. See CAL. CODE CIV. Proc. \& 197 (West 1988 \& Supp. 1999).

147. Los Angeles County accepts applications for grand jury service. However, the superior court does not automatically consider applicants for selection. Instead, according to the Los Angeles grand jury web site,

Each ... applicant is interviewed by a member of the Grand and Trial Jurors Committee. The Judge assigns a qualification rating to each voluntecr interviewed. The volunteers' application forms are then circulated among the superior court judges for possible nomination.

From a final list of persons nominated by the judges, forty names and ten altemates are selected by lottery. After these people have been sereened by law enforcement agencies, a second drawing takes place and the final twenty-threc jurors and four alternates are drawn.

How Is a Person Chosen for the Grand Juñ? (visited Sept. 24, 1999) <htip://wwww.co.la.ca.us/ grandjury>. In short, nomination by a judge continues to be a prerequisite for service as a grand juror in Los Angeles County.

148. The three "exceptions" are Los Angeles. San Bernardino. and Imperial counties. In Los Angeles County, every potential grand juror must be nominated by a judge, although once nominated, actual selection is random. See id. In San Bernardino County. the judges usually name 
whether counties generate the names of potential jurors randomly, by application, or by judicial nomination, almost all counties require judges to screen nominees to establish a restricted group, usually of no more than thirty, from among whom the actual grand jurors are randomly selected. Thus, any movement toward openness in the grand juror selection system over the last three decades has been more than matched by a new and almost uniform practice wherein judges sift and select the narrow set of all potential grand jurors.

The judges' continuing exercise of extraordinary discretion in the nomination of grand jurors suggests a potential for high contemporary levels of discrimination on California county grand juries. In Los Angeles County between 1960 and 1969, Mexican Americans accounted for four of the 214 grand jurors seated, or slightly under two percent of the total. ${ }^{149}$ Have the numbers changed much over three decades? Consider the following table:

TABle 2. PARTICIPATION OF HISPANICS ON LOS ANGELES COUNTY GRAND JURIES, 1990-1999 150

\begin{tabular}{|c|c|c|}
\hline Year & $\begin{array}{c}\text { Number of Grand } \\
\text { Jurors }\end{array}$ & $\begin{array}{c}\text { Number of } \\
\text { Hispanic Grand } \\
\text { Jurors }\end{array}$ \\
\hline 1990 & 23 & 1 \\
\hline 1991 & 23 & 0 \\
\hline 1992 & 23 & 2 \\
\hline 1993 & 23 & 1 \\
\hline 1994 & 23 & 1 \\
\hline 1995 & 23 & 2 \\
\hline 1996 & 23 & 3 \\
\hline 1997 & 23 & 4 \\
\hline 1998 & 23 & 1 \\
\hline 1999 & 23 & 0 \\
\hline TOTAL & 230 & $15(6.5 \%)$ \\
\hline
\end{tabular}

Source: Letter from Gloria M. Gomez, Manager, Juror Services Division, Los Los Angeles County Superior Court (Jan. 14, 2000) (on file with the author).

Mexican-American participation on Los Angeles grand juries more than trebled from the 1960s to the 1990s, from under two to over six

the grand jurors directly. Telephone Interview with Sue Shooie, Court Executive Office and Administration, San Bernardino County (Mar. 9, 2000). Out of the 20 counties surveyed, only Imperial County gives judges no discretion in the selection of grand jurors.

149. See supra Table 1.

150. The numbers reflect racial breakdowns of successive grand juries as determined by the Los Angeles superior court. The use of "Hispanic" is the court's. See also Penelope McMillan, Grand Juries' Racial Makeup Under Challenge, L.A. TIMES, Oct. 12, 1993, at 1. 
percent. But recall that during the 1960s, Mexican Americans accounted for fourteen percent of Los Angeles County's total population, while in the 1990s, Latino/as numbered closer to forty-one percent. ${ }^{\text {ist }}$ Thus, proportional to their presence in Los Angeles County as a whole, Latino/as were excluded from grand jury service by an eight-to-one ratio during the 1960 s, and by six-to-one during the 1990s. The continuing exclusion of this community from grand jury service in Los Angeles County in the last decade almost equals the relatively extreme exclusion of Mexican Americans during the 1960s. What little reform occurred in the 1970s apparently did not endure long enough or reach deep enough to alter the levels of exclusion in the grand juror selection system of the 1990s.

\section{THE LIMITS OF INTENTIONAL DISCRIMINATION MODELS}

Return now to the defendants' arguments in East LA 13 and Biltmore 6. Despite the racial exclusivity of the Los Angeles grand juries, the defendants' jury discrimination claims ultimately foundered on a model of racism that stressed intentional behavior. Intentional action has since emerged as a core concept in equal protection jurisprudence, and in theories of racism more generally. In particular, purposeful action is the defining element in discrimination models employing rational choice theory. In this Part, I review the importance of intent in defeating the Fourteenth Amendment challenge in East LA 13, and then consider intentional racism models recently advanced by law-and-economics scholars.

\section{A. The Centrality of Intent in Discrimination Models}

In the extensive testimony Acosta elicited from the judges, evidence abounded that the judges looked almost exclusively to social acquaintances when nominating grand jurors, and that the judges counted few Mexican Americans among that group. However, such testimony apparently did not trouble the prosecutor too much. In responding to the defendants' equal protection claim, the prosecutor did not ask the judges to clarify their testimony regarding their selection practices, or otherwise seek to recast such testimony in any way. Rather, on cross-examination, the prosecutor asked each judge only whether he had intended to discriminate. The exchange between the prosecutor and Judge Call is typical:

151. See supra note 79 and accompanying text. In 1990. Hispanics constituted $37.8 \%$ of the population of Los Angeles County. See 1990 US Census Data, Dalabase C90STFIA, Los Angeles County (visited Jan. 10, 2000) <http://venus.census.gov/cdrom/lookup/947540548>. In 1999. Hispanics amounted to $43.9 \%$ of the population of Los Angeles. See Counsy of Los Angeles Statistical Data (visited Jan. 10, 2000) <http:/www.co.la.us/statistics.hum>. Given these numbers, it is not unreasonable to assume that on average Latino/as accounted for $41 \%$ of the population of Los Angeles during the 1990s. During the 1960s, Mexican Americans constituted virtually all persons now considered Hispanic in Los Angeles County. while in the 1990s Mexican Americans accounted for $75 \%$ of Los Angeles Hispanics. See 1990 US Census Dasa, supra. 
$Q$. In considering or determining whom you were going to nominate, was it your purpose to deliberately exclude any member of any particular racial or ethnic group?

$A$. Under no condition.

$Q$. And in actually placing in nomination the persons whose names have been mentioned here in court, did you intend to intentionally, arbitrarily, and systematically exclude from Grand Jury service any member of any particular racial or ethnic group?

A. No way at all.

$Q$. Did you nominate those persons whom you did in fact nominate because you felt they were the best qualified to serve?

A. Absolutely. ${ }^{152}$

This brief exchange represents virtually the entire cross-examination of Judge Call. The prosecutor posed these same questions, and few if any others, to nearly every judge, and each answered in nearly exactly the same fashion. ${ }^{153}$

At the end of the testimony of the thirty-three judges called by Acosta, the prosecutor, without presenting evidence of his own, asked the court to dismiss the equal protection challenge. He argued "that the defendants have not sustained their burden of proof to show that there was any purposeful systematic discrimination of persons of Spanish surname in selecting the jury." " 154 He insisted,

There was no evidence at all of any intent on the part of any of the Judges or the Jury Commissioner or anyone else involved in the system of selecting the Grand Jurors in this County, to exclude any

152. Transcript, supra note 8 , at 400.

153. Consider as an additional example the questioning of Judge Rhone:

$Q$. By [District Attorney] Hecht. Your Honor, in determining whom you arc going to approach or solicit as a Grand Jury nominee, did you attach any importance whatsoever to the racial or ethnic background of such person?

A. No, I did not.

Q. In considering whom to nominate for Grand Jury service, was it your purpose to deliberately exclude members of any particular racial or ethnic group?

A. It was not.

$Q$. And by actually placing in nomination those persons whose names have been mentioned here in court as being your nominees over the past 10 years. did you intend to intentionally, arbitrarily, and systematically exclude from Grand Jury service members of any particular racial or ethnic group?

A. No.

Q. Did you nominate those persons whom you did in fact nominate for Grand Jury service because you felt that they were highly qualified to serve in that capacity?

A. That is the only basis that I ever nominated them.

Mr. Hecht. Thank you. I have nothing further.

Id. at $680-81$.

154. Id. at 890 (emphasis added). 
person, or to treat any person differently on account of his race or his ethnic group. ${ }^{155}$

For the prosecutor, intent formed the touchstone of discrimination. ${ }^{156}$

For his part, Acosta disputed the need to prove intentional discrimination, and refrained from claiming that any such animus existed. Instead, Acosta labored to show that the practice of nominating acquaintances itself amounted to a denial of equal protection, regardless of whether the judges had intended to discriminate. Acosta explained,

I am not arguing that the Judges wake up every morning and say, "I'm not going to look for any Mexicans today. I'm not going to submit any Mexican names today."

But the whole question of discrimination is not predicated upon any morality or conscious evil, we are talking about facts, we are talking about the results of a system ....

I'm not saying that the Judges are evil persons by any means whatsoever, and I'm not saying that they are even evil in the sense they don't name nominees of Spanish surname.

What is pathetic, tragic, is that none of them know any of them.

....

Now, since they are nominating their friends, how in the world are they ever going to nominate us since they don't know us? We don't exist. ${ }^{157}$

155. Id. at 909 (emphasis added).

156. To be sure, the prosecutor's emphasis on intent resonated with. though it was not compelled by, a powerful current within equal protection doctrine. Washingıon v. Davis, 426 U.S. 229 (1976), came down eight years after the arguments in East LA J3. Thus. in 1968 it was still a relatively open question whether one had to show an intentional "purpose" to discriminate. Indeed, if anything, the weight of the cases suggested that a showing of "purpose" was not required. Through 1968, several Supreme Court cases concerning grand jury discrimination explicitly rejected an intentional discrimination standard where those responsible for selecting jurors had done so from among personal acquaintances. Thus, in Smith v. Texas, 311 U.S. 128 (1940), the Court held, "Where jury commissioners limit those from whom grand juries are selected to their own personal acquaintance, discrimination can arise from commissioners who know no negroes as well as from commissioners who know but eliminate them. If there has been discrimination, whether accomplished ingeniously or ingenuously, the conviction cannot stand." Id. at 132. Along the same lines, the Cour held in Hill v. Texas. 316 U.S. 400 (1942), that "[d]iscrimination can arise from the action of commissioners who exclude all negroes whom they do not know to be qualified and who neither know nor seek to learn whether there are in fact any ... qualified negroes available for jury service." Id. at 404. And again. in Carsell v. Texas, 339 U.S. 282 (1950), a plurality of the Court held. "The statements of the jury commissioners that they chose only whom they knew, and that they knew no eligible Negroes in an area where Negroes made up so large a proportion of the population, prove the intentional exclusion that is discrimination in violation of ... constitutional rights." Id. at 290 . Of course, as this last quotation demonstrates, intent nevertheless operated powerfully in antidiscrimination law in the years leading up to East LA 13, albeit less powerfully than after Davis. See infra note 415 and accompanying text.

157. Transcript, supra note 8, at 923-24. Acosta also put his argument this way: "I'm not saying they consciously were looking for Whites to the exclusion of the other races, but that just happens to be the case. Judge after Judge after Judge testified that he normally and quite naturally selected and asked his friends." Id. at 913. 
Acosta urged upon the court a model of discrimination that did not turn on intention, purpose, deliberation, or conscious action. He readily conceded that the judges were not engaged in "conscious evil," that they had no formulated intention to discriminate against Mexican Americans. In rejecting the purposeful discrimination model, however, Acosta did not turn to a purely effects-based approach. Rather, he urged the court to identify as discriminatory a system of selecting grand jurors that consistently resulted in the exclusion of Mexican Americans. He argued that the superior court judges systematically (though not purposefully) excluded Mexican Americans because in submitting nominations, they drew on narrow circles of friends and neighbors that did not include members of that community. Acosta urged the court in East LA 13, and subsequently in Biltmore 6, to appreciate that a nomination process in which Mexican Americans "did not exist" amounted to discrimination under the Fourteenth Amendment.

Acosta's argument did not sway those courts, however. When the presiding judge in East LA 13 granted the prosecutor's motion to dismiss the equal protection claim, she cited the lack of any evidence of a "willful or intentional desire" to exclude on the part of her colleagues. ${ }^{158}$ In Biltmore 6, the court reached a similar conclusion, finding no evidence that any judge "consciously, deliberately, [or] intentionally" discriminated against Mexican Americans. ${ }^{159}$ These judges relied on and imposed the model of discrimination urged by the prosecutor, the model that required proof of intentional, purposeful discrimination in order to prevail under the Fourteenth Amendment.

Whether actionable under the Fourteenth Amendment, Acosta correctly described the grand jury nomination process as racially discriminatory. Time after time, each judge "normally and quite naturally selected and asked his friends." ${ }^{160}$ Though in doing so the judges perhaps harbored no consciously formulated purpose to exclude Mexican Americans-or, for that matter, Blacks and other racial groups, the less well-off, or otherwise socially marginal classes-exclusion necessarily followed. Because the judges chose from among their friends, those outside such relatively rarified circles effectively ceased to exist as potential grand jurors. Like those in the

158. Judge Kathleen Parker ruled as follows:

I don't see any evidence of any willful or intentional desire on the part of those that are charged with the responsibility of selecting the Grand Jury to keep persons of Spanish sumame, or Mexican-Americans, from the Grand Jury.

Accordingly, the portion of your motion relating to the selection of the Grand Jury Id. at 1006 .

on the grounds that the Grand Jury is illegally constituted, is dismissed . . . .

159. Judge Arthur Alarcon ruled in part as follows: "No evidence was presented that any Judge of the Los Angeles County Superior Court consciously, deliberately, intentionally or arbitrarily discriminated against persons of the class of persons identifiable as MexicanAmericans in the selection of nominees for the 1969 Grand Jury." People v. Ramirez. No. A244906, slip op. at 11-12 (Cal. Super. Ct. Mar. 31, 1971), quoted in Arredondo \& Tapia, supra note 101 , at 142 .

160. Transcript, supra note 8, at 913 (remarks of Oscar Acosta). 
Mexican-American community, other outsiders may not have been "intentionally and purposefully" excluded, but year after year they were just as surely absent from Los Angeles grand juries.

\section{B. Rational Choice Theories of Discrimination}

If Acosta's argument that the grand juror selection process normally excluded Mexican Americans seems correct, he nevertheless tells us little about the dynamics of the process. How did discrimination arise? Did the judges lie about their intentions? If not, did the judges' lack of familiarity with Mexican Americans as a group matter? Might socially pervasive stereotypes about Mexican Americans have influenced the judges' actions, and if so, how? Institutional analysis answers these questions. To place the answers in context, however, we must first consider rational choice explanations for discrimination. Rooted in a tradition of intention similar to that relied upon by the prosecutors and judges in the East Los Angeles cases, rational choice explanations of racial discrimination struggle to answer the questions raised by the East LA 13 transcript.

Rational choice theory encompasses various ideas and principles. ${ }^{161}$ Nevertheless, the basic claims of rational choice theory may be stated informally as follows: (1) Actors know their interests; (2) actors consciously weigh alternative means of maximizing their interests; and (3) actors act to maximize their interests. ${ }^{162}$ In light of these claims, intent forms a key component. The intentional pursuit of specific results bridges the evaluation of alternatives and the maximization of interests. Rational choice theory strongly presumes that, absent some mistake, actors intend the results of their actions. ${ }^{163}$

Rational choice theorists have advanced several explanations of racial discrimination. Each approach assumes an intent to discriminate but offers a different conception of the ends that discriminators seek to maximize. Two theories have long predominated, the associational and the statistical. Under the associational model, offered more than three decades ago by Gary Becker, people discriminate because they have a "taste" for association or disassociation with some groups. ${ }^{164}$ The simplest and most

161. Rational choice theories, in the plural, might therefore be a more accurate formulation. Given the general nature of the discussion here, however, the singular form suffices.

162. See Donald P. GReen \& IAN ShapiRo. Pathologies of Rational Cholce Theory: A CRITIQUe of APPLiCATIONS IN POLITICAL SCIENCE 17 (1994) ("In sum, rational choice theorists generally agree on an instrumental conception of individual rationality, by reference to which people are thought to maximize their expected utilities in formally predictable ways.").

163. Though intentions are presumed to guide actions, rational choice theorists often read intent from the actions themselves, rather than from other sources, such as an actor's selfreporting. This idea is often expressed as "revealed preferences"; it is also often the subject of criticism. See Amartya K. Sen, Rational Fools: A Critique of the Behavioral Foundations of Economic Theory, 6 PHIL. \& PUB. AFF. 317, 322-24 (1977).

164. GARY S. BECKER, THE ECONOMICS OF DISCRIMINATION 6 (1957) ("If an individual has a 'taste for discrimination,' he must act as if he were willing to pay something. cither directly or in 
widely accepted of the rational discrimination theories, the associational model in effect asserts that people discriminate because they want to. In contrast, the statistical model posits that discrimination is rational when race or other indicia of group identity serve as readily observable markers for characteristics that are relatively more difficult to observe. ${ }^{165}$ Discrimination occurs not because it possesses any independent utility, but because, in the calculus of information-gathering, discrimination is efficient. ${ }^{166}$ These theories, of course, are not mutually exclusive. ${ }^{167}$

the form of a reduced income, to be associated with some persons instead of others."). Becker asserted that racial discrimination is costly, and that a perfect market would drive out discriminators. See id. at 35-37. John Donohue has argued to the contrary, see John J. Donohue III, Is Title VII Efficient?, 134 U. PA. L. REV. 1411 (1986), as has Cass Sunstein, see Cass R. Sunstein, Why Markets Don't Stop Discrimination, SoC. PHIL. \& POL'Y, Spring 1991, at 22. Set also David A. Strauss, The Law and Economics of Racial Discrimination in Employment: The Case for Numerical Standards, 79 GEO. L.J. 1619, 1631-43 (1991). Note that Becker's views accord with a general sense among many social scientists that racism is an aberration. "essentially irrational," and so subject to relatively straightforward eradication. FEAGIN \& FEAGIN, supra note 18 , at 5 .

165. See Edmund S. Phelps, The Statistical Theory of Racism and Sexism, 62 AM. ECON. REV. 659 (1972). The statistical model has gained considerable currency in some circles, where it is referred to as "rational discrimination." For example, Dinesh D'Souza writes.

[T]here are many indications that black cultural pathology has contributed to a new form of discrimination: rational discrimination. High crime rates of young black males, for example, make taxi drivers more reluctant to pick them up. storekeepers more likely to follow them in stores, and employers less willing to hire them. Rational discrimination is based on accurate group generalizations that may nevertheless be unfair to particular members of a group.

DiNESH D'SOUZA, THE END OF RACISM: PRINCIPLES FOR A MULTIRACIAL SOCIETY 24 (1995). Richard Epstein relies on the statistical model in arguing that antidiscrimination laws in the workplace are counterproductive. See RICHARD A. EPSTEIN, FORBIDDEN GROUNDS: THE CASE: AGAINST EMPLOYMENT DISCRIMINATION LAWS 33-35, 40-41 (1992). He also relies on the taste model. See id. at 41-47; see also Richard A. Epstein, The Status-Production Sideshow: Why the Antidiscrimination Laws Are Still a Mistake, 108 HARV. L. REV. 1085 (1995). Robert Cooter modulates Epstein's conclusion through the proposal of various market mechanisms to reduce racial discrimination. See Robert Cooter, Market Affirmative Action, 31 SAN DIEGO L. REV. 133. $138,157,167$ (1994).

166. A more recent version of the statistical model postulates that even where actors believe that underlying group characteristics do not differ, discrimination will occur because "people can distinguish between high- and low-character individuals more accurately when the people being sorted are of a similar cultural type." Bradford Comell \& Ivo Welch, Culture, Information. and Screening Discrimination, $104 \mathrm{~J}$. POL. ECON. 542, 543 (1996). It is important to note the definition of "cultural type" offered: "Cultural type here is interpreted broadly to include groups defined by language, religious belief, ethnic background, race, sex, sexual preference, neighborhood upbringing, schooling, or membership in social organizations." Id. Unlike statistical theory, screening-discrimination theory posits that group identities do not convey but instead occlude information about group members. Just as in the statistical approach, however, information costs render group discrimination efficient. In an earlier version of the same thesis, Cornell wrote that " [i] ronically, this implies that discrimination is not generated by racial bias, but by the inability to 'discriminate' between opportunists and honest people in an unfamiliar population." Bradford Cornell, A Hypothesis Regarding the Origins of Ethnic Discrimination, 7 RATIONALITY \& SOC'Y 4, 8 (1995).

167. Richard Posner employs both the associational and statistical models. He writes, for example, that "[s]ome people do not like to associate with the members of racial. religious, or ethnic groups different from their own and will pay a price to indulge their taste." RICHARD A. POSNER, ECONOMIC ANALYSIS OF LAW 715 (5th ed. 1998). He also postulates,

To the extent that race or some attribute similarly difficult to conceal (sex, accent, etc.) is positively correlated with the possession of undesired characteristics, or 
Two additional rational discrimination theories have been advanced recently in the pages of law reviews: the group-status model and the cooperation-signal approach. In 1995, Richard McAdams proposed the former in the Harvard Law Review, ${ }^{165}$ arguing that group-based discrimination generally, and racial discrimination in particular, can be explained insofar as "individuals who seek to maximize the esteem they receive from others have selfish reasons to contribute to group status" through the celebration or the denigration of others. ${ }^{169}$ Here again, as in the statistical approach, the utility of race discrimination lies in what it achieves for the discriminator-in this case, status. Thus, McAdams encourages us to "understand race discrimination as an especially virulent and pathological form of status production." 170 He suggests that "[d]iscrimination and racist behavior generally are processes by which one racial group seeks to produce esteem for itself by lowering the status of another group." 171

In another recent rational discrimination theory, Eric Posner suggests a cooperation-signal model in a 1998 Journal of Legal Studies article. ${ }^{12} \mathrm{He}$ uses game theory, in particular the repeat prisoners' dilemma, to argue that racial discrimination should be viewed as a form of signaling. ${ }^{173}$ Posner postulates that persons who desire to establish cooperative relations over the medium term ("cooperators" or "high types") seek signals by which to distinguish themselves from persons relatively more interested in short-term returns ("cheaters" or "low types"). ${ }^{174}$ Such signals succeed, according to Posner, only where cooperators can afford to engage in the signaling (because of relatively greater expected medium-term returns), but cheaters

\footnotetext{
negatively correlated with desired characteristics. it is rational for prople to use the attribute as a proxy for the underlying characteristic with which it is correlated ("statistical discrimination").
}

Id. at 725. Kenneth J. Arrow's well-known rational choice article on discrimination similarly draws on both the associational and statistical models. See Kenneth J. Arrow. The Theon of Discrimination, in DISCRIMINATION IN LABOR MARKETS 3, 6, 23-24 (Orley Ashenfelter \& Albert Rees eds., 1973). For an overview of these two theories, see Sirauss, supra note 164, at 1621-23.

168. See McAdams, supra note 35.

169. Id. at 1009 .

170. Id. at 1044 .

171. Id.

172. See Eric A. Posner, Symbols, Signals, and Social Norms in Polirics and the Law, $27 \mathrm{~J}$. LEGAL STUD. 765 (1998).

173. See id at 767-69. The prisoners' dilemma involves a highly stylized interaction between two persons who must decide whether to "cooperate" or "defect." In the typical formulation. if both "cooperate," each receives a midlevel retum. If one "cooperates" but the other "defects," the defector receives a high return but the cooperator receives nothing or a negative retum. If both "defect," both receive nothing or a negative retum, but still more than each would have received had he or she cooperated when the other person defected. An "iterated prisoners" dilemma" involves repeated interactions, allowing an opportunity to extrapolate from past behavior and to signal future behavior. See generally PETER C. ORDESHOOK. A POLTICAL THEORY PRIMER I6480 (1992) (explaining and giving examples of the prisoners' dilemmn and the itcrated prisoners' dilemma). In game theory, variations on this hypothetical interaction abound; Posner's principal variation lies in postulating that actors can signal to one another through cooperation and defection across a range of behavior.

174. Posner, supra note 172 , at 768. 
cannot. ${ }^{175}$ Posner then argues that group discrimination presents the appropriate cost structure to function as an effective signal "[b]ecause members of the out-group have skills and other desirable qualities [such that] refusal to deal with them commercially or socially is costly for a member of the in-group." 176 Thus, he concludes, "[d]iscrimination against members of a minority group can serve as a signal of cooperativeness." 177 To provide a more concrete example, Posner cites antimiscegenation and Jim Crow laws, writing that "[t]hese laws do not so much enforce segregation as constantly remind everyone that everyone else is sending the signal." ${ }^{178}$ Under this approach, then, discrimination against racial minorities amounts to an effort by Whites to indicate their "cooperative" character, at least vis-à-vis other Whites. ${ }^{179}$

\section{Intent in Rational Discrimination Theories}

A number of criticisms can be leveled against each of the above theories, both within and outside the terms of rational choice theory. ${ }^{180}$ Here, however, I focus on a problem common to rational discrimination theories: an inability to account for discrimination that is not intentional. When engaged in discrimination, how many recognize having a "taste" for it, or think that race is a useful proxy in their search for information, or intend to enhance their racial group's standing or signal a low discount rate? Moreover, consider those situations in which people discriminate but

175. See id.

176. Id. at 785 (emphasis added).

177. Id.

178. Id. at 788. Rational choice theorists often purport not to explain just racial discrimination, but rather "discrimination" generally, treating the former as a subset of the latter. Posner follows this trend, suggesting that his theory offers important insights not only into Jim Crow laws and so on, but also into patriotism, McCarthyism, and homophobia. See id. at 791 . Similarly, Becker asserts that his theory explains ' 'discrimination' and 'nepotism' in all their diverse forms." BECKER, supra note 164 , at 3.

179. Posner's terminology of "cooperators" and "cheaters" invites comment. In the context of racial discrimination-where, according to Posner's model, "cooperators" and "high types" discriminate, while "those who fail to discriminate against [minorities] are the "cheaters," Posner, supra note 172, at 787-his labels seem backward. Presumably, Posner would reply that these terms reflect only a preference for cooperators over defectors, perhaps justified by the observation that under game theory, conditions of cooperation maximize the "prisoners"' total utility. Posner might also note that rational choice theorists often employ similar terms. See Cornell, supra note 166 , at 542 . While these factors may have spurred Posner's easy reference to high and low types, such considerations apply poorly to the social world Posner purports to explain. Racism in the United States does not comport with the simple dynamics suggested by a prisoners' dilemma, and so the simple moral judgments generated by the latter ought not to be applied uncritically to the former.

180. For internal critiques, see generally Donohue, supra note 164; McAdams, supra note 35 , at 1036-43; and Sunstein, supra note 164. For external critiques, see RICHARD DELGADO, WHEN EQUALITY ENDS: STORIES ABOUT RACE AND RESISTANCE 27-52 (1999), which postulates the importance of nonmarket forces-for example, human "evil"-in explanations of racial discrimination; and Richard Delgado, Rodrigo's Second Chronicle: The Economics and Politics of Race, 91 MiCH. L. REv. 1183 (1993) (book review), which criticizes Richard Epstein's arguments regarding the inefficiency of Title VII in EPSTEIN, supra note 165. 
do not perceive themselves to be discriminating at all. How can rational choice models that stress conscious intent and strategic action assist us in fathoming discriminatory conduct when people genuinely believe they have no intention to discriminate? This last question may be the most pressing challenge currently facing theories of discrimination, since in today's world unintentional discrimination may exceed the conscious sort in both prevalence and social harm. Richard McAdams in his article on groupstatus production is one of the few rational choice discrimination theorists to recognize the import of such questions. The response he offers, however, serves only to highlight the problem.

To explain unintentional action, McAdams relies heavily on an analogy to the ideology of cartels drawn from the work of Richard Posner. ${ }^{181}$ Before addressing this facet of McAdams's argument, however, a fuller sketch of his theory of discrimination is helpful. McAdams bases his model of racial discrimination on the claim that people actively pursue esteem as a "basic pleasure" or interest. ${ }^{182} \mathrm{He}$ then argues that esteem results in part from group membership, and that individuals enhance esteem by either raising or lowering the status of their group. ${ }^{183}$ Discrimination, according to McAdams, occurs when individuals enhance their status by lowering the position of other groups: "When members of a group pursue the indirect production strategy of lowering the status accorded other traits," he writes, "they engage in "discrimination." 184 For McAdams, racial discrimination amounts to status production: "Discrimination and racist behavior generally are processes by which one racial group seeks to produce esteem for itself by lowering the status of another group." 185

In analogizing racial discrimination to status conflict, McAdams's model is helpful. By focusing on status, McAdams correctly identifies group aggrandizement and denigration as core facets of discrimination,

181. See McAdams, supra note 35, at 1059 (citing Richard A. Posner, The Material Basis of Jurisprudence, 69 IND. L.J. 1, 10 (1993)).

182. Id. at 1020 (quoting GARY S. BECKER, THE ECONOMIC APPROACH to HUMAN BEHAVIOR 145 (4th ed. 1992)).

183. See id. at 1045.

184. Id.

185. Id. at 1044. Notice that such statements imply that all racism takes the form McAdams identifies. To this extent, he seems to fall victim to a tendency in racial theorizing that David Goldberg previously identified, the assertion of a unitary theory of racism:

If commentators have mostly assumed race to have a single transhistorical meaning, so too have they narrowed the concept of racism always to connote the same phenomenon.... I want to insist that there is no generic racism. only historically specific racisms each with their own sociotemporally specific causes. There is no single (set of) transcendental determinant(s) that inevitably causes the occurrence of racismbe it nature, or drive, or mode of production, or class formation. There are only the minutiae that make up the fabric of daily life and specific interests and values, the cultures out of which racialized discourses and racist expressions arise.

David Theo GoldBerg, Racist Culture: PhILOSOPhy AND the POLITICS OF MEANiNg 90 (1993). 
thereby centering needed attention on social hierarchies. ${ }^{186}$ Of course, drawbacks to status models exist. First, such models tend to overemphasize the symbolic aspects of discrimination-those aspects that convey the meaning of social action-and consequently may underemphasize the material conditions of inequality. ${ }^{187}$ Second, analogizing racial discrimination to status may obscure the particularities of race and racism, phenomena that deserve extensive study in their own right. ${ }^{188}$ Nevertheless, McAdams's invocation of status advances our understanding of aspects of racial discrimination. ${ }^{189}$

Still, McAdams's theory of status production encounters the same general problem that all rational discrimination theories encounter when applied. Individuals rarely engage consciously in the complicated calculations specified by such theories-in McAdams's case, the calculus of lowering the status of another group in order to enhance the status of their own group and hence the esteem in which they are individually held. Unlike most rational choice theorists, however, McAdams confronts the problem head-on, acknowledging that few if any actors proceed from a conscious interest in esteem. ${ }^{190}$ Instead, he posits that discrimination can be explained by an interest in status production, coupled with an "ideology" in which discriminators deceive themselves regarding that interest. ${ }^{191}$ "Ideology," then, serves a core role in McAdams's theory of racial discrimination as status production. With it, his theory is generally applicable; without it, McAdams's theory applies only in those rare circumstances where persons consciously pursue status interests through racial discrimination.

186. $C f$. KENNETH L. KARST, LAW'S PROMISE. LAW'S EXPRESSION: VISIONS OF POWER IN THE POLITICS OF RACE, GENDER, AND RELIGION 67-111 (1993) (using a status model to explore the Supreme Court's treatment of race); J.M. Balkin, The Constitution of Status, 106 Y ALE L.J. 2313 (1997) (developing a general model of status subordination); Rachel F. Moran, Bilingual Education as a Status Conflict, 75 CAL. L. REv. 321 (1987) (using a status model to assess conflicts over bilingual education); Reva B. Siegel, "The Rule of Love": Wife Beating as Prerogative and Privacy, 105 YALE L.J. 2117 (1996) (discussing gender discrimination as a form of status hierarchy); Reva Siegel, Why Equal Protection No Longer Protects: The Evolving Forms of Status-Enforcing State Action, 49 STAN. L. REV. 1111 (1997) (discussing gender and racial discrimination as status hierarchy).

187. See, e.g., Balkin, supra note 186, at 2323 ("[A] status hierarchy is sustained by a system of social meanings in which one group receives relatively positive associations and another correspondingly negative associations."); id. at 2327 ("[S]ymbolic struggles are forms of status competition."); see also KARST, supra note 186, at 9-10 ("A group's status in American socicty. like any other cultural creation, is an amalgam of the meanings that Americans assign to membership in the group."). McAdams's article exhibits this tendency, as he largely e(juates status with meaning rather than with material privilege.

188. See, e.g., Balkin, supra note 186, at 2313,2320, 2326, 2349-50 (examining racc, sexual orientation, gender, religion, and nobility as status). To be clear, Balkin does not purport to focus on race. Because McAdams's article examines racial discrimination rather than status in general, his article does not suffer from this tendency.

189. Indeed, like McAdams, I rely on status notions to understand the dynamics of racism. See infra notes 353-356 and accompanying text.

190. See McAdams, supra note 35, at 1060.

191. See id. at 1060-61. 
What are the source and nature of McAdams's theory of ideology? In a section entitled "Using Status Production To Explain Racial Beliefs," he introduces the notion of "ideology" by turning to an article by Richard Posner, The Material Basis of Jurisprudence, published in the Indiana Law Joumal in 1993. ${ }^{192}$ McAdams draws from Posner the notion that certain groups-in Posner's example, cartels or guildsengage in self-deception about their interests and motivations. ${ }^{193}$ The result, argues McAdams, is "[s]elf-interested self-deception": ${ }^{194}$ Groups develop "ideological commitment[s]" 195 that amount to earnestly held but false beliefs that serve their real but unrecognized interests. Applying this to racial discrimination, McAdams conjectures as follows:

Members of Posner's representative guild do not openly declare, even among themselves, that they desire to restrain competition in order to charge higher prices and earn monopoly profits. Similarly, whites never explain their discriminatory behavior as serving the function of status production. Even in the Jim Crow South, whites attempted to justify segregation not by reference to naked selfinterest but by claims that blacks were inherently inferior, that blacks preferred segregation, or that segregation somehow reflected the natural order of things. ${ }^{196}$

McAdams might simply mean that discriminators do not own up to an interest in status production, even though they consciously subscribe to it. But in fact, he seems to mean something different. Using the ideas of "selfinterested self-deception" and "ideological commitments," he seems to claim that discriminators pursue an unrecognized interest in status, rationalized through the ideology of racism..$^{197}$ McAdams thus purports to explain not only discrimination per se, but also the rise and evolution of racism itself. ${ }^{198}$

192. See id. at 1059 (citing Posner, supra note 181).

193. See id. at 1060.

194. Id. at $1059-60$.

195. Id. at 1059.

196. Id. at 1060-61.

197. McAdams writes,

[W] hites are more accurately described as the subset of cartels that Posner calls "guilds," that is, cartels with "social cohesiveness." Bused on a morality cmphasizing loyalty and conformity, these guilds have an "ideology" -a set of beliefs that serves to inhibit free-riding-specifically that blacks tend to be inferior, that whites should not interact with blacks in cerain ways, and that whites must "stick together."

Id. at 1070 (citations omitted). Note that McAdams is not concemed with unintentional discrimination, but rather with action prompted by unrecognized motives. In his account, people are aware of their racial prejudice, but not its role in hiding their unrecognized desire for status enhancement. Nevertheless, at root McAdams here grapples with the same question that lies at the base of unmotivated discrimination, namely, how to explain action that is substantially nonconsciously directed.

198. On this last score, McAdams claims 100 much. The origins of, and continuing impetus behind, racial beliefs in the United States have attracted sustained analyses that highlight disputes over resources and labor, religious conflicts, colonialism, the cultural stress of encountering new 
To square his theory of discrimination with reality, McAdams postulates group dynamics of self-deception among discriminators. But what exactly are those dynamics? How do they function? Under what conditions do they arise, or dissipate? Unfortunately, these are all questions that McAdams does not raise, let alone address. In effect, he postulates a cognitive dynamic, but stops short of explaining its operation. To some extent, we should not be surprised. To explain self-deception, McAdams has to push past the boundaries of rational choice theory. Self-deception, after all, runs afoul of one of the most important tenets of that genre. ${ }^{199}$ To some extent, however, the thinness of his account stems from his decision to draw his notion of ideology from a relatively minor article by Richard Posner that does not seriously grapple with that concept. ${ }^{200}$ Indeed, McAdams recognizes that Posner's article provides a slim base from which to address the complicated question of undirected action when he notes, even in the course of relying on the article, that "[Posner] does not explain how belief distortion occurs." 201 In the end, "self-interested self-deception"

peoples, and the advent of human physical sciences. See, e.g., THEOdORE W. ALLEN, THE INVENTION OF THE WHITE RACE (1994); GEORGE M. FREDRICKSON, WHITE SUPREMACY: A COMPARATIVE STUDY IN AMERICAN AND SOUTH AFRICAN HISTORY (1981); REGINALD Horsman, Race and Manifest Destiny: The ORigins of american RaCial angloSAXONISM (1981); WINTHROP D. JORDAN, WHITE OVER BLACK: AMERICAN ATTITUDES TOWARD THE NEGRO, 1550-1812 (1968); ALEXANDER SAXTON, THE INDISPENSABLE ENEMY: LABOR AND THE ANTI-CHINESE MOVEMENT IN CALIFORNIA (1971); RONALD T. TAKAKI. IRON CAGES: RACE AND CULTURE IN NINETEENTH-CENTURY AMERICA (1979).

199. James Bohman makes a similar critique of Gary Becker's efforts to fashion a comprehensive theory of human behavior from rational choice theory:

$[T]$ he generalization of rational choice models of explanation can be had only by abandoning the intentional assumption: the idea that the theory was supposed to give an account of how reasons cause actions. Instead the theory searches for non-intentional maximizing motives and market mechanisms, making the rationality of actors themselves less and less important as an explanatory condition. The problem is that without these assumptions, there is no reason to explain... choices in terms of expected utility.

James Bohman, The Limits of Rational Choice Explanation, in RATIONAL CHOICE THEORY: ADVOCACY AND CRITIQUE 207, 216 (James S. Coleman \& Thomas J. Fararo cds., 1992).

200. The Material Basis of Jurisprudence is the revised text of a talk Posner gave at Indiana University School of Law on the topic of a perceived decline in the quality of law practice since the days of Benjamin Cardozo. See Posner, supra note 181, at 1 n.*, 30. In the articic, Posner asserts a "fruitful analogy" between the decline of the legal profession and "the decline of medieval craft production," an analogy grounded in the operation and collapse of an "ideology" of production that facilitated cartelization by stressing quality and limits to entry. Id. at 1, II, 1320. Although Posner uses the term "ideology" in the article, he focuses not on ideology per se, but on what he referred to as "the ideology of guild production," id. at 11, or elsewhere, "professional ideology," id. at 3. He does not address the nature or operation of ideology in general; for all that he uses the word "ideology," he might just as well be addressing "guild ethos" or "professional ideals."

201. McAdams, supra note 35, at 1059. Conceding that Posner does not explain the operation of belief distortion, McAdams nevertheless asserts that Posner "invoked [belief] distortion to explain how certain cartels solve collective action problems." Id. (emphasis added). Yet even this is not clearly so. To suppor the above claim. McAdams cites to page 10 of Posncr's article. But that page, like so much of Posner's piece, discusses the role of "moral precepts and values" as well as "social cohesiveness" as mechanisms for establishing informal sanctions. Posner, supra note 181, at 10. It may be that such mechanisms operate at the level of "belief 
functions as an analogy, not as a theory. ${ }^{202}$

McAdams correctly insists on status as a core aspect of racial discrimination. Yet the behavioral theory he relies on, by leading him to stress the conscious pursuit of individual esteem, limits his ability to explain that large class of cases in which persons engage in discrimination but do not understand themselves to be discriminating, let alone indirectly pursuing esteem. By undertaking a rational choice approach to status conflict and discrimination, McAdams runs into a problem common to rational choice theories generally: an inability to explain undirected action adequately. This lacuna is particularly significant for theories of racial discrimination because unmotivated discrimination constitutes a pervasive phenomenon. Although McAdams recognizes this theoretical gap and attempts to fill it, the theory of "self-interested self-deception" he posits remains thin and underdeveloped. ${ }^{203}$ Be that as it may, McAdams's effort to confront undirected discrimination serves as an effective segue to institutional analysis, for such analysis centers on undirected action.

\section{TOWARD AN INSTITUTIONAL APPROACH}

East LA 13 poses the question of how to model conduct by organizational actors that is not motivated by conscious racial antipathy, but that nevertheless produces significant discriminatory effects. Institutional analysis seems able to explain this dynamic, as well as what can be termed "institutional racism" more generally. In this Part, I explore those ideas in Harold Garfinkel's Studies in Ethnomethodology that have most influenced the development of New Institutionalism's premises. ${ }^{204}$ I also place New Institutionalism in the context of other social science theories of behavior,

distortion." But at best this must be inferred from Posner's discussion, as he does not explicitly address this issue.

202. Consider, for instance, the actions of the Los Angeles superior court judges in nominating their acquaintances. A concern for status may indeed have operaled al some level in motivating this behavior, but how? In what way were the judges a cartel? What was their interest in excluding large classes of persons from grand jury service? Why wasn't this interest outweighed by an interest in conforming to legal and professional obligations? By what mechanism did the judges' interest in status come to be sublimated, and into what? Did the judges subscribe to an "ideology" of racial superiority? If so, why look beyond this to an interest in status to explain discrimination? If not, what "ideology" guided their conduct? Did all of the judges subscribe to it? Were enforcement mechanisms used, or even necessary? Note that because McAdams fails to elaborate his notion of "self-interested self-deception." his theory cannot even begin to answer such questions. The simple problem is that McAdams does not tell us how "selfinterested self-deception" works.

203. To repeat, the issue is not McAdams's focus on status itself, but rather the mechanism through which he postulates that status intersects with discrimination. As noted earlier, many theorists focus on status in explaining discrimination. Most do not. however, yoke status competition to a rational choice theory of behavior. See, e.g., ERVING GOFFMAN, STIGMIA: NOTES ON THE MANAGEMENT OF SPOILED IDENTITY 2 (1963) (exploring status differentiation from a social constructionist approach wherein "[t]he routines of social intercourse in established settings allow us to deal with anticipated others without special attention or thought").

204. See GARFINKEL, supra note 15. 
in particular rational choice theory. Finally, I develop the ideas of script and path institutional analysis. This Part lays the groundwork for institutional racism theory.

\section{A. New Institutionalism and Ethnomethodology}

Garfinkel was among the first in sociology to consider the implications of the cognitive revolution for theories of social action. ${ }^{205}$ Writing in the 1960s, Garfinkel advanced two important and interrelated arguments. First, he posited a vision of cognition that broke dramatically with the vision underlying the typical rational actor model. For Garfinkel, cognition typically involved not the purposeful evaluation of interests and the strategic calculation of means, but rather what he termed "practical reasoning," an unremarkable, unconsidered reliance on background rules. Second, Garfinkel argued that individual identity does not exist outside of social interaction, but is instead constituted by it. According to Garfinkel, an actor's familiarity with and reliance on background ruleswhat he termed the "[s]ocially-sanctioned-facts-of-life-in-society-that-anybona-fide-member-of-the-society-knows" ${ }^{206}$-is not only cognitively necessary but also serves to establish the actor's social identity. ${ }^{207}$ New Institutionalism draws on these two arguments in its cognitive and cultural components. Largely as a result of the work of Garfinkel, New Institutionalism has adapted a microsociology of practical reasoning, by which individuals both interact with others according to taken-for-granted patterns and in turn constitute themselves. ${ }^{208}$

\section{Cognition and Rationality}

One appreciates Garfinkel's cognitive claims by examining his approach to rationality. Insofar as he articulated a model of human action wherein actors often follow routines rather than engage in purposeful action, Garfinkel may seem uninterested in rationality as a principal engine of human action. Indeed, one sometimes sees New Institutionalists use such terms as "antirationalist" and "transrationalist." ${ }^{209}$ Such a reading of Garfinkel's work would be misleading, however, for he was supremely

205. Garfinkel's interest in cognition traces back to his involvement in an empincal study of jury deliberations undertaken at University of Chicago Law School. See Clark D. Cunningham. The Lawyer as Translator, Representation as Text: Towards an Ethnography of Legal Discourse, 77 CORNELL L. REV. 1298, 1345 n.111 (1992).

206. GARFINKEL, supra note 15 , at 76 .

207. See id. at 273.

208. See DiMaggio \& Powell, supra note 12 , at 21 .

209. See, e.g., Friedland \& Alford, supra note 13, at 235 ("We argue that the opposition is not between rational and irrational, but between different transrational orders."). 
interested in the operation of what he termed not "rationality," but "rationalities." 210

Garfinkel argued against a contemporary wisdom that contrasted the rationality of science with the nonrationality of daily life. He suggested that in fact almost all social behavior involves some combination of rational activities, understood broadly. ${ }^{211}$ Garfinkel advocated considering the following activities, among others, as "rational": categorizing and comparing; concern for timing, temporal order, and causality; analysis of alternatives and consequences; the pursuit of predictability; the formulation of strategies; and the establishment of procedural rules. ${ }^{212}$ He termed these activities aspects of "practical" reasoning. ${ }^{213}$ Nevertheless, Garfinkel argued that several specific forms of rationality never form part of commonsense behavior: concern for establishing the compatibility of means-ends relationships with the principles of formal logic; emphasis on clarity and distinctness of all elements of the decision-making process for its own sake; and, most importantly, an unwillingness to accept-as bases for action any but such "facts" as conform to scientific findings. ${ }^{214}$ According to Garfinkel, "actions governed by the attitude of daily life are marked by the specific absence of these ['scientific'] rationalities." 215

Contrasting practical and scientific rationalities, Garfinkel noted several differences of great importance concerning doubt, trust, and sensemaking. In effect, he argued that practical reasoning involves reliance on background understandings of the world, as well as on background procedures of knowledge regulation.

\section{a. Doubt}

On the fundamental issue of whether the world is as it appears, Garfinkel noted that the scientific theorist ideally embraces unlimited doubt. ${ }^{216}$ The scientific theorist follows rules of interpretive procedure that,

210. GARFINKEL, supra note 15 , at $262-83$ (examining the rational properties of scientific and commonsense activities). Of course, the study of rationality by Garfinkel and in tum by New Institutionalists differs from that by rational choice theorists. In this regard, consider Herber Simon's summarization of the fundamental difference: " [I]n economics. rationality is viewed in terms of the choices it produces; in the other social sciences, it is viewed in terms of the processes it employs." Herbert A. Simon, Rationaliny in Psychology and Economics, in Rational ChOICE: THE CONTRAST BETWEEN ECONOMICS AND PSYCHOLOGY 25, 26 (Robin M. Hogarth \& Melvin W. Reder eds., 1986). The former is sometimes referred to as "substantive rationality." and the latter as "procedural rationality." Id.; see also JAMiEs G. MARCH. A PRIMER ON DECISION MAKING: HOW DECISIONS HAPPEN 2 (1994).

211. See GARFINKEI, supra note 15, at 262-63.

212. See id. at 263-66. In this discussion Garfinkel draws heavily on the phenomenology of Alfred Schutz. See 2 ALFRED SCHUTZ, The Problem of Rationaling in the Social World, in COLLECTED PAPERS: STUdIES IN SOCIAL THEORY 64, 74-76 (Arvid Brodersen ed., 1964).

213. GARFINKEL, supra note 15, at 273.

214. See id. at $267-68,270$.

215. Id. at 270 (emphasis omitted).

216. See id. at 272 . 
in principle, insist on empirical testability and confirmation, holding socially sanctioned beliefs irrelevant. ${ }^{217}$ Garfinkel recognized, of course, that no person functions entirely free of social influences. Nevertheless, he noted that under some circumstances persons adopt a skeptical and empirical attitude toward knowledge. In contrast to this scientific attitude, Garfinkel argued that a "practical" reasoning approach does not and cannot emphasize doubt, but rather emphasizes the ready acceptance of the world as it appears. According to Garfinkel, daily life requires, if one is to act efficiently and normally, the exercise of only limited doubt regarding whether the world is as it seems. "Doubt for the practical theorist is limited by his respect for certain valued, more or less routine features of the social order as 'seen from within,' that he specifically does not and will not call into question"; it is limited by "practical considerations." ${ }^{218}$ In suspending doubt, the practical theorist must accept large amounts of the social world in an unquestioning manner: " $[R]$ outine features of the social order . . . will not [be] call[ed] into question." ${ }^{219}$ Peter Berger and Thomas Luckmann express a similar idea:

The reality of everyday life is taken for granted as reality. It does not require additional verification over and beyond its simple presence. It is simply there, as self-evident and compelling facticity. I know that it is real. While I am capable of engaging in doubt about its reality, I am obliged to suspend such doubt as I routinely exist in everyday life..$^{220}$

Routine features of the social world operate as a set of understandings that people at once rely on and are unaware of in the efficient conduct of everyday life; they are so widely accepted as to be by and large unnoticed as anything other than reality.

\section{b. Trust and Sense-Making}

In addition to drawing on an uncritical acceptance of the social world, practical reasoning, according to Garfinkel, draws on standard unexamined procedures for knowledge regulation. To prove the prevalence of such knowledge rules, he purposefully set out to violate some of them. In one experiment, he demonstrated the tendency of people to enter into conversations with an attitude of trust; in another, he showed the extraordinary lengths individuals go to in order to render meaningful otherwise meaningless communication.

217. See id. at $272-73$.

218. Id. at 273 .

219. Id.

220. BERGER \& LUCKMANN, supra note 14 , at 23. 
Garfinkel argued that individuals conduct everyday affairs according to a rule of trust in relations with others, where to act otherwise - that is, with distrust-requires justification, and if none is forthcoming, results in hostility and ostracism. To demonstrate this, Garfinkel requested his students deliberately to display distrust in situations in which "anyone could see" distrust was not warranted-for example, in asking directions."21 He noted that many students who displayed distrust reported "that the other person was angry with them and hated them." 222 At the same time, test subjects experienced the students' distrust of them as a form of anger: " $[\mathrm{M}]$ any victims ... complained that the student had no reason to be angry with them." ${ }^{223}$ Even after the experiment was over, attempts at conciliation and explanation often failed, leading to "frank displays of anger and 'disgust." ${ }^{224}$ Trusting others, or more specifically, trusting that others will act in accordance with taken-for-granted social norms, Garfinkel concluded, constitutes a virtual requirement in the conduct of everyday life.

Garfinkel also postulated that actors rely on a knowledge rule whereby the great bulk of communication is presumed to be meaningful-that is, presumed to possess a readily intelligible substantive content. He brought the operation of this rule to the foreground in an experiment that recruited undergraduate students to participate in "evaluating" a new studentcounseling method. Garfinkel asked the recruited participants to describe their concerns to a "counselor" and then to pose questions susceptible of a "yes" or "no" answer. Unknown to them, the "counselors" were given a prewritten list of random yeses and noes with which to respond to each question. In a remarkable display, the student subjects easily carried through with the exchanges - asking a series of questions, reading into the "answers" detailed substantive content, actively responding to the supposed content by formulating new questions, rationalizing seeming contradictions, and searching for and constructing patterns. ${ }^{23}$ Moreover, subsequently asked to evaluate the exchanges, all students directed their comments to the "advice that they had been given," demonstrating their perception that the "answers" received had not been random words but considered responses to their questions. ${ }^{226}$

221. GARFINKEL, supra note 15 , at 51 .

222. Id.

223. Id.

224. Id. at 52.

225. See id. at 79-94. Of course, as one of my colieagues noted, it might be that college students are especially likely to attempt to render sensible the senseless.

226. Id. at 89. As one student commented.

The answers I received I must say that the majority of them were answered perhaps in the same way that I would answer them .... One or two of them did come as a surprise to me and I felt that the reason perhaps he answered these questions the way he did is for the reason that he is not aware of the personalities involved ... I was interpreting his answers even though they were yes or no answers as fully meditating over these situations that I presented to him and they had a lot of meaning to me. Id. at 84 . 
According to Garfinkel, the practical theorist not only accepts that the world is as it appears, but also assumes that it "makes sense." For the practical theorist, the world known in common is sensible and to be trusted as such.

\section{c. Rules and Rationalities}

Garfinkel claimed that in their daily lives actors draw upon background knowledge and rules of knowing. He did not postulate, however, that social actors act irrationally. On the contrary, rationalities play an integral part in his model, though these rationalities operate in conjunction with largely unexamined but indispensable background understandings of the world and rules of appropriate engagement. ${ }^{227}$ For Garfinkel, unstudied beliefs and rules and the exercise of rationalities did not represent antithetical or independent modes of thought, but rather parts of a cognitive whole:

In the conduct of his everyday affairs in order for the person to treat rationally the one-tenth of this situation that, like an iceberg appears above the water, he must be able to treat the nine-tenths that lies below as an unquestioned and, perhaps even more interestingly, as an unquestionable background of matters that are demonstrably relevant to his calculation, but which appear without even being noticed. ${ }^{228}$

The model of social action that Garfinkel posited depicts persons not as automatons jerked about by forces beyond their conscious control, but as accomplished actors repeating motions made a thousand times before, relying on a set of well-honed moves to achieve familiar goals. For the actor, unlike the automaton, not only routines but also rationalitiestemporal sequencing, consequential reasoning, goal direction, and so onare integral to action. At the heart of New Institutionalism's cognitive claims rest Garfinkel's insights regarding the necessity of background understandings and rules that serve as unseen antecedents to rational action.

\section{Culture}

Garfinkel's focus on attitudes toward knowledge directly raises the issue of socialization. The practical theorist, he suggests, relies on the "natural facts of life" not simply as a matter of convenience, but in order to

227. In this way, the opposition often postulated in cognitive psychology between "motivational" and "cognitive" impulses to action posits too stark a dichotomy. See. s'.g.. Linda Hamilton Krieger, The Content of Our Categories: A Cognitive Bias Approach to Discrimination and Equal Employment Opportunity, 47 STAN. L. REV. 1161, 1164 (1995).

228. GARFINKEL, supra note 15 , at 173. 
establish standing as a bona fide member of the social group. ${ }^{229}$ Herein lies the basis for New Institutionalism's cultural claims.

\section{a. The World in Common}

Garfinkel argued that social membership depends upon the practical actor participating in a common intersubjective world marked by accepted rules of conduct. ${ }^{230} \mathrm{He}$ claimed that at the very core of social relationships exists a body of knowledge-a set of interpretive rules, repertoires of appropriate actions, and so on-that all social actors must share to be regarded as "normal" or unquestioned members of the community. On this level, taken-for-granted aspects of social interaction serve not merely as cognitive tools, but as cultural codes: They bear not just the normative force of something one should do, but also the moral force of something that anyone sane and decent must do. "A society's members encounter and know the moral order as perceivedly normal courses of action-familiar scenes of everyday affairs, the world of daily life known in common with others and with others taken for granted." ${ }^{231}$ One must conform, one does conform, but rarely as a matter of thoughtful choice. Actors conform because received rules and understandings define, on a preconscious level, the way the world is and ought to be. ${ }^{32}$ For the practical theorist, the unthinking acceptance of and reliance on the "natural facts of life" not only facilitate interaction with others but also serve as strict requirements for membership in normal, sane society. ${ }^{233}$

229. Id. at 275.

230. See id.

231. Id. at 35. In contrast, under the forms of scientific ratuonality noted above, an investigator is obligated to "know" only what she has decided to give credence to; ideally, such credence is given independently of the status of others sharing or disclaiming such knowledge. See id. at 75 .

232. Berger and Luckmann emphasize this point:

Since [the sum total of "what everybody knows"] is socially objectivated as knowledge, that is, as a body of generally valid truths about reality. any radical deviance from the institutional order appears as a departure from reality. Such deviance may be designated as moral depravity, mental disease, or just plain ignorance.... In this way, the particular social world becomes the world tour courn.

BERGER \& LUCKMANN, supra note 14, at 62.

233. Notice that culture not only transmits but also is partially produced by institutions. Groups not only engage in but also rework such received understandings, in tum reconstituting culture. As Berger and Luckmann put it.

[Tt is important to emphasize that the relationship between man, the producer, and the social world, his product, is and remains a dialectical one. That is, man (not, of course, in isolation but in his collectivities) and his social world interact with each other. The product acts back upon the producer.

Id. at 57 . "Knowledge about society is thus a realization in the double sense of the word, in the sense of apprehending the objectivated social reality, and in the sense of ongoingly producing this reality." Id. at 62. 


\section{b. Identity}

Garfinkel also argued that when individuals draw upon a common world, doing so constitutes them as individuals. In conforming to socially required background rules of knowledge and communication, individuals not only establish membership in a common culture, but also take on an identity. ${ }^{234}$ For the practical theorist, the "natural facts of life" constitute the locus of knowledge, at the same time that subscription to and participation in the replication of such "facts" constitute the self. Social actors do not exist outside of or independent of the social context in which they find themselves. Instead, the identity of social actors, including aspects of character such as race, class, and gender, but also their interests and preferences, arises through reliance on unexamined practices and routines. ${ }^{235}$ New Institutionalism insists on the constitution of individuality through social interaction. ${ }^{236}$

\section{B. New Institutionalism and Social Science Theories of Behavior}

New Institutionalism's cognitive and cultural components not only define that school, but also can be used to locate it with respect to other social science theories of behavior. Its component claims translate into axes along which such theories may be placed, with a cultural axis measuring postulated degrees of social construction and a cognitive one comparing posited levels at which action is directed. Employing such axes renders a rough graph, with New Institutionalism and rational choice theory in opposite quadrants. Although this graph overstates the differences between various theories and simultaneously understates the degree of variation within each approach, it nevertheless constitutes a useful device for highlighting the relationship between competing conceptions of social action. ${ }^{237}$

234. See GARFINKEL, supra note 15 , at 281 .

235. Aaron Wildavsky addresses the impact of institutions on preference formation in Aaron Wildavsky, Choosing Preferences by Constructing Institutions: A Cultural Theory of Preference Formation, 81 AM. POL. SCI. REV. 3 (1987).

236. See DiMaggio \& Powell, supra note 12, at 21; see also John W. Meyer et al., Ontology and Rationalization in the Western Cultural Account, in INSTITUTIONAL STRUCTURE: CONSTITUTING STATE, SOCIETY, AND THE INDIVIDUAL 12 (George M. Thomas et al. eds., 1987) ("[I]nstitutionalized cultural rules define the meaning and identity of the individual and the patterns of appropriate economic, political, and cultural activity engaged in by those individuals.").

237. Ronald Jepperson uses a similar matrix, though with one axis scaled to the level of social construction and the other to the level of analysis, individualist or structuralist. See Jepperson, supra note 16, at 154. 
GRAPH 1. A COMPARISON OF SOCIAL SCIENCE THEORIES OF BEHAVIOR

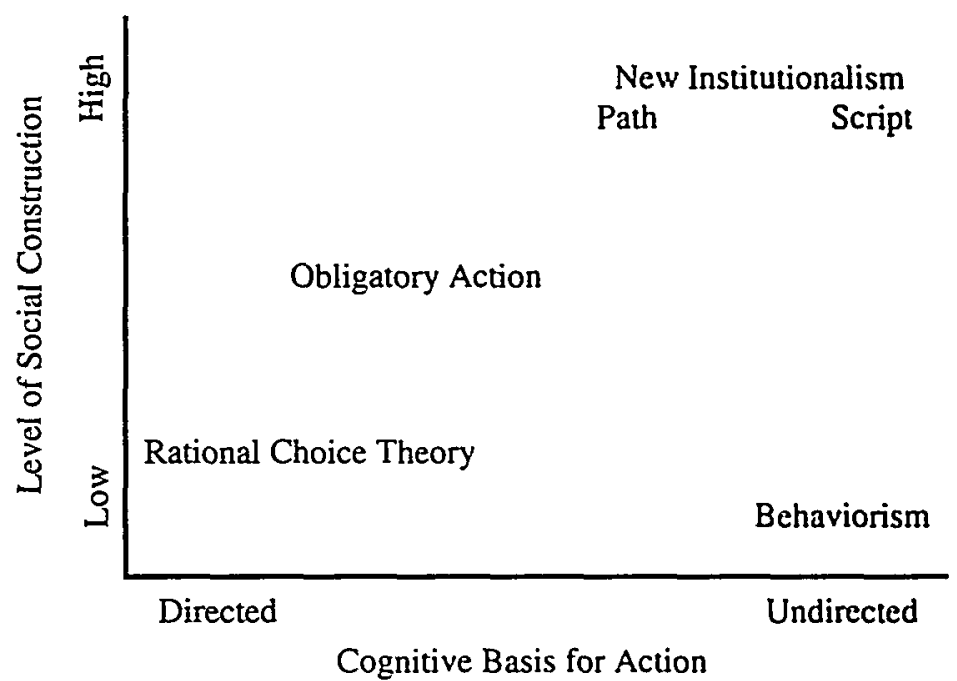

\section{From Low to High Construction}

The vertical axis in the graph above measures a continuum along levels of social construction. Low-construction or realist theories treat actors as presocial entities, the human equivalent of the biologist's fruit flies or the behaviorist's pigeons. Skinnerian behaviorism, which models individuals as "black boxes" responding to external stimuli, most closely approximates this extreme,,$^{238}$ although many rational choice theories also come close. High-construction or phenomenological theories, on the other hand, picture actors as thoroughly social, completely constituted through their relations with others. New Institutionalism pushes in this direction, though perhaps not as far as do many theories of human action associated with postmodernism.

As the graph indicates, different positions along the social construction axis exist; this is so not only with regard to the broad theoretical groupings listed, but also within each of these. Consider in particular rational choice models. Among rational choice theorists, many suppose actors stand wholly outside of social influences. But recently (and not so recently if one includes the work of Robert Ellickson), ${ }^{239}$ legal theorists have developed an

238. See id. at 154-55.

239. A decade ago, Ellickson urged law-and-economics scholars to attend to the lessons developing in psychology and sociology regarding human behavior. See Robert C. Ellickson, Bringing Culture and Human Fraily to Rational Actors: A Critique of Classical Law and Economics, 65 CHI.-KENT L. REV. 23, 25 (1989). He also anticipated the recent tum to norm analysis. See ROBERT C. ELLICKSON, ORDER WITHOUT LAW (1991). 
approach to rational choice theory that incorporates social norms. ${ }^{240}$ Larry Lessig identifies this trend as a principal component of what he terms the "New Chicago School," ${ }^{241}$ which counts among its members both Richard McAdams and Eric Posner. ${ }^{242}$ The increased attention to norms moves from the actor-as-fruit-fly position to a more nuanced conception of actors as at least somewhat responsive to the culture in which they find themselves. ${ }^{243}$

The New Chicago School's increased appreciation for the role of social norms helps to bridge the gap along the constructivist axis between rational choice theory and what is labeled "obligatory action" theory. ${ }^{244}$ Obligatory action theory in many ways constitutes the "old institutionalism," particularly in the field of organizational analysis. ${ }^{245}$ Obligatory action posits a model of human behavior in which actors consciously respond to internalized social norms. ${ }^{246}$ Under this approach, actors are in part constituted by the roles within which they function and the attendant values they internalize. ${ }^{247}$

Despite a move along the social construction axis, both the New Chicago School and obligatory action theory remain at the "directed" pole

240. See, e.g., Robert Cooter, Expressive Law and Economics, 27 J. LEGAL SrUv. 585 (1998); Dan M. Kahan, Between Economics and Sociology: The New Path of Deterrence, 95 MICH. L. REV. 2477 (1997); Dan M. Kahan, Social Influence, Social Meaning, and Diterrence. 83 VA. L. REV. 349 (1997); Dan M. Kahan \& Tracey L. Meares, Foreword: The Coming Crisis of Criminal Procedure, 86 GEO. L.J. 1153 (1998); Lawrence Lessig, The Regulation of Social Meaning, 62 U. CHI. L. REV. 943 (1995) [hereinafter Lessig, Regulation of Social Meaning): Lawrence Lessig, Social Meaning and Social Norms, 144 U. PA. L. REv. 2181 (1996): Cass R. Sunstein, Social Norms and Social Roles, 96 COLUM. L. REV. 903 (1996). Richard McAdams provides an overview of this new approach. See Richard H. McAdams. The Origin. Development. and Regulation of Norms, 96 MICH. L. REV. 338 (1997).

241. Lawrence Lessig, The New Chicago School, 27 J. LEGAL STUD. 661 (1998).

242. See, e.g., McAdams, supra note 240; Eric A. Posner, The Regulation of Groups: The Infiuence of Legal and Nonlegal Sanctions on Collective Action, 63 U. CHI. L. REV. 133 (1996) (examining the role of social norms in promoting collective action).

243. The move toward constructivism within the New Chicago School remains fairly limited. however. Most articles, like those by Posner, see supra note 242, and McAdams, see supra note 240, ignore constructivist arguments altogether. Lessig is something of an exception, though he too retains an exclusive focus on directed action and does not explore in depth the implications of constructed social identities. See Lessig, Regulation of Social Meaning, supra note 240, at 946. 949-50.

244. I adopt this term from Mark Suchman, who in tum attributes it to James March. See Mark C. Suchman. On Beyond Interest: Rational. Normative and Cognitive Perspectives in the Social Scientific Study of Law, 1997 WIS. L. REV. 475, 479 (citing James G. March, Decision Making Perspective: Decisions in Organizations and Theories of Choice, in PERSPLCTIVES ON ORGANIZATION DESIGN AND BEHAVIOR 205, 222 (Andrew H. Van de Ven \& William F. Joyce eds., 1981)).

245. See DiMaggio \& Powell, supra note 12. at 11-15; W. Richard Scott, Institutional Theory and Organizations, in THE INSTITUTIONAL CONSTRUCTION OF ORGANIZATIONS: INTERNATIONAL AND LONGITLdiNal STUdiES at xi, xviii (W. Richard Scott \& Søren Christensen eds., 1995).

246. Some members of the New Chicago School, while retaining a focus on directed action. have turned their attention to the internalization of norms, thus further approximating obligatory action theory. See McAdams, supra note 240, at 376-86; see also Robert Cooter, Law and Unified Social Theory, 22 J.L. \& SOC'Y 50, 60-62 (1995).

247. See Suchman, supra note 244, at 479 (stating that obligatory action theory "emphasizes how people form their identities, how people define and categorize the situations in which they find themselves, and how people learn their parts in the social drama"). 
on the cognitive axis. In both approaches, action remains wholly managed by conscious thought-in the case of rational choice theory, the pursuit of self-interest, and in the case of obligatory action theory, regard for compliance with learned norms. Although New Institutionalism resembles obligatory action theory in positing the socialization of organizational actors, New Institutionalism emphasizes, in contrast, the cognitive rather than affective basis of socialization; it stresses mental routines instead of the self-conscious pursuit of internalized values. ${ }^{2.48}$

Returning to the continuum along constructivist lines among social science theories of behavior, something akin to the following ordering emerges: behaviorism (actor as pigeon); rational choice theory (actor as fruit fly, presocial and autonomous); New Chicago School (actor consciously responsive to social norms); obligatory action theory (actor consciously responsive to internalized social norms); and New Institutionalism (actor constituted through social action).

\section{From Directed to Undirected Behavior}

The horizontal axis measures a continuum between action that is directed by completely conscious processes at one end and undirected action instigated by completely nonconscious mechanisms at the other. The variable here is the relative weight assigned to intentional versus nonintentional spurs to action. The language of directedness highlights the level of self-awareness involved in action, yet seeks to avoid the baggage associated with the language of consciousness and, more particularly, unconsciousness.

Again, placements on the graph indicate the relative position of the various theories along this axis. Behaviorism, which models human action as the automatic response to external stimuli, leaving no room for conscious action, seems to stake out the undirected extreme. ${ }^{2.99}$ At the opposite pole lie the rational choice theories that posit that human action results solely from thoughtfulness. Again, however, distinctions exist among rational choice theories. Within that school. significant advances have been made in the analysis of the constraints that organizations, social structures, and iteration impose on knowledge ("bounded rationality")

248. According to DiMaggio and Powell, "Not norms and values but taken-for-granted scripts, rules, and classifications are the stuff of which institutions are made. Rather than concrete organizations eliciting affective commitment, institutions are macrolevel abstractions, 'rationalized and impersonal prescriptions,' shared 'typifications,' independent of any paricular entity to which moral allegiance might be owed." DiMaggio \& Powell. supra note 12, at 15 (citation omitted). But see Suchman \& Edelman, supra note 23, at $911-12$ (noting that some New Institutionalists are "agnostic" regarding the mechanisms-cognitive. rational, nomative, or otherwise- by which organizational life influences behavior).

249. See Jepperson, supra note 16 , at 154.

250. Theories of bounded rationality emphasize the inability of human arrangements to deliver complete and accurate information to decision makers. Such theories lie at the hear of transaction-cost economics. See generally HERBERT A. SIMON, ADMINISTRATIVE BEHAVIOR (3d 
political theory"). ${ }^{251}$ To a large extent, both bounded rationality and positive political theory emphasize purposefully directed action. Yet they also mark something of a departure along the directed/undirected axis from traditional rational choice theories, insofar as the new approaches replace the assumption of full awareness of interests and consequences with more limited claims of partial awareness, especially as to the connection between means and ends. Moreover, positive theory in particular argues that the dictates of the situation, rather than exclusively strategic calculations, sometimes guide human behavior. ${ }^{252}$ In these ways, such theories move away from a position that stresses the fully directed nature of human behavior. Consider in addition the approach taken recently under the title $A$ Behavioral Approach to Law and Economics. ${ }^{253}$ The authors suggest that actors occasionally respond rationally to recognized limits on knowledge, self-discipline, and self-interest. ${ }^{254}$ While the theoretical emphasis remains on directed action-namely, on appropriate responses to recognized constraints on rationality-the authors correctly emphasize that undirected spurs to human action pose a distinct challenge to rational choice theory. ${ }^{255}$

In terms of a continuum, social science theories of behavior fall along the cognitive axis as follows: rational choice theory (action solely the result of intent); bounded rationality (action the result of intent limited by informational constraints); positive political theory (action dictated by intent as well as by situational constraints); behavioral economics (action dictated by intent, often informed by anticipated cognitive distortions); New

ed. 1976); OLIVER E. WILLIAMSON, THE ECONOMIC INSTITUTIONS OF CAPITALISM (1985); R.H. Coase, The Problem of Social Cost, 3 J.L. \& ECON. 1 (1960).

251. Positive theory applies game theory to politics, stressing iteration within structured environments. Common in political science, positive theory has also found expression in legal scholarship. See, e.g., Daniel B. Rodriguez, The Positive Political Dimensions of Regulatory Reform, 72 WASH. U. L.Q. 1, 43 (1994) ("Positive political theory describes regulatory policymaking as a part of a world in which political actors function within institutions rationally and strategically in order to accomplish certain goals."). Among political scientists, such theorizing sometimes goes by the name of "new institutionalism." For a critique, see Howard Gillman, The New Institutionalism: More and Less than Strategy: Some Advantages to Interpretive Institutionalism in the Analysis of Judicial Politics (pt. 1), LAW \& CTS. (American Political Science Ass'n, St. Louis, Mo.), Winter 1996-1997, at 6. For a comparison of this approach with the one generally described here, see Michael McCann, How the Supreme Court Matters in American Politics: New Institutionalist Perspectives, in THE SUPREME COURT AND AMERICAN POLITICS: NEW INSTITUTIONALIST INTERPRETATIONS (Howard Gillman \& Cornell Clayton eds., 1999).

252. For this reason Karen Orren and Stephen Skowronek argue that the "positive theory of institutions" "is not only a new institutionalism that formalizes the strategic behavior of individuals, it is also a 'new behavioralism' in which self-interested individuals are led by institutional arrangements toward 'structure-induced equilibria."' Karen Orren \& Stephen Skowronek, Beyond the Iconography of Order: Notes for a "New Institutionalism." in THE DYNAMICS OF AMERICAN POLITICS: APPROACHES AND INTERPRETATIONS 311, 315-16 (Lawrence C. Dodd \& Calvin Jillson eds., 1994).

253. See Christine Jolls et al., A Behavioral Approach to Law and Economics, 50 STAN. L. REV. 1471 (1998).

254. See id. at 1477-79.

255. See id. at 1473, 1476; see also Christine Jolls et al., Theories and Tropes: A Reply to Posner and Kelman, 50 STAN. L. REV. 1593 (1998). 
Institutionalism; and behaviorism (spontaneous responses directly triggered by external stimuli).

\section{Script and Path Institutionalism}

On the cognitive axis, New Institutionalism lies close to the undirected end. Yet, on the question of cognition, an important division exists in New Institutionalist theories. Reflecting this, I differentiate New Institutionalism in the graph by the terms "script" and "path." Although New Institutionalist literature does not use these terms, they help distinguish two different claims regarding the operation of institutions in everyday and organizational life..$^{256}$

"Script institutionalism" refers to institutional models of human behavior that emphasize stock prescriptions of conventional action, in which action stems from ingrained habits and responses with virtually no conscious thought. I use this term because such theories seem to picture actors following scripts, in the sense that they engage in prescribed routines appropriate to the situation with no consideration given to the actions in which they engage. To be sure, such accounts leave room for thoughtfulness, particularly where it is required to categorize the situation-though categorization may well be achieved with no conscious thought at all. Moreover, script institutionalism specifically contemplates the occasional failure or interruption of routines, positing that when background practices are drawn into question, thoughtfulness occurs. ${ }^{237}$ Once actors identify a situation, however, and in the absence of a failure or interruption of routines, script institutionalism posits that unconsidered, established practices dictate most behavior. ${ }^{258}$

256. Mark Suchman and Lauren Edelman distinguish divergent orientations toward cognition in New Institutionalism with the labels "cognitive" and "behavioral" institutionalism. See Suchman \& Edelman, supra note 23, at 910-13. According to them. "cognitive institutionalists emphasize schemata, expectations, and accounts," id. at 910, while "work in [the behavioral institutionalism] mold is less committed to a purely cognitive model of human action and is more willing to incorporate rational, normative, and structural factors, as well," id. at 912. This division is not sharp, as few cognitive institutionalists ane so wedded to a deterministic approach as to be unwilling to concede important behavioral roles to rational and normative forces as well. while behavioral institutionalists concede the significance of cognitive influences. Script and path institutionalisms advance complementary but distinct models regarding how the cognitive influences of institutions manifest themselves; thus, they constitute models most salient to those whom Suchman and Edelman term cognitive institutionalists.

257. Berger and Luckmann emphasize the durability of institutions up to the point that they fail to meet particular challenges:

The validity of my knowledge of everyday life is taken for granted by myself and by others until further notice, that is, until a problem arises that cannot be solved in terms of it.... Only when my maxims fail "to deliver the goods" in the world to which they are intended to apply are they likely to become problematic to me "in eamest." BERGER \& LUCKMANN, supra note 14 , at 44 .

258. Script institutionalism resembles Alfred Schutz's "cook-book knowledge":

The cook-book has recipes, lists of ingredients, formulac for mixing them, and directions for finishing off. This is all we need to make an apple pie, and also all we need to deal with the routine matters of daily life. ... Most of our daily activities from 
In contrast, another variant of institutionalism stresses the manner in which taken-for-granted knowledge prescribes not the specifics of action but its boundaries, channeling actors along certain courses within which some significant latitude in decision making is exercised. ${ }^{259}$ I characterize this approach as path institutionalism. Path institutionalism emphasizes background understandings and grammars that constrain but do not completely dictate action. ${ }^{260}$ The path argument focuses on taken-forgranted knowledge, the nine-tenths of the iceberg beneath the surface, picturing such knowledge as the nearly indispensable and largely unconsidered basis on which purposeful decisions are made. Among New Institutionalists, path institutional explanations seem more common than script versions. ${ }^{261}$ Further from the undirected end of the continuum, path institutionalism posits a weaker claim regarding the role of background understandings and rules, leaving more room for directed action. ${ }^{262}$

Notice that script and path institutionalism do not operate as independent cognitive mechanisms, but instead complement each other. While script institutionalism describes a first-order phenomenon in the sense that scripts are spontaneously triggered and involve little or no conscious thought, path institutionalism implicates a second-order phenomenon wherein thoughtfulness occurs but nevertheless remains institutionally channeled. In this way, path institutionalism explains how institutions continue to wield a cognitive influence even when actors selfconsciously reject the scripts set out for them. Nevertheless, because different levels of consciousness operate in all decisions, no action is purely script- or purely path-dependent; actions drawing on institutions always combine the two. Together, script and path institutionalism suggest an image of day-to-day activity that is largely unreflective, yet also

rising to going to bed are of this kind. They are performed by following recipes reduced to automatic habits or unquestioned platitudes.

2 SCHUTZ, supra note 212 , at 73-74.

259. See, e.g., Suchman, supra note 244 , at $482-84$.

260. Jack Balkin offers a theory similar to path institutionalism, though he does so in the language of memes and cultural software. See J.M. BALKIN. CULTURAL SOFTWARE: A THEORY OF IDEOLOGY (1998).

261. In general, theories of path institutionalism seem more akin to the social constructivism of Berger and Luckmann than do script theories, which seem more indebted to Garfinkel's ethnomethodology.

262. Indeed, as the constraining influence of background institutions is relaxed. path institutionalism loses explanatory power. At a certain point, theoretical parsimony may suggest proceeding in terms of rational choice or other models while acknowledging institutional constraints on cognition as well as institutional influence on identity. See Peter Abell. The New' Institutionalism and Rational Choice Theory, in THE INSTITUTIONAL CONSTRUCTION OF ORGANIZATIONS, supra note 245, at 11 [hereinafter Abell, New Institutionalism and Rational Choice]. This is not to suggest that rational choice theory therefore should be given "paradigmatic privilege," as Abell elsewhere suggests. See Peter Abell, Is Rational Choice Theory a Rational Choice of Theory?, in RATIONAL CHOICE THEORY: ADVOCACY AND CRITIQUE 183, supra note 199 , at 203. But neither is it to argue that institutional explanations deserve preeminence. Model preference should follow from matching the behavior one seeks to explain against the relative strengths of the different models. 
commonly interrupted, prompting varying ratios of thoughtlessness and thoughtfulness. ${ }^{263}$ One should not model human action as directed or undirected, but rather as shifting combinations of the two. ${ }^{204}$

Notice as well that both scripts and paths not only constrain but also enable social interaction. In sociology, it has long been common to regard the individual as "shackled by institutions, even threatened by them."265 Yet institutional analysis emphasizes that institutions are necessary to social interaction. One should not picture institutions as constraints, from which once released individuals would be free to engage with each other as they saw fit. Rather, institutions limit but also facilitate what actors can do and who they can be. ${ }^{266}$ Neither necessarily good nor bad, scripts and paths are indispensable to social life.

\section{New Institutionalism and Rational Choice Theory}

The preceding discussion blurs the central distinctions between rational choice theory and institutionalism. Restoring clarity, even if through simplification, helps to relocate these schools in opposite quadrants in the constructivist/cognitive matrix used above. On the question of social construction, rational choice theory in effect treats social actors as autochthonous-primordial and presocial beings. ${ }^{207}$ Social actors possessing stable interests function as independent units capable of full rationality and impervious to changes induced through social interactions: They act, but are not acted upon. ${ }^{268}$ With respect to the cognitive basis of action, rational choice theory pictures actors as directing their actions

263. Cf. Ellen Langer et al., The Mindlessness of Ostensibly Thoughtul Action: The Role of "Placebic" Information in Interpersonal Interaction, 36 J. PERSONALITY \& SOC. PSYCHOL. 635 (1978).

264. Cf. Abell, New Institutionalism and Rational Choice, supra note 262. at 12 ("Should we model everyday human actions.... as characteristically calculative or as unreflectively institutionalized? I am sure the empirical answer is both. and it may be useful to take the degree of calculation (optimal search) as a fundamental variable.").

265. Mary douglas \& Steven NeY, Missing Persons: a Crmtique of the Soclal SCIENCES 154 (1998).

266. See Jepperson, supra note 16, at $1+6$ ("Institutions are not just constraint structures; all institutions simultaneously empower and control."). Jack Balkin extends this point by noting that. because background understandings not only limit but also empower, such understandings should not be assigned an a priori normative valence. "Each ability created carries with it a necessary disability, each perspective opened up carries with it a necessary blindness. In our cultural software benefit and [disadvantage] are yoked together, and so our altitude toward our cultural software can be neither positive nor neutral nor pejorative. It must be ambivalent." BALKIN, supra note 260 , at 286 .

267. See Jepperson, supra note 16 , at 153.

268. Because rational choice theory understands actors as presocial and impervious to change, actors qua actors receive little theoretical attention. Compare the New Institutionalist position: "Actors enact as much as they act: What they do is inherent in the social definition of the actor itself.... Hence the common notion that the actor performs the action is only a halftruth-at the institutional level, action also creates the actor." Meyer et al., supra note 236, at 22. 23. 
exclusively through conscious processes. Rationality emerges as a universal, constant cognitive facility. ${ }^{269}$

In contrast, on the constructivist question institutional analysis argues that identity results from social interaction. ${ }^{270}$ With this approach, neither the social actors who engage one another nor the terms of their engagement can be understood except in cultural context. Social interaction constitutes actors: their identities, access to resources, relative social positions-even the "interests" they pursue and the relationship between means and ends they perceive-arise out of social exchange. ${ }^{271}$ Simultaneously, on the cognitive side, the "rationalities" that social actors employ, their strategies, the repertoires of action to which they have recourse-all of these operate against a collection of received understandings and rules of knowledge regulation. Rationalities emerge as but one component among a set of cognitive spurs to action. Institutionalism, path or script, focuses theoretical attention not on actions in isolation, but on the organizational contexts in which interaction occurs, and on the received grammars dictating individual behavior.

To conclude with an example that sharpens the contrast between the social science theories of human action considered here, consider the hackneyed story of a traveler finishing a meal at a roadside café to which she believes she will never return. ${ }^{272}$ Does she leave a tip? Rational choice theory suggests she calculates the expected utility to herself of doing so and behaves accordingly, probably leaving nothing. The obligatory action model posits that the traveler instead evaluates the situation against her internalized norms, and in abiding by those norms probably tips. Script institutionalism, on the other hand, suggests that our traveler leaves a tip without giving it much thought. If asked directly why she acted as she did, the rational choice and obligatory action models predict the traveler is able to explain her action easily, as she has consciously considered it. For the same reason, if given a chance to reconsider, those schools anticipate she would not alter her behavior. Script institutionalism predicts, however, that the traveler would be challenged by a question as to her reason for tipping, because she had given the matter no thought. Moreover, institutional analysis suggests that once having thought about it, she might react in various ways. In any event, path institutionalism suggests that her decision will depend on her subscription to rules of appropriate behavior that remain shrouded and beyond her awareness.

Script and path institutionalisms model types of activity-action taken in an undirected manner, or if directed, dependent on background

269. Again, as with the nature of social actors, where there is no change, there is nothing to theorize-rationality is postulated rather than studied. But see supra notes 168-179 and accompanying text (discussing recent trends).

270. See Meyer et al., supra note 236, at 12; see also Scott, supra note 245, at xi, xviii.

271. See Friedland \& Alford, supra note 13, at 238-39; Wildavsky, supra note 235, at 5.

272. The following is adapted from DiMaggio \& Powell, supra note 12 , at 37 n. 24 . 
knowledge and rules-not otherwise adequately explained by rational choice or obligatory action theories that stress constant thoughtfulness. In the next Part, I argue that script and path institutionalisms compellingly explain both the judges' actions in nominating grand jurors and their testimony on the stand in East LA 13.

\section{INSTITUTIONAL ANALYSIS AND THE LOS ANGELES SUPERIOR COURT}

The judges on the Los Angeles superior court discriminated against Mexican Americans in nominating grand jurors. Institutional analysis suggests why: The judges uncritically followed a script requiring the nomination of personal and professional acquaintances. In this Part, I argue that a nomination script was followed by the Los Angeles superior court judges. I also argue that an institutional path channeled the judges' efforts to justify their selection practices once called to the stand in East LA 13. In effect, Acosta was correct: The judges did not have to arrive at work in the morning with the intent to discriminate against Mexican Americans for discrimination to occur. Instead, they had only to show up.

\section{A. Discrimination by Script}

\section{Believing the Judges}

The nominating practices of the Los Angeles superior court judges excluded most Mexican Americans. Yet virtually every judge testified that he had "absolutely" no intention to discriminate. ${ }^{273}$ To square the judges' actions with their testimony, one might postulate that they intended the results of their actions and testified falsely about their intentions. Is it plausible that thirty-three judges took the witness stand in East $L A 13$ and lied? To answer this, one must evaluate the character of the judges, as well as the likelihood that they had something to lie about. One need not and probably should not understand the judges as paragons of rectitude. ${ }^{274}$ Nevertheless, it seems reasonable to assume that they were no more venal, and perhaps, because of their office, a little less so, than the rest of us. With regard to whether they had something to lie about, in the context of the East Los Angeles cases, conceivably some judges harbored conscious animus toward Mexican Americans. Little evidence of consciously held racial animus has surfaced, however. ${ }^{275}$ Given the relative recency of the cases and the diversity of backgrounds among the judges, it seems unlikely that a

273. See Transcript, supra note 8, at 399-400; supra notes 152-153 and accompanying text.

274. See supra notes 139-144 and accompanying text (discussing the testimony of Alameda County superior court judges).

275. But see infra notes 321-322 and accompanying text (discussing the comments of San Jose superior court judge Gerald Chargin). 
majority of them intentionally embraced and acted on racial hatred. There may well have been some element, even some significant element, of a willingness to dissemble or of racial hostility. But an account that centers on intentional discrimination and outright lying is simply implausible.

Institutional analysis does not need to postulate that the judges lied in order to reconcile their testimony and actions. Instead, script institutionalism stresses the automatic quality of their actions in nominating their acquaintances, and largely accepts their emphatic denials of discriminatory intent. Institutional analysis easily accounts for the judges' testimony, so difficult to square under theories stressing purposefulness, because it suggests that they operated not mindfully but relatively automatically in adopting the nomination strategy of picking from among acquaintances. Thus, most judges were not duplicitous about, but rather honestly insisted on, a lack of intent to discriminate. They formed no such intent, script institutionalism contends, because with respect to their nomination practices they formed little intent at all. This is not to depict the judges as somnambulists-far from it. They no doubt engaged consciously in making specific nominations-calling on friends, weighing the qualities of various acquaintances, perhaps fretting about finding anyone, maybe soliciting recommendations from fellow judges. But all of this action occurred within the context of a script that delineated the accepted, expected manner of grand juror selection. However directed their actions were within the script's terms, the judges acted with little conscious thought in conforming to the "pick your friend" script.

\section{Scripts in Organized, Office-Holding Environments}

Harold Garfinkel recognized that for routine functions in organized settings, widely accepted, standardized responses develop that are consistently but mindlessly deployed. ${ }^{276}$ New Institutionalists such as Lynne Zucker have carried this argument further, employing an ethnomethodological approach to demonstrate that knowledge is more highly institutionalized-that is, more taken-for-granted-in organizational contexts, and still more so in organized settings involving office-holding. ${ }^{277}$ An extended experiment by Zucker renders more plausible the claim that the judges of the Los Angeles superior court followed a script in selecting grand jury nominees from among their friends and friends of friends.

To demonstrate the effects of organizational structure and officeholding on knowledge, Zucker designed an experiment based on the autokinetic illusion, asking subjects to estimate the distance traveled by a

276. As Garfinkel writes, "In exactly the ways in which a setting is organized, it consists of methods whereby its members are provided with accounts of the setting as countable, storyable, proverbial, comparable, picturable, representable-i.e., accountable events." GARFINKiL. supra note 15 , at 34.

277. See Zucker, supra note 21 , at 85-86. 
stationary point of light in a dark room. ${ }^{278}$ Zucker placed subjects in teams of two-one subject who had judged a previous set of light exposures and one who was new to the situation. ${ }^{279}$ She asked subjects who had already judged a set of exposures to estimate the distance traveled first, followed by the new person. In the first set of light exposures, a confederate played the role of the experienced subject. After a number of exposures, the confederate left the room, the first subject assumed the role of the experienced team member, and a new subject came in, and so on through succeeding "generations." ${ }^{280}$ In each instance, the confederate "judged" the light to have moved a mean of twelve inches. considerably further than the average judgment of light movement reached by subjects in a control situation, just over four inches. ${ }^{281}$ Zucker sought to measure first the impact of the confederates' exaggerated estimates on the estimates made by initial subjects, and second, the degree to which subjects transmitted high estimates to successive generations.

The only variation in the structure of the tests came in the instructions given. Zucker crafted three separate sets of instructions to capture the effect of differentially organized settings. The first set of instructions measured "personal influence" - that is, influence in an unorganized context. ${ }^{282}$ The second set sought to capture the influence of moderately structured settings, what Zucker termed "organizational" context. ${ }^{283}$ Finally, the last set of instructions focused on highly organized settings, involving what Zucker called "office-holding." ${ }^{284}$ Other than the instructions given, little varied

278. See id. at 88.

279. See id. at 89.

280. See id.

281. See id. at $92-93$.

282. The "personal influence" instructions provided in perinent part: "This study involves problem solving in groups. You will be participating with another person." Id. at 91 .

283. The "organizational" instructions provided as follows:

This study involves problem solving in model organizations. You will be participating with another organizational member. Your two-member organizauon is meant to be a small-scale model of much larger organizations. and it has many of the same characteristics they do.

Most large organizations continue even though individual members. or even whole divisions, may be replaced, due to changing jobs, retirement. reorganization, etc. The model organization in which you will participate also will have this feature: members who have been in it for a while will drop out, and new members will join. but the job will go on. Thus, performance of any single member may not be important to Id. the organization as long as the job continues to be done.

284. These "office-holding" instructions incorporated the following directions into those given to establish "organizational" context:

Large organizations also place members in different positions, often according to the amount of time spent in the organization. The model organization in which you will participate also has this feature- the member who has spent the most time in the organization will be the Light Operator. When she leaves, you will become the Light Operator.... 
between the tests. ${ }^{285}$

Unsurprisingly, initial subjects' estimates increased when made after exposure to the exaggerated numbers given by the confederates, irrespective of the form of the instructions given. This result is unsurprising because the availability heuristic-the tendency of recently received information to skew judgments in predictable directions-suggests such an effect. ${ }^{286}$

Zucker's experiment, however, produced two results not explained by the availability heuristic, results important to the claim that organizational structure increases the institutionalization of knowledge. First, she found that the initial subjects' mean estimates varied according to the instructions given them: While the confederates' estimates consistently averaged twelve inches, the initial subjects' estimates rose respectively in the personal influence, organizational context, and office-holding settings, from 6.53 to 9.44, and finally, to 10.51 inches. ${ }^{287}$ Higher estimates of light movement correlated positively to more organized settings. Second, the rate of generational transmission also varied according to the instructions given: Zucker calculated that subjects' distance estimates would return to the baseline mean of just over four inches after seven generations in the personal influence condition, but not until the twenty-ninth generation in the organizational setting, and not even by the thirty-eighth generation in the office context. ${ }^{288}$ As with mean estimates, higher rates of transmission positively correlated to more organized settings.

Consider, in addition, information gleaned from a postexperimental questionnaire. The questionnaire asked subjects first to evaluate the "certainty" they felt in their estimates of light movement, and second to assess the "difficulty" they experienced in making such estimates. Zucker found that "[s]ubjects were much less certain of their accuracy in the personal-influence condition than in either of the more institutionalized conditions." 289 She also noted that "fewer subjects in the office condition reported difficulty" compared with those in the organizational condition, while "[n]early all subjects in the personal influence condition reported

... The Light Operator in each case must depress a button to activate the light.

From then on, the timing and motion of the light is controlled automatically until the Id. next trial.

285. There was slight variation insofar as subjects in the "office-holding" set were given a switch to turn on the light. See id. at 92. In addition, while subjects in the "personal influence" and "organizational influence" tests were addressed by name, subjects in the "office-holding" tests were referred to as "Member 1" and "Member 2." See id.

286. See Amos Tversky \& Daniel Kahneman, Availability: A Heuristic for Judging Frequency and Probability, 5 COGNITIVE PSYCHOL. 207 (1973).

287. See Zucker, supra note 21 , at 95.

288. See id. at 94.

289. Id. at 97 . 
difficulty." ${ }^{290}$ Certainty among subjects increased positively with higher levels of organization, as did the apparent ease of rendering judgments.

The results of Zucker's experiment cannot be explained in terms of motivational effects alone. Accounts stressing the pursuit of self-interest seem unable to explain the positive correlation between mean estimates, transmission rates, and the instructions provided. For instance, no reward system-material or symbolic-encouraged or penalized particular answers in one setting more than another. Persons in the personal-influence setting had neither more nor less incentive to alter their estimates than persons in the office-holding context. Alternatively, accounts emphasizing conscious allegiance to role requirements might explain the positive correlation between instructions and mean estimates, but cannot explain the corresponding increase in the reported ease of judgment. The questionnaire demonstrated that subjects felt more certain, not less, the more their evaluations deviated from the mean estimates reached by members of the control group. Thus, subjects did not seem to experience a conscious conflict between the estimates "required" by role demands and their actual perceptions of light movement. It seems likely that the consistent differences in estimates demonstrated in Zucker's experiment reflect not subjects' conscious decisions to alter their judgments, but rather cognitive distortions differentially induced by different "organizational" settings.

Zucker's experiment shows, importantly, that contextual conditions produce varying degrees of cognitive distortion that correspond to shifting levels of apparent organization. She found that actors viewed knowledge in seemingly organized settings as "more definitely patterned" and "more formal and less personal." ${ }^{291}$ She noted an even more dramatic effect when actors perceived knowledge to be linked to an office, concluding that subjects treat such knowledge as "nonpersonal and continuing over time," "part of the external world," and "objective." ${ }^{292}$ Zucker concluded that "social knowledge once institutionalized exists as a fact, as part of objective reality, and can be transmitted directly on that basis. For highly institutionalized acts, it is sufficient for one person simply to tell another that this is how things are done." ${ }^{293}$ Zucker's experiment powerfully

290. Id.

291. Id. at 86 .

292. Id. at 85-86.

293. Id. at 83. Notice that the "cognitive" claim made here, when compared to a claim rooted in the availability heuristic, offers more detail in specifying sources and magnitudes of influence. While the availability heuristic suggests that recent exposure to information may "prime" an actor in a manner that skews her judgment. Zucker predicts differing degrees of cognitive effect given such factors as context and role. More concretely, while the availability heuristic predicts that the confederates' inflated claims would lead to an upward distortion in subjects' estimates, Zucker's experiment suggests that the description of the confederate plays a significant role in determining the degree of cognitive influence. Whether the confederate is presented as a "person," an "organizational co-member," or an "officeholder" influences whether subjects perceive the source of information as more or less formal and objective, and so influences the magnitude of the cognitive distortion generated. 
suggests that some settings more than others-those that are more highly organized, and more defined by office-holding-more readily produce taken-for-granted knowledge. ${ }^{294}$

What, then, of the Los Angeles superior court judges? Obviously, they operated within a highly organized framework. The superior court constituted a formalized, regularized bureaucracy, with clearly delineated roles and strongly routinized conduct. In addition, the judges held important offices within that organization. Indeed, the office of "superior court judge" occupied a central, if not the defining, position within the organization in which it was embedded. Zucker's experiment, and New Institutionalism generally, suggest that scripts operated at an unconsidered level among the Los Angeles superior court judges. ${ }^{295}$ The judges' practice of nominating their friends and acquaintances to serve as grand jurors seems to constitute one such script.

\section{Uniformity of Selection Practices}

Perhaps the best evidence that the judges followed a script is the remarkable uniformity in their selection practices. It was not the case that some judges relied on their clerks, others on the jury commissioner, some on advertisements put in the paper to solicit applications, some on random selection from voter or taxpayer lists, a few on names submitted by elected officials, and still others on names generated by respected civic organizations. ${ }^{296}$ If conscious decision making and personal motives drove the judges, one would expect to find such a wide range of practices. However, judge after judge in East LA 13 told nearly the same story in explaining his selection process: He casually nominated his friends and acquaintances. Recall that nine out of ten nominees came from within the judges' circles. ${ }^{297}$ Remember that among the judges who testified in East $L A 13$, only one described a single instance of pursuing a method other than nominating an acquaintance or someone recommended by an acquaintance

294. See id. at 86 . Keep in mind that it was only superficial descriptions of an otherwise constant set of interactions that generated the dramatic differences in distance estimates and transmission rates Zucker recorded. The test setting constituted an "organization" only because subjects were told that it did; office holders held an "office" only to the extent that it involved turning on a light otherwise connected to a timer. Zucker's experiment reveals that changes in setting can produce remarkable changes in actors' relationships to knowledge. It also demonstrates that for such changes to produce cognitive effects, the changes in context themselves need not be dramatic. Even redescriptions of an otherwise constant setting may substantially alter the extent to which actors take knowledge for granted.

295. Although I do not engage in a comparative institutional analysis-for example, one that attempts to measure the institutional dynamics of courts versus legislatures-Ed Rubin conjectures that courts, more than other forms of government, rely on "practical reason and consensual judgment." Rubin, supra note 24, at 279.

296. All of these methods, it should be noted, found use as the scandal over grand jury nomination practices reached critical proportions in the years following East $L A / 3$ and Biltmore 6. See supra notes 133-138, 145-148 and accompanying text.

297. See supra note 62 and accompanying text. 
or fellow judge. ${ }^{298}$ Script institutionalism predicts exactly this uniformity. Scripts are not idiosyncratic habits rendered routine through long repetition. Instead, group interaction produces scripts, all the more so within organized settings and among office holders.

Superior court judge William Levit insisted on the witness stand that the judges made their nominations individually, without consulting one another:

Now, our Court Rule says that each Judge will nominate two people. We don't do it as a group, we do it individually.... We don't do this as a group. I have never discussed my nominations with any other Judge, and I don't know of any who have discussed it with me. ${ }^{299}$

Perhaps, regarding individual nominees, Judge Levit was correct. But with respect to the process, he surely erred. Contrary to his sense, the judges subscribed to a nominating system dictated by group dynamics. Judges learned from one another, sometimes directly, but also at a nonconscious level. They learned that the appropriate manner of selecting nominees involved selecting from among their friends. They learned that those they personally knew described the world of potential nominees. Script institutionalism explains why almost every judge picked grand jury nominees from a narrow circle of friends and neighbors: It was simply "the way it was done," a taken-for-granted solution to a routine problem. To this extent, the selection of nominees from among a narrow class and professional range-and the resultant exclusion of Mexican Americansreflected not conscious design but unreflective activity. Judges nominated acquaintances in a manner unremarkable and unconsidered, easy and sure, common and legitimate - that is, according to a script.

\section{Criteria, Routine, and Legitimacy in Grand Juror Selection}

There is a striking facet of the judges' selection practices that merits introduction here: the judges' almost total disregard of the criteria and instructions provided them for selecting grand jurors. To be credible, any account of the judges' behavior must grapple with this fact. Institutional analysis posits that the routine nature of the grand juror selection system explains this disregard.

298. See supra note 61 and accompanying text.

299. Transcript, supra note 8, at 594 . 


\section{a. Criteria and Instructions}

Three sources of guidance existed regarding grand juror selection in Los Angeles County: state statute, federal constitutional law, and superior court directive. State statute specified minimum grand juror qualifications. In 1968, the California Code of Civil Procedure listed five prerequisites, only two of which addressed the personal capacity of the prospective juror: Jurors were to possess "sufficient knowledge of the English language" and were required to be "of ordinary intelligence and not decrepit." 300

Several Supreme Court decisions also offered direction regarding nomination practices. The Court on several occasions had held that selectors must not draw only from their acquaintances if among them no minorities were to be found, a result that strongly imputed some responsibility to the grand jury selectors to search beyond their friends and neighbors. ${ }^{301}$ Indeed, a plurality of the Court had stated clearly that jury selectors had the "duty to familiarize themselves fairly with the qualifications of the eligible jurors of the county without regard to race and color." 302

Finally, the superior court judges also received an administrative directive from the presiding judge. Beginning in 1962, the presiding judge on several occasions sent to each sitting judge a letter on selecting grand jurors that included the following instructions: "The Grand Jury should be representative of a cross section of the community. Each Judge must therefore be mindful of the need for making nominations from the various

300. CAL. CIV. PROC. CODE $\S 198$ (West 1968). The other three qualifications were that a grand juror be a U.S. citizen, above the age of 21 , and a resident of California and of the pertinent county for at least one year. See id. In 1971, the following language was added: "A person is competent to act as a grand juror only if he ... is in possession of his natural faculties, of ordinary intelligence, of sound judgment, and of fair character." CAL. PENAL CODE $\$ 893$ (a)(2) (West 1972). Note that in 1966 the Fifth Circuit, sitting en banc, held that it is impermissible racial discrimination for jury selectors to impose subjective requirements beyond the minimum provided by statute, specifically warning that "the desire for competency must not be pursued to the extent that a fair cross-section is prevented." Rabinowitz v. United States, 366 F.2d 34, 55 (5th Cir. 1966) (en banc).

301. See supra note 156.

302. Cassell v. Texas, 339 U.S. 282, 289 (1950) (plurality opinion) (emphasis added). The Cassell plurality wrote as follows:

In explaining the fact that no Negroes appeared on this grand-jury list, the commissioners said that they knew none available who qualified; at the same time they said they chose jurymen only from those people with whom they were personally acquainted. It may be assumed that in ordinary activities in Dallas County. acquaintanceship between the races is not on a sufficiently familiar basis to give ... jury commissioners an opportunity to know the qualifications for grand-jury service of many members of another race. ... When the commissioners were appointed as judicial administrative officials, it was their duty to familiarize themselves fairly with the qualifications of the eligible jurors of the county without regard to race and color. They did not do so here, and the result has been racial discrimination.

Id. at 287-89 (footnotes omitted). The Court reached this result despite the fact that Blacks were represented on the grand jury panel in question in rough proportion to their population in the county. See id. at 285-86. 
geographical locations within the County, and different racial groups, and all economic levels ...." ${ }^{303}$

The criteria and instructions for selecting grand jurors strongly suggested that the judges had an obligation to cast a wide net in making nominations. To be sure, both the statutory requirements and the Supreme Court's holdings may have been somewhat remote sources of guidance, perhaps falling outside of the judges' usual awareness. Nevertheless, the letter from the presiding judge addressed the judges directly. Statutory law, constitutional cases, and court directive told the judges, implicitly and explicitly, to consider geographic, economic, and, most importantly, racial diversity in making their nominations.

How can the judges' actions in consistently nominating their acquaintances be squared with the instructions given them? These instructions admonished the judges, though in different forms and with varying levels of immediacy, of their obligation to select grand jurors from a cross section of the community, including racial minorities. Yet instead they engaged in a practice that systematically excluded minorities. Institutional analysis focuses on the cognitive dynamics of routine actions to explain the judges' disregard of clear instructions.

\section{b. Routine Discrimination}

Consider an experiment by Ellen Langer establishing what she termed "the mindlessness of ostensibly thoughtful action." ${ }^{304}$ Langer asked experimenters to approach persons about to use a photocopying machine in a university library with one of three requests: (1) "May I use the Xerox machine?"; (2) "May I use the Xerox machine, because I have to make copies?"; and, (3) "May I use the Xerox machine, because I' $m$ in a rush?" Note that requests one and two are substantively similar, because the "explanation" that the experimenter seeks to use the Xerox machine "to make copies" adds no new information. On the other hand, requests two and three take the same form: "request" plus "reason." If people respond thoughtfully - that is, to the substance of what is being asked of them-one would expect a similar compliance rate between requests one and two; if people respond to form, on the other hand, one would expect a similar compliance rate for requests two and three.

Langer found that, at least where the interruption was perceived as relatively minor (five pages of copying), sixty percent of the people

303. Letter from Presiding Judge Lloyd S. Nix (July 26, 1967), quored in Transcript, supra note 8, at 289, 299; see also Villalobos, supra note 80, at 108.

304. Langer et al., supra note 263. at 636 . Note that Langer writes as a social psychologist. Her relevance here stems from New Institutionalism's emphasis on scripts. To the extent that organizational actors are posited to follow established routines. Langer's observations regarding behavioral responses to the "form" rather than the "substance" of activity fit neatly within institutional theory. 
complied with request one, while ninety-three percent and ninety-four percent respectively complied with requests two and three. ${ }^{305}$ People responded not to the substance of the request but to its form. Generalizing, Langer suggests the following:

[W] hen the structure of a communication, be it oral or written, semantically sound or senseless, is congruent with one's past experience, it may occasion behavior mindless of relevant details. Clearly, some information from the situation must be processed in order for a script to be cued. However, what is being suggested here is that only a minimal amount of structural information may be attended to .... ${ }^{306}$

Institutionalization involves the development of scripted responses, including sets of cues used to identify types of situations readily. When events trigger such cues, scripted responses follow, sometimes in derogation of relevant, readily available information. Applied to the grand juror selection process, it may well be that, accustomed to letters taking the form of instructions regarding administrative duties, the judges gave the substance of such letters no attention, albeit without forming an intent to ignore them.

The judges' testimony supports this hypothesis. Among the various questions Acosta posed to virtually every judge, one concerned whether they recalled the cross-section letter. The judges' responses are tabulated in Appendix C. Consider Judge Call's response: “Well, I don't specifically recall it, but I would say I undoubtedly did receive it." ${ }^{307}$ Consider also the response of Judge John Frazer:

Well, I presume that I received it. ... This is more than a year ago, but if it was sent out to all the Judges, I no doubt did receive it. . . I don't recall specifically all the letters that I received.

…

We have a mimeographed process in this Court, and I think I probably receive on an average of two, if not three, letters a day from Court, letters on different subjects. I just don't remember each letter, but I would say that I probably received that one. It seems to me that generally I remember some statement of that kind in a letter. ${ }^{308}$

The judges received many letters, perhaps too many to allow the careful consideration of each one. If a particular letter took a recognizable form, that alone probably conveyed sufficient information for the judges to

305. See id. at 637.

306. Id. at 641 (emphasis added).

307. Transcript, supra note 8 , at 369 .

308. Id. at 529. 
conclude that they knew its content. As Langer writes, " [I]nformation . . . is ignored because it is already known. It is known because it has been seen many times in the past, and aspects of its structure that regularly appear indicate that this time is just like the last." ${ }^{309}$

Some judges disregarded the court's directive to nominate persons from among all racial groups because cognitively, if not literally, the judges simply never saw it. The routine nature of the selection process ensured that they "understood" letters concerning that process without actually consciously considering them. Judges like Call and Frazer almost certainly testified honestly that they did not recall the letter that instructed them to pursue nomination practices starkly at odds with actual processes. It is unlikely that such judges consciously registered the content of those letters, decided to disregard them, and lied about their recollection on the stand. Rather, they routinely ignored the letters, just as they routinely nominated their acquaintances.

Judges Call and Frazer constitute something of an exception, however, as most judges did recall receiving the cross-section letter. ${ }^{310}$ Did those who remembered the letter decide to disregard it? On the contrary, they remembered the letter because they supposed that it confirmed the very practices they pursued. Although Langer doesn't explain this phenomenon, it follows neatly from her argument as well as from Zucker's. To the extent that certain structural clues trigger a scripted response, the whole script, with all of its component parts, becomes further entrenched. Each iteration further institutionalizes the script, so that the triggering of one part effectively puts into play the whole. ${ }^{311}$ Thus, the judges who "saw" the cross-section letter registered a reference to grand jury nomination practices, which in turn confirmed the "pick your friend" script. Without even reading the letter, they "knew" what it said: Continue in your current practices. This may seem a surprising claim, inasmuch as the cross-section letter instructed the judges to "be mindful of the need for making nominations from the various . . racial groups," a directive that the judges seemed decidedly not to be mindful of at all. Nevertheless, observe the following exchange between Acosta and Judge William Levit:

$Q$. Do you recognize the rule of law that says that the Grand Jury must be representative of a cross-section of the community?

$A$. I have no quarrel with that.

I would assume that with a hundred and thirty-four Judges, selected as they are and each one given the right to nominate up

309. Langer et al., supra note 263 , at 636 .

310. Sixteen judges recalled receiving the letter, while four did not. See Appendix C.

311. Cf. Robert P. Abelson, Psychological Status of the Script Concept. 36 AM. PSYCHOLOGIST 715, 717 (1981) ("The priming of one script event from a story leads to especially fast recognition of another script event from that story."). 
to two people, that this would be what I would consider a crosssection of the community, broadly defined. ${ }^{312}$

According to Judge Levit, selecting a cross section of the community, as the letter required, is exactly what the judges did. Judge Levit, like other judges, understood the thrust of the letter to commend rather than condemn the standard practice of picking one's friends. ${ }^{313}$

For many judges, nominating cohorts became so natural and appropriate a practice that they understood the presiding judge's admonition to do otherwise as an injunction to continue to do the same. For the judges, nominating one's friends constituted a powerful script. That they easily construed challenges to the script as support for it demonstrates in a remarkable manner the unconsidered and yet persistent nature of this routine.

\section{c. Legitimate Discrimination}

The Los Angeles superior court judges treated the "pick your friend" script as more than merely routine; they also embraced it as legitimate. Witness in this regard Acosta's questioning of two judges regarding whether they felt obligated to heed the presiding judge by seeking out a cross section of the community. Note that the first judge answered affirmatively and the second negatively, yet in the end, both insisted on the importance of picking one's acquaintances. Judge Benjamin Landis testified as follows:

Q. Do you believe that you personally have an obligation to make some affirmative effort to comply with this policy?

A. I think so.

312. Transcript, supra note 8 , at 596.

313. Consider also Acosta's questioning of Judge William B. Keene:

$Q$. Do you believe that the Grand Jury should be representative of a cross section of the community?

A. Yes.

$Q$. How do you define cross section?

$A$. I think you get a cross section by taking 134 Judges of all backgrounds, and having them nominate two, and from that group drawing by lot the total number that will serve.

Id. at 759-60. Judge Richard C. Fildew took a similar approach even when Acosta asked more pointedly about racial representation:

I just presume that, as the law leaves it to the Superior Court Judges to nomunate two nominees for the Grand Jury, and then they are picked out of a hat, as you know, and as the Superior Court should and does, I'm sure, represent a cross section of the community from the ethnic background we have, Japanese, well, we had a Japanese, we just lost him, on the Superior Court, he has gone to the [District Court of Appeals]. we have people of Mexican background, and then we have a few Mexicans that, when they got to the Superior Court, became Spanish, and-you know what I'm talking about-and we have Negroes, and so forth on this Court, that they were all nominating. we were all nominating, and you would get a cross section.

Id. at 649-50; see also id. at 453 (testimony of Judge Sidney W. Kaufman). 
Q. Have you ever taken such affirmative effort?

$A$. As to the seeking of people from various geographical areas, no, sir, I have not, because I don't know any.

$Q$. How about the different racial groups?

$A$. Or racial groups....

$Q$. How about "all economic levels"?

$A$. Well, people I recommended come from the upper strata. They are all well-to-do people, people who can afford to give-make a contribution to their community by serving on the Grand Jury.

$Q$. Did you ever contact any person or any organization for the purpose of finding nominees of Spanish surname?

A. No, sir. As I indicated heretofore, my personal conviction is that a Judge can't nominate anyone unless he knows them intimately, and I have never nominated anyone unless I know them fairly well..$^{314}$

Now the testimony of Judge Leonard A. Diether:

$Q$. Do you agree ... that each Judge must consider the different racial groups in making their nominations?

A. No, I don't. I think it is the duty of each Judge to pick a nominee who he feels is qualified for the position, regardless of what race, nationality, or religion he may be. It doesn't make any difference.

$Q$. Were any of your nominees of Spanish surname?

A. No.

$Q$. Were any of them of Mexican or Latin-American heritage?

A. No.

$Q$. Did you feel it was incumbent upon you in any way to seek out Spanish-surnamed persons?

A. No.

$Q$. Did you make any attempt whatsoever to seek such persons out?

A. No. No more than I would French, or Chinese, or Japanese, or Russian, or Catholics, or Protestants, or any other characteristic.

$Q$. Were any of your nominees Negroes?

A. No.

$Q$. Were any of your nominees Filipinos?

A. No.

$Q$. Or Orientals?

A. No.

$Q$. I believe you stated that all of your nominees were friends of yours.

A. That's right. 
$Q$. Would you nominate a person that was not personally known to you?

A. No, I would not. ${ }^{315}$

It seems fair to say that on the whole the judges possessed a deep commitment to the established practice of nominating their friends. Whether they claimed to agree with the cross-section requirement did not much matter. In the end, the judges ignored or misconstrued-or sometimes simply rejected-even relatively direct instructions to alter the standard practice. Consider a final exchange. Here, Acosta asks Judge Emmett E. Doherty whether he recalls the cross-section language in the presiding judge's letter:

$Q$. Do you recall the words in the letter... relating to representatives of a cross section of the community?

$A$. I never received any orders.

$Q$. Do you recall the letter?

$A$. I was never bound by anything more than my own discretion. ${ }^{316}$

Judge Doherty's responses are nonsensical, except as an expression of his commitment to business as usual. Asked only if he recalls the cross-section language, he responds by insisting on his autonomy in nominating grand jurors.

Peter Berger and Thomas Luckmann assert that "any radical deviance from the institutional order appears as a departure from reality." 317 For the judges put on the stand in East LA 13, the suggestion that they do otherwise than nominate acquaintances seemed to have that quality. Nominating grand jurors entailed selecting one's friends-and doing so became routine, legitimate, even rational. ${ }^{318}$ The presiding judge's challenge to this process could not be heard, or was heard but misunderstood, or agreed to but ignored, or simply repudiated. Meanwhile, the harder Acosta pushed, the more agitated the judges became. Acosta ultimately challenged not just a particular practice but the very identity of the judges as possessors of the discretionary power to name their acquaintances as grand jurors: In the end, he challenged reality, and reality is nothing if not routine and legitimate.

315. Id. at 519-20.

316. Id. at 330 .

317. BERGER \& LUCKMANN, supra note 14 , at 62.

318. "[D]ecision-making may appear rational merely because it follows the sociallyconstructed model of rational decision-making, independent of whether it actually involves any instrumental concern for optimizing substantive outcomes." Suchman, supra note 244, at 499. 


\section{B. The Persistence of the "Pick Your Friends" System and Path Discrimination}

Because the judges followed a script in nominating their friends, they gave their actions little or no thought, accepting them instead as routine and legitimate. Questioning by Acosta and the district attomey, however, compelled the judges called to the stand to consciously examine and defend the grand juror selection system. Similarly, though on a larger scale, the events and cases of the late 1960s and early 1970s, including the East Los Angeles cases, pushed the Los Angeles superior court judges to consider potential reform in their manner of selecting grand jurors. Even under relatively intense scrutiny, however, the Los Angeles judges continued to select their nominees as they had in the past. ${ }^{319}$ What explains the failure of the judges to undertake serious reform? Though inertia no doubt played a role, three predominant factors probably convinced the judges to continue with business as usual: racial animus, patronage of both the social and the political kind, and concern for the selection of "qualified" jurors.

This Section examines all three motives, though with special attention to the last. Most likely, racial animus and the interest in patronage were influenced by institutionalized understandings of appropriate conduct of the sort that path analysis depicts. The concern for qualifications, however, strikes a particular resonance with the judges' East LA 13 testimony. Whatever the judges' other rationalizations and motivations, the emphasis on finding qualified grand jurors reflects the operation of path institutionalism, both among the judges on the stand, and among the judges more generally in their decision not to reform their practices.

\section{Racial Animus}

Purposeful racism may have factored into the decision of some judges to retain personal control over juror selection. Although conscious racial antipathy has not been stressed here, it sometimes reared its head among the judges. For those judges who consciously held racially derogatory views, such views may have convinced them of the importance of close judicial control over the nomination of grand jurors, or, in any event, of the dangers of random selection.

To appreciate the degree of racism sometimes expressed among the judges, consider a transcript from a penalty hearing held before Santa Clara superior court judge Gerald Chargin in September 1969. The defendant, a seventeen-year-old Mexican-American boy, had pled guilty to the charge of incest with his fifteen-year-old sister, although he subsequently insisted that

319. See supra notes $145-151$ and accompanying text. 
he was innocent and had pled only on advice of counsel in order to avoid trial: ${ }^{320}$

The Court. Don't you know that things like this are terribly wrong? This is one of the worst crimes that a person can commit. I just get so disgusted that I just figure what is the use? You are just an animal. You are lower than an animal. Even animals don't do that. You are pretty low.

I don't know why your parents haven't been able to teach you anything or train you. Mexican people, after 13 years of age, it's perfectly all right to go out and act like an animal. It's not even right to do that to a stranger, let alone a member of your own family. I don't have much hope for you. You will probably end up in State's Prison before you are 25, and that's where you belong, any how. There is nothing much you can do.

I think you haven't got any moral principles. You won't acquire anything. Your parents won't teach you what is right or wrong and won't watch out.

Apparently, your sister is pregnant; is that right?

The Minor's Father, Mr. Casillas. Yes.

The Court. It's a fine situation. How old is she?

The Minor's Mother, Mrs. Casillas. Fifteen.

The Court. Well, probably she will have half a dozen children and three or four marriages before she is 18 .

The County will have to take care of you. You are no particular good to anybody. We ought to send you out of the country-send you back to Mexico. You belong in prison for the rest of your life for doing things of this kind. You ought to commit suicide. That's what I think of people of this kind. You are lower than animals and haven't the right to live in organized society-just miserable, lousy, rotten people.

There is nothing we can do with you. You expect the County to take care of you. Maybe Hitler was right. The animals in our society probably ought to be destroyed because they have no right to live among human beings. If you refuse to act like a human being, then, you don't belong among the society of human beings.

Mr. Lucero [Defense Counsel]. Your Honor, I don't think I can sit here and listen to that sort of thing.

The Court. You are going to have to listen to it because I consider this a very vulgar, rotten human being.

$M r$. Lucero. The Court is indicting the whole Mexican group.

The Court. When they are 10 or 12 years of age, going out and having intercourse with anybody without any moral training - they don't even understand the Ten Commandments. That's all. Apparently, they don't want to.

320. See Ruben Salazar, Judge's Latin Slurs Bring Call for Removal, L.A. Times, Oct. 2. $1969, \S 1$, at 1; see also RUBEN SALAZAR, BORDER CORRESPONDENT: SELECTEd WRITINGS 1955-1970, at 225-27 (Mario T. García ed., 1995) (providing further background on the incident). 
So if you want to act like that, the County has a system of taking care of them. They don't care about that. They have no personal self-respect.

Mr. Lucero. The Court ought to look at this youngster and deal with this youngster's case.

The Court. All right. That's what I am going to do. The family should be able to control this boy and the young girl.

Mr. Lucero. What appalls me is that the Court is saying that Hitler was right in genocide.

The Court. What are we going to do with the mad dogs of our society? Either we have to kill them or send them to an institution or place them out of the hands of good people because that's the theory-one of the theories of punishment is if they get to the position that they want to act like mad dogs, then, we have to separate them from our society.

Well, I will go along with the recommendation. You will learn in time or else you will have to pay for the penalty with the law because the law grinds slowly but exceedingly well. If you are going to be a law violator-you have to make up your mind whether you are going to observe the law or not. If you can't observe the law, then, you have to be put away. ${ }^{321}$

Judge Chargin's tirade from the bench, over the objections of defense counsel, stamped him as a racist. His commendation of Hitler, the easy manner with which he slipped back and forth between attacks on the accused and slurs on his family and the Mexican-American group as a whole, his dehumanizing language of animals and mad dogs, his calls for violence, including long incarceration, banishment, and extermination, all bespeak a mind poisoned by racial hatred.

To be sure, in the ferocity of his outburst, Judge Chargin was exceptional. Nevertheless, his views may not have been unique to him. Indirect evidence exists that his opinions did not deeply repel the bench: Despite the evident nature of his racism, and wide public airing of his rant, Judge Chargin was not removed from service as a superior court judge. ${ }^{322}$ If other judges shared even some of his views of Mexican Americans, such views may have contributed to their decision to retain discretion over the nomination of grand jurors. ${ }^{323}$

321. In re Paul Pete Casillas, Jr., No. 40331 (Cal. Super. Ct. 1969), reprinted in INTRODUCTION TO CHICANO STUDIES: A READER 482, $483-84$ (Livie Isauro Duran \& H. Russell Bernard eds., 1973).

322. In 1970, however, the Califomia Supreme Coun censured Judge Chargin, following the recommendation of the State Commission on Judicial Qualifications. See Judge Censured for Anti-Latin Remarks, L.A. TIMES, June 1 1, 1970. § 1, at 3.

323. See infra note 380. 


\section{Patronage}

Another possible factor contributing to the judges' decision to retain control over the selection of grand jurors may have been an interest in patronage, both social and political. Grand jury service carried with it a certain amount of prestige. As a 1966 Los Angeles grand juror marveled, "[Y]ou feel that you have some power and authority. You walk in the elevator and you get a certain kind of treatment. You walk down the hall and those that know you have a certain type of respect for you." ${ }^{324}$ Or as a 1962 Los Angeles grand juror enthused, "I enjoyed serving. I think it is the kind of sacrifice that virtually anybody can make. I am listed in every blue book and social directory although I am not a social type and it is always kind of a surprise to me when I am included." ${ }^{325}$ Along with picnics, barbecues, luncheons, and the flattering attention of county officials, grand jurors also received a lifetime parking pass at the downtown Los Angeles County courthouse and a fancy grand jury badge, possibly helpful in wiggling out of speeding tickets. ${ }^{326}$ And also, at least in Los Angeles, there beckoned membership in the Past Grand Juror's Association, a social club of approximately 200 people who had served at least one term on the grand jury. ${ }^{327}$ Given that grand jury service brought social prestige and a certain cachet, it should be no surprise that some judges viewed "grand jury service ... as an honor to be bestowed on citizens for outstanding public service or civic activity," while others used their nominating powers to "maintain their standing with the county's political influentials." ${ }^{328}$ This last factor may have carried particular significance, since California superior court judges were subject to reelection. ${ }^{329}$

\section{The Need for Qualified Grand Jurors}

The civil investigative function of the grand jury in California also served to justify the established procedures for the nomination of grand jurors. Recall that the San Francisco superior court advanced such an argument in federal court, claiming that "the civil investigative grand jury can and should be a so-called 'blue ribbon' panel." ${ }^{330}$ Or consider Judge Alarcon's explanation, given when he himself testified as a witness in the Sirhan Sirhan trial: ${ }^{331}$

324. EFFICIENCY AND ECONOMY, supra note 62, at 37 (testimony of Skipper Rostker).

325. Id. at 99 (testimony of Juanita Sayer Erickson).

326. See id. at 112-14.

327. See CRIMINAL PROCEDURE, supra note 104, at 44 (testimony of Howard Brace, foreman of the 1953 Los Angeles County grand jury).

328. Prahl, supra note 40 , at 639.

329. See ARNOLD, supra note 49, at 100.

330. Quadra II, 403 F. Supp. 486, 496 (N.D. Cal. 1975); see stura note 130 and accompanying text.

331. See People v. Sirhan, No. A-233421 (Cal. Super. Ct. 1969). 
Since the grand jury is required by law to perform an audit of the manner in which County moneys are expended, it seems to me to be necessary to nominate a Grand Juror of sufficient intelligence that he can read the audit report given to him by the contract auditor for the Grand Jury, can determine if the auditor has done a proper job, can require that the auditor make other investigations which were not covered by the audit, and this takes a great deal of sophistication and intelligence and I had that in mind when I tried to select someone for the Grand Jury. ${ }^{332}$

The contention that the demands of the civil investigative system required the careful selection of the most qualified grand jurors seems to have carried great weight with the judges. ${ }^{333}$ The strongest reason for retaining a subjective selection system may have been a conscious concern that grand jurors responsible for civil functions possess specific qualifications.

\section{The Nomination of Qualified Grand Jurors}

The judges' concern for qualified grand jurors reverberates throughout their testimony in East LA 13. No judge stated, for instance, that he intended to nominate his acquaintances. Instead, almost every one insisted that he had sought to nominate only the most qualified persons. In this context, recall the prosecutor's questioning of Judge Call, quoted almost in its entirety earlier in this Article. ${ }^{334}$ The district attorney asked not only whether there had been any purpose to discriminate, but also, "Did you nominate those persons whom you did in fact nominate because you felt they were the best qualified to serve?" ${ }^{335}$ Judge Call answered, "Absolutely." ${ }^{336}$ Here again, Judge Call's testimony anticipates that of the other judges. In response to similar questions, virtually every judge responded that he had nominated only those he considered "the best qualified to serve." Note that the judges' insistence on selecting the best qualified jurors did not come only in response to the prosecutor's direct prompting. Judge Call, for example, summarized his selection criteria by

332. Reporter's Transcript of Hearing on Motion to Quash Indictment at 2031. Sirhan (No. A-233421), quoted in Mar, supra note 48, at 44.

333. As one commentator observed,

California judges admittedly add their own qualifications to the state's statutory requirements-qualifications which have no relationship to the competency of a grand juror to listen to evidence and determine whether to indict, but rather are related to notions of competency needed for far more difficult duties in examining the operations of county government.

Mar, supra note 48, at 54. Grand jurors apparently also shared the sense that "high standards" had to be maintained. See Prahl, supra note 40, at 642 (reporing that 70\% of surveyed grand jurors "indicated that high selection standards should be maintained for the grand jury as opposed to the idea that any citizen is qualified to serve as a grand juror" ).

334. See supra note 152 and accompanying text.

335. Transcript, supra note 8 , at 400 .

336. Id. 
explaining, "It's a question if they have got the brains or capacity to be on the Grand Jury, is the whole thing in a nutshell. Very neatly stated." ${ }^{337}$ In justifying their nominations, the judges consistently claimed an intention to nominate "the best qualified." Qualifications emerged as a constant refrain in the testimony of the judges. ${ }^{338}$

\section{Path Discrimination}

In part, a desire to legitimate their activities in a context in which their motivations were under intense scrutiny may have compelled the judges to describe their practices as directed toward securing the best qualified grand jurors. No script told the judges how to respond to aggressive questioning on the stand, and no doubt the setting induced considerable conscious, purposeful, strategic thinking on the part of the judges. But the likelihood that they considered their answers carefully and tailored them to the setting does not mean that they lied outright. Rather, they probably believed that securing the best qualified in fact constituted their actual motivation. The legitimacy accorded their claim no doubt stems from our culture's celebration of merit. ${ }^{339}$ Its plausibility, however, especially to the judges themselves, must lie in their conviction that those they nominated actually constituted the best qualified. ${ }^{340}$ But how could they have thought this of their friends, their tennis buddies, their neighbors, and Camellia Club comembers? Path institutionalism offers an account of why the judges

337. Id. at $399-400$.

338. Consider the following remarks. "[I]t wouldn't make any difference who came before me if they are qualified as a nominee, but I don't want to nominate people I don't know." Id. at 393 (testimony of Judge Call) (emphasis added). "I think it is the duty of each Judge to pick a nominee who he feels is qualified for the position, regardless of what race, nationality, or religion he may be." Id. at 519 (testimony of Judge Leonard Diether) (emphasis added). "My primary motivation was to get the most qualified people, regardless of race, color, creed, or religion, or national origin." Id. at 556 (testimony of Judge Robert Feinerman) (emphasis added). "I think that if they are qualified Mexican-Americans, they should be selected . ..." Id. at 652 (testimony of Judge Richard C. Fildew) (emphasis added). "I would say that getting qualified people of various races is good." Id. at 493 (testimony of Judge Aubrey N. Irwin) (emphasis added). "[H]ad I known ... of anyone of a minority group who might have been qualified ... I would have gone out of my way to have appointed him ...." Id. at 457 (testimony of Judge Sidney W. Kaufman) (emphasis added). "It wouldn't make any difference what their ethnic background would be if I felt they were qualified to serve as Grand Jurors." Id. at 508 (testimony of Judge Ben Koenig) (emphasis added). "The only attempt I made, as I have indicated, was to select people whom I felt were qualified to serve, not on any basis of race, or religion, or nationality, anything like that." $I d$. at 597 (testimony of Judge William H. Levit) (emphasis added). "I went out to get the available people who I thought were the best qualified to serve as Grand Jurors . . ." Id. at 289 (testimony of Judge James G. Whyte) (emphasis added). See generally Appendix C.

339. See generally PRIVILEgE REVEALED: HOW INVISIBLE PREFERENCE UNDERMINES AMERICA (Stephanie M. Wildman ed., 1996).

340. "[W]hen people are asked to attribute the causes of actions or choices, they do not actually examine their cognitive processes, but select from memory a causal theory which scems to them to be a plausible explanation for what they have done." Krieger, supra note 227, at 1215 (emphasis added) (citing Richard E. Nisbett \& Timothy DeCamp Wilson, Telling More than We Can Know: Verbal Reports on Mental Processes, 84 PSYCHOL. REV. 231. 247 (1977)). 
uniformly claimed to be interested in nominating the best qualified, even as they nominated their friends.

The pressures for reform and the demands of the East Los Angeles cases forced the judges to abandon the security of a routine script and to consciously consider their nomination practices. However, the Los Angeles superior court judges were not thereby free from institutional influences. Rather, even as they carefully weighed their responses, they continued to draw on institutionalized understandings. That is, they exercised conscious thought along the paths laid out for them by institutions. "[T]acit cultural assumptions ... fram[e] behavior at a preconscious level.... [T] he most important determinants of decision-making may be neither costs and benefits nor moral principles, but rather, the taken-for-granted cultural categories, definitions and accounts that help us to make sense of our lives." 341 Tacit cultural assumptions about racial animus and political and social patronage most likely informed the judges' reliance on those motivations. Certainly, invoking the need for "qualified grand jurors" seemed to operate in this fashion for the judges.

Reciting a concern for qualification sufficed in the judges' (and prosecutors') minds to clothe the judges' actions with a mantle of legitimacy, and to dispel doubts about the appropriateness of their conduct..$^{342}$ Notice that no judge made more than a modest effort to give that term any content in his testimony. Notice also that no judge described a selection system rationally geared to identifying and selecting the most qualified persons. Yet, notwithstanding these failures, almost all judges repeatedly cited the importance of qualifications. Path institutionalism suggests that the very thinness of the term as used by the judges facilitated rather than detracted from the ability of qualification to serve as a multifaceted justificatory tool. "Classifications, logical operations, and guiding metaphors are given to the individual by society. Above all, the sense of a priori rightness of some ideas and the nonsensicality of others are handed out as part of the social environment." ${ }^{343}$ For the judges, to invoke the pursuit of "qualified" grand jurors spoke volumes in the judges' world exactly because the term put into play widely shared but unarticulatedand, indeed, largely nonconscious-understandings of who should sit on grand juries. The need for "qualified" grand jurors was imbued with a priori rightness that ensured that this rationale would appear weighty and legitimate, even as it served only to justify the judges' actions by reference to their shared but unrecognized consensus on appropriate selection practices.

341. Suchman, supra note 244 , at 482 .

342. Cf. BERGER \& LUCKMANN, supra note 14, at 23 (describing "[c]ommonsense knowledge" as "the knowledge I share with others in the normal, self-evident routines of everyday life").

343. DOUGLAS, supra note 1 , at 10. 
In East $L A 13$, the judges relied on the rhetoric of "qualified grand jurors" to defend their past nomination practices. Qualifications also figured prominently as a justification for continuing the "pick your friends" selection system. Script institutionalism underlies the judges' unthinking exclusion of Mexican Americans in the years before the East Los Angeles cases. Path institutionalism rationalized those practices in the minds of the judges, and perpetuated such practices in the decades that followed.

\section{INSTITUTIONAL RACISM}

In East LA 13 and Biltmore 6, Judges Kathleen Parker and Arthur Alarcon rejected the defendants' discrimination claims and granted legal legitimacy to the superior court judges' established nomination practices. In retrospect, for them to have held to the contrary would have been virtually inconceivable, for most likely both Judges Parker and Alarcon engaged in the decried practices. ${ }^{344}$ Nevertheless, their rulings declared under law's imprimatur that the judges' selection of their friends did not constitute "racial discrimination."

But were Judges Parker and Alarcon wrong? Even if we assume script and path institutional influences on the judges' actions, what converted such actions into racial discrimination? One can answer this question in terms of effects. ${ }^{345}$ To appreciate fully the claim that nothing less than institutional racism occurred, however, one must reexamine the judges' practices in light of what I term racial institutions. In this Part, I develop the notion of racial institutions, and then provide a typology that distinguishes between purposeful and institutional racism. Considering afresh the judges' actions, I utilize the concept of racial institutions to illustrate how the judges' script and path behavior amounted ultimately to script and path institutional racism.

\section{A. Racial Institutions and Unconscious Racism}

Racial beliefs suffuse our society, and many if not most of these beliefs operate as racial institutions. That is, they constitute unconsidered understandings of race-taken-for-granted, consistently relied on, and disrupted, if at all, with great difficulty. Social actors both inherit and remake racial institutions, which ultimately depend upon group dynamics for their perpetuation. Of course, institutionalization does not result in monolithic or static understandings of race. Racial institutions take many

344. Cf. Linda Hamilton Krieger, Civil Rights Perestroika: Intergroup Relations After Affirmative Action, 86 CAL. L. REV. 1251, 1328 (1998) (noting that "[t]here is no reason to believe that the incidence of stereotype-induced judgment error in discrimination adjudications will differ in any significant way from its incidence in employment or educational decision making").

345. See supra Section II.F. 
forms and function differentially across various domains. Some racial institutions, such as those regarding the virtues of Whites, operate in diverse forms across geography, time, and social groups; others, such as beliefs regarding Mexican Americans, remain more restricted in structure and more specific to certain places and eras. For all this heterogeneity, however, race constitutes a paradigmatic set of institutions. Mary Douglas speculates that socially ordering ideas undergo institutionalization when they refer back to or claim a mandate in nature:

[T]he incipient institution needs some stabilizing principle to stop its premature demise. That stabilizing principle is the naturalization of social classifications. There needs to be an analogy by which the formal structure of a crucial set of social relations is found in the physical world, or in the supernatural world, or in eternity, anywhere, so long as it is not seen as a socially contrived arrangement. When the analogy is applied back and forth from one set [of] social relations to another and from these back to nature, its recurring formal structure becomes easily recognized and endowed with self-validating truth. ${ }^{346}$

Surely ideas of race epitomize this process, for in the Southwest and in the United States generally, the history of race amounts to the history of ascribing social relations to nature.

The claim that racial institutions permeate society bears an important resemblance, and a great debt, to Charles Lawrence's writings on unconscious racism. ${ }^{347}$ Published more than a decade ago and widely regarded as one of the foundational Critical Race Theory articles, Lawrence's The Id, the Ego, and Unconscious Racism argued that racial stereotypes suffuse American society and psyches. "Americans," Lawrence wrote, "inevitably share many ideas, attitudes, and beliefs that attach significance to an individual's race and induce negative feelings and opinions about nonwhites. To the extent that this cultural belief system has influenced all of us," he continued, "we are all racists." ${ }^{318}$ Lawrence's claim that "we are all racists" caused a considerable stir. Yet, if one

346. DougLAS, supra note 1 , at 48 .

347. See Lawrence, supra note 30.

348. Id. at 322. Lawrence spells out his argument in the following oft-quoted paragraph: Americans share a common historical and cultural heritage in which racism has played and still plays a dominant role. Because of this shared experience, we also inevitably share many ideas, attitudes, and beliefs that attach significance to an individual's race and induce negative feelings and opinions about nontwhites. To the extent that this cultural belief system has influenced all of us, we are all racists. At the same time, most of us are unaware of our racism. We do not recognize the ways in which our cultural experience has influenced our beliefs about race or the occasions on which those beliefs affect our actions. In other words, a large part of the behavior that produces racial discrimination is influenced by unconscious racial motivation.

Id. (footnotes omitted). Other critical race theorists also urge a focus on the dynamics of unconscious racism. See, e.g., Jody Armour. Stereonpes and Prejudice: Helping Legal Decisionmakers Break the Prejudice Habit, 83 CAL. L. REV. 733 (1995): Davis, supra note 30. 
understands him to claim that racial beliefs widely pervade society, shaping behavior at a nonconscious level, I advance the same argument in this Article.

Nevertheless, important theoretical differences distinguish Lawrence's approach from my own. Most importantly, Lawrence rested a substantial portion of his argument on Freudian grounds. ${ }^{349}$ This reliance produced an ambiguous methodological focus, wherein the careful examination of social practices rubbed uneasily against strong claims about individual psychological dynamics. In contrast, I do not attribute racial institutions to the idiosyncratic psychology of individuals. Instead, I posit that group interaction generates racial institutions, and that such institutions influence individual behavior through widely shared cognitive processes. The cultural practices occurring in specific social and organizational settings are precursors to institutionalization; institutions form as the habits of groups, not individuals. In turn, racial institutions do not inform action through the relatively hot, relatively stochastic processes of egotistical turmoil and repression, but through the cooler dynamics of standard cognitive distortions. It is not that individuals struggle to reconcile conflicting values and thoughts, but that congeries accede to accepted manners of thinking and acting. To be sure, institutional and Freudian processes do not exclude one another-one might engage in both unconscious racism of the sort Lawrence described and institutional racism of the type I postulate. These processes, however, remain theoretically distinct.

With this clarification in mind, it bears repeating what the notions of racial institutions and unconscious racism share: an assertion that nonconscious racial beliefs permeate society. When people absorb and rely on racial ideas cognitively, treating race as an accepted, expected part of the natural order, race functions institutionally. A racial institution is any understanding of race that has come to be so widely shared within a community that it operates as an unexamined cognitive resource for understanding one's self, others, and the-way-the-world-is. To restate in institutional language Charles Lawrence's observation that "we are all

349. Although Lawrence gives substantial attention to cognitive psychology, see Lawrence, supra note 30 , at $323,336-39$, he emphasizes a Freudian approach in his article, arguing that the desire to avoid feelings of guilt associated with racial animus leads the conscious mind to suppress such animus where it cannot defeat it, see id. at 323 ("When an individual experiences conflict between racist ideas and the societal ethic that condemns those ideas, the mind excludes his racism from consciousness."). Others, such as Joel Kovel, have also pursued a Freudian approach at some length. See JOEL KOVEL, WhITE RACISM: A PSYCHOHISTORY (1970). Psychoanalytic theories of racism continue to have contemporary resonance. See, e.g., PAUL L. WACHTEL, RACE IN THE MIND OF AMERICA: BREAKING THE VICIOUS CIRCLE BETWEEN BLACKS AND WHITES (1999). Indeed, this approach undergirds the renascent "aversive racism" thesis, which posits that Whites experience anxiety and discomfort (rather than overt hostility) in the presence of minorities because of a conflict between consciously held egalitarian norms and unacknowledged racial biases. See Kovel, supra, at 191-211; see also Samuel L. Gaertner \& John F. Dovidio, The Aversive Form of Racism, in PREJUdICE, DISCRIMINATION, AND RACISM 61 (John F. Dovidio \& Samuel L. Gaertner eds., 1986). 
racists": In this country we are all constituted by and cognitively rely on racial institutions.

\section{B. Racism}

An explicit discussion of racism, one that both defines and disaggregates that term, is now in order.

\section{A Definition}

I define racism as follows: Racism is racial status-enforcement undertaken in reliance on racial institutions. ${ }^{350}$ Notice that this definition effectively has three components. The third, "racial institutions," I have just defined as "any understanding of race that has come to be so widely shared within a community that it operates as an unexamined cognitive resource for understanding one's self, others, and the-way-the-world-is." The second, "undertaken in reliance," involves the relationship between cognitive processes and racial institutions, and is the primary focus of this Part, as it highlights the distinction between institutional and purposeful racism. Before proceeding to that discussion, however, the notion of racial status-enforcement merits review, both as an essential component of the proffered definition of racism, and as an important factor in the decision to label as "racism" the discriminatory practices described in this Article.

Under the definition of racism advanced above, neither racial statusenforcement nor a reliance on racial institutions alone amounts to racism. Some actions may enforce status hierarchies and yet not be impelled directly or indirectly by reliance on racial institutions. ${ }^{351}$ And some actions may be driven by reliance on racial institutions and yet not enforce racial status. ${ }^{352}$

350. This definition is slightly overinclusive with respect to purposeful racism. See infra note 377. While this definition seeks to describe accurately a set of common social practices that harm racial minorities, it nevertheless also attempts to highlight elements of the discrimination theory advanced here. Some distance separates these goals, as one aims al descriptive accuracy regarding a widespread phenomenon, while the other auempts to clarify a theory concemed with just one part of that phenomenon. In addition, with regard to descriptive accuracy, this definition of racism applies only in the contemporary socio-historical seting, describing the contours of racism in the post-civil rights era just beginning in the late 1960 s and now deeply entrenched in the 2000 s. See MiCHAEl OMI \& HOWARD WINANT, RAClal Formation IN THE UNTIED STATES: From tHE 1960S TO THE 1990S, at 71 (2d ed. 1994) (“[T]here can be no timeless and absolute standard for what constitutes racism ....").

351. For example, distinctions made on wealth in this country, if independent of all motivations related to race, might be of this sor. However, the likelihood is that virtually all discriminatory action in this country is tied in at least an attenuated manner to meial institutions. See infra notes 398-399 and accompanying text.

352. Public initiatives to counteract racial hierarchy-for instance, antidiscrimination laws and affirmative action programs-do not constitute racism under this definition, despite outright reliance on racial institutions. 
"Racial status-enforcement" refers to action that has the effect of enforcing a racial status hierarchy. ${ }^{353}$ Action here is an important element, directing attention to individual behavior-albeit individual behavior in group contexts-and not to abstract social processes divorced from social actors. Such action forms a predicate to racism insofar as it consists of cultural practices of racial status-based differentiation. I emphasize here the symbolic "status conflicts [that] occur when groups clash... over the approval, respect, admiration, or deference that they are able to command by virtue of their way of life, including their culture, customs, and values." ${ }^{354}$ But I also emphasize the material and structural components of social domination - the market marginalization and public-sector alienation attendant upon racial oppression. ${ }^{355}$ Status-enforcement may enhance or degrade a racial group's social position and may take material or symbolic forms. ${ }^{356}$

Concern for racial status-enforcement motivates the decision to describe as racism the discriminatory practices examined in this Article. Racial status-enforcement directs attention to the harms suffered by minority communities. To the extent that harm constitutes a central measure of racism, institutional practices more than qualify. Institutional practices impose substantial injuries on minorities, even if they do so quietly, in a matter-of-fact, taken-for-granted manner. Moreover, as this Part details, institutional processes inflict such harms on minorities because of, not despite, their minority status. In this way, harmful institutional action corresponds closely to the common understanding of racism-deleterious

353. Cf. supra note 186 (citing works by Jack Balkin, Reva Siegel, Kenneth Karst, and Rachel Moran that also root conceptions of social domination in a status model). George Fredrickson similarly focuses on status in defining racism:

Racism ... can be defined as an ethnic group's assertion or maintenance of a privileged or protected status vis-à-vis members of another group or groups who are thought, because of defective ancestry, to possess a set of socially-relevant characteristics that disqualify them from full membership in a community or citizenship in a nation-state.

George M. Fredrickson, Reflections on the Comparative History and Sociology of Rucism, in RACIAL ClASSIFICATION AND HISTORY 51, 55 (E. Nathaniel Gates ed., 1997).

354. Moran, supra note 186 , at 341.

355. Cf. Lucius Outlaw, Toward a Critical Theory of "Race," in ANATOMY OF RACISM 58 , 69-70, 74-75 (David Theo Goldberg ed., 1990) (discussing the importance of analytically linking the "cultural, political, and economic structural and dynamic features of the social world in assessing racism"). Consider also john a. powell's vision of a post-civil-rights agenda:

The post-civil rights agenda must focus on subordination and exclusion. The key to this focus is understanding that racial discrimination and economic deprivation are not only oppressive, but they are also structural and institutional. Without characterizing oppression as structural, and without developing an agenda that is oriented toward destabilizing and disturbing this structure, any formal or individual progress will be largely rendered impotent ....

john a. powell, An Agenda for the Post-Civil Rights Era, 29 U.S.F. L. Rev. 889, 910 (1995).

356. A status model complements an institutional approach to racism, as both direct attention to group dynamics. Some tension exists, however, between a status approach and an institutional one, as status theory implies a level of rational or strategic action. The status-enforcement requirement in my definition should not be read as an effort to reinsert an interest in motives, but rather seen as a desire to inject a concern for outcomes. 
treatment imposed on the basis of racial group identity. All social action to some degree or another draws on institutions, and frequently on racial institutions. Under my definition, action influenced by racial institutions becomes "institutional racism" when those actions produce racial status harms. Notice, however, that the theory of institutional discriminatory behavior advanced here does not depend on its definition as "racism." Whether one accepts or rejects the "racism" label, the validity of the racial discrimination model advanced in this Article must be evaluated on its own terms.

\section{A Typology}

The definition of racism proffered above takes a specific form: racial status-enforcement, plus some cognitive process tied to racial institutions. The following typology builds on this form to distinguish purposeful from institutional racism, and further, to divide institutional racism into script and path varieties.

Purposeful racism is directed racial status-enforcement motivated by an intent to discriminate harmfully.

Institutional racism is directed or undirected racial statusenforcement influenced in an unrecognized manner by racial institutions.

Institutional racism divides into path and script racism:

Path racism is directed racial status-enforcement influenced in an unrecognized manner by racial institutions.

Script racism is undirected racial status-enforcement influenced in an unrecognized manner by racial institutions.

The remainder of this Part explores these distinctions. However, for purposes of clarity, consider the following quick sketch. Given racial statusenforcement, three labels are possible: purposeful racism, institutional racism, and no racism. Purposeful racism obtains when the status-enforcing action stems from a consciously embraced desire to discriminate. No racism occurs if racial institutions play no role in generating racial statusenforcement. Institutional racism exists if such action results from an unrecognized reliance on racial institutions. Within the category of institutional racism, a further division may be made: Undirected action constitutes script racism, whereas directed action may be described as path racism. 


\section{Racial Institutions in Los Angeles}

Let us now apply the notions of racial institutions and racism to the Los Angeles superior court. Los Angeles at the close of the 1960s swirled with stereotypes of the various social groups making up the county. Many of these stereotypes, in turn, operated as institutions-cognitive shortcuts, encompassing shared yet unrecognized renditions of reality. As social actors operating within Los Angeles, the superior court judges drew on those institutions. They may have done so purposefully, or they may have struggled consciously against racism. Either way, racial institutions informed their social judgments at a nonconscious level.

Consider the judges' actions in nominating their friends. The institutional scripts and paths the judges followed-for example, the automatic recourse to selecting acquaintances or the casual but consistent invocation of qualifications-did not draw on race explicitly. Nevertheless, these scripts and paths incorporated at unexamined levels significant racial components. Taken-for-granted understandings of both White and Mexican-American identity, operating in the form of racial institutions, penetrated the Los Angeles superior court judges' ostensibly race-neutral institutionalized behavior. Racial institutions did not, however, influence the judges' behavior in an ad hoc or idiosyncratic fashion. Instead, racial institutions operated on the judges through standard mental dynamics and heuristics. The judges followed institutionalized patterns of behavior generated at an organizational level, and racial institutions in turn informed those patterns through standard cognitive distortions that almost uniformly affected all judges. ${ }^{357}$

357. Social and cognitive psychology figure prominently and helpfully in assessing how racism infused the judges' actions, though the analytic emphasis remains on institutionalized group dynamics. Psychology in general, and cognitive theory in particular, nicely dovetail with New Institutionalism. New Institutionalism has incorporated cognitive psychology's emphasis on schemata, unacknowledged, privately held, substantive mental shortcuts akin to, or in some circumstances synonymous with, “institutions." See Suchman \& Edelman, supra note 23, at 910. On schemata, see, for example, David E. Rumelhart, Schemata and the Cognitive System, in 1 HANDBOOK OF SOCIAL COGNITION 161 (Robert S. Wyer, Jr. \& Thomas K. Srull eds., 1984). Some New Institutionalists have also adopted cognitive psychology's insights into heuristics: standard cognitive operating procedures or processes not subject to motivational effects. See, e.g., Theresa K. Lant \& Joel A.C. Baum, Cognitive Sources of Socially Constructed Competitive Groups, in THE INSTTIUTIONAL CONSTRUCTION OF ORGANIZATIONS, supra note 245, at 15. On heuristics, see, for example, Amos Tversky \& Daniel Kahneman, Judgment Under Uncertainty: Heuristics and Biases, in JUDGMENT UNDER UNCERTAINTY: HEURISTICS AND BIASES 3, 18 (Daniel Kahneman et al. eds., 1982). Despite this synergy, important differences exist between New Institutionalism and cognitive psychology. Of perhaps greatest importance, whereas cognitive psychology addresses the operation of cognitive distortions in individuals, New Institutionalism takes as its focus organizational structures and, to a lesser degree, the influence of organizational contexts on individual behavior. Of less importance, but still of significance, while cognitive psychology emphasizes widespread, not to say universal, cognitive phenomena, New Institutionalists highlight culture and context. Nevertheless, cognitive psychology informs an institutional analysis of racism. In this regard, the scholarship of my colleague Linda Krieger stands out, for she more than anyone has focused on the hard lessons that cognitive psychology teaches about racial discrimination and law. See Krieger, supra note 344; Krieger, supra note 227. 


\section{Judicial Discrimination}

\section{Script Discrimination}

The judges followed a simple script in nominating grand jurors: They turned to their acquaintances. Yet racial group identity strongly influenced whom the judges knew. Social psychology's analysis of intergroup biases explains the root of this dynamic. Substantial evidence demonstrates that people treat others whom they perceive as like themselves far more favorably than they treat persons whom they consider socially distinct. ${ }^{358}$ These intergroup effects function substantially automatically, at a level of cognitive processing that actors do not consciously control or even perceive. Though the biases operate in a standard fashion, however, they remain rooted in contingent notions of group identity and difference. Racial institutions often provide the basis for group distinctions.

\section{a. Favoring Whites}

The judges' penchant for nominating acquaintances amounted to tapping persons they likened to themselves. Consider a composite offered by Acosta of the typical Los Angeles grand juror:

From the testimony of the thirty-three judges subpoenaed to testify [in East LA 13], at times vague if not downright hostile, a reasonable composite of the 1959-1969 "grand juror" was constructed: (1) He is comparatively advanced in years. (2) He is wealthy, of independent financial means. (3) $\mathrm{He}$ is, or was, a business owner, executive, or professional-or married to one. (4) $\mathrm{He}$ is a close personal friend, occasionally once removed, of a Superior Court Judge. (5) $\mathrm{He}$ is White.... In a word, as characterized by an appellate Judge: WASP. ${ }^{359}$

Although Acosta set out to describe grand jury nominees, he effectively described the judges themselves. Every superior court judge shared most of the listed characteristics, and many possessed them all: mature in age,

358. See generally RUPERT BROWN, PREJUDICE: ITS SOCIAL PSYCHOLOGY 8 (1995) (defining prejudice as "the holding of derogatory social attitudes or cognitive beliefs, the expression of negative affect, or the display of hostile or discriminatory behavior towards members of a group on account of their membership in that group"); JAMiES M. JONES. PREJUDICE AND RACISM (1972) (discussing the role of psychological distinctions based on race as perpetuating prejudice). According to Krieger, "A substantial body of work on intergroup behavior, representing over thirty years of empirical research, demonstrates that once divided into groups, even on a trivial or random basis, people exhibit powerful intergroup biases." Krieger, supra note 344, at 1274. Strikingly, Richard McAdams's status-production article relies on some of this same research, though he makes little of its provenance. See McAdams, supra note 35, at 1013-16.

359. Oscar Zeta Acosta, The East LA. 13 vs. The LA. Superior Court. El GRITO, Winter 1970 , at 12,15 . 
wealthy, professional, male, and White. Charged with the duty to pick grand jurors, the judges picked persons similar to themselves.

Racial institutions operated through in-group favoritism to inform the Los Angeles superior court judges' nominating practices. Such institutions incorporated not only negative beliefs about minority groups but also favorable presumptions about Whites. ${ }^{360} \mathrm{~A}$ large literature now centers on the cultural significance of White identity. ${ }^{361}$ This cultural significance extends to the cognitive level, where a positive conception of Whiteness functions as a default position. Thus, in striking up friendships and in nominating grand jurors, the judges drew on assumptions of White social worth and respectability. Some may have done so consciously. Regardless of their decision to rely on or to reject racial considerations, however, every judge on the superior court drew on notions of White superiority at the nonconscious level.

The judges followed a script of nominating acquaintances. Yet racial institutions concerning the superiority of Whites helped to draw lines around the judges' social worlds. How they thought of themselves and who they thought to be in-group members turned substantially on notions of White identity. The infusion of race into the grand jury nomination practice did not exclusively take the form of negative racial ideas. Primarily, perhaps, it took the form of in-group prejudice in favor of Whites. ${ }^{362}$

\section{b. Disfavoring Mexican Americans}

But of course, notions of Mexican-American identity also played a role. Irrespective of their level of consciously held prejudice, the superior court judges harbored notions of Mexican-American inferiority. ${ }^{363}$ Moreover, such notions came into play easily, possibly simply through exposure to

360. A recent study used response time in word-recognition tasks as a measure of the degree of association between racial categories and various positive and negative trait constructs. This study found that even "low prejudiced" individuals "readily associate[d] positive traits with whites." Samuel L. Gaertner \& John P. McLaughlin, Racial Stereotypes: Associations and Ascriptions of Positive and Negative Characteristics, 46 SOC. PSYCHOL. Q. 23, 24 (1983). Krieger summarizes other studies demonstrating White in-group biases. See Krieger, supra note 344 , at $1322-24$.

361. See generally ALLEN, supra note 198; DISPLACING WHITENESS: ESSAYS IN SOCIAL AND CULTURAL CRITICISM (Ruth Frankenberg ed., 1997); RUTH FRANKENBERG, WHITE WOMEN, RACE MATTERS: THE SOCIAL CONSTRUCTION OF WHITENESS (1993); HANEY LóPEZ, supra note 7; TONI MORRISON, PLAYING IN THE DARK (1992); OFF WHITE: READINGS ON RACE, POWER AND SOCIETY (Michelle Fine et al. eds., 1997); DAVID R. ROEDIGER. TOWARDS THE Abolition of Whiteness (1994); Alexander SaXton, The Rise and Fall of the White REPUBLIC (1990).

362. Cf. Krieger, supra note 344 , at 1319 (" [In-group favoritism] largely underlies the kind of discrimination that results in the systematic advantaging of white males.").

363. According to Lawrence's theory, no judge conversant with the culture of California at the time could have failed to be influenced by ideas of Mexican-American inferiority. Stercotypes of degeneracy concerning the Mexican-American community continued to thrive in the late 1960s. See, e.g., supra notes 320-323 and accompanying text (remarks of Judge Gerald Chargin). 
Spanish surnames. ${ }^{364}$ Through the processes of in-group favoritism, not only nonconscious presumptions of White worth but also unconsidered conceptions of Mexican-American worthlessness influenced the judges' nomination patterns.

Some judges, of course, claimed to know a few Mexican Americans. Did their familiarity with members of that community shield them from the prejudices that plagued their colleagues? Probably not. Consider in this context the fundamental attribution error, the tendency of persons to overattribute the behavior of others to dispositional traits rather than to situational factors. ${ }^{365}$ Those judges who claimed Mexican-American acquaintances most often named gardeners and servants. ${ }^{366}$ If the attribution-error heuristic held true, however, those judges most likely attributed the menial or servile position of their acquaintances not to social status but to Mexican-American "nature." ${ }^{367}$ The judges' considerable distance from the Mexican-American community in East Los Angelesgeographically as well as socially-facilitated reliance on racial institutions regarding Mexican Americans. Most judges did not "know" Mexican Americans at all, except in terms of the racial institutions concerning that group. Some judges did, however, possess a few Mexican-American acquaintances. Paradoxically, though, because those judges knew Mexican Americans only as gardeners and servants, they most likely "knew" Mexican Americans not less but even more deeply in terms of the racial institutions surrounding that group.

364. A recent study demonstrates that exposure to names such as Jane and John significantly alters the judgments subjects make about otherwise unknown persons. See Mahzarin R. Banaji et al., Environments and Unconscious Processes, in 10 ADVANCES IN SOCIAL COGNITION 63. 69-7! (Robert S. Wyer, Jr. ed., 1997). Reflecting on their findings, the study's authors commented: "What is remarkable is the smallness of the familiarizing experience an environment must offer (in this case, passing exposure with a name ...) to show an effect on judgment." Id. at 70. They concluded, "People are universally influenced by sociocultural noms that engender stereotyping of and prejudice toward members of social groups. ... IT]riggers may be socially microscopic, shaping social cognition without awareness and acknowledgment." Id. at 69.

365. See Lee Ross, The Intuitive Psychologist and His Shortcomings: Distortions in the Attribution Process, in 10 ADVANCES IN EXPERIMENTAL SOCIAL PSYCHOLOGY 173 (Leonard Berkowitz ed., 1977); see also Krieger, supra note 344, at 1329 (“IT)he fundamental attribution error... leads people to over-attribute social behavior to stable. dispositional traits and to underestimate the causal efficacy of situational determinants of judgment, behavior, and choice.").

366. See, e.g., supra note 74 and accompanying text.

367. Consider the following argument:

It is precisely the confounding of person and situation that allows people to be well served by their naive dispositionism. When we predict that the behavior of professors will be professorial, that the behavior of dictators will be dictatorial, or that the behavior of servants will be servile... the performances we observe more often than not will confirm our predictions and justify the relevant trait ascriptionprofessorial, dictatorial, or servile-provided, of course. that we continue to observe the actors in circumstances where the privileges and constraints of their roles remain in effect....

LEE ROSS \& RICHARD E. NISBEtT, THE PERSON AND the SITUATION: PERSPECtives Of SOCIAL PSYCHOLOGY 150 (1991). 
The judges' nomination of their friends amounted to racial discrimination not only because of its racial effect, but also because racial institutions infused that selection system. The nomination script's discriminatory effect followed from that script's substantial incorporation of racial institutions. Reliance on racial institutions transformed the judges' otherwise race-neutral practice of picking their friends into a racially discriminatory system of nominating White persons and excluding Mexican Americans.

\section{Path Discrimination}

The attention focused by the East Los Angeles cases on the judicial practice of nominating friends made it difficult for the judges to continue that practice thoughtlessly. Put differently, those cases and other contemporaneous events interrupted the judges' easy subscription to a nomination script. Nevertheless, by asserting the importance of selecting "qualified" grand jurors, the judges both defended their past conduct and justified its continuation. Recourse to the language of qualifications in this context constituted path discrimination, and ultimately, path racism.

The judges consistently returned to a discourse of "qualifications." This language, however, carried with it a strong racial subtext: Qualified persons were White, and nonwhites were unqualified. Consider Acosta's questioning of a judge regarding whether minorities should sit on grand jury panels:

$Q$. Do you believe that the Grand Jury should be represented by the different racial and ethnic groups?

$A$. If the people are qualified, definitely; if they are not qualified, no.

Q. I'm talking about the ultimate result, the end result.

$A$. I answered you; I said if they are qualified.

If the end result is you are getting unqualified people on there, my answer would be definitely no. ${ }^{368}$

Acosta attempted to set the "qualified" issue aside:

Q. I am assuming that the Grand Jury is eventually composed of qualified people.

Now, my question is: Do you believe that the ultimate result of any Grand Jury should be that it be composed generally of a cross section of the community?

A. It would be fine if it could, and I will agree with that, that it would be very nice if it could, but if you are going to impair the 
quality and get on people just because they are of certain races, then I am not in favor of that. ${ }^{369}$

Here, Acosta apparently grew frustrated with the judge:

$Q$. What do you mean by "impair the quality" by certain people? I don't-

A. Well, if you are going to get somebody who isn't qualified just because he is an American-Indian or an Eskimo, because you have to have an Eskimo on the Grand Jury, but this fellow isn't qualified, I am against that. I don't think the Grand Jury should be composed of people like that. ${ }^{370}$

Notice that for this judge, whether to include a cross section of the community relentlessly reduced to an issue of qualifications. Many judges inextricably but nonconsciously linked qualifications with racial identity.

The representativeness heuristic helps to explain this unrecognized but virtually unseverable link between race and qualifications. This heuristic describes how persons assign others to categories-for instance, the category of "grand jurors." Persons do not carefully scrutinize the other and compare her characteristics against exactly assembled criteria for category membership. Instead, they contrast those aspects of the other perceived as salient against facets of the category that stand out. ${ }^{371}$ Put differently, under this heuristic, social actors rely on institutions twice when they match persons and groups: Institutions factor in how they assess the salient characteristics of others, and again in how they assess categories.

The impact of racial institutions on evaluations of persons has been discussed in terms of script discrimination. ${ }^{372}$ Note here that the representativeness heuristic describes how racial institutions also informed conceptions of the "grand juror" category. In seeking nominees, the judges developed a stock conception of a "grand juror." This accepted account reflected the most socially salient aspects of the identity of those nominated in the past, thereby building past racism into ongoing evaluations of typicality. But it also drew freshly on racial institutions concerning social respectability and competence. ${ }^{373}$ On both of these levels, racial institutions concerning Whites and Mexican Americans figured prominently in the judges' conception of the prototypical "grand juror."

The representativeness heuristic helps explain the judges' persistence in nominating friends and neighbors even after they were challenged about

369. Id.

370. Id. at 653-54.

371. See Tversky \& Kahneman, supra note 357, at 49-57.

372. See supra notes 360-367 and accompanying text.

373. For a more detailed examination of the cognitive influence of race on evaluations of merit, see Krieger, supra note 344, at 1291-302. 
their practices. Unable to rely on a script, the judges nevertheless relied on an institutionalized understanding of "grand juror" to conceptualize their actions. Racial institutions functioned through the representativeness heuristic to create an unexamined certainty that the best qualified grand jurors consisted of the judges' (White) friends. Only in this way could the "best qualified" serve as a legitimate explanation for the judges' practice of nominating almost exclusively White grand juries. Racial institutions and the representativeness heuristic assured the judges that the best qualified grand jurors were White.

According to the same equation, however, racial minorities existed outside the "qualified" pool. Minorities simply did not fit the "grand juror" profile. Forced inclusion of minorities, moreover, remained just that-forced and implicitly illegitimate. The push for minorities ran afoul of the judges' unexamined conception of who was qualified to serve as a grand juror. Just as the judges presumed the qualifications of those like themselves, they presumed the unsuitability of those unlike themselves. One could surmount this presumption, but only by affirmatively demonstrating the qualifications of the "atypical" nominee, a hurdle that the judges' friends decidedly did not face. Recall the conversation between Acosta and the judge who balked at answering whether minorities should sit on grand juries, instead stridently insisting on the dangers of empanelling unqualified persons. ${ }^{374}$ This judge simply could not conceive of minority representation on the grand jury except as a threat to quality; "qualified" for the Los Angeles superior court judges described them and their friends, not minorities. ${ }^{375}$

A bitter irony exists in the way racial institutions informed the selection and justificatory practices of the judges. Through racial institutions and institutionalized conduct, the judges' nominations of their White friends

374. See supra notes $368-370$ and accompanying text.

375. Consider in this regard Acosta's questioning of Judge John Frazer:

$Q$. Do you feel personally obligated as a Judge to seek out, affirmatively seck out persons from different racial groups as your nominees?

A. ... Actually, to me, what a person's race is is a minimal requirement. It doesn't make any difference to me whether they are Jewish, or black, or Spanish, or Mexican, or Oriental, or Caucasian, as far as I am concerned. If they are qualified. I would as soon appoint one as the other.

$Q$. Do you feel personally obligated to seek out, to affirmatively seek out persons from different racial groups as your nominees?

A. Well, if anyone is qualified, I will appoint-if I knew anyone who could scrve in any of those categories that you named, I certainly wouldn't hesitate to nominate them.

Q. What I'm trying to get at, Your Honor, is this: It appears that you don't know, or you know very few Spanish-sumamed persons, and so my question is, do you feel obligated to go out and look for other qualified Spanish-surnamed persons?

A. Not unless I-if I knew someone who was qualified, or it was indicated to me was well qualified, as I say, I wouldn't hesitate to contact them and ask them if they would serve.

Transcript, supra note 8, at 539-41. 
emerged as the race-neutral and legitimate seating of qualified grand jurors, while the cross-section requirement appeared to be an illegitimate demand for the inclusion of unqualified minorities. Put differently, for many judges it seems racial discrimination lay not in the almost exclusive nomination of White grand jurors, but in the demand for minority representation.

\section{E. Judicial Racism}

Racism involves complex combinations of intentions and actions. The typology of racism advanced earlier is not meant to suggest that individual acts of racism neatly disaggregate along exact lines. Rather, as the dynamics of discrimination in grand juror selection indicate, various forms of racism often combine. Nevertheless, typologizing racism clarifies institutionalism's lessons regarding that phenomenon.

Institutional analysis offers insight into the role of racial institutions not only in causing nonintentional discriminatory action, but also in supporting the plausibility of allegedly race-neutral rationalizations for such action. How did racism factor into the nomination practices on trial in East LA 13 ? Racism played out in the nomination practices themselves, as well as in the explanations offered to account for them-in short, racial institutions scripted racial status-enforcing discrimination, and paved the path of its justification and continuation.

\section{Script Racism}

Script racism parallels the notion of script institutionalism. It describes undirected racial status-enforcement undertaken in reliance on racial institutions. Script racism is influenced by racial institutions but impelled without any conscious thought. Reliance on scripts is a feature of organizational life. When racial institutions inform these accepted patterns, and when these patterns entrench racial hierarchy, following such scripts amounts to script racism.

Script racism describes the conduct of superior court judges across California in nominating friends and friends of friends as grand jurors. In general, prior to the East Los Angeles cases and the CRLA study, judges reflected little on how they selected grand jurors. Rather, virtually every California superior court judge selected nominees from among his or her social circle. Subscribing to this taken-for-granted procedure equaled script racism. First, the judges relied on the script without conscious thought. Second, the "pick your friends" script enforced racial hierarchy by favoring Whites and excluding Mexican Americans. Third, racial institutions suffused that script. It seems, then, that the judges largely testified honestly when they claimed they had no intent to discriminate in selecting grand jurors. Institutional analysis shows they had little conscious 
intent whatsoever, at least with respect to grand jury nomination systems. Nominating their friends-script racism-simply constituted part of the judges' daily routine.

\section{Path Racism}

Path racism parallels the notion of path institutionalism. Path racism encompasses directed racial status-enforcement that draws on racial institutions in an unrecognized manner. The crux of path as opposed to script racism lies in the former's motivated element, a significant difference that I soon address. For now, however, recognize that path racism occurs when racial institutions set the unrecognized boundaries for decision making-when racial institutions form the taken-for-granted path along which conscious choices occur. When racial institutions delimit decision making, and when action pursuant to such decision making enforces racial hierarchy, such action constitutes path racism.

Forced to confront the consequences of their practices, most judges consciously persisted in the "pick your friends" approach to grand jury nominations in the years after the East Los Angeles cases, the CRLA study, and so on. Path racism describes the action of those judges who opted to perpetuate the status quo for reasons informed by racial institutions, including the concern for securing "qualified" grand jurors. First, these judges acted in a directed manner. Second, their actions in nominating their acquaintances reinforced racial hierarchy. Third, racial institutions shaped their motivations in unrecognized ways.

Had one accused the judges who perpetuated the status quo of racism, they would have strenuously objected, insisting with the judges in East $L A$ 13 that they sought only to nominate qualified grand jurors. Yet their failure to develop effective criteria and screening protocols suggests a particular understanding of "best qualified." The contours of this understanding become evident when one considers that selecting qualified grand jurors translated into the continued selection of friends and neighbors. The judges accused of racism would genuinely protest that they did not intend to discriminate racially, for indeed most did not. Nevertheless, through path racism, racial institutions informed the motivations of most judges in an unrecognized manner that ensured the almost exclusive nomination of Whites.

\section{Purposeful Racism}

Some judges, of course, possessed a conscious intent to discriminate in favor of Whites or against Mexican Americans. To the extent that they entrenched racial hierarchy pursuant to such motivations, they engaged in 
purposeful racism. Purposeful racism involves directed racial statusenforcement motivated by an intention to discriminate harmfully. ${ }^{376}$

Like path racism, purposeful racism describes directed action that draws on racial institutions. Thus, the difference between purposeful and path racism does not lie in the motivated nature of the action, nor in whether such motivation draws on racial institutions. Rather, it lies in whether persons consciously adopt racial institutions for harmful purposes. Under path racism, actors fail to recognize the influence of racial institutions on their motivations, and have no intent to discriminate. With purposeful racism, actors consciously embrace racial institutions as a basis for intended racial status-enforcement. ${ }^{37}$

A distinction exists between those who enforce racial hierarchy for its own sake and those who engage in status-enforcement in the service of some secondary motive. In this latter category, one might place those who utilize race as a proxy for information, or who racially discriminate as a signaling device. ${ }^{378}$ For purposes of normative evaluation, this distinction seems important. ${ }^{379}$ Here, however, the central point remains that actors often purposefully embrace racial institutions when undertaking intentional racial status-enforcement. Under the definition proposed here, such actors engage in purposeful racism.

Direct evidence of purposeful racism among Califomia's superior court judges is sparse-Judge Chargin's outburst excepted, of course. Nevertheless, we should suspect that some judges, sharing some or all of

376. Some members of the Supreme Court doubt the possibility of distinguishing. either practically or morally, between those who consciously rely on mace and intend harmful discrimination and those who use race but do not intend to discriminate harmfully. According to members of the Court, the inevitability of harm whenever race is considered renders any distinction untenable. See, e.g., Adarand Constructors v. Peña, 515 U.S. 200, 241 (1995) (Thomas. J., concurring) (" [G]ovemment-sponsored racial discrimination based on benign prejudice is just as noxious as discrimination inspired by malicious prejudice. In each instance, it is racial discrimination, plain and simple." (footnote omitted)); see also id. at 24l n." ("[W] thether a law relying upon racial taxonomy is 'benign' or 'malign.' ... either turns on 'whose ox is gored.' or on distinctions found only in the eye of the beholder." (internal citations omitted)). I disagree strongly with the claim that reliance on race necessarily results in social harms. To the contrary. institutional analysis teaches that combating racism requires explicit invocations of racial ideas and language. See infra notes 400-406 and accompanying text.

377. Recall the earlier general definition of racism as "racial status-enforcement undertaken in reliance on racial institutions." See supra note 350 and accompanying text. The general definition is overinclusive on the purposeful-racism side to the extent that it labels as racism status-enforcing action by those who actively rely on racial institutions without harmful intent. I take this to be a small class of cases. But see the concems of Justice Thomas, supra note 376.

378. See supra notes 164-179 and accompanying text.

379. One might distinguish morally between what can be termed "malicious racism" - racial hierarchy enforcement for its own sake-and "indifferent racism"-harmful discrimination employed as a means to an end, where the resultant harm constiutes a matter of indifference or even mild regret to the actor. While an important distinction, both "malicious" and "indifferent" racism involve the conscious embrace of race as a basis for status-enforcement. In this sense, they are both "purposeful" racism and stand in contrast to the sorts of institutional, nonconscious racism on which this Article focuses. 
Judge Chargin's beliefs regarding Mexican Americans, intended to and did discriminate against that group. ${ }^{380}$

\section{F. Reconsidering Institutional Racism Theory}

\section{Script and Path Racism}

On one level, script and path racism blur together. Script racism, like scripted behavior generally, turns on the absence of conscious thought when certain routines are triggered-allowing someone to use a photocopier, or conforming to a certain means of nominating grand jurors. Within the dictates of such routines, however, actors may engage in substantial conscious action. Thus, one could describe much that I label here script discrimination as instead path racism. Likewise, because path racism countenances the unthinking reliance on racial institutions, one might be tempted to use the term script racism instead. For instance, one could plausibly characterize the judges' virtually uniform recourse to the language of qualifications as reliance on a script.

On another level, however, the script/path distinction contributes a critical insight: Path racism postulates that even when actors consciously evaluate their motivations, they often continue to rely on racial institutions in unrecognized ways. Building on this point, we can conceptualize script racism as occurring when persons enforce racial status hierarchy through an unrecognized reliance on racial institutions and without giving any thought to race, while path racism occurs when persons enforce racial hierarchy after carefully considering, and rejecting, the idea that race informs their actions. On this level, the distinction between script and path racism acquires great importance: While script analysis shows that the judges thoughtlessly discriminated in nominating grand jurors, path analysis demonstrates the remarkable continuation of such discrimination even after the majority of judges assured themselves that race did not figure in their intentions. In observing the daily effects of institutional racism, the distinction between script and path racism adds little. But in assessing the ability of institutional racism to continue even in the face of direct challenges to discriminators, the script/path distinction generates

380. Consider comments that Judge Chargin offered to the Los Angeles Times in the wake of the furor raised by his tirade from the bench: "I am pleased to say that my entire adult life, both in the law and on the superior court bench, has been an effort and a striving for justice for all. ... The most recent example of this is my nomination of the only Mexican-American individual presently serving on the County Grand Jury." SALAZAR, supra note 320 , at 226 . The East $L A 1.3$ transcript records many similar utterances by Los Angeles superior court judges, though usually absent the claim to have actually nominated any Mexican Americans. This does not suggest that the judges all lied. This Article argues just the opposite, that most genuinely believed themselves innocent of racism. Nevertheless, Los Angeles superior court judges' uniform insistence that they did not intend to discriminate does not preclude the possibility that some of them purposefully discriminated in selecting grand jurors. 
institutional racism theory's most important implication: Self-reflection and innocent intent do not forestall participation in path racism. Path racism may occur even with exacting self-examination and the purest of intentions.

\section{Institutional and Purposeful Racism}

The distinction between institutional and purposeful racism resides in the extent to which actors recognize race as influencing their motivations. Institutional analysis, which models human behavior in terms of the influence of unrecognized practices and understandings, seems well-suited to explain discriminatory action in the absence of such recognition. In particular, it affords a means of explaining how persons engage in actions with clear and even recognized discriminatory effects, and yet stridently insist and genuinely believe that they possess no discriminatory intent. Institutional racism analysis urges attention to scripts and paths indebted to institutionalized understandings of race.

Institutionalism's explanatory power is particularly pronounced in organizational settings, which frequently produce scripts and unexamined understandings. ${ }^{381}$ Organized life, however, does not provide an environmental boundary to institutional racism. All of social life depends on background routines and understandings, making institutional racism theory widely applicable. The racism evident in the actions and testimony of the judges in East LA 13 operated not just among the Los Angeles judges, or the superior courts, or the California criminal justice system, but also across law and society. Institutional analysis provides an essential tool for examining pervasive forms of racism.

The relative inability of other social science theories of behavior to model nonintentional racism enhances the importance of institutional analysis. Rational choice theory, in particular, fails here, not because it emphasizes rationality, but because it stresses conscious intent. Absent some theory of nonintentional action, rational choice theory cannot explain the discriminatory behavior of persons who genuinely do not intend to discriminate. Richard McAdams correctly perceived the need for the latter sort of theory, though his attempt to develop it foundered. Obligatory action theory similarly falters, for, while it places actors in a social context by stressing internalized values, it too looks to intent to explain action. Cognitive psychology helps far more than these other theories to explain nonintentional racism, and, indeed, it contributes valuably to an institutional analysis of racism. ${ }^{382}$ But psychology falls short of, and could benefit from, analysis that focuses on the group origins of taken-for-granted scripts and paths. Institutional theory best details the dynamics of path and script

381. See supra notes $276-294$ and accompanying text.

382. See supra note 357. 
racism, forms of racism both pervasive and otherwise difficult to model under alternative social science theories of behavior.

Nevertheless, despite its early rejection as the principal explanation for the actions of the superior court judges, intentional racism shadows the entire analysis. Institutional theory contributes to the modeling of script and path racism. Does institutional analysis add to accounts of purposeful racism? To a limited extent, yes.

First, institutionalism leaves room for purposeful racism's operation. Institutional racism theory incorporates the Judge Chargins of the worldor those who seek status, information proxies, or signaling mechanismsbecause such analysis does not rule out but rather specifically contemplates the possibility of directed action.

Second, institutionalism highlights the extent to which purposeful racism requires the acceptance of background notions of race. To engage in purposeful racism is usually not to shed but to embrace racial institutions. Those judges who believed in Mexican-American inferiority did not pierce but rather energetically adopted the institutionalized understandings surrounding that group; they discriminated against Mexican Americans not in spite of but because of racial institutions. This insight suggests that studies of intentional racism should attend to racism's cultural context. The historical setting, the evolution of cultural practices, a culture's memory of group origins, or its imagination of group futures-all of these belong in studies of purposeful racism. ${ }^{383}$

Third, an institutional approach suggests that institutional racism abets purposeful racism. To begin with, in settings where racism is institutionalized, certain forms of discriminatory action by definition appear legitimate and routine. Such contexts may encourage and even organizationally validate persons engaged in directed racial statusenforcement. In addition, purposeful racism becomes less obvious, and so less subject to social sanction, in settings of institutional racism. When institutional discrimination occurs, purposeful discrimination may not stand out. ${ }^{384}$ Finally, the superficially race-neutral rationales accepted under path racism may afford the intentional racist the ability to hide his or her pernicious motives behind the invocation of motivations widely accepted as

383. Cf. GoldBERG, supra note 185 , at 90 (noting that racism is always historically contingent).

384. Consider the recommendation of censure against Judge Chargin by the Califormia State Commission on Judicial Qualifications. Although the Commission described the judge's remarks as "improper and inexcusable," it opined that "there is no evidence of bias or prejudice by (the judge) except for the incident of Sept. 2, 1969." SALAZAR, supra note 320, at 251 (quoting the Commission). Assuming that racism motivated Judge Chargin to discriminate against Mexican Americans at other times, the Commission's inability to find evidence of such prejudiced action may reflect the difficulty of distinguishing Judge Chargin's purposefully racist conduct from the institutionally racist conduct of his colleagues. Of course, Judge Chargin may also have engaged in institutional racism. 
legitimate. In these various ways, institutional racism facilitates intentional racism.

All of that said, however, it remains the case that institutional analysis does not powerfully model intentional racism. Institutionalism's strength does not lie in explaining intentional action per se, nor does it have much to offer regarding the formation of intentions. ${ }^{385}$ Indeed, to the extent that purposeful racism is functional-geared toward the achievement of larger social interests-institutionalism's inability to contribute much regarding intentional racism emerges as its most potent failing. New Institutionalism is most sophisticated concerning, and most interested in, the operation of already established institutions. Questions that necessarily broaden the historical sweep of the inquiry-how institutions arise, persist, and collapse-have received less attention. ${ }^{386}$ "Power and interests have been slighted topics in institutional analysis." 387 This relatively focused quality contributes to institutionalism's efficacy when applied to narrowly circumscribed case studies, such as here. But it also limits the ability of institutionalism to account for the functional role of social phenomena, even in terms of the origins and disintegration of institutions. ${ }^{388}$ In the elaboration of the racial institutions it otherwise analyzes with acuity, an institutional model runs the risk of excluding, at the level of theoretical focus, attention to purposeful racism and the functional role of racial hierarchy. In this regard, institutionalism's strength and weakness reside in its narrow temporal focus and proclivity for divorcing institutions from the forces impelling their rise and collapse.

\section{CONCLUSION: INSTITUTIONAL RACISM'S DOCTRINAL AND NORMATIVE IMPLICATIONS}

Oscar Acosta and the defendants in the East Los Angeles cases accused the Los Angeles superior court judges of discriminating against Mexican Americans in nominating grand jurors. To make their case, the East LA 13 and Biltmore 6 activists relied on numbers-the judges' actual nominations

385. To be clear, it is no surprise that New Institutionalism says litule on this score, since explaining intentional action is not one of its objectives.

386. See DiMaggio \& Powell, supra note 12, at 27-28. There are, however, numerous and increasing exceptions. See, e.g., Søren Christensen \& Jan Molin, Origin and Transformation of Organizations: Institutional Analysis of the Danish Red Cross, in THE INSTITUTIONAL CONSTRUCTION OF ORGANIZATIONS, supra note 245. at 67; Friedland \& Alford, supra note 13. Political scientists lead the way in combining historical and institutional analysis. See, e.g., STRUCTURING POLITICS: HISTORICAL INSTITUTIONALISM IN COMPARATIVE ANALYSIS (Sven Steinmo et al. eds., 1992); Rogers M. Smith, Political Jurisprudence, the "New Institutionalism," and the Future of Public Law, 82 AM. POL. SCI. REV. 89 (1988).

387. DiMaggio \& Powell, supra note 12 , at 30.

388. Mary Douglas provides a helpful discussion of what a functional theory of unintentional action might look like. See DOUGLAS, supra note 1, at 31-43; see also Friedland \& Alford, supra note 13; Ronald L. Jepperson \& John W. Meyer, The Public Order and the Construction of Formal Organizations, in THE NEW INSTTUTIONALISM IN ORGANIZATIONAL ANALYSIS, supra note 12, at 204. 
reduced to small data points that in composite produced a vivid portrait of that community's almost total exclusion. In the decade leading up to those cases, Mexican Americans accounted for no more than $1.7 \%$ of Los Angeles's grand jurors, despite the fact that the Mexican-American community constituted roughly fourteen percent of the County's population. ${ }^{389}$ But the activists did not rely on numbers alone. In addition, they sought to make their case by calling superior court judges to testify. Once on the stand, however, the judges did more than describe their nominees; they also denied, in the strongest terms, that they ever intended to discriminate against Mexican Americans. The trial courts accepted their fellow judges' denials and rejected the activists' equal protection challenge for lack of evidence of purposeful racism. ${ }^{390}$ Acosta and the defendants, the courts concluded, wrongly alleged judicial discrimination against Mexican Americans.

Thirty years later, little has changed in the selection of grand jurors in Los Angeles County. In the decade leading up to 1969, Mexican Americans suffered exclusion from Los Angeles County grand juries at a ratio of eight to one; in the 1990s, a six-to-one segregation rate governed all Latino/as. ${ }^{391}$ In the 1960s, the Los Angeles superior court judges nominated all grand jurors; in the 1990s, they did the same. ${ }^{392}$ At the close of the sixties, each and every superior court judge who testified in East LA 13 insisted that he had no intention to discriminate. ${ }^{393}$ Contemporary superior court judges, each and every one, almost certainly would reaffirm that denial.

Stokely Carmichael and Charles Hamilton introduced the phrase "institutional racism" in 1967 to explain harms inflicted on minorities other than through individual racist actions. ${ }^{394}$ Acosta may have learned this term before or while representing the activists in East LA 13 and Biltmore $6 .{ }^{395}$ Regardless of whether he knew the phrase itself, he subscribed to the idea behind it. Acosta claimed neither that the judges excluded Mexican Americans intentionally nor that the underrepresentation of Mexican Americans alone created a constitutional violation. Rather, Acosta urged the court to recognize that a "system" within which Mexican Americans "don't exist" produced their exclusion. ${ }^{396}$ How this "system" operated, however, neither Acosta, nor Carmichael and Hamilton, nor the many others who since have used the phrase "institutional racism," ever fully explained. Reconciling the discrimination in the Los Angeles cases and in

389. See supra note 81 and accompanying text.

390. See supra notes $158-159$ and accompanying text.

391. See supra note 151 and accompanying text.

392. See supra notes 46 and 147 and accompanying text.

393. See supra notes $152-153$ and accompanying text.

394. See CARMICHAEL \& HAMLTON, supra note 28 , at 4-5.

395. Certainly, the Black Power movement influenced the growing militancy in East Los Angeles by the end of 1967 and the beginning of 1968 , months before the high-school walkouts. See Mữoz, supra note 2, at 59.

396. See supra note 157 and accompanying text. 
the contemporary exclusion of Latino/as with the elaborate denials of discriminatory intent registered thirty years ago and likely today requires a fuller account of institutional racism.

Relying on the cognitive and cultural insights of institutional analysis, this Article advances a new conception of the racism evident both in the Los Angeles cases and much more widely. Appropriating the term "institutional racism," this Article describes how individual actors often unintentionally engage in racial discrimination by relying on unexamined background understandings. These background understandings, or institutions, develop through group interactions, and thus accrete at various rates depending on the social context. The more organized and formal the setting, the more likely that such grammars develop and dictate behavior. Within organized contexts, reliance on institutions often proceeds almost automatically in the sense that persons do not reflect on their actions but instead seem to follow a script. At other times, actors consciously reflect even as they remain channeled into thinking along certain lines, as if pursuing a path that requires rational thought but that nevertheless largely delimits imaginable options. Institutional racism theory stresses how racial institutions, whether followed in a script or path form, operate as taken-forgranted understandings of the social context that actors must adopt to make sense of the world, as well as to be accepted as bona fide members of that milieu. Under the sway of institutional racism, persons fail to recognize their reliance on racial notions, and indeed may stridently insist that no such reliance exists, even while acting in a manner that furthers racial status hierarchy.

The institutional racism theory advanced here helps us to understand the "system" to which Acosta drew attention in the East Los Angeles cases. But it also has lessons for contemporary social practices, judicial and otherwise. This Article concludes by turning to some of the doctrinal and normative implications of institutional racism. Before that, however, consider what institutional racism theory suggests about racism's ubiquity and intractability.

\section{A. The Ubiquity and Intractability of Institutional Racism}

Institutional racism theory implies racism's ubiquity. The definition of racism offered above perhaps suggests a relatively sharp boundary between what is and is not racism. This boundary is at best indistinct, however, because institutional racism pervades our society. This Article defines racism as racial status-enforcement coupled with a reliance on racial institutions. But recall that racial institutions form part of the world-knownin-common by members of our society, and that we are all constituted by 
and cognitively rely on racial institutions. ${ }^{397}$ To this extent, reliance on racial institutions becomes normal, and escape from such reliance, the rare exception. In such circumstances, the touchstone for differentiating racism from nonracism largely reduces to racial status-enforcement itself. In all cases of racial status-enforcement, institutional analysis suggests that reliance on racial institutions likely exists, whether direct or attenuated.

Consider government decisions that affect poor persons generally. These decisions may seem racially neutral, despite their more pronounced harm to minorities engendered through the disproportionate presence of nonwhites among our society's poor. Such decisions, if truly independent of racial institutions, might not be considered racism at all. ${ }^{398}$ Nevertheless, recent scholarship demonstrates that few such governmental actions are race-neutral; rather, reliance on racial institutions often taints them. The long history of racism in the shaping of welfare policies, for instance, evidences not only purposeful but also institutional racism. ${ }^{399}$ Racial statusenforcement in the absence of influence from racial institutions surely exists, but institutional racism produces much that we usually consider an accident of inequality. Instances of harmful discriminatory action taken without reliance on racial institutions ultimately may be quite few. Thus, racism is nearly as ubiquitous as racial status-enforcement.

Institutional analysis also suggests racism's intractability. Individual reliance on racial scripts or paths pervades our society. Yet background patterns and understandings are difficult to deinstitutionalize, particularly in organized settings. ${ }^{400}$ Linda Krieger details the conditions that must obtain before well-intentioned individuals can control cognitive biases in their

397. See supra notes 346-349 and accompanying text.

398. Nevertheless, some scholars define discriminatory action produced in the absence of any particular motivation or behavior as "institutional racism." See FEAGIN \& FEAGIN, supra note 18. at 31-33. If one thought it appropriate to label such action racism, one could apply the tcrm "structural racism." $C f$. IRIS MARION YOUNG, JUSTICE AND THE POLITICS OF DIFFERENCE 40 (1990) (describing "structural oppressions").

399. See generally LINDA GORDON, PITIED BUT NOT ENTITLED: SINGLE MOTHERS AND THE HISTORY OF WELFARE 1890-1935, at 84-88, 114-23 (1994); JILL QUADAGNO. THE COLOR OF WELFARE: HOW RACISM UNDERMINED THE WAR ON POVERTY (1994); Dorothy E. Roberts, Welfare and the Problem of Black Citizenship, 105 YALE L.J. 1563, 1569-72 (1996) (reviewing GORDON, supra; QUADAGNO, supra).

400. Here again Zucker's work is instructive. In a companion experiment to the one discussed above, see supra notes 277-295 and accompanying text, Zucker also measured what she termed "resistance-to-change." Zucker, supra note 21 , at 99-101. She found that in the "personal" condition subjects willingly changed their estimations under the influence of a confederate playing the role of the second viewer, while subjects in the "organization" and "office" condition were progressively less likely to change their estimates. See id. at 100 . Zucker concluded,

The results of my... experiment were surprising in the ease with which institutional effects were created: an instructional manipulation of a seemingly trivial action embued the system with meaning. As the results of my [subsequent] experiment indicated, such effects were much more difficult to destroy. Institutionalization often occurs accidentally, as a by-product of the creation of other structures: deinstitutionalization is seldom accidental. Once institutionalized, structure or activity Id. at 105 . may be maintained without further action . . . . 
own actions. According to Krieger, they must (1) become aware of the effects of such biases; (2) be motivated to overcome such effects; (3) correctly discern the direction and magnitude of error, to avoid overcorrection; and (4) possess sufficient control over mental processes to allow correction. ${ }^{401}$ Where cognitive biases arise through reliance on institutions shared by groups, rather than through the operation of standard heuristics that individuals may learn to be wary of, the likelihood that individuals can tame such biases may be further reduced.

Altering institutions, rather than individual actions, introduces yet further challenges. As Larry Lessig points out, reworking institutions (in his language, "social meanings") involves collective-action problems. ${ }^{402}$ Because institutions gain meaning among social groups, remaking institutions requires altering collective understandings. However, individuals often face incentive structures that make it less costly to abide by norms they disagree with than to act to change them. ${ }^{403}$ Finally, to the extent that social action turns on individual assessments of incentive structures, such assessments will themselves vary as a function of received grammars. ${ }^{404}$ People are embedded in, and therefore not strategically dispassionate about, the institutions they seek to change. To be sure, individuals and communities can purposefully alter racial institutions-but not in any neat, easy, or predictable way. ${ }^{\text {tos }}$ Unlike many social science theories of discrimination, an institutional approach suggests that racial discrimination is highly intractable. ${ }^{406}$

Institutional racism analysis strongly implies that racism in our society is both endemic and relatively ineradicable. It follows that in the face of discrimination, to ask only whether racism is present betrays an incomplete understanding of that phenomenon. Where racial status-enforcement looms,

401. See Krieger, supra note 344, at 1286. Krieger is skeptical about the ability of individual actors to counteract cognitive biases successfully. See id. at 1286-91.

402. Lessig, Regulation of Social Meaning, supra note 240, at 993. Lessig writes, "Social meanings are constituted by contexts of understanding; they are reconstructed when contexts of understanding change; but contexis change when collections of individuals change, and hence the problem of social meaning making is how to get these groups to change." Id.

403. See id, at 1001 .

404. On this level, speculation about "meaning manager[s]," id. at 1008 - or for that matter "norm entrepreneurs," Sunstein, supra note 240 , at 909-who strategically manipulate institutions, seems to ignore the extent to which such managers or entrepreneurs are themselves constituted by the institutions they purportedly wield. See Doug McAdam et al.. To Map Contentious Politics, 1 MoBILIZATION 17, 25-26 (1996) ("The image one emerges with is of an isolated outsider deciding whether or not to affiliate with a given instance of collective action 'offered' by an entrepreneur of some sort. What this view misses is the degree to which individuals are already embedded and ontologically invested in various kinds of social structures and practices."); see also David A. Snow et al., Frame Alignment Processes, Micromobilization, and Movement Participation, 51 AM. SOC. REv. 464, 470 (1986).

405. Indeed, it is possible to understand the activism in the Mexican-American community that eventually led to East LA 13 and Biltmore 6, as well as the Black Power and other racial minority movements of the late 1960s and early 1970s, as efforts to alter the institutionalized understandings and practices regarding those groups.

406. Many social science theories of racism treat the phenomenon as largely irrational and therefore relatively easily remedied. See FEAGIN \& FEAGIN, supra note 18 , at 5. 
the most important question is not whether racism exists, but in what form, to what degree, and with what impact. What are the nature and extent of the cognitive reliance on racial institutions? If purposeful, what sorts of racial institutions are embraced? If nonconscious, how strictly do racial institutions channel action? Alternatively, what of the discriminatory impact: Is it severe and direct, or attenuated and ambiguous? Does it impinge on a few, or harm an entire group? These are the questions one must ask about racial status-enforcement and racism.

\section{B. Institutional Racism and Equal Protection}

When the East LA 13 and Biltmore 6 defendants raised their equal protection challenges, the U.S. Supreme Court had long been oscillating between two tests to establish such a violation. One test looked to exclusionary patterns. For instance, observing the complete absence of Mexican Americans from grand or petit juries in a Texas county over at least a quarter-century, the Court ruled that "[t]he result bespeaks discrimination, whether or not it was a conscious decision on the part of any individual jury commissioner." 407 The other test, however, focused on purposeful racism. Thus, in other cases the Court wrote that "[t]he statements of the jury commissioners that they chose only whom they knew ... prove the intentional exclusion that is discrimination in violation of ... constitutional rights," ${ }^{408}$ and also that "an imperfect system is not equivalent to purposeful discrimination based on race." 409 Castañeda $v$. Partida ended this oscillation in 1977, declaring that the Court's prior cases effectively "established the principle that substantial underrepresentation of the group constitutes a constitutional violation... if it results from purposeful discrimination." ${ }^{410}$ Citing Washington v. Davis, ${ }^{411}$ Castañeda added that " $[r]$ ecent cases have established the fact that an official act is not unconstitutional solely because it has a racially disproportionate impact." 412 Recall that in both East LA 13 and Biltmore 6, the presiding judges rejected

407. Hernandez v. Texas, 347 U.S. 475, 482 (1954). Hernandez echoed the Court's ruling in Smith v. Texas, 311 U.S. 128 (1940), that "[i]f there has been discrimination, whether accomplished ingeniously or ingenuously, the conviction cannot stand." Id. at 132; see also Recce v. Georgia, 350 U.S. 85, 88 (1955) (finding "discrimination 'ingenious or ingenuous," and citing Smith).

408. Cassell v. Texas, 339 U.S. 282, 290 (1950) (plurality opinion).

409. Swain v. Alabama, 380 U.S. 202, 209 (1965). This holding tracked the Court's earlicr decision in Akins v. Texas, 325 U.S. 398 (1945), that "[a] purpose to discriminate must be present which may be proven by systematic exclusion of eligible jurymen of the proscribed race or by unequal application of the law to such an extent as to show intentional discrimination." Id. at 40304.

410. 430 U.S. 482.493 (1977).

411. 426 U.S. 229 (1976).

412. Castañeda, 430 U.S. at 493. Of course, to some extent the Court only displaced this oscillation to the question of how parties prove intentional animus. See infra note 415 . 
the activists' equal protection challenges because they failed to prove intentional discrimination. ${ }^{43}$

The East Los Angeles cases demonstrate that discrimination against Mexican Americans did not result solely from purposeful conduct, but rather from some combination of purposeful and institutional racism. It seems likely that varying blends of purposeful and institutional racism also underlie virtually every jury discrimination case-and, quite probably, every equal protection claim-to have come before the courts. This observation alone does not establish that the Supreme Court erred in installing purposeful racism as the sole constitutional concern regarding racial discrimination. The question of what racism the law should address, and what it should permit and by implication sanction, requires not just an understanding of racism, but also a vision of law's role in the achievement of social justice. ${ }^{414}$ Nevertheless, institutional racism analysis carries doctrinal implications, not least with regard to equal protection

413. See supra notes $158-159$ and accompanying text. The requirement that one prove "a racially discriminatory purpose" has been extended to cases involving discrimination in the selection of trial juries. See Batson v. Kentucky. 476 U.S. 79. 93 (1986). Batson marked an advance in the battle against racial discrimination insofar as it allowed defendants to question the use of preemptory challenges to exclude minorities from particular jury panels. Sec id. al 96. Justice Marshall, in a concurring opinion, nevertheless criticized the majority's decision to allow preemptory challenges at all, reasoning that requiring defendants to show purposeful racism, and allowing prosecutors to rebut such claims through the assertion of race-neutral reasons, effectively rendered Batson's reforms "illusory." Id. at 106 (Marshall, J., concuring). Justice Marshall wrote that " [a]ny prosecutor can easily asser facially neutral reasons for striking a juror, and trial courts are ill equipped to second-guess those reasons." Id. In reasoning akin to that advanced by Charles Lawrence, he also suggested the following:

A prosecutor's own conscious or unconscious racism may lead him easily to the conclusion that a prospective black juror is "sullen," or "distant," a characterization that would not have come to his mind if a white juror had acted identically. A judge's own conscious or unconscious racism may lead him to accept such an explanation as well supported .... Even if all parties approach the Coun's mandate with the best of conscious intentions, that mandate requires them to confront and overcome their own racism on all levels-a challenge I doubt all of them can meet.

Id. Justice Marshall's concem regarding the inability of court officers to "overcome their own racism on all levels" applies to institutional racism as well.

414. Institutional theory demonstrates that actors rely on institutionalized understandings of all social identities, thereby suggesting that one must look to a general theory of social justice. not specifically to a theory of racial justice. Nevertheless, with respect to race and the Fourteenth Amendment, there are a number of contending visions, most related to onc of thre main choices developed over the last quarter-century: a process-defect approach. closely associated with John Ely; the antidiscrimination principle advocated by, among others. Paul Brest; and the antisubordination approach worked out, in par, by Owen Fiss and Kenneth Karst. See. e.g.. Jows HART ELY, DEMOCRACY AND DISTRUST 14-21 (1980); Paul Brest, The Supreme Court, 1975 Term-Foreword: In Defense of the Antidiscrimination Principle, 90 HARv. L. REV. 1. 5 (1976): Owen M. Fiss, Groups and the Equal Protection Clause. 5 PHIL. \& PUB. AFF. 107. 157.70 (1976); Kenneth L. Karst, The Supreme Court, 1976 Term-Foreword: Equal Cirizenship Under the Fourteenth Amendment, 91 HARV. L. REV. 1. 4-5 (1977). Recent contenders include colorblindness as well as antistatus and anticaste approaches. See, e.g., Adarand Constructors v. Peña, 515 U.S. 200, 239-41 (1995) (Scalia, J., concurring, and Thomas, J., concurring) (advocating coloblindness); Balkin, supra note 186, at 2315 (presenting a status-based approach); Cass R. Sunstein, Affirmative Action, Caste, and Cultural Comparisons, 97 MiCH. L. REV. 1311, 1311 (1999) [hereinafter Sunstein, Affimative Action] (supporting the anticaste principle): Cass R. Sunstein, The Anticaste Principle, 92 MICH. L. REV. 2410 (1994) (hereinafter Sunstein, Anticaste] (setting forth the anticaste principle). 
jurisprudence. Institutional racism theory offers a critique of the reasoning behind the purposeful racism limit to equal protection, especially as it has recently evolved, and also highlights the social costs of this constricted approach.

\section{Limiting Equal Protection}

Washington $v$. Davis established the rule that, regarding facially raceneutral government action, equal protection applies almost exclusively to cases of purposeful racism. ${ }^{415}$ To that extent, it probably ranks as the most important equal protection case of the last quarter-century. While justifications abound for limiting equal protection to cases of intentional discrimination, the reasoning in Davis provides perhaps the most widely accepted rationale. The Court there offered the following principal objection to extending equal protection to situations of disproportionate harm:

A rule that a statute designed to serve neutral ends is nevertheless invalid, absent compelling justification, if in practice it benefits or burdens one race more than another would be far reaching and would raise serious questions about, and perhaps invalidate, a whole range of tax, welfare, public service, regulatory, and licensing statutes that may be more burdensome to the poor and to the average black than to the more affluent white. ${ }^{416}$

Many commentators have focused on Davis's "parade of horribles," the supposed dire consequences for the efficient administration of the state

415. The Court has not been blind to the limits of a rigid search for "purposeful racism." Indeed, the Court has long accepted evidence of egregiously disproportionate impact as itself indicative of intentional discrimination. See Yick Wo v. Hopkins, 118 U.S. 356, 374 (1886). Davis recognized this exception. See Davis, 426 U.S. at 241-42. This approach is evident in the equal protection jurisprudence surrounding jury discrimination. In this area, the Court presumes intentional discrimination to exist once a showing of sufficiently disproportionate impact has been made, placing the burden on state officials to disprove intentional animus rather than on the challengers to prove its existence. See Castañeda, 430 U.S. at 494-95. Importantly, the Court has refused to accept the testimony of state officials, even judges, merely denying discriminatory intent, as sufficient to overcome the presumption of purposeful exclusion. See Eubanks v. Louisiana, 356 U.S. 584, 587 (1958). Rejecting the adequacy of such testimony, the Court wrote,

True, the judges now serving on the local court testified generally that they had not discriminated against Negroes in choosing grand juries, and had only tried to pick the best available jurors. ... [However, we] are reluctantly forced to the conclusion that the uniform and long-continued exclusion of Negroes from grand juries shown by the record cannot be attributed to chance [or] accident.... It seems clear to us that Negroes have been consistently barred from jury service because of their race.

Id. at 587-88. Despite an insistence on proof of intentional discrimination, the Court has occasionally shown itself willing to strike down certain practices in the absence of direct evidence, in the belief that some disparities are so great as to alone prove discriminatory intent. The development of this doctrinal exception demonstrates both the Court's lingering dissatisfaction with the implications of a strict purposeful-racism approach and the incoherence of that approach as applied.

416. Davis, 426 U.S. at 248. 
that a disproportionate-impact approach might produce. ${ }^{417}$ Before returning to that issue, however, note first and foremost Davis's invocation of statutes "designed to serve neutral ends." 418 The Court means "neutral" in the sense that no discriminatory animus underlies such statutes. However, institutional analysis cautions against too readily presuming the neutrality of statutes that "may be more burdensome to the poor and to the average black than to the more affluent white." 419 In practice, it seems likely to turn out that few such statutes in fact have been untainted by the influence of racial institutions. In that sense, institutional racism theory suggests that few government actions that impose disproportionate harms on minority communities are in fact race neutral.

Consider Davis itself. There, the Washington, D.C., police force sought to raise its "standards" and "achieve excellence," to quote the district court, by introducing the requirement that prospective police officers exceed a certain score on a standardized test. ${ }^{420}$ Yet, the established cutoff excluded four times as many African Americans as Whites. ${ }^{\text {t21 }}$ Instigated in the immediate context of pressures to desegregate a previously White force, an intention to discriminate-perhaps animated both by the desire to maintain a privileged position and by animus towards Blacks-most likely informed the decision to impose the new screening device. Whether purposeful racism played a role, however, institutional racism almost certainly did.

The hiring practices introduced by the police seem to reflect the same racialized concern for qualifications one sees in the California grand juror selection practices of the same era. Institutionalized notions of racial competence most likely informed both the adoption of the test and the decision to retain it despite the grossly disproportionate racial impact. Consider that, like the superior court judges, the police force adopted a procedure without calibrating its actual ability to measure appropriate qualifications. ${ }^{422}$ Just as the superior court judges in California insisted on "qualifications" as their principal concern but did not formulate practices to rationally assess them, the Washington, D.C., police force asserted an interest in raising its standards but did not validate the selected means against the actual duties of police officers. ${ }^{423}$ As in the grand jury context,

417. See, e.g., Karst, supra note 414 , at 50 (observing that "[t]he specter of the stopping place problem, it would seem, is no more "easily cabined" than the idea of Equality" (footnote omitted)).

418. Davis, 426 U.S. at 248 (emphasis added).

419. Id.

420. Id. at 236.

421. See id. at 237.

422. Indeed, one issue in Davis was whether the Equal Protection Clause required the police to validate the efficacy of their hiring standard, as Title VII would have-for example, "by ascertaining the minimum skill, ability, or potential necessary for the position at issue and determining whether the qualifying tests are appropriate for the selection of qualified applicants for the job in question." Id. at 247. The Courn held it did not. See id. at 247-48.

423. See id. at 235-36. 
one must hesitate to credit as untainted by racial institutions an invocation of qualifications when the means selected were not in fact formulated to that end, but seemed instead simply to promote the overrepresentation of Whites.

Note further that the institutional racism evident in the police force's unexamined refrain of standards extends to the Davis opinion itself. The Court asserts that "it is untenable that the Constitution prevents the Government from seeking modestly to upgrade the ... abilities of its employees rather than to be satisfied with some lower level of competence." ${ }^{424}$ However, the Court could come to this position only by accepting at face value the very claim at issue: that the sole impetus behind this test was the claimed intention to "modestly upgrade" employees. In accepting this claim, the Court's majority failed to recognize that "qualifications"-for the Washington, D.C., police force, the California superior court judges, and apparently even for itself-served in substantial part as a taken-for-granted understanding of the desirability of Whites over nonwhites.

Institutional racism analysis demonstrates that Davis misunderstands the nature of racism, at least insofar as the decision implies that statutes or other government actions that do not evidence purposeful racism are consequently race-neutral. Davis directs the courts to guard against conscious animus, but in doing so it turns equal protection away from the institutional practices that also produce racially discriminatory harms. Such institutional racism may well permeate society; certainly, the East Los Angeles cases and even Davis suggest that it substantially afflicts the courts themselves.

\section{Racism in Recent Supreme Court Equal Protection Cases}

Despite its limited conception of racism, in comparison to recent evolutions in equal protection, the holding in Davis seems defensible and restrained-defensible, because Davis's equation of racism with purposeful racism insured that the Equal Protection Clause would at least address a major source of racial harm, ${ }^{425}$ and restrained, because Davis did not arrogate to the Court the sole authority to identify racism, but instead specifically left room for other branches of government to define the sorts of invidious practices that required state intervention. ${ }^{426}$ Recent Supreme Court equal protection decisions have not been so enlightened.

424. Id. at $245-46$.

425. Of course, by the time the Court handed down Washington v. Davis in 1976, purposeful racism of the sort the Court focused on was already waning as a source of social harm. not only relative to its influence in earlier decades, but relative also to other forms of racism.

426. Compare Davis to other cases of that era in which the Court upheld the ability of Congress and administrative agencies to address disparate impact discrimination. In Griggs $v$. Duke Power Co., 401 U.S. 424 (1971), for instance, the Court ruled that Title VII of the 1964 


\section{a. Redefining Racism}

In confronting disproportionate harms imposed on minority communities, Davis reasoned as if the absence of purposeful racial animus demonstrates that race plays no role in producing such disproportionate outcomes, at least for constitutional purposes. This sort of reasoning continues to hold sway. For example, in McCleskey v. Kemp, the Court upheld Georgia's imposition of the death penalty because the Court found no purposeful racism, despite accepting the findings of a massive sentencing study showing that race-of the defendant and of the victimfigured prominently in who lived and who died at the hands of the Georgia criminal justice system. ${ }^{427}$ However, if such reasoning predominated into the 1980s, in the last decade the Court seems to have subtly but crucially altered its understanding of racism. In recent equal protection cases, the Court has moved from a search for purposeful racism to an inquiry into whether decision makers consciously considered race. The Court increasingly articulates an equal protection jurisprudence in which any explicit consideration of race, but only such consideration, amounts to purposeful racial discrimination.

Facially race-based statutes evidence the first par of this new development. In affirmative action cases involving government set-asides, such as City of Richmond v. Croson ${ }^{428}$ and Adarand Constructors v. Peña, ${ }^{429}$

Civil Rights Act "proscribes not only over discrimination but also practices that are fair in form. but discriminatory in operation. .. Congress directed the thrust of the Act to the consequences of employment practices, not simply the motivation." Id. at 431-32. Similarly, in Lau v. Nichols, 414 U.S. 563 (1974), the Court ruled that under Title VI of the 1964 Civil Rights Act, prohibiting discrimination in any program or activity receiving federal funding, the Deparment of Health. Education, and Welfare has the power to provide that "[d]iscrimination is barred [on the basis of effect even though no purposeful design is present." ld. at 568. Davis embraced a "purposeful racism" understanding only concerning the Constitution, and left to other branches of govemment the power to adopt broader understandings of racism. Note in this respect that Davis includes the following statement: " $\left.\prod\right]$ n our view, extension of the [disparate impact] rulc beyond those areas where it is already applicable by reason of statute, such as in the ficld of public employment. should await legislative prescription." Davis, 426 U.S. at 248.

427. 481 U.S. 279, 320 (1987) (Brennan, J., dissenting). "At most," Justice Powell wrote for the majority, the study "indicates a discrepancy that appears to correlate with race ... [but] we decline to assume that what is unexplained is invidious." Id. at 312-13. Justice Brennan, in dissent, summarized the findings of the sentencing study as follows:

[B]lacks who kill whites are sentenced to death at nearly 22 rimes the rate of blacks who kill blacks, and more than 7 rimes the rate of whites who kill blacks. In addition, prosecutors seek the death penalty for $70 \%$ of black defendants with white victims, but for only $15 \%$ of black defendants with black victims, and only $19 \%$ of white defendants with black victims. Since our [1976] decision upholding the Georgia capital sentencing system ... the State has executed seven persons. All of the seven were convicted of killing whites, and six of the seven executed were black. Such execution figures are especially striking in light of the fact that. during the period encompassed by the Baldus study, only $9.2 \%$ of Georgia homicides involved black defendants and white victims, while $60.7 \%$ involved black victims.

Id. at 327 (Brennan, J., dissenting) (citations omitted).

428. 488 U.S. 469 (1989).

429. 515 U.S. 200 (1995). 
the Court has concluded that any mention of race requires strict scrutiny. But the Court's new fascination with explicit considerations of race also extends to laws "neutral" on their face. ${ }^{430}$ Consider Shaw v. Reno. ${ }^{431}$ In Shaw, the Court used the Equal Protection Clause to strike down North Carolina's enactment of a majority-Black electoral district, a district fashioned pursuant to the Voting Rights Act of 1965 that produced the first African-American member of Congress from that state since Reconstruction. ${ }^{432}$ The Court previously had ruled that challenges to electoral districting required a showing of purposeful discrimination and discriminatory effect. ${ }^{433}$ In Shaw, however, the Court accepted a challenge that alleged instead a "right" to "participate in a 'color-blind' electoral process." ${ }^{434}$ Recognizing this right, the Court struck down North Carolina's plan because, in its shape, the district "rationally can be viewed only as an effort to segregate the races." ${ }^{435}$ In effect, the Court rescinded North Carolina's new district because race served as a predominant factor in the redrawing of district boundaries-yet, redistricting under the Voting Rights Act necessarily involved addressing racial voting imbalances. ${ }^{436}$ Shaw and other cases demonstrate that the Supreme Court increasingly views the open consideration of race as doctrinally akin to purposeful racism (irrespective of whether such consideration is necessary to remedy discrimination), thereby requiring heightened—and effectively fatal-scrutiny. ${ }^{437}$

The Court now largely finds racism wherever decision makers explicitly take account of race. But it is also increasingly true that the Court spies racism only where state actors consciously consider race. Consider Justice O'Connor's concurrence in a recent jury discrimination case, Hernandez v. New York. ${ }^{438}$ Hernandez rejected an equal protection challenge to the actions of a prosecutor who struck every Latino/a member of a petit jury on the ground that as Spanish speakers, they could not fully accept an interpreter's English translation when witnesses testified in

430. See Miller v. Johnson, 515 U.S. 900, 905 (1995).

431. 509 U.S. 630 (1993).

432. See id. at 659 (White, J., dissenting).

433. See City of Mobile v. Bolden, 446 U.S. 55 (1980).

434. Shaw, 509 U.S. at 641-42.

435. Id. at 642 .

436. Miller $v$. Johnson construes Shaw as holding that race may factor in redistricting, but it may not predominate. See 515 U.S. 900,913 (1995).

437. Shaw attempts a Bakke-like balancing. See Regents of the Univ. of Cal. v. Bakke, 438 U.S. 265, 318 (Powell, J.) (holding that race may be considered as one among a number of factors in higher-education admissions decisions). It seems likely, however, that the Court-as it does in Miller-will strike this balance in a manner that increasingly limits the extent to which race may be considered in redistricting decisions. In this context, Justice O'Connor's insistence that strict scrutiny is not "strict in theory but fatal in fact" rings hollow. See Adarand Constructors v. Peña, 515 U.S. 200, 202, 237 (1995); LAURENCE H. TRIBE, AMERICAN CONSTITUTIONAL LAW 1451-52 (2d ed. 1988).

438. 500 U.S. 352 (1991). 
Spanish. ${ }^{439}$ Concurring in the rejection of this claim, Justice O'Connor commented,

[The strikes] may have acted like strikes based on race, but they were not based on race. No matter how closely tied or significantly correlated to race the explanation for a peremptory strike may be, the strike does not implicate the Equal Protection Clause unless it is based on race. ${ }^{40}$

Under Justice O'Connor's reasoning, "no matter how closely tied or significantly correlated to race" ${ }^{441}$ an action otherwise might be, purposeful racism does not exist unless a government agent explicitly invokes race. ${ }^{42}$

In emphasizing the conscious consideration of race, the Court deviates from Davis by rendering purposeful racism increasingly irrelevant to constitutional analysis. Under O'Connor's reasoning in Hernandez, purposeful racism cannot be shown unless the state actor openly considers race. The consideration of race, however, already triggers heightened review under cases like Shaw, Croson, and Adarand; thus, a showing of purposeful racism becomes redundant. Absent the open consideration of race, neither racism nor cause for heightened review exists; yet, where race is facially considered, strict scrutiny applies irrespective of any showing of purposeful racism. The Supreme Court seems to be transmuting the search for racism into a simplistic inquiry into the existence of explicit considerations of race. Reference to race emerges, under current doctrine, as the measure of racism.

One does not need institutional analysis to see error in such a doctrinal approach. Indeed, Justice Stevens in his dissent in Adarand powerfully objects to this development in plain and direct language, decrying the resultant equation of race-conscious remedies with the worst excesses of racism. ${ }^{443}$ Institutional racism theory, however, advances our understanding

439. See id. at 372. The Hemandez Court seemed untroubled by the fact that the prosecutor questioned only the Latino/a venire members and no others about their Spanish ability. The opinions, whether majority or concurrence, failed to address this issue. though it figured prominently in the record below. See Sheri Lynn Johnson, The Language and Culture (Nor To Say Race) of Peremptory Challenges, 35 WM. \& MARY L. REV. 21. 53 (1993).

440. Hernandez, 500 U.S. at 375. Justice $O^{\prime}$ Connor in nearly the same breath referenced Davis and wamed of "the dangers of a rule that would allow an equal protection violation on a finding of mere disproportionate effect." Id. at 374.

441. Id. at 375.

442. Perhaps Justice O'Connor meant to make the doctrinal nather than evidentiary point that disproportionate effect alone is insufficient to establish the purposeful discrimination required under Batson. See supra note 413. Given her language, however, it seems unlikely that Justice O'Connor would accept as evidence of purposeful racism anything shor of an admission to that effect-or open references to race. In effect, then, Justice $O^{\prime}$ Connor's doctrinal concems become evidentiary ones.

443. Justice Stevens wrote:

There is no moral or constitutional equivalence between a policy that is designed to perpetuate a caste system and one that seeks to eradicate racial subordination. Invidious discrimination is an engine of oppression, subjugating a disfavored group to enhance or maintain the power of the majority. Remedial race-based preferences reflect 
of why "purposeful racism" and now the explicit consideration of race fail as proxies for racism. Institutional analysis reveals that racism occurs through the purposeful embrace of racial institutions, but also through the nonconscious subscription to racial background understandings and practices. In the latter instances, explicit references to race occur infrequently; to the contrary, emphatic, heartfelt denials of racist motives often accompany institutional racism. Moreover, institutional analysis shows that remedying nonintentional racism requires openly addressing the role of racial institutions in human cognition. To end nonconscious reliance on racial institutions requires frank references to race; without such attention, racial institutions will persist, unrecognized but prevalent.

The Court seems to be developing an equal protection jurisprudence that defines racism both too narrowly (race must be openly considered) and too broadly (any consideration of race constitutes racism). The Supreme Court errs when it suggests that racism-always and exclusively-involves the open consideration of race. Indeed, by disregarding institutional racism, the Court errs fundamentally: It understands racism exactly backwards. Institutional racism easily occurs without conscious thought of race, and consciously considering race may stem from a desire to ameliorate rather than to perpetuate institutional racism. In short, the Court's current understanding of racism is indefensible relative to institutional racism.

\section{b. Reserving the Power To Define Racism}

Current equal protection decisions not only rework Davis's understanding of racism, but also depart from Davis's refusal to define racism for all government purposes. Davis explicitly countenanced government remedies to racial discrimination that conceptualized racism more robustly than the Court thought appropriate for constitutional analysis. ${ }^{444}$ In contrast, many recent equal protection decisions demonstrate the current Court's willingness to impose its restrictive understanding of racism on other branches of government. Current equal protection jurisprudence not only depends upon an erroneous understanding of racism; it increasingly imposes that defective understanding on all state actors.

Shaw demonstrates this trend with respect to antidiscrimination statutes, insofar as the Court there reversed reforms undertaken pursuant to the Voting Rights Act because such redistricting ran afoul of the Court's evolving equation of a reliance on race with racism. ${ }^{445}$ Cases concerning

the opposite impulse: a desire to foster equality in society. ... The consistency that the Court espouses would disregard the difference between a "No Trespassing" sign and a welcome mat.

Adarand Constructors v. Peña, 515 U.S. 220, 243, 245 (1995) (Stevens, J. dissenting).

444. See supra note 426.

445. The Court's tendency to impose its own definition of racism on antidiscrimination law extends beyond the Voting Rights Act. In Wards Cove Packing Co. v. Atonio, 490 U.S. 642 
race-conscious remedies, however, such as Croson and Adarand, more powerfully evidence this new dynamic. In Croson, for instance, the City of Richmond established a set-aside program for city contracts aimed at increasing the number of minority contractors in the construction industry. Richmond justified its program on the grounds that African Americans constituted about half the city's population, while just two-thirds of one percent of Richmond's construction dollars dispensed in the five years prior to the set-aside had gone to minority-owned prime contractors. ${ }^{+46}$ The Court rejected Richmond's plan, ruling squarely for the first time that strict scrutiny applies to remedial action. More to the point here, however, the Court also explicitly limited the sort of racism that government may attempt to remedy.

The Court castigated Richmond for resting its program on "an amorphous claim" of past discrimination, ${ }^{47}$ on "sheer speculation" regarding the effects of longstanding racism, 148 and on "unsupported assumption[s]" about the overwhelmingly White Richmond construction industry. ${ }^{449}$ The Court held that government actors may implement raceconscious remedies only when they address specifically identified practices of discrimination, practices "approaching a prima facie case of a constitutional or statutory violation." ${ }^{450}$ In so holding, the Court specifically

(1989), the Court reaffirmed the ability of Title VII to reach disparate impact cases, but imposed a new hurdle on plaintiffs by requiring that they identify "a specific or particular employment practice that has created the disparate impact under attack." Id. at 657. The Coun explained that to allow plaintiffs to prevail without "specifically showing that each challenged practice has a significantly disparate impact... would result in employers being polentially liable for "the myriad of innocent causes that may lead to statistical imbalances in the composition of their work forces." Id. (quoting Watson v. Fort Worth Bank \& Trust, 487 U.S. 977,992 (1988)) (emphasis added). The reference to "innocent causes," when used to justify a heightened cvidentiary burden requiring the identification of specific discriminatory practices, seems to import into disparate impact doctrine a concern for motives and ill-intent, even as it implies that racially disproportionate results are not themselves generally indicative of racial discrimination. See infra note 450 .

446. See City of Richmond v. J.A. Croson Co., 488 U.S. 469. 534 (1989) (Marshall, J., dissenting).

447. Id. at 499 (" [A]n amorphous claim that there has been past discrimination in a particular industry cannot justify the use of an unyielding racial quota.").

448. Id. ("It is sheer speculation how many minority firms there would be in Richmond absent past societal discrimination.").

449. Id. at 502 ("To a large extent, the set-aside of subcontracting dollars seems to rest on the unsupported assumption that white prime contractors simply will not hire minority firms."). Criticizing Croson, Patricia Williams chastised the Coun for what she termed a hypnotic campaign of "adjectival dismissiveness." Patricia Williams, Legal Storytelling: The Obliging Shell: An Informal Essay on Formal Equal Opporiuniry, 87 MICH. L. REV. 2128. 2129 (1989).

450. Croson, 488 U.S. at 500 (Marshall, J., dissenting). The requirement that government actors identify specific discriminatory practices as a predicate for cstablishing a remedial program seems similar to the requirement of evidentiary specificity recently imposed by the Court on plaintiffs seeking to establish disparate impact claims under Title VII. See supra note 445 . In both instances, the Court conjures a model of racism in which disproportionate hams to minority communities are presumed to be the product of natural or "innocent" causes, with the burden on the harmed parties to demonstrate otherwise. Put differently, under this model. "maism" is presumed not to operate, even in the context of gross racial disparities, unless identified and proved with particularity. As john powell remarks, "the Court has adopted the perspective that racial inequality is the result of natural or legitimate causes." powell. supra note 355, at 904. 
rejected as "rather stark" the proposition that "the city of Richmond enjoys sweeping legislative power to define and attack the effects of prior discrimination." ${ }^{451}$ The specific exclusion of definitional power is telling, for in its various decisions the Court in fact curtails the power of Congress and the states to comprehend racism as they think appropriate for the purposes of achieving social justice. The Supreme Court increasingly arrogates the power to label some social practices "racism," and hence remediable, not only constitutionally, but by statute or affirmative action. ${ }^{432}$

Washington v. Davis limited the reach of the Constitution to instances of purposeful discrimination. Nevertheless, Davis left room for Congress and others to define racism in alternative ways, and to fashion corresponding remedies. Institutional racism theory spotlights the importance of fashioning remedies for policies and practices that impose disproportionate harms on minorities, irrespective of whether accompanied by conscious racial animus. Path analysis, in particular, emphasizes the potential for persons to engage in racism even when they are convinced that racial concerns play no part in motivating their actions. Racial statusenforcement reflects not only the latent effects of past purposeful racism, but the contemporary prevalence of institutional racism. Institutional analysis makes evident that effects-based approaches are necessary to address not simply the present results of past discrimination, amorphous and attenuated, but also the current manifestations of ongoing institutional racism, robust and real.

The Supreme Court errs not only by fundamentally misapprehending racism, but also by imposing this flawed conception on others. The Court need not, of course, constitutionalize an effects approach; yet, at a minimum, the Court must leave room for government to address discriminatory racial impact. Institutional racism necessitates disparate impact approaches; antidiscrimination laws or racial remediation strategies

451. Croson, 488 U.S. at 486 (O'Connor, J.) (emphasis added).

452. With respect to Congress in particular, it is troubling that the Supreme Court now treats Section 1 of the Fourteenth Amendment, prohibiting states from denying to any person within their jurisdiction the equal protection of the laws, as vesting in the Court the sole authority to define racism, in derogation of Section 5's grant to Congress of the power to enforce the provisions of the Amendment by appropriate legislation. One wonders whether cases such as Katzenbach v. Morgan, 384 U.S. 641 (1966), remain within the constitutional memory of the Court. That case specifically rejected the argument that Congress may do no more under the powers accorded to it by Section 5 than legislate against state action that would otherwise be found unconstitutional under Section 1:

A construction of $\S 5$ that would require a judicial determination that [state actions] precluded by Congress violated the Amendment, as a condition of sustaining the congressional enactment, would depreciate both congressional resourcefulness and congressional responsibility for implementing the Amendment. It would confine the legislative power in this context to the insignificant role of abrogating only those state laws that the judicial branch was prepared to adjudge unconstitutional ....

By including $\S 5$ the draftsmen sought to grant to Congress, by a specific provision applicable to the Fourteenth Amendment, the same broad powers expressed in the Necessary and Proper Clause.

Id. at 648-50 (footnote omitted). 
founded on models of intentional discrimination cannot and will not curtail institutional racism's harmful workings. The Supreme Court undermines efforts to bring about racial equality when it imposes a model of racism predicated on purposeful action, or worse, on the mere consideration of race. ${ }^{453}$

\section{Social Costs}

An institutional analysis of racism raises doubts about the wisdom of limiting the reach of the Equal Protection Clause to cases of purposeful racism, and of similarly limiting all government responses to racial inequality. In addition, however, it paints a disturbing picture of the social costs imposed by the purposeful racism limit. Here, the East Los Angeles cases speak volumes. In the face of evidence showing that over a twelveyear period Mexican Americans counted for one of every seven persons in Los Angeles but only one of every fifty-eight grand jurors, ${ }^{\text {sis }}$ the trial courts' findings of no constitutional violation imposed substantial harms. These decisions deprived the defendants of the right to a grand jury selected without bias, confirmed in the minds of the defendants and community members their social marginalization, continued the exclusion of Mexican Americans from an important organ of democratic government, and blessed the discriminatory practices of the Los Angeles superior court with the imprimatur of legal legitimacy. These deleterious costs, although visited narrowly on the Mexican-American community in East Los Angeles, nevertheless herald similar harms imposed across this country through equal protection law's exclusive preoccupation with "purposeful racism."

Recall $\mathrm{McCleskey,} \mathrm{the} \mathrm{Georgia} \mathrm{death} \mathrm{penalty} \mathrm{case.}{ }^{455}$ Or consider welfare cases such as Dandridge v. Williams ${ }^{456}$ and Jefferson v. Hackney, ${ }^{457}$ funding families with children at significantly lower levels than persons in other welfare categories (for instance, the aged). The Court found no

453. Cass Sunstein argues that for reasons of institutional and democratic competence, courts should not engage in the sorts of sweeping judgments that a disproportionate-impact approach to equal protection would seem to require. See Cass $\mathrm{R}$. Sunstein. Interpreting Statutes in the Regulatory State, 103 HARV. L. REV. 405, 472 (1989) ("If courts held that a disproportionate effect sufficed to raise constitutional doubts, a wide variety of govemmental policies would be seriously questioned-an extremely intrusive outcome that might be inappropriate in light of the properly limited role of the judiciary in American government."). By the same token, however, he also argues that courts should not preclude legislative branches of government from engaging in exactly those sorts of judgments. See Sunstein, Affimative Action, supra notc 414, at 1315 ("No clear constitutional commitment forbids affirmative action programs.... It is imperative that constitutional law not be used to strike down political judgments about which reasonable people differ and to which the Constitution does not clearly speak."); see also Sunstcin, Anricaste, supra note 414, at 2440 ("[L]egislative and administrative bodies, with their superior democratic pedigree and fact-finding capacities, can better implement the [anticaste] principle.").

454. See supra note 81 and accompanying text.

455. McCleskey v. Kemp, 481 U.S. 279 (1987); see also supra note 427 and accompanying text.

456. 397 U.S. 471 (1970).

457. 406 U.S. 535 (1972). 
constitutional violation in these cases, despite the fact that the challenged state action disproportionately harmed nonwhite families, because the Court saw no discriminatory purpose. Again, one does not need institutional analysis to measure such harms to minority communities. Institutional racism theory suggests the strong probability, however, that government inflicts such harms on minorities - matters of life and death, health and welfare-not fortuitously, but partially because of their minority status. In the East Los Angeles cases, in McCleskey, in Dandridge and Jefferson, and in myriad other cases that find governmental practices constitutional despite disproportionate harm to minorities, institutional analysis most likely would demonstrate that the disproportionate injuries followed at least partially and probably substantially from institutional racism. ${ }^{458}$

Return now to the "parade of horribles" argument-Davis's contention that to extend the Equal Protection Clause beyond purposeful racism would push the Court into the untenable position of having to address "serious questions about... a whole range of tax, welfare, public service, regulatory, and licensing statutes that may be more burdensome to the poor and to the average black than to the more affluent white." ${ }^{459}$ The Court continues to repeat such concerns, perhaps most notably in McCleskey, where Justice Powell warned that “if we accepted McCleskey's claim that racial bias has impermissibly tainted the capital sentencing decision, we could soon be faced with similar claims as to other types of penalty." 460 Leading constitutional commentators have long accepted this argument as a sufficient justification for the purposeful racism limit. ${ }^{461}$

The institutional analysis of racism does more than suggest that government must be free to address racism broadly conceived; it also renders the parade-of-horribles rationale troublesome. Institutional analysis

458. I specifically chose the above poverty cases because Charles Lawrence cited thesc as beyond the appropriate reach of the Equal Protection Clause. Attempting to place pragmatic limits on equal protection, Lawrence proposed a "cultural meaning test," wherein heightened legal protection would apply if government action involved either (1) purposeful racism or (2) discriminatory impact plus “cultural meaning." See Lawrence, supra note 30, at 355-56. The latter was to serve as "the best available analogue for and evidence of the collective unconscious that we cannot observe directly." Id. Lawrence concluded, however, that "[p]roving racial meaning under the cultural meaning test will be most difficult in cases ... challeng[ing] a governmental decision to limit subsidies to the poor for such basic human needs as food. clothing. shelter, and medical services." Id. at 376. Institutional analysis demonstrates that even in Lawrence's excluded cases, institutional racism likely infects the decision-making process. See supra notes 396-399 and accompanying text.

459. Washington v. Davis, 426 U.S. 229, 248 (1976); see also supra notes $416-417$ and accompanying text.

460. McCleskey, 481 U.S. at 315; see also Hernandez v. New York, 500 U.S. 352, 374 (1991) (O'Connor, J., concurring) ("In Washington v. Davis, we outlined the dangers of a rule that would allow an equal protection violation on a finding of mere disproportionate effect. Such a rule would give rise to an unending stream of constitutional challenges." (citation omitted)). Regarding McCleskey, Justice Brennan, in dissent, described the majority's concern as suggesting " $\mathrm{a}$ fcar of too much justice." McCleskey, 481 U.S. at 339 (Brennan, J., dissenting).

461. See, e.g., Brest, supra note 414, at 29 ("[F]or the reasons suggested by Mr. Justice White's parade of horribles in Washington $v$. Davis, [the disproportionate-impact doctrine] cannot reasonably be applied across the board." (citation omitted)). 
suggests that the Court has responded to the problem of the Fourteenth Amendment's stopping-place in the protection of racism's victims with a rationale predicated on a fundamentally flawed understanding of racism. And it shows that the "neutral" government actions the Court hopes not to evaluate do in fact impose severe injuries on minority communities-and do so not in spite of, but because of, their minority status. Courts and commentators must answer why the Equal Protection Clause curtails some racism-for example, that resulting from the conscious desire to harm minorities-while other forms remain lawful-for instance, institutional racism in taxation, welfare, public services, and so on. They should not presume to resolve this issue, however, by supposing the racial neutrality of government actions that disproportionately harm minorities but do not evince a racial purpose. Institutional analysis cautions that racial statusenforcing government action is likely to reflect institutional racism.

Institutional racism theory tells us that we must forthrightly engage the debate the Court fears in Davis and McCleskey. We must address the "serious questions" raised by government action that burdens nonwhites more than Whites. To be sure, the judiciary already weighs harms to minority communities against other social concerns-but it does so haphazardly, by labeling some action "neutral" and other programs "racebased." Courts cannot avoid balancing racial harm against competing social interests; at best, they can only hide from themselves their constant participation in this process. Such balancing will persist, but it should not continue in a manner that ignores new understandings of racism's various forms.

\section{Some Normative Implications of an Institutional Account of Racism}

An institutional analysis of race may engender despair. It is disheartening to understand racism as endemic, difficult to eradicate, and, above all, effectively misunderstood and misaddressed by current equal protection law. In addition, institutional racism theory may provoke frustration. On one level, the relatively bloodless language of institutions fails to capture the terrible power of racism. On another, the use of such language exculpates social actors and society in general by locating harm to minorities in hidden cognitive dynamics.

Nevertheless, the pallid language of institutionalism is normatively appropriate. Script and path racism remain shrouded from observation precisely because they draw on institutions, the received social grammars on which all persons rely. Racial institutions and institutionalized racial practices form part of the world-known-in-common; they constitute the reality that we have socially constructed. It is necessary, or at least appropriate, to model some racism in the relatively dry language of institutionalism because the racism of institutions elicits barely any 
attention, and still less emotion and uproar. It exhibits no fiery hatred, reveals no easily singled out and easily condemned culprit or decision, stimulates no fury or moment of truth. There is only the steady, unremarkable progression of reality, the day-to-day doldrums of racial discrimination. The language that explains the tedious creep of institutional racism cannot be suffused with incendiary imagery, for such language would not accurately reflect the social processes described. The heat of moral condemnation warranted by the inequitable results of institutional racism misdescribes its monotonous, unquestioned, sedimentary progress. ${ }^{462}$

All of that said, this Article has sought to demonstrate that the social processes described herein are racism. Though they exhibit no purposeful embrace of racial discrimination, they nevertheless involve action, prompted by cognitive reliance on racial institutions, that enforces racial status. Perhaps similar levels of moral culpability and remedial obligation do not attach to the person who engages in -or to the society that tolerates-script or path, rather than purposeful, racism. And perhaps institutional racism will prove far more difficult to disestablish than the intentional sort. Nevertheless, nature did not institutionalize racial practices: We did, and that imposes on us the responsibility for their persistence and remediation. We must respond, however, in institutional terms, for such terms measure the differences in our understandings of the world, and indeed of the very requirements of justice. ${ }^{433}$

With the ability to counteract racism comes the responsibility to do so, to realize our national ideals, to achieve an increased measure of social equality. To talk of institutional racism may be to engage in dry analysis, but to posit institutional racism places at center stage our responsibility to address largely unrecognized processes of organizational and social life that harm our society.

462. $C$. HANNAH ARENDT, EICHMANN IN JERUSALEM: A REPORT ON THE BANALITY OF EvIL (1963). While I hesitate to invoke the Holocaust, Arendt's depiction of human evil as sometimes incremental and utterly ordinary resonates with the depiction of institutional racism that I advance here.

463. Thus the epigraph that began this Article:

When individuals disagree on elementary justice, their most insoluble conflict is between institutions.... The more severe the conflict, the more useful to understand the institutions that are doing most of the thinking. ... Only changing institutions can help. We should address then, not individuals, and address them continuously, not only in crises.

DOUGLAS, supra note 1 , at 125-26. 


\section{APPENDICES}

All excerpts in the following appendices are taken from the transcript of the Motion to Quash Indictment, People v. Castro, No. A-232902 (Cal. Super. Ct. 1968) [indicated in the tables as " $T$ "]. The full transcript is available in the Oscar Zeta Acosta Papers, California Ethnic and Multicultural Archives, Department of Special Collections, University of Califomia, Santa Barbara.

\section{APPENDIX A: EXCERPTS FROM THE EAST LA 13 TRANSCRIPT REGARDING GRAND JURY NOMINEES}

This Appendix compiles in table format each judge's grand jury nominees, based on the judges' testimony in East LA 13. The tables include the judges' names, the names of the nominees, the years of their nominations where available, and the judges' relationships to the nominees, drawn wherever possible from the judges' own words.

The tables characterize the relationship between judges and nominees in the following terms: Friend; acquaintance through a church, civic organization, or club (abbreviated as Church, Civic Org., or Club); Business Acquaintance; Spouse of Acquaintance; Neighbor; Family Member; Recommended; No Recollection; and Uncharacterized. Often the judges described a single nominee such that more than one characterization applies.

JUDGE EUGENE H. BREITENBACH T426

\begin{tabular}{|c|c|c|}
\hline Nominee & Relationship & Characterization \\
\hline $\begin{array}{c}\text { Carol W. Parcher } \\
1959\end{array}$ & $\begin{array}{l}\text { "He is the editor, and I } \\
\text { believe the publisher, of the } \\
\text { Glendale News Press." Knew } \\
\text { him for "several years" and } \\
\text { considered him "a personal } \\
\text { friend." T428 }\end{array}$ & Friend \\
\hline $\begin{array}{l}\text { Helen Erickson } \\
1959\end{array}$ & $\begin{array}{l}\text { "She is a neighbor. ... [I } \\
\text { have known her] since we } \\
\text { moved to our residence about } \\
\text { a block from where she lives } \\
\text { in } 1940 . " \text { T429 }\end{array}$ & Neighbor \\
\hline Harland J. Nissen & $\begin{array}{l}\text { "I first became acquainted } \\
\text { with Mr. Nissen when we } \\
\text { were both on the recreation } \\
\text { facilities committee of the } \\
\text { Los Angeles Junior Chamber } \\
\text { of Commerce in the early } \\
\text { 1930s." T429 }\end{array}$ & $\begin{array}{c}\text { Church, Civic Org., or } \\
\text { Club }\end{array}$ \\
\hline $\begin{array}{c}\text { Victor Montgomery } \\
1960\end{array}$ & $\begin{array}{l}\text { "I know-knew him very } \\
\text { well," since } 1948 . \text { T429-30 }\end{array}$ & Friend \\
\hline
\end{tabular}




\begin{tabular}{|c|c|c|}
\hline Nominee & Relationship & Characterization \\
\hline Lindley M. Bryant & $\begin{array}{l}\text { "Mr. Bryant was a member } \\
\text { of the board of trustees of the } \\
\text { Emanuel Presbyterian } \\
\text { Church, } 3300 \text { Wilshire } \\
\text { Boulevard, at the same time I } \\
\text { was, approximately } 20 \text { years } \\
\text { ago, and I have known him } \\
\text { very well ever since as a } \\
\text { member of that same } \\
\text { church." T430 }\end{array}$ & $\begin{array}{l}\text { Church, Civic Org., or } \\
\text { Club }\end{array}$ \\
\hline Eleanor Hiller & $\begin{array}{l}\text { "I first met Mrs. Hiller when } \\
\text { we were both on the Los } \\
\text { Angeles Community } \\
\text { Council .... This was } \\
\text { approximately } 1933 \text {, and I } \\
\text { have known her of course } \\
\text { ever since." T430 }\end{array}$ & $\begin{array}{l}\text { Church, Civic Org., or } \\
\text { Club }\end{array}$ \\
\hline Herman J. Garretson & $\begin{array}{l}\text { "I knew him first as president } \\
\text { of the Iowa Association of } \\
\text { Southern California. This was } \\
\text { approximately 1932, and I } \\
\text { have known him in the Iowa } \\
\text { Association and in other } \\
\text { social contacts ever since." } \\
\text { T431 }\end{array}$ & $\begin{array}{c}\text { Church, Civic Org., or } \\
\text { Club }\end{array}$ \\
\hline Mary Jane Kidd & $\begin{array}{l}\text { "I first met Mrs. Kidd as a } \\
\text { co-member of the Mental } \\
\text { Clinic Organization in } \\
\text { Glendale for children. This } \\
\text { was approximately } 20 \text { years } \\
\text { ago." T431 }\end{array}$ & $\begin{array}{c}\text { Church, Civic Org., or } \\
\text { Club }\end{array}$ \\
\hline Louise Sellman & $\begin{array}{l}\text { "I first met her husband when } \\
\text { we were neighbors in West } \\
\text { Lost Angeles ... [in] } \\
\text { approximately 1932, and I } \\
\text { have known him ever since as } \\
\text { an accountant and a personal } \\
\text { friend." T431-32 }\end{array}$ & Spouse of Acquaintance \\
\hline Ruth Darsie & $\begin{array}{l}\text { "She was a widow of Darsie } \\
\text { L. Darsie, the sports writer } \\
\text { for the Herald-Examiner, and } \\
\text { I knew her as a neighbor } \\
\text { living approximately three } \\
\text { blocks from where I have } \\
\text { lived ... since } 1940 \text { in } \\
\text { Glendale." T432 }\end{array}$ & Neighbor \\
\hline Ross G. Van Gundy & $\begin{array}{l}\text { "I met him as a fellow } \\
\text { member of the board of } \\
\text { trustees of Emanuel } \\
\text { Presbyterian Church, and as a } \\
\text { member of that church, and } \\
\text { on the sessions of that } \\
\text { church." T432 }\end{array}$ & $\begin{array}{c}\text { Church, Civic Org., or } \\
\text { Club }\end{array}$ \\
\hline
\end{tabular}




\begin{tabular}{|c|l|c|}
\hline Nominee. & \multicolumn{1}{|c|}{ Relationship } & Characterization \\
\hline 1965 & $\begin{array}{l}\text { "I have known him as an } \\
\text { acquaintance for about } \\
\text { three-approximately three } \\
\text { years, and by reputation." } \\
\text { Recommended by “a fellow } \\
\text { member of the Los Angeles } \\
\text { Lions Club." T432,434 }\end{array}$ & \\
\hline Anthony Fogo & $\begin{array}{l}\text { "I first met him as a fellow } \\
\text { member and later fellow } \\
\text { board member of the Los } \\
\text { Angeles Junior Chamber of } \\
\text { Commerce in the 1930s, and }\end{array}$ & Church, Civic Org., or \\
& $\begin{array}{l}\text { I have known him of course } \\
\text { very well ever since." T433 }\end{array}$ & \\
\hline Eleanor Austin & $\begin{array}{l}\text { "She and my wife were both } \\
\text { members of the same parent- } \\
\text { teacher association in } \\
\text { Glendale approximately 15 } \\
\text { years ago, and I have known } \\
\text { her and her husband all } \\
\text { during this time, socially and } \\
\text { in various other civic and } \\
\text { other organizations in } \\
\text { Glendale and Los Angeles." } \\
\text { T433 }\end{array}$ & Church, Civic Org., or \\
& Club \\
\hline
\end{tabular}

JUDGE JOSEPH L. CALL T366

\begin{tabular}{|c|l|c|}
\hline Nominee & \multicolumn{1}{|c|}{ Relationship } & Characterization \\
\hline Frank Fensch & $\begin{array}{c}\text { "He was outstanding in the } \\
\text { Alcoholics Anonymous } \\
\text { movement and was for years, } \\
\text { and in my dealings with } \\
\text { unfortunate alcoholics in the } \\
\text { Municipal Cour, in that } \\
\text { capacity I ran into him." } \\
\text { T371 }\end{array}$ & Uncharacterized \\
\hline Mrs. Marius Biencourt & $\begin{array}{l}\text { "I knew her-I became } \\
\text { acquainted with her as a } \\
\text { forthright member of the } \\
\text { community, a housewife, if I } \\
\text { remember correctly." T376- } \\
\text { 77 }\end{array}$ & \\
\hline Cornwall Jackson & $\begin{array}{l}\text { "Well, he's a-he has been a } \\
\text { friend for 25, 30 years. He is } \\
\text { not an intimate friend, but he } \\
\text { is a friend of long-standing } \\
\text { acquaintance." A member of } \\
\text { the Los Angeles Tennis Club } \\
\text { "since the middle '30s." } \\
\text { T377, 396 }\end{array}$ & Church. Civic Org., or \\
\hline
\end{tabular}




\begin{tabular}{|c|c|c|}
\hline Nominee & Relationship & Characterization \\
\hline Grace Van der Hof & $\begin{array}{l}\text { "I would approximate that I } \\
\text { have known Mrs. Van der } \\
\text { Hof since } 1953 \text {.... [She is] } \\
\text { a very good friend." A } \\
\text { member of the Los Angeles } \\
\text { Tennis Club. T378, } 395\end{array}$ & $\begin{array}{l}\text { Friend; } \\
\text { Church, Civic Org., or } \\
\text { Club }\end{array}$ \\
\hline Patricia Yeomans & $\begin{array}{l}\text { "I've known her since the } \\
\text { middle '30s as a child, almost } \\
\text { as a very young adolescent } \\
\text { girl at the time. She's an } \\
\text { outstanding housewife now." } \\
\text { Daughter and spouse of Los } \\
\text { Angeles Tennis Club } \\
\text { members. T378, } 396\end{array}$ & $\begin{array}{l}\text { Church, Civic Org., or } \\
\text { Club }\end{array}$ \\
\hline Dora Rombeau & $\begin{array}{l}\text { "She is the wife of Dr. } \\
\text { Rombeau, an outstanding } \\
\text { physician, I believe, in } \\
\text { Burbank. I know Dr. } \\
\text { Rombeau and Mrs. Rombeau } \\
\text { because they have been } \\
\text { members of the Los Angeles } \\
\text { Tennis Club since the early } \\
\text { '50s... I see them twice a } \\
\text { week on the courts at the Los } \\
\text { Angeles Tennis Club, and } \\
\text { have since 1950." T379 }\end{array}$ & $\begin{array}{c}\text { Church, Civic Org., or } \\
\text { Club; } \\
\text { Spouse of Acquaintance }\end{array}$ \\
\hline Maureen Campbell & $\begin{array}{l}\text { "I place the time through her } \\
\text { husband, Mr. Alex Campbell } \\
\text { of the Los Angeles Herald, } \\
\text { and that would go back to the } \\
\text { time he joined the Los } \\
\text { Angeles Tennis Club .... I } \\
\text { joined there in 1932, '33, and } \\
\text { Campbell came in in about } \\
1955 \text {, and that is when I met } \\
\text { his wife, so I'd say from } \\
1955 \text { "T379 }\end{array}$ & $\begin{array}{c}\text { Church, Civic Org., or } \\
\text { Club; } \\
\text { Spouse of Acquaintance }\end{array}$ \\
\hline George Goman & $\begin{array}{l}\text { Knows him "very well" as a } \\
\text { member of the Los Angeles } \\
\text { Tennis Club "roughly since } \\
\text { 1950." T380 }\end{array}$ & $\begin{array}{l}\text { Church, Civic Org., or } \\
\text { Club }\end{array}$ \\
\hline Leona McNeill & $\begin{array}{l}\text { "I knew her through her } \\
\text { husband, Dr. Robert McNeill, } \\
\text { who is an outstanding } \\
\text { surgeon in the city .... [S]he } \\
\text { plays [at the Los Angeles } \\
\text { Tennis Club] on weekends. } \\
\text { She may have what is known } \\
\text { as an associate membership } \\
\text { through her husband, who is } \\
\text { a member." T380-81 }\end{array}$ & $\begin{array}{l}\text { Church, Civic Org., or } \\
\text { Club; } \\
\text { Spouse of Acquaintance }\end{array}$ \\
\hline Elizabeth Hunter & $\begin{array}{l}\text { Acquainted with her through } \\
\text { the Los Angeles Tennis Club. } \\
\text { T398 }\end{array}$ & $\begin{array}{l}\text { Church, Civic Org., or } \\
\text { Club }\end{array}$ \\
\hline
\end{tabular}


JUDGE KENNETH N. CHANTRY

T559

\begin{tabular}{|c|c|c|}
\hline Nominee & Relationship & Characterization \\
\hline Elmer Niemoeller & $\begin{array}{l}\text { "Oh, I think I met him } \\
\text { playing golf, and probably at } \\
\text { the Wilshire Country Club. } \\
\text { I'm not sure." T561 }\end{array}$ & $\begin{array}{c}\text { Church, Civic Org., or } \\
\text { Club }\end{array}$ \\
\hline Dalton Adams & $\begin{array}{l}\text { "I know Mr. Adams quite } \\
\text { well. ... [He is] somebody } \\
\text { that I knew at Wilshire } \\
\text { Country Club, and also a } \\
\text { businessman, and I would say } \\
\text { I have known him since at } \\
\text { least } 10,12,15 \text { years." T562 }\end{array}$ & $\begin{array}{l}\text { Church, Civic Org.. or } \\
\text { Club }\end{array}$ \\
\hline William Middleton & $\begin{array}{l}\text { "I know Mr. Middleton. He } \\
\text { is also a retired businessman. } \\
\text { I have known him for about } \\
\text { [10 to } 15 \text { years]. I also know } \\
\text { his son. ... [I know him } \\
\text { from] Wilshire Country } \\
\text { Club." T562 }\end{array}$ & $\begin{array}{c}\text { Church, Civic Org., or } \\
\text { Club }\end{array}$ \\
\hline Byron Reynolds & $\begin{array}{l}\text { "I know Mr. Reynolds very } \\
\text { well. I have known Mr. } \\
\text { Reynolds I believe since-I } \\
\text { hate to admit it, about } \\
1922 . . . \text {. [He is also a } \\
\text { member of Wilshire Country } \\
\text { Club], but I knew him... } \\
\text { before I was ever a member } \\
\text { of the country club." T562- } \\
63\end{array}$ & $\begin{array}{c}\text { Church, Civic Org., or } \\
\text { Club }\end{array}$ \\
\hline E.W. Beck & $\begin{array}{l}\text { "Well, I met him at the club } \\
\text { also. I have known Mr. Beck } \\
\text { for probably five, six, seven, } \\
\text { eight years. He is a retired oil } \\
\text { man, if I am not mistaken." } \\
\text { T563 }\end{array}$ & $\begin{array}{c}\text { Church, Civic Org., or } \\
\text { Club }\end{array}$ \\
\hline Mrs. Davis Pye & $\begin{array}{l}\text { "Yes, I know her, but I don't } \\
\text { know her very well. I think I } \\
\text { got her name from someone } \\
\text { else, a friend,... [s]omeone } \\
\text { at the club." T563 }\end{array}$ & Recommended \\
\hline Harry Moore & $\begin{array}{l}\text { "Yes, I know Mr. Moore. Mr. } \\
\text { Moore is a Certified Public } \\
\text { Accountant, and I think he is } \\
\text { with the Ross Montgomery } \\
\text { firm. I believe I met him } \\
\text { when he was on the Harbor } \\
\text { Commission of the City of } \\
\text { Los Angeles.... He also is a } \\
\text { member of the Wilshire } \\
\text { Country Club." T564 }\end{array}$ & $\begin{array}{l}\text { Church, Civic Org., or } \\
\text { Club }\end{array}$ \\
\hline Ralph E. Davis & $\begin{array}{l}\text { "I think I have met him at the } \\
\text { club, if I'm not mistaken, but } \\
\text { I again wouldn't want to be } \\
\text { tied down to that." T564 }\end{array}$ & $\begin{array}{c}\text { Church, Civic Org., or } \\
\text { Club }\end{array}$ \\
\hline
\end{tabular}


JUDGE LEONARD A. DIETHER

T512

\begin{tabular}{|c|c|c|}
\hline Nominee & Relationship & Characterization \\
\hline Denman Gamble & $\begin{array}{l}\text { "Oh, I've known him from } \\
10 \text { to } 15 \text { years socially." } \\
\text { T515 }\end{array}$ & Friend \\
\hline Ruth Shepard & $\begin{array}{l}\text { "I have known her for } 20 \\
\text { years, as a friend and as an } \\
\text { associate." T515 }\end{array}$ & $\begin{array}{c}\text { Friend; } \\
\text { Business Acquaintance }\end{array}$ \\
\hline Leon L. Horchitz & $\begin{array}{l}\text { "[I have known him s]ocially } \\
\text { for } 15,20 \text { years." T516 }\end{array}$ & Friend \\
\hline Bruce V. Reagon & $\begin{array}{l}\text { "I have known him for about } \\
\text { approximately } 35 \text { years in a } \\
\text { business capacity.... Oh, } \\
\text { yes; [he is] a friend also." } \\
\text { T516 }\end{array}$ & $\begin{array}{c}\text { Friend; } \\
\text { Business Acquaintance }\end{array}$ \\
\hline Ione Sharp Gibboney & $\begin{array}{l}\text { "I have known her two or } \\
\text { three years, a friend." T516 }\end{array}$ & Friend \\
\hline Frances R. Wilcox & $\begin{array}{l}\text { "[I have known him o]h, } \\
\text { probably } 15,20 \text { years; [he is } \\
\text { a] friend." T516 }\end{array}$ & Friend \\
\hline
\end{tabular}

JudGe GeORGE A. DOCKWEILER $\mathrm{T} 402$

\begin{tabular}{|c|c|c|}
\hline Nominee & Relationship & Characterization \\
\hline Thomas Barrington & $\begin{array}{l}\text { "Yes, he was a neighbor of } \\
\text { mine when I lived at } 2040 \\
\text { Cummings Drive, right off } \\
\text { Los Feliz. Thomas } \\
\text { Barrington lived just around } \\
\text { the corner, and I knew him } \\
\text { for some-well, we lived in } \\
\text { Los Feliz for about } 20 \text { years, } \\
\text { and he was a neighbor, and I } \\
\text { think he lived there } \\
\text { practically all that time." } \\
\text { T404 }\end{array}$ & Neighbor \\
\hline $\begin{array}{c}\text { Joseph Raeburn } \\
1959,1960\end{array}$ & $\begin{array}{l}\text { "He was also a neighbor of } \\
\text { mine. He was connected with } \\
\text { the Security First National } \\
\text { Bank, in the real estate } \\
\text { department, and he was } \\
\text { around the corner when I } \\
\text { lived on Cummings Drive, } \\
\text { and he was a neighbor of Mr. } \\
\text { Barrington." T404 }\end{array}$ & Neighbor \\
\hline $\begin{array}{c}\text { Roy T. Mote } \\
1960\end{array}$ & $\begin{array}{l}\text { "I think that name was } \\
\text { suggested to me by Joseph } \\
\text { Raeburn in whom I had a lot } \\
\text { of confidence." T405 }\end{array}$ & Recommended \\
\hline Constance H. Jones & $\begin{array}{l}\text { "I think that name came from } \\
\text { Mrs. Raeburn, my neighbor." } \\
\text { T406 }\end{array}$ & Recommended \\
\hline
\end{tabular}




\begin{tabular}{|c|c|c|}
\hline Nominee & Relationship & Charactcrization \\
\hline Monica Gorman & $\begin{array}{l}\text { "She is a friend. I knew her } \\
\text { husband very well, and met } \\
\text { Monica through her } \\
\text { husband." T406 }\end{array}$ & $\begin{array}{c}\text { Friend; } \\
\text { Spouse of Acquaintance }\end{array}$ \\
\hline $\begin{array}{c}\text { Abraham Abell } \\
1964\end{array}$ & $\begin{array}{l}\text { "[I've known him f]ive or six } \\
\text { years. . . . He is an auctioneer. } \\
\text { I became acquainted with } \\
\text { him-I have gone down to } \\
\text { his auction house." T406-07 }\end{array}$ & Business Acquaintance \\
\hline $\begin{array}{c}\text { Albert Robbins } \\
1964\end{array}$ & $\begin{array}{l}\text { "I don't know Robbins } \\
\text { personally. I met him, I think, } \\
\text { socially, but Robbins, his } \\
\text { name was presented to me as } \\
\text { being a competent and well- } \\
\text { qualified juror through Mr. } \\
\text { Lindell Young, an attomey." } \\
\text { T407 }\end{array}$ & Recommended \\
\hline Donald McGrath & $\begin{array}{l}\text { "Oh, yes, he is my neighbor. } \\
\text { He lives on the corner of } \\
\text { Irving and First Street." T408 }\end{array}$ & Neighbor \\
\hline Mary Stella Raeburn & $\begin{array}{l}\text { "That is Joseph Racburn's } \\
\text { wife, my neighbor when I } \\
\text { lived on Cummings Drive. } \\
\text { She is still-Of course, I } \\
\text { knew her well." T409 }\end{array}$ & Neighbor \\
\hline Helen McMillen & $\begin{array}{l}\text { "Helen McMillen is my } \\
\text { wife's father's brother's wife. } \\
\text { Her husband was formerly } \\
\text { president of the McMillen } \\
\text { Petroleum Corporation, } \\
\text { which is still in existence, but } \\
\text { no longer controlled by the } \\
\text { family." T409 }\end{array}$ & Family Member \\
\hline William Rasch & $\begin{array}{l}\text { "William Rasch is a } \\
\text { contractor. a builder, and I } \\
\text { met Mr. Rasch, at first blush, } \\
\text { at the Newman Club." T409 }\end{array}$ & $\begin{array}{c}\text { Church, Civic Org., or } \\
\text { Club }\end{array}$ \\
\hline Pauline Helm & $\begin{array}{l}\text { "Yes. Pauline Helm I have } \\
\text { seen out socially. I am not too } \\
\text { well personally acquainted. I } \\
\text { have seen her, but I know her } \\
\text { background and her family, } \\
\text { and so forth. ... I have } \\
\text { known her for years." T409- } \\
10\end{array}$ & Friend \\
\hline Mary Ellen Day & $\begin{array}{l}\text { "That's another neighbor of } \\
\text { mine ... . I first became } \\
\text { acquainted with her when I } \\
\text { moved into the area about } \\
\text { nine or ten years ago." T410 }\end{array}$ & Neighbor \\
\hline
\end{tabular}


JUDGE EMMETT E. DOHERTY

T320

\begin{tabular}{|c|c|c|}
\hline Nominee & Relationship & Characterization \\
\hline $\begin{array}{c}\text { Joseph P. Carroll } \\
1960\end{array}$ & $\begin{array}{l}\text { "[He was] a substantial } \\
\text { businessman, reputable } \\
\text { member of the } \\
\text { community.... [I've known } \\
\text { him for] approximately } 20 \\
\text { years." T323 }\end{array}$ & Business Acquaintance \\
\hline Mrs. Earl B. Gilmore & $\begin{array}{l}\text { "I was associated with her } \\
\text { husband in business, Earl } \\
\text { Gilmore," and knew her for } \\
\text { "[p]robably } 25 \text { years, maybe } \\
\text { longer." T323-24 }\end{array}$ & Spouse of Acquaintance \\
\hline $\begin{array}{c}\text { Marjorie Mount } \\
1961,1962,1963,1964 \\
1965\end{array}$ & $\begin{array}{l}\text { "I knew her socially.... } \\
\text { [a]bout } 20 \text { years, probably } \\
\text { longer." T324 }\end{array}$ & Friend \\
\hline $\begin{array}{c}\text { Lombard Smith } \\
1966\end{array}$ & $\begin{array}{l}\text { Knew him "socially" for } \\
\text { "[a]bout } 15 \text { years." T324-25 }\end{array}$ & Friend \\
\hline $\begin{array}{c}\text { Marguerite Lyons } \\
1966\end{array}$ & Did not recall nominee. & No Recollection \\
\hline $\begin{array}{c}\text { Joseph Buchler } \\
1967\end{array}$ & $\begin{array}{l}\text { "He was the father of the } \\
\text { bailiff in my court, and a } \\
\text { retired businessman who } \\
\text { was-I knew of, and knew } \\
\text { him available to serve." T325 }\end{array}$ & Uncharacterized \\
\hline $\begin{array}{c}\text { Henry Fritzen } \\
1967\end{array}$ & $\begin{array}{l}\text { "I knew him for } 10 \text { years." } \\
\text { T325 }\end{array}$ & Friend \\
\hline $\begin{array}{l}\text { Mr. Porter } \\
1968\end{array}$ & $\begin{array}{l}\text { "I have known him socially } \\
\text { probably for } 20 \text { years." T326 }\end{array}$ & Friend \\
\hline
\end{tabular}

JUDGE GOSCOE O. FARLEY

T867

\begin{tabular}{|c|l|c|}
\hline Nominee & \multicolumn{1}{|c|}{ Relationship } & Characterization \\
\hline Doris Kingsley & $\begin{array}{l}\text { "She is the wife of Justice } \\
\text { Kingsley. I first knew her } \\
\text { when he was dean of U.S.C. } \\
\text { Law School." A friend. T869 }\end{array}$ & $\begin{array}{c}\text { Friend; } \\
\text { Spouse of Acquaintance }\end{array}$ \\
\hline James Markey & $\begin{array}{l}\text { "Mr. Markey is my father-in- } \\
\text { law, and at the time I } \\
\text { nominated him I must have } \\
\text { known him about 10 or 12 } \\
\text { years." T869 }\end{array}$ & Family Member \\
\hline Reverend A.J. Soldan & $\begin{array}{l}\text { "I hadn't actually known } \\
\text { him. He was recommended } \\
\text { by my father-in-law Mr. } \\
\text { Markey." T869 }\end{array}$ & Recommended \\
\hline Arthur Werner & $\begin{array}{l}\text { "He was recommended by a } \\
\text { friend of mine ... an attorney } \\
\text { in town." T870 }\end{array}$ & Recommended \\
\hline Leo Hubbard & $\begin{array}{l}\text { "He was recommended by a } \\
\text { Judge of the Municipal } \\
\text { Court ...." T871 }\end{array}$ & Recommended \\
\hline
\end{tabular}




\begin{tabular}{|c|l|c|}
\hline Nominee & \multicolumn{1}{|c|}{ Relationship } & Characterization \\
\hline Bessie Kramsky & $\begin{array}{l}\text { "She was also recommended } \\
\text { by Attomey Ralph Meyer." } \\
\text { T871 }\end{array}$ & Recommended \\
\hline
\end{tabular}

JUDGE ROBERT FEINERMAN

T546

\begin{tabular}{|c|c|c|}
\hline Nominee & Relationship & Characterization \\
\hline Rita Barschak & $\begin{array}{l}\text { "I have known Mrs. } \\
\text { Barschak for approximately } \\
10 \text { years. . . Mrs. Barschak } \\
\text { is the wife of a veterinarian } \\
\text { who has been a friend of } \\
\text { mine for many years. Dr. } \\
\text { Barschak served, and is } \\
\text { serving as a director of the } \\
\text { savings and loan which I } \\
\text { represented when I practiced } \\
\text { law. In addition, they are both } \\
\text { social friends of mine and my } \\
\text { wife's." T547-48 }\end{array}$ & $\begin{array}{c}\text { Friend; } \\
\text { Spouse of Acquaintance }\end{array}$ \\
\hline Saul Cooper & $\begin{array}{l}\text { "I have known Mr. Cooper } \\
\text { for approximately } 10 \text { years. I } \\
\text { have known him in a business } \\
\text { capacity, and I have known } \\
\text { him socially." T548 }\end{array}$ & $\begin{array}{c}\text { Friend; } \\
\text { Business Acquaintance }\end{array}$ \\
\hline Estelle Massarik & $\begin{array}{l}\text { "I have known Mrs. Massarik } \\
\text { since her marriage to Dr. } \\
\text { Massarik, which was } \\
\text { approximately } 1952 \text { or } \\
\text { "53... I have known them } \\
\text { socially and-Dr. Massarik is } \\
\text { one of my closest friends." } \\
\text { T548 }\end{array}$ & Spouse of Acquaintance \\
\hline Jules Bisno & $\begin{array}{l}\text { "I have known Mr. Bisno for } \\
\text { approximately } 20 \text { years. I } \\
\text { have known him because of } \\
\text { community service. He is an } \\
\text { active leader of the USO, } \\
\text { United Jewish Welfare Fund, } \\
\text { the Federation of - Jewish } \\
\text { Federation Council of Greater } \\
\text { Los Angeles. We both served } \\
\text { as officers of that } \\
\text { institution." T549 }\end{array}$ & $\begin{array}{c}\text { Church, Civic Org., or } \\
\text { Club }\end{array}$ \\
\hline
\end{tabular}


JUDGE RICHARD C. FILDEW T634

\begin{tabular}{|c|c|c|}
\hline Nominee & Relationship & Characterization \\
\hline L.B. Manhoff & $\begin{array}{l}\text { "Well, Mr. Manhoff was one } \\
\text { of my first clients. We were } \\
\text { also business partners, and I } \\
\text { knew Mr. Manhoff since I } \\
\text { first started practicing law in } \\
1936 . . . \text {. [He is] a very close } \\
\text { personal friend. We were } \\
\text { business associates and are } \\
\text { very close personal friends." } \\
\text { T636 }\end{array}$ & $\begin{array}{c}\text { Friend; } \\
\text { Business Acquaintance }\end{array}$ \\
\hline Tom Wyper & $\begin{array}{l}\text { "I knew Tom when he first } \\
\text { came over from Scotland and } \\
\text { established a sign business } \\
\text { known as Wyper Sign } \\
\text { Company in Pasadena.... } \\
\text { [He is a] very good friend." } \\
\text { T637 }\end{array}$ & $\begin{array}{c}\text { Friend; } \\
\text { Business Acquaintance }\end{array}$ \\
\hline Frank Tang & $\begin{array}{l}\text { "Well, Mr. Tang and I were } \\
\text { friends for many years. I } \\
\text { frequented his restaurant } \\
\text { when I practiced law, and got } \\
\text { to know both he and his wife, } \\
\text { and his brother Ken, whom I } \\
\text { saw in the 'Flower Drum } \\
\text { Song' Sunday night on } \\
\text { television." T637 }\end{array}$ & Friend \\
\hline A.H. Melcher & $\begin{array}{l}\text { "Well, I knew him as a } \\
\text { client, close personal friend, } \\
\text { and my secretary, who has } \\
\text { been my secretary for } 13 \\
\text { years, he happened to be her } \\
\text { husband...." T638 }\end{array}$ & $\begin{array}{c}\text { Friend; } \\
\text { Business Acquaintance; } \\
\text { Spouse of Acquaintance }\end{array}$ \\
\hline Ann Merrill & $\begin{array}{l}\text { "Yes, she went to school, } \\
\text { UCLA, with my wife before } \\
\text { my wife was my wife. I have } \\
\text { known her-I knew her } \\
\text { husband before she married } \\
\text { him-a very bright, } \\
\text { intelligent woman, now a } \\
\text { resident of New Mexico." } \\
\text { T638 }\end{array}$ & Friend \\
\hline Clarence Follett & $\begin{array}{l}\text { "He has been a personal } \\
\text { friend of mine for a number } \\
\text { of years." T638 }\end{array}$ & Friend \\
\hline Willard Wiener & $\begin{array}{l}\text { "He is also a personal friend } \\
\text { of mine dating back to } 1938 \text {, } \\
\text { a very close personal friend." } \\
\text { T638 }\end{array}$ & Friend \\
\hline Dominick Turinetto & $\begin{array}{l}\text { "We call him 'Chi Chi.' He } \\
\text { is also a very good friend of } \\
\text { mine." T639 }\end{array}$ & Friend \\
\hline
\end{tabular}




\begin{tabular}{|c|l|c|}
\hline Nominee & \multicolumn{1}{|c|}{ Relationship } & Characterization \\
\hline Milton Walker & $\begin{array}{l}\text { "Oh, I've known Milt since } \\
1938 \text { at least, and he is a very } \\
\text { close personal friend." T639 }\end{array}$ & Friend \\
\hline Earl Brown & $\begin{array}{l}\text { "Earl Brown I have known } \\
\text { very well." T639 }\end{array}$ & Friend \\
\hline Sam Lee & $\begin{array}{l}\text { A "close personal friend ] of } \\
\text { mine." T639 }\end{array}$ & Friend \\
\hline
\end{tabular}

\section{JUDGE JOHN FRAZER}

T527

\begin{tabular}{|c|l|c|}
\hline Nominee & \multicolumn{1}{|c|}{ Relationship } & Characterization \\
\hline William Blanchard & $\begin{array}{l}\text { "Well, I have known him } \\
\text { since about 1927. He is a } \\
\text { resident of Santa Monica, and } \\
\text { he belongs to the same lodge } \\
\text { that I belong to. As a matter } \\
\text { of fact, he was Master I think } \\
\text { of the Masonic Lodge that I } \\
\text { belonged to at one time." } \\
\text { T530 }\end{array}$ & Church, Civic Org., or \\
\hline Mildred Stevens & $\begin{array}{l}\text { "Well, I knew Mrs. Stevens' } \\
\text { mother, her-I don't believe I } \\
\text { ever knew her father, but I } \\
\text { knew her brothers and sisters. } \\
\text { I would say it goes back into } \\
\text { the 1920s sometime." T530 }\end{array}$ & \\
\hline Collis Holladay & $\begin{array}{l}\text { "Yes, I have known Collis } \\
\text { Holladay, I'd say, for } \\
\text { approximately I0 } \\
\text { years. .. He is not an } \\
\text { intimate acquaintance, but he } \\
\text { is a friend." T530-31 }\end{array}$ & Friend \\
\hline Samuel Perry & $\begin{array}{l}\text { "[I have known him] I would } \\
\text { say about seven or eight } \\
\text { years. .. He is [a friend of } \\
\text { mine]." T531 }\end{array}$ & Friend \\
\hline Warren Watkins & $\begin{array}{l}\text { "I have known him] I would } \\
\text { say probably about 10 years. } \\
\text { I have known his wife about } \\
\text { the same period." T531 }\end{array}$ & Friend \\
\hline
\end{tabular}




\begin{tabular}{|c|l|c|}
\hline Nominee & \multicolumn{1}{|c|}{ Relationship } & Characterization \\
\hline James Cantlen & "[I have known him for & Recommended \\
a]pproximately three or four & \\
& years, I would say. . He & \\
was president of the Los & \\
Angeles Chamber of & \\
Commerce, and he was aiso & \\
executive vice-president of & \\
the telephone company here & \\
at one time. ... [H]is name & \\
was suggested to me by one & \\
of the other Judges ... and & \\
& we both had a very dear & \\
& mutual friend in San & \\
& Francisco, and I knew of him & \\
by reputation. ... T532 & \\
\hline Jack Denbo & "Well, Jack Denbo is on the & Church, Civic Org., or \\
& Executive Board of the Boy & Club \\
& Scouts of America, which I & \\
& have served on for about 10 & \\
& years, and I have known him & \\
for about that period." T533 & \\
\hline
\end{tabular}

\section{JUDGE SAMUEL GREENFIELD}

T719

\begin{tabular}{|c|l|c|}
\hline Nominee & \multicolumn{1}{|c|}{ Relationship } & Characterization \\
\hline Gus Diamond & $\begin{array}{l}\text { "I have known him since } \\
\text { 1952. I met him then. He was } \\
\text { one of a group that retained } \\
\text { my services when I was then } \\
\text { in the practice of law....We } \\
\text { have known each other as } \\
\text { friends and as social }\end{array}$ & Fusiness Acquaintance \\
& acquaintances for the past 15 & \\
& years or more." T721 & \\
\hline Evelyn Grold & "She served on the jury panel & Uncharacterized \\
& in the Municipal Court of the & \\
& Beverly Hills Judicial District & \\
& when I presided in that court. & \\
& That was from 1963 to 1966. & \\
& I have not known her & \\
socially." T721 & \\
\hline
\end{tabular}

\section{JUDGE EMIL GUMPERT}

$$
\text { T293 }
$$

\begin{tabular}{|c|l|c|}
\hline Nominee & \multicolumn{1}{|c|}{ Relationship } & Characterization \\
\hline Georges M. George & "I've known him a good & Friend \\
$1959,1960,1961,1962$, & many years socially and \\
$1963,1964,1965,1966$, & personally." T295 & \\
1967,1968 & & \\
\hline
\end{tabular}




\begin{tabular}{|c|l|c|}
\hline Nominee & \multicolumn{1}{|c|}{ Relationship } & Characterization \\
\hline 1959 & $\begin{array}{l}\text { "She was my neighbor. She } \\
\text { lived directly across the street } \\
\text { from me. I had a social } \\
\text { relationship with her and saw } \\
\text { her frequently, and conversed } \\
\text { with her frequently; in fact. } \\
\text { sometimes it was almost a } \\
\text { daily occurrence when we } \\
\text { were out walking. I knew her } \\
\text { quite well." T303-04 }\end{array}$ & \\
& $\begin{array}{l}\text { "I knew him intimately. He } \\
\text { was my brother-in-law." } \\
\text { T304 }\end{array}$ & Family Member \\
\hline Arthur Kenner & \\
\hline
\end{tabular}

\section{JUDGE HAROLD HULS}

T621

\begin{tabular}{|c|c|c|}
\hline Nominee & Relationship & Characterization \\
\hline Milton J. Seidel & $\begin{array}{l}\text { "Oh, I think I have known } \\
\text { him } 20 \text { or } 25 \text { years. .. Well, } \\
\text { I have known him as a very } \\
\text { fine citizen. He was also a } \\
\text { member of my lodge, and } \\
\text { Masonic organizations, and } \\
\text { we have worked together in } \\
\text { that work, and I have known } \\
\text { him and his wife both quite } \\
\text { well." T622 }\end{array}$ & $\begin{array}{l}\text { Church. Civic Org., or } \\
\text { Club }\end{array}$ \\
\hline $\begin{array}{l}\text { Russell F. Thompson } \\
1959\end{array}$ & $\begin{array}{l}\text { "I think he was } \\
\text { recommended to me by } \\
\text { someone, and I had talked } \\
\text { with him before I-as I } \\
\text { always did with each } \\
\text { nominee that I made } \\
\text { nomination for." T624 }\end{array}$ & Recommended \\
\hline Carl Fennema & $\begin{array}{l}\text { "I first knew him when I was } \\
\text { on the California Public } \\
\text { Utilities Commission many } \\
\text { years ago, and we had an } \\
\text { outing at Catalina, and we got } \\
\text { to be friends on the boat, and } \\
\text { after, thereafter visited back } \\
\text { and forth. He came to my } \\
\text { office occasionally, and he } \\
\text { appeared to be a man of rare } \\
\text { intelligence and a truthful, } \\
\text { fine gentleman, and that is } \\
\text { the reason I nominated him." } \\
\text { T624 }\end{array}$ & $\begin{array}{c}\text { Friend; } \\
\text { Business Acquaintance }\end{array}$ \\
\hline
\end{tabular}




\begin{tabular}{|c|l|c|}
\hline Nominee & \multicolumn{1}{|c|}{ Relationship } & Characterization \\
\hline Louis Morris & $\begin{array}{l}\text { "I haven't seen him for years. } \\
\text { He used to be with Pacific } \\
\text { Telephone Company in } \\
\text { Pasadena. He was the branch } \\
\text { manager there. . . [He has } \\
\text { been a friend for] more than } \\
\text { 10 years, I'd say." T624-25 }\end{array}$ & Friend \\
\hline Roger Bone & A friend. T625 & \\
\hline Arnold Eddy & A friend. T626 & Friend \\
\hline Roy Anderson & $\begin{array}{l}\text { A friend. "I knew him very } \\
\text { well." T626 }\end{array}$ & Friend \\
\hline Joe Beranek & $\begin{array}{l}\text { A friend. T626 } \\
\text { William Welch }\end{array}$ & $\begin{array}{l}\text { "He was an insurance broker } \\
\text { [in Pasadena], and a friend of } \\
\text { mine, a long-term friend of } \\
\text { mine." T626 }\end{array}$ \\
\hline
\end{tabular}

JUDGE AUBREY N. IRWIN T486

\begin{tabular}{|c|c|c|}
\hline Nominee & Relationship & Characterization \\
\hline Carol W. Parcher & $\begin{array}{l}\text { "I have known him } \\
\text { approximately } 40 \text { years, more } \\
\text { or less. I went to Glendale in } \\
1927 \text {, and he was rather } \\
\text { prominent in that area about } \\
\text { that time, and I have known } \\
\text { him almost since that time." } \\
\text { T488 }\end{array}$ & Friend \\
\hline William J. Goss & $\begin{array}{l}\text { "I have known him since } \\
\text { about } 1928 \text {, and I have } \\
\text { known him as a businessman, } \\
\text { former client, and former } \\
\text { mayor of the City of } \\
\text { Glendale; a close, personal } \\
\text { friend, very fine man." T489 }\end{array}$ & $\begin{array}{c}\text { Friend; } \\
\text { Business Acquaintance }\end{array}$ \\
\hline Pauline Bunch & $\begin{array}{l}\text { "I have known her as a } \\
\text { neighbor, and a community } \\
\text { worker in the area in which I } \\
\text { live, a friend." T489 }\end{array}$ & $\begin{array}{l}\text { Friend: } \\
\text { Neighbor }\end{array}$ \\
\hline Roland F. Bush & $\begin{array}{l}\text { "[I have known him for } \\
\text { a]pproximately } 32 \text { years, and } \\
\text { I first became acquainted } \\
\text { with him when he was a vice- } \\
\text { president and general } \\
\text { manager of the Security First } \\
\text { National Bank in Glendale, } \\
\text { and I knew him as a banker, } \\
\text { and since then I know him as } \\
\text { a neighbor. He is now retired. } \\
\text { A friend." T489 }\end{array}$ & $\begin{array}{c}\text { Friend; } \\
\text { Business Acquaintance: } \\
\text { Neighbor }\end{array}$ \\
\hline
\end{tabular}




\begin{tabular}{|c|l|c|}
\hline Nominee : & \multicolumn{1}{|c|}{ Relationship } & Characterization \\
\hline Eugene F. French & $\begin{array}{l}\text { "I have known Mr. French } \\
\text { about 10 years, more or less. } \\
\text { I know him as an executive } \\
\text { of an insurance company, } \\
\text { Fireman's Fund Insurance } \\
\text { Company, and a citizen of the } \\
\text { area in which I reside. I know } \\
\text { him as a retired } \\
\text { gentleman ... a casual friend, } \\
\text { not too close." T489-90 }\end{array}$ & Business Acquaintance \\
\hline Bernard Anawalt & $\begin{array}{l}\text { "I have known him as a } \\
\text { former client, as a } \\
\text { businessman in our } \\
\text { community, semiretired at the } \\
\text { present time; a close personal } \\
\text { friend. ... II have known him } \\
\text { for] 23 years." T490 }\end{array}$ & \\
\hline
\end{tabular}

JUDGE BERNARD S. JEFFERSON T464

\begin{tabular}{|c|c|c|}
\hline Nominiee & Relationship & Characterization \\
\hline $\begin{array}{c}\text { Gano Culwell } \\
1961\end{array}$ & $\begin{array}{l}\text { "My recollection is that he } \\
\text { served on the board of } \\
\text { directors of the Los Angeles } \\
\text { Urban League, I believe. ... } \\
\text { [I knew him] probably five or } \\
\text { six years [before nominating } \\
\text { him]." T466 }\end{array}$ & $\begin{array}{l}\text { Church, Civic Org., or } \\
\text { Club }\end{array}$ \\
\hline Lola L. Beavers & $\begin{array}{l}\text { "[I have known her for] } \\
\text { many, many years. Mrs. } \\
\text { Beavers is the wife of George } \\
\text { Beavers, who is an officer of } \\
\text { the Golden State Mutual Life } \\
\text { Insurance Company.... My } \\
\text { acquaintance with the } \\
\text { Beavers has been both in } \\
\text { civic work and to a lesser } \\
\text { extent social." T466-67 }\end{array}$ & $\begin{array}{c}\text { Church, Civic Org., or } \\
\text { Club }\end{array}$ \\
\hline $\begin{array}{c}\text { Ophelia W. Bolger } \\
1962\end{array}$ & $\begin{array}{l}\text { "My recollection is ... } \\
\text { that ... she also was a lay } \\
\text { person, as we call it, working } \\
\text { in various capacities with the } \\
\text { Los Angeles Urban League." } \\
\text { T467 }\end{array}$ & $\begin{array}{l}\text { Church, Civic Org., or } \\
\text { Club }\end{array}$ \\
\hline $\begin{array}{c}\text { George Sevelle } \\
1962\end{array}$ & $\begin{array}{l}\text { "I knew him through the } \\
\text { Urban League, and also as a } \\
\text { businessman." T468 }\end{array}$ & $\begin{array}{l}\text { Church. Civic Org., or } \\
\text { Club; } \\
\text { Business Acquaintance }\end{array}$ \\
\hline Arthur J. Clement, Jr. & $\begin{array}{l}\text { "My recollection of him is } \\
\text { that he was a manager of ... } \\
\text { the North Carolina Mutual } \\
\text { Life Insurance Company." } \\
\text { T468 }\end{array}$ & Business Acquaintance \\
\hline
\end{tabular}




\begin{tabular}{|c|l|c|}
\hline Nominee & \multicolumn{1}{|c|}{ Relationship } & \multicolumn{1}{c|}{ Characterization } \\
\hline Helen G. Smith & $\begin{array}{l}\text { "[I have known her for] a } \\
\text { number a years. She is the } \\
\text { wife of now Judge Sherman } \\
\text { Smith, who is a Judge of the } \\
\text { Superior Court." T468-69 }\end{array}$ & Spouse of Acquaintance \\
\hline Ella K. Mays & $\begin{array}{l}\text { "[I have known her a]s a } \\
\text { friend, since approximately } \\
\text { 1948 or 49." T469 }\end{array}$ & Friend \\
\hline Benjamin Labiner & $\begin{array}{l}\text { "He, I think, was a friend, or } \\
\text { 1968 least a neighbor of my } \\
\text { brother Justice Edwin L. } \\
\text { Jefferson, and he } \\
\text { recommended Mr. Labiner to } \\
\text { me." T469-70 }\end{array}$ & Recommended \\
\hline
\end{tabular}

\section{JUDGE SIDNEY W. KAUFMAN} $\mathrm{T} 447$

\begin{tabular}{|c|l|c|}
\hline Nominee & \multicolumn{1}{|c|}{ Relationship } & Characterization \\
\hline Daniel S. Levine & $\begin{array}{l}\text { "[I have known him for] over } \\
\text { 20 years as a close friend, } \\
\text { primarily." T449 }\end{array}$ & Friend \\
\hline $\begin{array}{c}\text { Rosemary Halloman } \\
1964\end{array}$ & $\begin{array}{l}\text { "I met her I think only once. } \\
\text { I nominated her at the request } \\
\text { of another Judge who had } \\
\text { filled his nomination, and } \\
\text { who had assured me of her } \\
\text { qualifications." T449 }\end{array}$ & Recommended \\
\hline Albert L. Leveton & $\begin{array}{l}\text { "Well, he's been a warm and } \\
\text { intimate friend for many, } \\
\text { many years." T450 }\end{array}$ & Friend \\
\hline Boris Frankel & $\begin{array}{l}\text { "[I have known him for] } \\
\text { several years, as a friend; and } \\
\text { I play a lot of bridge with } \\
\text { him, or did." T451 }\end{array}$ & Friend \\
\hline
\end{tabular}

JUDGE WILLIAM B. KEENE $\mathrm{T} 755$

\begin{tabular}{|c|l|c|}
\hline Nominee & \multicolumn{1}{|c|}{ Relationship } & \multicolumn{1}{|c|}{ Characterization } \\
\hline Oral Dryden & $\begin{array}{l}\text { "Well, Dryden was a former } \\
\text { partner of mine, and Oral } \\
\text { Dryden-my wife and I have } \\
\text { known Oral Dryden for 10 } \\
\text { years." T756 }\end{array}$ & Business Acquaintance \\
\hline Eileen Brown & $\begin{array}{l}\text { "Eileen Brown is a neighbor } \\
\text { and personal friend, and I } \\
\text { have known her for } \\
\text { approximately 10 years." } \\
\text { T756 }\end{array}$ & \multicolumn{1}{|c|}{ Friend; } \\
\hline
\end{tabular}




\begin{tabular}{|c|l|c|}
\hline Nominee & \multicolumn{1}{|c|}{ Relationship } & Characterization \\
\hline Mebs McKay Peterson & "I have known her for & Recommended \\
& approximately one year, and & \\
& she is a friend of a friend.... & \\
& She was recommended to & \\
& me... [by a] Deputy District & \\
& Attomey.... T756-57 & \\
\hline
\end{tabular}

\section{JUDGE BEN KOENIG} T497

\begin{tabular}{|c|c|c|}
\hline Nominee & Relationship & Characterization \\
\hline Theodore R. Ellsworth & $\begin{array}{l}\text { "I have known Mr. Ellsworth } \\
\text { at least since-I think it was } \\
\text { the late } 1930 \text { s, and he was the } \\
\text { business manager for the } \\
\text { Wardrobe Union of the } \\
\text { motion picture industry, and } \\
\text { now is a professor at } \\
\text { UCLA." A friend. T498-99 }\end{array}$ & Friend \\
\hline Albert Levinson & $\begin{array}{l}\text { "I have known Mr. Levinson } \\
\text { for about } 15 \text { years. He is the } \\
\text { president of the General Pipe } \\
\& \text { Supply Company at } \\
\text { Compton. He is a very } \\
\text { personal friend of mine." } \\
\text { T499 }\end{array}$ & Friend \\
\hline Willard Isaacs & $\begin{array}{l}\text { "I have known him about } 25 \\
\text { or } 30 \text { years.... He was a } \\
\text { client of mine. He was } \\
\text { associated with the Westmore } \\
\text { Cosmetics and Salon." A } \\
\text { friend. T499 }\end{array}$ & $\begin{array}{c}\text { Friend; } \\
\text { Business Acquaintance }\end{array}$ \\
\hline Abner Parker & $\begin{array}{l}\text { "I have known Mr. Parker } \\
\text { almost } 40 \text { years. .. I met } \\
\text { him when I lived in } \\
\text { Milwaukee, Wisconsin. He } \\
\text { was then a resident of } \\
\text { Chicago." A friend. T500 }\end{array}$ & Friend \\
\hline Jack J. Bayer & $\begin{array}{l}\text { "I have known Mr. Bayer for } \\
\text { approximately } 10 \text { or } 12 \text { years. } \\
\text { My association with Mr. } \\
\text { Bayer was in charity work for } \\
\text { the Jewish Home for the } \\
\text { Aged. He was the vice- } \\
\text { president." A friend. T500 }\end{array}$ & $\begin{array}{c}\text { Friend; } \\
\text { Church, Civic Org., or } \\
\text { Club }\end{array}$ \\
\hline Alvin A. Lavine & $\begin{array}{l}\text { "Mr. Lavine was-at the } \\
\text { present time is a member of } \\
\text { the Grand Jury, and my } \\
\text { nominee. I have known him } \\
\text { for, oh, more than } 10 \text { years." } \\
\text { A friend. T500-01 }\end{array}$ & Friend \\
\hline
\end{tabular}


JUDGE BENJAMIN LANDIS T600

\begin{tabular}{|c|c|c|}
\hline Nominee & Relationship & Characterization \\
\hline $\begin{array}{c}\text { Rosalie Hutton } \\
1961\end{array}$ & $\begin{array}{l}\text { "Well, I'm only guessing } \\
\text { now. I wouldn't consider her } \\
\text { an intimate friend of mine, } \\
\text { but I have known her several } \\
\text { years, about several years, } \\
\text { yes." T602 }\end{array}$ & Friend \\
\hline $\begin{array}{c}\text { Maurice R. Schez } \\
1966\end{array}$ & $\begin{array}{l}\text { "I have known him over } 20 \\
\text { years socially, and he is a } \\
\text { very good friend of mine. He } \\
\text { was former vice-president of } \\
\text { Max Factor Company." T603 }\end{array}$ & Friend \\
\hline Gretchen Stanbury & $\begin{array}{l}\text { "I have known her about } 15 \\
\text { years. She is a widow now, } \\
\text { but Raymond Stanbury was a } \\
\text { very prominent trial lawyer." } \\
\text { T603 }\end{array}$ & Friend \\
\hline Carl Titelman & $\begin{array}{l}\text { "[I have known him for] } \\
\text { perhaps a decade } \\
\text { [socially].... He was-had a } \\
\text { chain of markets, and then he } \\
\text { sold them and retired." T603 }\end{array}$ & Friend \\
\hline Samuel Bischoff & $\begin{array}{l}\text { "Very well. He is a very } \\
\text { prominent motion picture } \\
\text { producer. I have known him } \\
\text { for } 25 \text { years." T } 603\end{array}$ & Friend \\
\hline Milton Berancik & $\begin{array}{l}\text { "Well, I've known him } \\
\text { socially for } 20 \text { years or more. } \\
\text { He is a member of my } \\
\text { country club, and we have } \\
\text { been good friends for many } \\
\text { years." T604 }\end{array}$ & $\begin{array}{c}\text { Friend; } \\
\text { Church, Civic Org., or } \\
\text { Club }\end{array}$ \\
\hline
\end{tabular}

JUDGE WILLIAM H. LEVIT T580

\begin{tabular}{|c|l|c|}
\hline Nominee & \multicolumn{1}{|c|}{ Relationship } & \multicolumn{1}{|c|}{ Characterization } \\
\hline Desmond Moody & "I'd say [I have known him] & Business Acquaintance \\
& in excess of 20 years. ... & \\
& Well, I knew him in business & \\
& when I practiced law. I think & \\
& he has been at my house and I & \\
& have been at his house. I & \\
& wouldn't say that we are & \\
& intimate social friends, \\
& anything like that, but I know & \\
& him." T583 \\
\hline
\end{tabular}




\begin{tabular}{|c|c|c|}
\hline Nominee & Relationship & Characterization \\
\hline Helen Rice & $\begin{array}{l}\text { "Well, I've known Mrs. Rice, } \\
\text { I would say, } 40 \text { years, } \\
\text { approximately... I I knew } \\
\text { her when she was quite } \\
\text { young, when I grew up in San } \\
\text { Francisco, when I first met } \\
\text { her. I know her husband. My } \\
\text { wife knows her, knows her } \\
\text { husband. We see each other } \\
\text { from time to time over the } \\
\text { years. I would say that } \\
\text { although there has been some } \\
\text { business relationship, } \\
\text { basically our relationship was } \\
\text { a social relation." T584 }\end{array}$ & $\begin{array}{c}\text { Friend; } \\
\text { Business Acquaintance }\end{array}$ \\
\hline Jane Sinn & $\begin{array}{l}\text { "We were neighbors for a } \\
\text { period of time. I have had a- } \\
\text { also when I practiced law, I } \\
\text { had a business relationship } \\
\text { with her husband, and to } \\
\text { some extent with her." T585 }\end{array}$ & $\begin{array}{c}\text { Business Acquaintance; } \\
\text { Spouse of Acquaintance; } \\
\text { Neighbor }\end{array}$ \\
\hline Ruth Meyer & $\begin{array}{l}\text { "Basically she and her } \\
\text { husband are social friends. I } \\
\text { have also had some slight } \\
\text { business connection, I would } \\
\text { say, with her family, when I } \\
\text { practiced law... . [I have } \\
\text { known her] in excess of } 20 \\
\text { years." T585 }\end{array}$ & Friend \\
\hline Jane Ilfeld & $\begin{array}{l}\text { "I'd say basically a social } \\
\text { relationship. However, she } \\
\text { has been active in community } \\
\text { affairs, and I'm sure that I } \\
\text { have had some dealings with } \\
\text { her in that capacity, and her } \\
\text { husband is a doctor. I have } \\
\text { had-I've been a patient of } \\
\text { her husband on occasion." } \\
\text { T585 }\end{array}$ & Friend \\
\hline Lawrence Welling & $\begin{array}{l}\text { "I'd say socially. I'm also } \\
\text { acquainted with the business } \\
\text { he was connected with at one } \\
\text { time. I believe he is retired, } \\
\text { but I had no business } \\
\text { relationship with him } \\
\text { individually." T586 }\end{array}$ & Friend \\
\hline Ann Neisser & $\begin{array}{l}\text { "I know her socially, and her } \\
\text { family. I have had some } \\
\text { business relationship with her } \\
\text { husband. ... [I have known } \\
\text { her i]n excess of } 20 \text { years." } \\
\text { T586 }\end{array}$ & $\begin{array}{c}\text { Friend: } \\
\text { Spouse of Acquaintance }\end{array}$ \\
\hline
\end{tabular}


JUDGE ARTHUR K. MARSHALL T879

\begin{tabular}{|c|c|c|}
\hline Nominee & Relationship & Characterization \\
\hline Verna M. McTavish & $\begin{array}{l}\text { "[I have known her for } \\
\text { p]robably about five or six } \\
\text { years. . . She is the wife, or } \\
\text { the widow, of a lawyer." } \\
\text { T881 }\end{array}$ & Spouse of Acquaintance \\
\hline Sam Sarkisian & $\begin{array}{l}\text { "[I have known him for } \\
\text { about }] \text { five of six years.... } \\
\text { He was a member of an } \\
\text { organization to which I } \\
\text { belonged. ... The Town Club } \\
\text { of Santa Monica." T881 }\end{array}$ & $\begin{array}{l}\text { Church, Civic Org., or } \\
\text { Club }\end{array}$ \\
\hline $\begin{array}{l}\text { Hortense D. Fishbaugh } \\
\text { (nominated three times) }\end{array}$ & $\begin{array}{l}\text { "[I knew her for] about three } \\
\text { years [before nominating } \\
\text { her]. ... She was a friend of } \\
\text { my wife's." T881-82 }\end{array}$ & Friend \\
\hline John Carlton Bennett & $\begin{array}{l}\text { "He was recommended to } \\
\text { me. I didn't know him } \\
\text { personally." T882 }\end{array}$ & Recommended \\
\hline George A. Carter & $\begin{array}{l}\text { "He was a friend; I would } \\
\text { say more an acquaintance } \\
\text { than a friend, a close } \\
\text { acquaintance." T882 }\end{array}$ & Friend \\
\hline
\end{tabular}

Judge William B. NEELEY T781

\begin{tabular}{|c|c|c|}
\hline Nominee & Relationship & Characterization \\
\hline Wilma Imm & $\begin{array}{l}\text { "I believe [I met her] in } \\
\text { connection with one of the } \\
\text { community organizations in } \\
\text { Glendale, but I have been } \\
\text { president of practically all of } \\
\text { those organizations at one } \\
\text { time or another, and I have } \\
\text { worked with these } \\
\text { people... . Yes, she was [a } \\
\text { personal friend]." T782 }\end{array}$ & $\begin{array}{c}\text { Friend; } \\
\text { Church. Civic Org., or } \\
\text { Club }\end{array}$ \\
\hline Irma Corbett & $\begin{array}{l}\text { "I think her husband was the } \\
\text { famous jockey, and they were } \\
\text { interested in Chevy Chase } \\
\text { Country Club and active in } \\
\text { Glendale. .. I got to know } \\
\text { her through maybe my wife's } \\
\text { activities with the Tuesday } \\
\text { Club, and social engagements } \\
\text { through that." T783 }\end{array}$ & $\begin{array}{l}\text { Church, Civic Org., or } \\
\text { Club }\end{array}$ \\
\hline Ralph Robison & $\begin{array}{l}\text { "[H]e was-used to be head } \\
\text { of Streets and Parks, or } \\
\text { something, in the City of } \\
\text { Glendale, and I nominated } \\
\text { him after he retired. ... I had } \\
\text { known him, oh, let's say } 25 \\
\text { years." T784 }\end{array}$ & Friend \\
\hline
\end{tabular}




\begin{tabular}{|c|c|c|}
\hline Nominee & Relationship & Characterization \\
\hline Audrey Small & $\begin{array}{l}\text { "[W]e have always had her in } \\
\text { and among our social group, } \\
\text { and I have probably known } \\
\text { her } 20 \text { or } 25 \text { years. She will } \\
\text { be a guest in my home in } \\
\text { about two weeks." T784 }\end{array}$ & Friend \\
\hline Dorothy Brewster & $\begin{array}{l}\text { "I didn't know Mrs. Brewster } \\
\text { as well, but I got acquainted } \\
\text { with her through one of these } \\
\text { Community Concers, or } \\
\text { Glendale Symphony } \\
\text { Orchestra, and I worked with } \\
\text { her there, but she has not } \\
\text { been as much of a family } \\
\text { friend as these others have } \\
\text { been." T784 }\end{array}$ & $\begin{array}{c}\text { Church, Civic Org.. or } \\
\text { Club }\end{array}$ \\
\hline Frances Doll & $\begin{array}{l}\text { "Her husband is in the } \\
\text { electrical business in } \\
\text { Glendale. She was another } \\
\text { one that I became well- } \\
\text { acquainted with in connection } \\
\text { with Community Concen } \\
\text { activities. She lives about five } \\
\text { blocks from us." T785 }\end{array}$ & $\begin{array}{c}\text { Church. Civic Org., or } \\
\text { Club; } \\
\text { Neighbor }\end{array}$ \\
\hline Essie Hunter & $\begin{array}{l}\text { "Well, I think I have } \\
\text { probably known her, before } \\
\text { her nomination, probably } 15 \\
\text { years. ... She is a member of } \\
\text { the County Music } \\
\text { Commission, active in } \\
\text { Community Orchestra affairs, } \\
\text { and I was on the County } \\
\text { Music Commission, president } \\
\text { of the Glendale } \\
\text { Symphony.... T785 }\end{array}$ & $\begin{array}{c}\text { Church, Civic Org., or } \\
\text { Club }\end{array}$ \\
\hline Hilma Treidler & $\begin{array}{l}\text { "Mrs. Treidler was known to } \\
\text { me again through Community } \\
\text { Concerts, her work there." } \\
\text { T785-86 }\end{array}$ & $\begin{array}{l}\text { Church, Civic Org., or } \\
\text { Club }\end{array}$ \\
\hline Marjorie Noble & $\begin{array}{l}\text { "Mrs. Noble was a member } \\
\text { of our church group, to which } \\
\text { I belonged, and I knew } \\
\text { her .. I think I knew her } \\
\text { primarily through Charity } \\
\text { League." T786 }\end{array}$ & $\begin{array}{l}\text { Church, Civic Org., or } \\
\text { Club }\end{array}$ \\
\hline Helen Erickson & $\begin{array}{l}\text { "Mrs. Erickson is very active } \\
\text { in my church, which is the } \\
\text { First Methodist Church of } \\
\text { Glendale... . She is also, and } \\
\text { her husband, are friends of } \\
\text { the family, and we have } \\
\text { family friendships together." } \\
\text { T786 }\end{array}$ & $\begin{array}{c}\text { Friend; } \\
\text { Church. Civic Org., or } \\
\text { Club }\end{array}$ \\
\hline
\end{tabular}




\begin{tabular}{|c|c|c|}
\hline Nominee & Relationship & Characterization \\
\hline Mary Fessenden & $\begin{array}{l}\text { "She is also a lady whom I } \\
\text { became acquainted with } \\
\text { through the church. She } \\
\text { doesn't belong to our church, } \\
\text { but she is a soloist at the } \\
\text { Pasadena Methodist Church, } \\
\text { and I got acquainted with her } \\
\text { through Mrs. Erickson." } \\
\text { T786-87 }\end{array}$ & $\begin{array}{l}\text { Church, Civic Org., or } \\
\text { Club }\end{array}$ \\
\hline Eric House & $\begin{array}{l}\text { "Mr. House is a retired } \\
\text { engineer. I first met him at a } \\
\text { dinner at the Erickson's, and } \\
\text { he had just retired at that } \\
\text { time. I had probably known } \\
\text { him as little as any one } \\
\text { person I ever nominated to } \\
\text { the Grand Jury, but my } \\
\text { conversations with him, his } \\
\text { background and experience } \\
\text { and so on and his availability, } \\
\text { caused me to nominate him." } \\
\text { T787 }\end{array}$ & Uncharacterized \\
\hline
\end{tabular}

JUDGE H. BURTON NOBLE $\mathrm{T} 743$

\begin{tabular}{|c|c|c|}
\hline Nominee & Relationship & Characterization \\
\hline Elmer Wilson & $\begin{array}{l}\text { "[I have known him for] } 30 \\
\text { years ... [a]s a social } \\
\text { acquaintance. . . I do } \\
\text { business with him." T744-45 }\end{array}$ & $\begin{array}{c}\text { Friend; } \\
\text { Business Acquaintance }\end{array}$ \\
\hline John Davidson & $\begin{array}{l}\text { "[I have known him for] } 30 \\
\text { years ... [as a s]ocial } \\
\text { [acquaintance], and when he } \\
\text { was in business, I did } \\
\text { business with him." Member } \\
\text { of Kiwanis Club. T745-46 }\end{array}$ & $\begin{array}{c}\text { Friend: } \\
\text { Church, Civic Org., or } \\
\text { Club; } \\
\text { Business Acquaintance }\end{array}$ \\
\hline John H. Bigger & $\begin{array}{l}\text { Knew hin for same time and } \\
\text { in same capacity as John } \\
\text { Davidson. Member of } \\
\text { Kiwanis Club. T745-46 }\end{array}$ & $\begin{array}{c}\text { Friend: } \\
\text { Church, Civic Org., or } \\
\text { Club; } \\
\text { Business Acquaintance }\end{array}$ \\
\hline John Sample & $\begin{array}{l}\text { "[I have known him for }] 15 \\
\text { years or more, and as a social } \\
\text { acquaintance." T745 }\end{array}$ & Friend \\
\hline Verne Orr & $\begin{array}{l}\text { "Social acquaintance, and a } \\
\text { number of these that you are } \\
\text { mentioning belong to the } \\
\text { same service club [Kiwanis } \\
\text { Club] I belong to, did belong } \\
\text { to." T745-46 }\end{array}$ & $\begin{array}{l}\text { Friend; } \\
\text { Church, Civic Org., or } \\
\text { Club }\end{array}$ \\
\hline
\end{tabular}




\begin{tabular}{|c|l|c|}
\hline Nominee & \multicolumn{1}{|c|}{ Relationship } & \multicolumn{1}{|c|}{ Characterizalion } \\
\hline Donald La Motte & $\begin{array}{l}\text { "[I knew him for] 20 years, I } \\
\text { would say, 15 or 20 years. } \\
\text { and he was manager of the } \\
\text { Sears store in Pasadena. I } \\
\text { knew him in that capacity." } \\
\text { T747-48 }\end{array}$ & Business Acquaintance \\
\hline James P. Morgan & $\begin{array}{l}\text { "He was recommended to } \\
\text { me. I am not acquainted with } \\
\text { him. . . I think it was Judge } \\
\text { Newell, an ex-member of this } \\
\text { Court, but I am not real sure, } \\
\text { but he was highly } \\
\text { recommended, and I } \\
\text { nominated him on that } \\
\text { basis." T747 }\end{array}$ & \\
\hline
\end{tabular}

JUDGE RALPH H. NUTTER T683

\begin{tabular}{|c|c|c|}
\hline Nominee & Relationship & Characterization \\
\hline Betty V. Harvey & $\begin{array}{l}\text { "She was a next-door } \\
\text { neighbor when I lived in } \\
\text { Altadena for many years." } \\
\text { T684 }\end{array}$ & Neighbor \\
\hline Gladys Smith & $\begin{array}{l}\text { "I knew Mrs. Smith since } \\
\text { 1948. She was the wife of my } \\
\text { former law partner." A } \\
\text { friend. T685 }\end{array}$ & $\begin{array}{c}\text { Friend; } \\
\text { Spouse of Acquaintance }\end{array}$ \\
\hline Everett Franklin & $\begin{array}{l}\text { "Mr. Franklin was the } \\
\text { international representative of } \\
\text { the United Automobile } \\
\text { Workers, a Negro, and a } \\
\text { member of the United Civil } \\
\text { Rights Congress... I knew } \\
\text { him both professionally and } \\
\text { socially [since 1948]." T685- } \\
86\end{array}$ & $\begin{array}{l}\text { Friend; } \\
\text { Church. Civic Org., or } \\
\text { Club }\end{array}$ \\
\hline Helen Schwartz & $\begin{array}{l}\text { "She was the wife of a } \\
\text { lawyer who took my place } \\
\text { when I went on the bench. [I } \\
\text { have known her slince about } \\
\text { 1959, I think. I knew her } \\
\text { husband many years before } \\
\text { that." T686 }\end{array}$ & Spouse of Acquaintance \\
\hline Eloise Davis & $\begin{array}{l}\text { "My recollection is, I may be } \\
\text { wrong in this, I think she was } \\
\text { a minority group, a Negro } \\
\text { who was recommended to me } \\
\text { by someone else, [who] was } \\
\text { trying to get minority group } \\
\text { representation on the Grand } \\
\text { Jury.... I think it may have } \\
\text { been a Judge." T686-87 }\end{array}$ & Recommended \\
\hline
\end{tabular}




\begin{tabular}{|c|l|c|}
\hline Nominee & \multicolumn{1}{|c|}{ Relationship } & Characterization \\
\hline Ann Kennedy & $\begin{array}{l}\text { "I knew her as a personal } \\
\text { friend when I lived in } \\
\text { Altadena, since about '49, } \\
\text { and I still know her socially." } \\
\text { T688 }\end{array}$ & Friend \\
\hline Margaret Lloyd & $\begin{array}{l}\text { "I have known her since } \\
\text { about six or seven years } \\
\text { socially." T688 }\end{array}$ & Friend \\
\hline Mavis Fehr & $\begin{array}{l}\text { "I think I have known her } \\
\text { since about 1957 or'58. She } \\
\text { is a neighbor where I live } \\
\text { presently. She lives about a } \\
\text { mile from me." T688 }\end{array}$ & Neighbor \\
\hline
\end{tabular}

\section{JUDGE BAYARD RHONE}

T659

\begin{tabular}{|c|c|c|}
\hline Nominee & Relationship & Characterization \\
\hline Grant Goodale & $\begin{array}{l}\text { "Oh, I have known him for } \\
30 \text { years, I guess. ... A } \\
\text { business acquaintance, friend, } \\
\text { socially." T661 }\end{array}$ & $\begin{array}{c}\text { Friend; } \\
\text { Business Acquaintance }\end{array}$ \\
\hline $\begin{array}{c}\text { Ruth Stransky } \\
1958\end{array}$ & $\begin{array}{l}\text { "[I have known her] I } \\
\text { suppose } 10 \text { or } 12 \text { years, } \\
\text { neighbor." A friend. T661 }\end{array}$ & $\begin{array}{l}\text { Friend; } \\
\text { Neighbor }\end{array}$ \\
\hline Colonel K. Charles Bean & $\begin{array}{l}\text { "Well, I guess I have known } \\
\text { him about } 25 \text { years, and I } \\
\text { have met him through the } \\
\text { church association." T662 }\end{array}$ & $\begin{array}{c}\text { Church, Civic Org., or } \\
\text { Club }\end{array}$ \\
\hline Kenneth Payne & $\begin{array}{l}\text { "Oh, [I have known him] } \\
\text { probably } 15 \text { years, and I met } \\
\text { him also through the } \\
\text { church." T662 }\end{array}$ & $\begin{array}{l}\text { Church, Civic Org., or } \\
\text { Club }\end{array}$ \\
\hline Charles Fuller & $\begin{array}{l}\text { "[I have known him } \\
\text { p]robably } 30 \text { years. I met } \\
\text { him, he was the director of- } \\
\text { or the head of the Department } \\
\text { of Weights and Measures of } \\
\text { the County, and I became } \\
\text { acquainted with him when I } \\
\text { was a Deputy Attorney } \\
\text { General, State of } \\
\text { California... . [W] } \\
\text { eventually became very } \\
\text { friendly." T662 }\end{array}$ & $\begin{array}{c}\text { Friend; } \\
\text { Business Acquaintance }\end{array}$ \\
\hline Harold Dryden & $\begin{array}{l}\text { "[I have known him for } \\
\text { a]bout eight or nine } \\
\text { years... . I met him through } \\
\text { various Camellia societies } \\
\text { that he belongs to and that I } \\
\text { belong to.... He is now [a } \\
\text { friend]." T663 }\end{array}$ & $\begin{array}{c}\text { Friend; } \\
\text { Church, Civic Org., or } \\
\text { Club }\end{array}$ \\
\hline Albert Dekker & $\begin{array}{l}\text { "The same as Mr. Dryden." } \\
\text { T663 }\end{array}$ & $\begin{array}{l}\text { Friend: } \\
\text { Church, Civic Org., or } \\
\text { Club }\end{array}$ \\
\hline
\end{tabular}




\begin{tabular}{|c|c|c|}
\hline Nominee & Relationship & Characterization \\
\hline Elmer Struebing & $\begin{array}{l}\text { "Oh, I've known him } \\
\text { probably } 20 \text { years. I got } \\
\text { acquainted with him through } \\
\text { his children and my children } \\
\text { when they were going to L.A. } \\
\text { High, and Pomona } \\
\text { College... He was la } \\
\text { friend]." T663-64 }\end{array}$ & Friend \\
\hline Raymond Abernathy & $\begin{array}{l}\text { "He was [a friend and], I } \\
\text { think, chief toxicologist of } \\
\text { the Coroner's Office, and I } \\
\text { had met him through the-- } \\
\text { my work in the Attorney } \\
\text { General's Office." T664 }\end{array}$ & $\begin{array}{c}\text { Friend; } \\
\text { Business Acquaintance }\end{array}$ \\
\hline Philip Couturier & $\begin{array}{l}\text { "I met him, I think, in } \\
1952 . . . \text { He was a member } \\
\text { of my Masonic Lodge." } \\
\text { T664 }\end{array}$ & $\begin{array}{l}\text { Church, Civic Org., or } \\
\text { Club }\end{array}$ \\
\hline Avery Munger & $\begin{array}{l}\text { "I think I got acquainted with } \\
\text { him through our children in } \\
\text { Sunday school, and they must } \\
\text { have been about eight or nine } \\
\text { then, and that would make it } \\
\text { about } 20 \text { years ago." T665 }\end{array}$ & $\begin{array}{l}\text { Church, Civic Org., or } \\
\text { Club }\end{array}$ \\
\hline Jack Finch & $\begin{array}{l}\text { A friend for " } 10 \text { or } 15 \\
\text { years." T665 }\end{array}$ & Friend \\
\hline Ralph O. Chick & $\begin{array}{l}\text { "I became acquainted with } \\
\text { him I think at the time of the } \\
X \text { Olympic games in Los } \\
\text { Angeles in 1932. I was in the } \\
\text { Attorney General's Office, } \\
\text { and I think he had something } \\
\text { to do with the operation of } \\
\text { the Coliseum at the time. . . } \\
\text { He is also a member of my } \\
\text { Masonic Lodge, but he } \\
\text { doesn't attend very often." } \\
\text { T665-66 }\end{array}$ & $\begin{array}{l}\text { Church. Civic Org., or } \\
\text { Club; } \\
\text { Business Acquaintance }\end{array}$ \\
\hline William Coberly & $\begin{array}{l}\text { "I have known him about six } \\
\text { or seven years. He is a } \\
\text { member of the board of } \\
\text { trustees of my church." T666 }\end{array}$ & $\begin{array}{c}\text { Church, Civic Org., or } \\
\text { Club }\end{array}$ \\
\hline
\end{tabular}


JUDGE RAYMOND R. ROBERTS

T733

\begin{tabular}{|c|c|c|}
\hline Nominee & Relationship & Characterization \\
\hline Catherine Beachy & $\begin{array}{l}\text { "[She was recommended by] } \\
\text { several friends of mine." } \\
\text { T734 }\end{array}$ & Recommended \\
\hline Lucille Bernardi & $\begin{array}{l}\text { "[I have known her for] } 20 \\
\text { years, socially, politically, } \\
\text { economically. ... . Her } \\
\text { husband is a member of the } \\
\text { Los Angeles City } \\
\text { Council...." T735 }\end{array}$ & Friend \\
\hline $\begin{array}{c}\text { Veronica Dysart } \\
1967\end{array}$ & $\begin{array}{l}\text { "I have known her for about } \\
15 \text { years as a social } \\
\text { acquaintance." T735 }\end{array}$ & Friend \\
\hline $\begin{array}{c}\text { Eleanor Brown } \\
1968\end{array}$ & $\begin{array}{l}\text { "I made a canvass of all of } \\
\text { my friends and acquaintances } \\
\text { in public life to get people } \\
\text { nominated from minority, } \\
\text { ethnic, and geographical } \\
\text { areas. Either Councilman } \\
\text { Bradley or Councilman Mills } \\
\text { nominated her as a person } \\
\text { who was of the black race } \\
\text { and lived in the Watts area, } \\
\text { and on their } \\
\text { recommendations I } \\
\text { nominated her, because there } \\
\text { was a paucity of nominees } \\
\text { from that area." T736 }\end{array}$ & Recommended \\
\hline Dorothy Seifert & $\begin{array}{l}\text { "I have known her for } \\
\text { perhaps } 15 \text { years socially." } \\
\text { T736-37 }\end{array}$ & Friend \\
\hline
\end{tabular}

JUDGE EUGENE E. SAX T836

\begin{tabular}{|c|c|c|}
\hline Nominee & Relationship & Characterization \\
\hline Gertrude Burton & $\begin{array}{l}\text { "[She is my n]ext-door } \\
\text { neighbor. [I have known her } \\
\text { for a]bout } 10 \text { years." T837 }\end{array}$ & Neighbor \\
\hline Illeana Hamilton & $\begin{array}{l}\text { "[I know her a]s a friend and } \\
\text { as the wife of an attorney } \\
\text { whom I knew very well some } \\
\text { years ago. His name was } \\
\text { Fairfax Cosby, [and he] was a } \\
\text { City Attorney of Los } \\
\text { Angeles." T838 }\end{array}$ & $\begin{array}{c}\text { Friend; } \\
\text { Spouse of Acquaintance }\end{array}$ \\
\hline
\end{tabular}




\begin{tabular}{|c|l|c|}
\hline Nominee & \multicolumn{1}{|c|}{ Relationship } & \multicolumn{1}{|c|}{ Characterization } \\
\hline Otto Ferminger & $\begin{array}{l}\text { "[I have known him for] } \\
\text { about eight to ten years... } \\
\text { [o]n a business basis ... I } \\
\text { think he was the next to the } \\
\text { top position in a real estate } \\
\text { department in the Farmers \& } \\
\text { Merchants Bank, and I had } \\
\text { some real estate } \\
\text { transactions ... with the } \\
\text { bank, and he was the } \\
\text { gentleman with whom I had } \\
\text { to discuss most of that, and I } \\
\text { got to know him quite well." } \\
\text { T838-39 }\end{array}$ & \\
\hline Harry Levinsky & $\begin{array}{l}\text { "[I have known him for] } \\
\text { between six and eight years } \\
\text { [in a social capacity]." T839 }\end{array}$ & \\
\hline Ella Barnes & $\begin{array}{l}\text { "[I have known her for } \\
\text { a]bout 15 years [in a social } \\
\text { capacity], and also [as] a } \\
\text { former client when I was } \\
\text { practicing law." T839 }\end{array}$ & Business Acquaintance \\
\hline
\end{tabular}

JUDGE RICHARD SCHAUER T848

\begin{tabular}{|c|l|c|}
\hline Nominee & \multicolumn{1}{|c|}{ Relationship } & Characterization \\
\hline Dorothy Schoon & $\begin{array}{l}\text { "Oh, I knew her socially. She } \\
\text { was a friend of my wife's, } \\
\text { friend of mine, and her } \\
\text { family, her mother was a } \\
\text { friend of our families." T850 }\end{array}$ & Friend \\
\hline Estelle Masaryk & $\begin{array}{l}\text { "She is a friend of another } \\
\text { Judge whom I know, and I } \\
\text { had talked to her on a couple } \\
\text { of occasions. I don't know } \\
\text { her well." Recommended by } \\
\text { the other judge. T850 }\end{array}$ & Recommended \\
\hline Maureen McCormick & $\begin{array}{l}\text { "Oh, again over five years. } \\
\text { She and her family are } \\
\text { friends of our family." T851 }\end{array}$ & Friend \\
\hline Anita Chaikin & $\begin{array}{l}\text { "Oh, probably about five } \\
\text { years, and she and her } \\
\text { husband are friends of mine } \\
\text { and our family." T851 }\end{array}$ & Friend \\
\hline Charlotte Rothman & $\begin{array}{l}\text { "She is a friend of a friend of } \\
\text { mine." T851 }\end{array}$ & Uncharacterized \\
\hline
\end{tabular}


JUDGE HAROLD W. SCHWEITZER

T304

\begin{tabular}{|c|l|c|}
\hline Nominee & \multicolumn{1}{|c|}{ Relationship } & Characterization \\
\hline $\begin{array}{c}\text { Arthur Logan Spring } \\
\text { 1959 }\end{array}$ & $\begin{array}{l}\text { "He was a neighbor who } \\
\text { lived across the street." T307 }\end{array}$ & Neighbor \\
\hline $\begin{array}{c}\text { Kenneth A. Murray } \\
\text { 1959, 1960 }\end{array}$ & $\begin{array}{l}\text { "I have known him for 15 or } \\
\text { 20 years on a purely social } \\
\text { basis." T307 }\end{array}$ & Friend \\
\hline $\begin{array}{c}\text { Laverne Brown } \\
1960\end{array}$ & $\begin{array}{l}\text { Knew him on a "[s]ocial" } \\
\text { basis for "[a]bout 10 to 15 } \\
\text { years prior to" nominating } \\
\text { him. T307-08 }\end{array}$ & Friend \\
\hline Herman G. Lofgren & $\begin{array}{l}\text { Recommended by another } \\
\text { judge as "somebody that he } \\
\text { knew well." T308 }\end{array}$ & Recommended \\
1961 & $\begin{array}{l}\text { "I've known him through a } \\
\text { professional organization } \\
\text { since about 1946." T309 }\end{array}$ & $\begin{array}{c}\text { Church, Civic Org., or } \\
\text { Club }\end{array}$ \\
\hline George M. Scott & $\begin{array}{l}\text { "Through a professional } \\
\text { organization [the Kiwanis } \\
\text { Club], since about 1946." } \\
\text { T309 }\end{array}$ & $\begin{array}{c}\text { Church, Civic Org., or } \\
\text { Club }\end{array}$ \\
\hline
\end{tabular}

JUDGE BERNARD S. SELBER T769

\begin{tabular}{|c|l|c|}
\hline \multicolumn{1}{|c|}{ Nominee } & \multicolumn{1}{|c|}{ Relationship } & Characterization \\
\hline Barbara Turner Double & $\begin{array}{l}\text { "I guess I have known her for } \\
\text { approximately 10 years, and } \\
\text { as a personal friend." T771 }\end{array}$ & Friend \\
\hline Edward Kraus & $\begin{array}{l}\text { "I guess I have known Mr. } \\
\text { Kraus for better than 10 } \\
\text { years, and also as a personal } \\
\text { friend." T771 }\end{array}$ & Friend \\
\hline Stacey Williams & $\begin{array}{l}\text { "I never met her personally, } \\
\text { although I have in a sense } \\
\text { investigated her through } \\
\text { others. . . [She was } \\
\text { recommended by] } \\
\text { Councilman Thomas } \\
\text { Bradley." T771 }\end{array}$ & Recommended \\
\hline
\end{tabular}

JUDGE JOSEPH A. SPRANKLE T824

\begin{tabular}{|c|l|c|}
\hline Nominee & \multicolumn{1}{|c|}{ Relationship } & Characterization \\
\hline Betsy Farrand & $\begin{array}{l}\text { "[I have known her] as a } \\
\text { friend, family acquaintance, } \\
15 \text { to 20 years." T825 }\end{array}$ & Friend \\
\hline Elizabeth Hansen & $\begin{array}{l}\text { "[I have known her] as a } \\
\text { community worker serving } \\
\text { on several committees of } \\
\text { various types, and as a friend } \\
\text { for probably close to 25 } \\
\text { years." T824-25 }\end{array}$ & $\begin{array}{c}\text { Friend; } \\
\text { Church, Civic Org., or } \\
\text { Club }\end{array}$ \\
\hline
\end{tabular}




\begin{tabular}{|c|l|c|}
\hline Nominee & \multicolumn{1}{|c|}{ Relationship } & \multicolumn{1}{c|}{ Characterization } \\
\hline William Parker & $\begin{array}{l}\text { "[I have known him as a] } \\
\text { casual acquaintance for } \\
\text { probably 35 years; as a fellow } \\
\text { club member [at the New } \\
\text { Century Club, a men's club } \\
\text { in Pasadena], probably 15 } \\
\text { years." T826 }\end{array}$ & $\begin{array}{c}\text { Church, Civic Org., or } \\
\text { Club }\end{array}$ \\
\hline Lorraine Zeutzius & $\begin{array}{l}\text { "Well, my first acquaintance } \\
\text { [with her] was as a neighbor } \\
\text { living across the street. } \\
\text { probabiy 15 years. [She is a] } \\
\text { family friend, neighbor." } \\
\text { T826 }\end{array}$ & \\
\hline Hilles Beddell & $\begin{array}{l}\text { "[I knew him for p]robably } \\
\text { 20 years. He is primarily in } \\
\text { civic activities. My principal } \\
\text { acquaintance with him was in } \\
\text { the Tournament of Roses, } \\
\text { Pasadena." T827 }\end{array}$ & Neighbor \\
\hline May Lensing & $\begin{array}{l}\text { "I have known Mrs. Lensing } \\
\text { probably six or seven years. I } \\
\text { was first acquainted with- } \\
\text { her daughter and my daughter } \\
\text { were very close friends, and } \\
\text { we became family friends." } \\
\text { T827 }\end{array}$ & Club \\
\hline
\end{tabular}

JUDGE JAMES G. WHYTE T278

\begin{tabular}{|c|l|c|}
\hline Nominee & \multicolumn{1}{|c|}{ Relationship } & Characterization \\
\hline Gladys Covington & $\begin{array}{l}\text { "Oh, I have known her for } \\
\text { perhaps 15 years. She had } \\
\text { three sons in the same school } \\
\text { that my sons attended. I have } \\
\text { known her in connection with } \\
\text { [her] business, the Betsy Ross } \\
\text { Ice Cream Company. I know } \\
\text { her husband as an attorney in } \\
\text { Ontario [California], and I } \\
\text { have known her both through } \\
\text { school and socially." T281 }\end{array}$ & Business Acquaintance \\
\hline Stanley E. Barnes & $\begin{array}{l}\text { "Mr. Barnes was ... in the } \\
\text { building business, and } \\
\text { constructed a home for me } \\
\text { when I first moved into } \\
\text { Claremont. He was a member } \\
\text { of a bridge club where I } \\
\text { played bridge for several } \\
\text { years, and I have known him } \\
\text { as a member of the Chamber } \\
\text { of Commerce, and generally } \\
\text { in the business world in the } \\
\text { community." T282 }\end{array}$ & Church, Civic Org.. or \\
\hline
\end{tabular}




\begin{tabular}{|c|l|c|}
\hline Nominee & \multicolumn{1}{|c|}{ Relationship } & \multicolumn{1}{c|}{ Characterization } \\
\hline 1961 & $\begin{array}{c}\text { "He was my commanding } \\
\text { officer when I was in the } \\
\text { R.O.T.C. at Pomona College, } \\
\text { 1924 to '28. He also is a } \\
\text { member of the same bridge } \\
\text { club I mentioned Mr. Barnes } \\
\text { was a member of." T282 }\end{array}$ & \\
\hline Dudley B. Woodbridge & $\begin{array}{l}\text { "I knew Mr. Woodbridge } \\
\text { when he was manager of } \\
\end{array}$ & \\
& $\begin{array}{l}\text { Pomona Branch of the Bank } \\
\text { of America, and had had } \\
\text { business dealings with him in } \\
\text { connection with estates I had } \\
\text { handled when I was an } \\
\text { attorney. I also knew him } \\
\text { personally. He had been a } \\
\text { friend of my father's during } \\
\text { my father's lifetime." T283 }\end{array}$ & \\
\hline Robert L. Strail & $\begin{array}{l}\text { "He was my track coach } \\
\text { when I was at Pomona }\end{array}$ \\
1964 & $\begin{array}{l}\text { College, 1924 to '28. I have } \\
\text { known him personally and } \\
\text { intimately since that date." } \\
\text { T283 }\end{array}$ \\
\hline
\end{tabular}

Judge THOMAS C. YAGER T808

\begin{tabular}{|c|l|c|}
\hline Nóminee & \multicolumn{1}{|c|}{ Relationship } & Characterization \\
\hline Jean Haskell & $\begin{array}{l}\text { "I believe it is Miss Haskell, } \\
\text { as I recall, [who] was a friend } \\
\text { of my late aunt. She was a } \\
\text { school principal, as I recall." } \\
\text { T809-10 }\end{array}$ & \\
\hline Eiizabeth Chevalier & $\begin{array}{l}\text { "I recall I met her a number } \\
\text { of years ago and I have seen } \\
\text { her very infrequently.... I } \\
\text { believe I met her socially." } \\
\text { T810 }\end{array}$ & \\
\hline Catherine Messner & $\begin{array}{l}\text { "Well, I first met Mrs. } \\
\text { Messner when she was at }\end{array}$ & \\
& $\begin{array}{l}\text { UCLA, and I was just } \\
\text { entering the school, and Mrs. } \\
\text { Messner has been a very } \\
\text { good friend of mine, as her } \\
\text { husband has, for many } \\
\text { years." T810-11 }\end{array}$ & \\
\hline Lombard Smith & $\begin{array}{l}\text { "I recall meeting the } \\
\text { gentleman, and I really don't } \\
\text { 1962 }\end{array}$ & Fricnd \\
& that ...." T811 & No Recollection \\
\hline
\end{tabular}




\begin{tabular}{|c|c|c|}
\hline Nominee & Relationship & Characterization \\
\hline Gladys Maloney & $\begin{array}{l}\text { "I have known Mrs. Maloney } \\
\text { socially for many years. Mrs. } \\
\text { Maloney is the wife of the } \\
\text { doctor who is the son of the } \\
\text { doctor who brought me into } \\
\text { the world..." T812 }\end{array}$ & $\begin{array}{c}\text { Friend; } \\
\text { Spouse of Acquaintance }\end{array}$ \\
\hline Leo Hubbard & $\begin{array}{l}\text { "Mr. Hubbard is a member of } \\
\text { the American Legion } \\
\text { Luncheon Club which I } \\
\text { sometimes attend, and I have } \\
\text { known him a number of years } \\
\text { in that capacity." T813 }\end{array}$ & $\begin{array}{l}\text { Church. Civic Org., or } \\
\text { Club }\end{array}$ \\
\hline Lillian Parks & $\begin{array}{l}\text { "I have known her for many } \\
\text { years. She is now remarried, } \\
\text { and I don't recall her new } \\
\text { name. She was a very good } \\
\text { friend of my wife's, and a } \\
\text { friend of mine for many } \\
\text { years." T813 }\end{array}$ & Friend \\
\hline Isabella Topper & $\begin{array}{l}\text { "All I recall about that lady, I } \\
\text { have met her, had a } \\
\text { discussion with her, and } \\
\text { nominated her, and she was } \\
\text { recommended by other } \\
\text { people." T813 }\end{array}$ & Recommended \\
\hline Charles Minsky & $\begin{array}{l}\text { "I met Mr. Minsky, and } \\
\text { again had a discussion with } \\
\text { him. Mr. Minsky is the father } \\
\text { of a lawyer whom I } \\
\text { know. . . I'm sure [the } \\
\text { lawyer] recommended his } \\
\text { father." T813 }\end{array}$ & Recommended \\
\hline Corridon T. Hill & $\begin{array}{l}\text { "Corey Hill ... has for } \\
\text { many, many years been a } \\
\text { leading member of the } \\
\text { American Legion Post of } \\
\text { which I have been a member } \\
\text { for approximately } 20 \text { years." } \\
\text { T814 }\end{array}$ & $\begin{array}{l}\text { Church. Civic Org., or } \\
\text { Club }\end{array}$ \\
\hline Marshall Chlavin & $\begin{array}{l}\text { "Mr. Chlavin is a fellow } \\
\text { alumnus of Los Angeles High } \\
\text { School with me. I have } \\
\text { known him for many years in } \\
\text { the capacity of the alumni } \\
\text { association of that } \\
\text { school ...." T814 }\end{array}$ & $\begin{array}{c}\text { Friend; } \\
\text { Church, Civic Org., or } \\
\text { Club }\end{array}$ \\
\hline Elizabeth Snayd & $\begin{array}{l}\text { "I have no recollection of } \\
\text { her, except as I have } \\
\text { indicated about a few of the } \\
\text { others, that I had met her and } \\
\text { had a discussion with her, } \\
\text { and she was recommended, } \\
\text { and I nominated her." T814 }\end{array}$ & Recommended \\
\hline
\end{tabular}


Nominee

Mrs. Freddy Minsky
Relationship

"That is the wife of Mr.

Minsky, and the mother of

Bernard Minsky, the lawyer."

T815
Characterization

Recommended

\section{APPENDIX B: SUMMARY OF THE RELATIONSHIP BETWEEN JUDGES AND GRAND JURY NOMINEES, 1959-1968}

\begin{tabular}{|l|c|c|c|c|c|c|c|c|c|c|}
\hline \multicolumn{1}{|c|}{ Judge } & Nm. & F & C & BA & Nb. & SA & FM & R & NR & U \\
\hline Breitenbach & 14 & 3 & 8 & & 2 & 1 & & 1 & & \\
\hline Call & 11 & 2 & 8 & & & 3 & & & & 3 \\
\hline Chantry & 8 & & 7 & & & & & 1 & & \\
\hline Diether & 6 & 6 & & 2 & & & & & & \\
\hline Dockweiler & 14 & 2 & 1 & 1 & 6 & 1 & 1 & 3 & & \\
\hline Doherty & 12 & 8 & & 1 & & 1 & & & 1 & 1 \\
\hline Farley & 6 & 1 & & & & 1 & 1 & 4 & & \\
\hline Feinerman & 4 & 2 & 1 & 1 & & 2 & & & & \\
\hline Fildew & 11 & 11 & & 3 & & 1 & & & & \\
\hline Frazer & 7 & 4 & 2 & & & & & 1 & & \\
\hline Greenfield & 2 & 1 & & 1 & & & & & & 1 \\
\hline Gumpert & 13 & 10 & & & 1 & & 2 & & & \\
\hline Huls & 9 & 7 & 1 & 1 & & & & 1 & & \\
\hline Irwin & 6 & 6 & & 4 & 2 & & & & & \\
\hline Jefferson & 8 & 1 & 4 & 2 & & 1 & & 1 & & \\
\hline Kaufman & 4 & 3 & & & & & & 1 & & \\
\hline Keene & 3 & 1 & & 1 & 1 & & & 1 & & \\
\hline Koenig & 6 & 6 & 1 & 1 & & & & & & \\
\hline Landis & 6 & 6 & 1 & & & & & & & \\
\hline Levit & 7 & 5 & & 3 & 1 & 2 & & & & \\
\hline Marshall & 7 & 4 & 1 & & & 1 & & 1 & & \\
\hline Neeley & 12 & 4 & 9 & & 1 & & & & & 1 \\
\hline Noble & 7 & 5 & 3 & 4 & & & & 1 & & \\
\hline Nutter & 8 & 4 & 1 & & 2 & 2 & & 1 & & \\
\hline Rhone & 14 & 8 & 8 & 4 & 1 & & & & & \\
\hline Roberts & 5 & 3 & & & & & & 2 & & \\
\hline Sax & 5 & 3 & & 2 & 1 & 1 & & & & \\
\hline Schauer & 5 & 3 & & & & & & 1 & & 1 \\
\hline Schweitzer & 7 & 3 & 2 & & 1 & & & 1 & & \\
\hline Selber & 3 & 2 & & & & & & 1 & & \\
\hline Sprankle & 6 & 4 & 3 & & 1 & & & & & \\
\hline Whyte & 6 & 4 & 2 & 3 & & & & & & \\
\hline Yager & 13 & 4 & 3 & & & 1 & & 4 & 1 & 2 \\
\hline Total & 255 & 136 & 66 & 34 & 20 & 18 & 4 & 26 & 2 & 9 \\
\hline Percentage* & & $53 \%$ & $26 \%$ & $13 \%$ & $8 \%$ & $7 \%$ & $2 \%$ & $10 \%$ & $1 \%$ & $4 \%$ \\
\hline
\end{tabular}

Legend: $\mathrm{Nm} .=$ Nominations; $\mathrm{F}=$ Friend; $\mathrm{C}=$ Church, Civic Org., or Club; BA = Business Acquaintance; $\mathrm{Nb} .=$ Neighbor; $\mathrm{SA}=$ Spouse of Acquaintance; $\mathrm{FM}=$ Family Member;

$\mathrm{R}=$ Recommended; $\mathrm{NR}=$ No Recollection; $\mathrm{U}=$ Uncharacterized 


\section{APPENDIX C: THE CROSS-SECTION REQUIREMENT}

This appendix compiles in table format the responses of each judge to several questions regarding the "fair cross section" requirement. Specifically, it tabulates responses to questions about whether the judge recalled the letter forwarded by the chief judge regarding grand juror selection; whether the judge agreed with the crosssection requirement; whether he made any effort to comply with the requirement; and if so, how, and if not, why not. "[NA]" indicates either that the judge was not asked the question or that he did not answer it.

\section{JUDGE EUGENE H. BRETENBACH}

T426

\begin{tabular}{|l|l|}
\hline Recall Letter & Yes \\
\hline Agree with Req. & [NA] \\
\hline Effort To Comply & "I would hardly know where to begin .... T442 \\
\hline How or Why Not & $\begin{array}{l}\text { "[T]t would take considerable time to actually scek out persons } \\
\text { who would meet the qualifications, statutory qualifications and } \\
\text { my own qualifications of ability and integrity, outstanding } \\
\text { ability and integrity, and I would want to know this personally." } \\
\text { T442 }\end{array}$ \\
\hline
\end{tabular}

JUDGE JOSEPH L. CALL T367

\begin{tabular}{|l|l|}
\hline Recall Letter & No \\
\hline Agree with Req. & "I didn't follow his thinking...." T391 \\
\hline Effort To Comply & No \\
\hline How or Why Not & $\begin{array}{l}\text { "Only as they would come under my observation in the ordinary } \\
\text { affairs of my life, as I met people, as I saw them, as I analyzed } \\
\text { them, as I heard of them as outstanding citizens. .. I don't want } \\
\text { to nominate people I don't know." T393 }\end{array}$ \\
\hline
\end{tabular}

JUdGE KENNETH N. CHANTRY T559

\begin{tabular}{|l|l|}
\hline Recall Letter & Yes \\
\hline Agree with Req. & Yes \\
\hline Effort To Comply & "F]rom time to time I have that duty and obligation." T577 \\
\hline How or Why Not & [NA] \\
\hline
\end{tabular}

JUDGE LEONARD A. DIETHER

T512

\begin{tabular}{|l|l|}
\hline Recall Letter & Yes \\
\hline Agree with Req. & "No, I don't." T519 \\
\hline Effort To Comply & $\begin{array}{l}\text { "No. No more than I would French, or Chinese, or Japanese, or } \\
\text { Russian, or Catholics, or Protestants, or any other } \\
\text { characteristic." T519 }\end{array}$ \\
\hline How or Why Not & $\begin{array}{l}\text { "I think it is the duty of each Judge to pick a nomince who he } \\
\text { feels is qualified for the position, regardless of what race, } \\
\text { nationality, or religion he may be. It doesn't make any } \\
\text { difference." T519 }\end{array}$ \\
\hline
\end{tabular}


JUDGE GEORGE A. DOCKWEILER $\mathrm{T} 402$

\begin{tabular}{|l|l|}
\hline Recall Letter & Yes \\
\hline Agree with Req. & {$[\mathrm{NA}]$} \\
\hline Effort To Comply & No \\
\hline How or Why Not & $\begin{array}{l}\text { "I wouldn't know where to go to find these people. You know } \\
\text { what I mean. I didn't know of anybody of Mexican extraction or } \\
\text { Spanish extraction, or Negro extraction, or Japanese, or any-I } \\
\text { didn't know any of those people that I felt would qualify. Of } \\
\text { course, we have had help in the household for years and years } \\
\text { that have been of the Negro extraction, but these are working } \\
\text { people. They obviously couldn't afford to take the time off to } \\
\text { serve as Grand Jurors, as fine people as they were." T414-15 }\end{array}$ \\
\hline
\end{tabular}

\section{JUDGE EMMETT E. DOHERTY} T320

\begin{tabular}{|l|l|}
\hline Recall Letter & Yes \\
\hline Agree with Req. & $\begin{array}{l}\text { "I never received any orders. ... I was never bound by anything } \\
\text { more than my own discretion." T330 }\end{array}$ \\
\hline Effort To Comply & Yes \\
\hline How or Why Not & $\begin{array}{l}\text { "I asked some of the colored men in the court if they could } \\
\text { recommend some persons that were well-qualified...." T332 }\end{array}$ \\
\hline
\end{tabular}

\section{JUDGE GOSCOE O. FARLEY}

T867

\begin{tabular}{|l|l|}
\hline Recall Letter & [NA] \\
\hline Agree with Req. & [NA] \\
\hline Effort To Comply & "I don't consider race at all."* T875 \\
\hline How or Why Not & $\begin{array}{l}\text { "I think if each Judge tried to pick the best people he can, by } \\
\text { and large the races will be equally represented."* T875 }\end{array}$ \\
\hline
\end{tabular}

* Testimony on cross-examination

\section{JUDGE ROBERT FEINERMAN}

T546

\begin{tabular}{|l|l|}
\hline Recall Letter & Yes \\
\hline Agree with Req. & $\begin{array}{l}\text { "[N]o. My primary motivation was to get the most qualified } \\
\text { people, regardless of race, color, creed, or religion, or national } \\
\text { origin." T556 }\end{array}$ \\
\hline Effort To Comply & No \\
\hline How or Why Not & $\begin{array}{l}\text { "What I was interested in was getting qualified people to serve } \\
\text { on the Grand Jury, regardless of their ethnic and racial } \\
\text { background, because I don't believe in quota systems, per } \\
\text { se..." T556-57 }\end{array}$ \\
\hline
\end{tabular}

\section{JUDGE RICHARD C. FILDEW}

T634

\begin{tabular}{|l|l|}
\hline Recall Letter & Yes \\
\hline Agree with Req. & $\begin{array}{l}\text { "I have no quarrel with it, but if he is inferring [sic] we should } \\
\text { pick someone because they are Mexicans, Japanese, Jewish, } \\
\text { somebody like that, then I am 100 percent against it." T652 }\end{array}$ \\
\hline Effort To Comply & [NA] \\
\hline
\end{tabular}


How or Why Not "I think that if they are qualified Mexican-Americans, they should be selected, and shouldn't be excluded because they are Mexican-Americans, but just because he is a Mexican-

American, or an American-Indian, or a Negro he shouldn't be picked, he should have other qualifications." T652

\section{JUDGE JOHN FRAZER}

T527

\begin{tabular}{|l|l|}
\hline Recall Letter & No \\
\hline Agree with Req. & "I think it is a good thing." T538 \\
\hline Effort To Comply & "I did, of those that I know." T538 \\
\hline How or Why Not & $\begin{array}{l}\text { "Actually, to me, what a person's race is is a minimal } \\
\text { requirement. It doesn't make any difference to me whether they } \\
\text { are Jewish, or black, or Spanish, or Mexican, or Oriental, or } \\
\text { Caucasian, as far as I am concemed. If they are qualified, I } \\
\text { would as soon appoint one as the other." T539-40 }\end{array}$ \\
\hline
\end{tabular}

\section{JUDGE SAMUEL GREeNFIELD}

$\mathrm{T} 719$

\begin{tabular}{|l|l|}
\hline Recall Letter & Yes \\
\hline Agree with Req. & "[I]t is a proper objective ... . T724 \\
\hline Effort To Comply & "I did not." T724 \\
\hline How or Why Not & "It doesn't enter my mind." * T727 \\
\hline
\end{tabular}

* Testimony on cross-examination

JUDGE EMIL GUMPERT

$\mathrm{T} 294$

\begin{tabular}{|l|l|}
\hline Recall Letter & No \\
\hline Agree with Req. & {$[\mathrm{NA}]$} \\
\hline Effort To Comply & No \\
\hline How or Why Not & $\begin{array}{l}\text { "I thought that I would try to have Mr. George selected ...." } \\
\text { T299 }\end{array}$ \\
\hline
\end{tabular}

JUDGE HAROLD HULS

T621

\begin{tabular}{|l|l|}
\hline Recall Letter & {$[\mathrm{NA}]$} \\
\hline Agree with Req. & "Of course." T629 \\
\hline Effort To Comply & "I can't say that I did." T630 \\
\hline How or Why Not & "I frankly didn't know anyone well enough ...." T629 \\
\hline
\end{tabular}

JUDGE AUBREY N. IRIVIN T486

\begin{tabular}{|l|l|}
\hline Recall Letter & Yes \\
\hline Agree with Req. & $\begin{array}{l}\text { "I would say that getting qualified people of various races is } \\
\text { good." T493 }\end{array}$ \\
\hline Effort To Comply & "I don't think I was obligated." T493 \\
\hline How or Why Not & $\begin{array}{l}\text { "I selected the best people that I knew available for the } \\
\text { job...." T494 }\end{array}$ \\
\hline
\end{tabular}


JUDGE BERNARD S. JEFFERSON

T464

\begin{tabular}{|l|l|}
\hline Recall Letter & Yes \\
\hline Agree with Req. & "Certainly." T472 \\
\hline Effort To Comply & No \\
\hline How or Why Not & $\begin{array}{l}\text { "When the groups or races are in the category [that] cannot give } \\
\text { that kind of time, then it is difficult to find them." T474 }\end{array}$ \\
\hline
\end{tabular}

JUDGE SIDNEY W. KAUFMAN

T447

\begin{tabular}{|l|l|}
\hline Recall Letter & Yes \\
\hline Agree with Req. & $\begin{array}{l}\text { "I don't think it is as important to have various racial } \\
\text { backgrounds in comparison to having people of great ability and } \\
\text { integrity.... T454 }\end{array}$ \\
\hline Effort To Comply & No \\
\hline How or Why Not & $\begin{array}{l}\text { "[H]ad I known ... of anyone of a minority group who might } \\
\text { have been qualified, and who would have accepted, I would } \\
\text { have gone out of my way to have appointed him, if I could } \\
\text { have."* T457 }\end{array}$ \\
\hline
\end{tabular}

* Testimony on cross-examination

JUdGE WILLIAM B. KEENE

T755

\begin{tabular}{|l|l|}
\hline Recall Letter & [NA] \\
\hline Agree with Req. & Yes \\
\hline Effort To Comply & "I trust that I will when I finish a few more years." T761 \\
\hline How or Why Not & $\begin{array}{l}\text { "It is difficult to find people who will indicate a willingness to } \\
\text { serve ...."T761 }\end{array}$ \\
\hline
\end{tabular}

\section{JUDGE BEN KOENIG}

T497

\begin{tabular}{|l|l|}
\hline Recall Letter & Yes \\
\hline Agree with Req. & "I haven't any objection to any racial group ...." T504 \\
\hline Effort To Comply & No \\
\hline How or Why Not & $\begin{array}{l}\text { "I have to know the people before I recommend them. .. They } \\
\text { never made any effort to communicate with me, either the } \\
\text { organizations or the people, to indicate their desire to serve on } \\
\text { the Grand Jury." T504-05 }\end{array}$ \\
\hline
\end{tabular}

\section{JUDGE BENJAMIN LANDIS}

T600

\begin{tabular}{|l|l|}
\hline Recall Letter & Yes \\
\hline Agree with Req. & "I think so." T617 \\
\hline Effort To Comply & "I have not, because I don't know any." T617 \\
\hline How or Why Not & $\begin{array}{l}\text { "[M]y personal conviction is that a Judge can't nominate } \\
\text { anyone unless he knows them intimately, and I have never } \\
\text { nominated anyone unless I know them fairly well." T618 }\end{array}$ \\
\hline
\end{tabular}


JUDGE WILLIAM H. LEVIT T580

\begin{tabular}{|l|l|}
\hline Recall Letter & Yes \\
\hline Agree with Req. & Yes \\
\hline Effort To Comply & "Not at all." T593 \\
\hline How or Why Not & $\begin{array}{l}\text { "The only attempt I made, as I have indicated, was to select } \\
\text { people whom I felt were qualified to serve, not on any basis of } \\
\text { race, or religion, or nationality, anything like that." T597 }\end{array}$ \\
\hline
\end{tabular}

JUDGE ARTHUR K. MARSHALL T879

\begin{tabular}{|l|l|}
\hline Recall Letter & [NA] \\
\hline Agree with Req. & $\begin{array}{l}\text { "[T]t is a good idea ... [but] the first consideration is to get } \\
\text { people who are capable ...." T884 }\end{array}$ \\
\hline Effort To Comply & $\begin{array}{l}\text { "I have inquired of people who I think might know some people } \\
\text { in other groups...." T885 }\end{array}$ \\
\hline How or Why Not & {$[$ NA] } \\
\hline
\end{tabular}

JUdGE WILLIAM B. NEELEY T781

\begin{tabular}{|l|l|}
\hline Recall Letter & [NA] \\
\hline Agree with Req. & $\begin{array}{l}\text { "I think it is far better if we have a Grand Jury pool of } \\
\text { individuals who ... have no personal bias or prejudice." T795 }\end{array}$ \\
\hline Effort To Comply & [NA] \\
\hline How or Why Not & $\begin{array}{l}\text { "I had a Negro doctor who was invited to my home for dinner } \\
\text { with a number of Judges, and I have the highest regard for } \\
\text { him .... I would gladly nominate him for the Grand Jury, but } \\
\text { he would-he couldn't serve, he is too ... he couldn't take the } \\
\text { time." T800 }\end{array}$ \\
\hline
\end{tabular}

JUDGE H. BURTON NOBLE

T743

\begin{tabular}{|l|l|}
\hline Recall Letter & [NA] \\
\hline Agree with Reg. & "I think they ought to be represented." T749 \\
\hline Effort To Comply & No \\
\hline How or Why Not & "I wouldn't hesitate to if I knew where to go." T749 \\
\hline
\end{tabular}

JUDGE RALPH H. NUTTER

T683

\begin{tabular}{|l|l|}
\hline Recall Letter & [NA] \\
\hline Agree with Req. & Yes \\
\hline Effort To Comply & $\begin{array}{l}\text { "I made a particular attempt to nominate members of minority } \\
\text { groups." T688 }\end{array}$ \\
\hline How or Why Not & [NA] \\
\hline
\end{tabular}


JUDGE BAYARD RHONE

T659

\begin{tabular}{|l|l|}
\hline Recall Letter & {$[\mathrm{NA}]$} \\
\hline Agree with Req. & $\begin{array}{l}\text { "I don't disagree with it. . . That doesn't mean I agree with it." } \\
\text { T677-78 }\end{array}$ \\
\hline Effort To Comply & No \\
\hline How or Why Not & $\begin{array}{l}\text { "I have only taken those persons whom I personally knew and } \\
\text { could vouch for their qualifications." T679 }\end{array}$ \\
\hline
\end{tabular}

JUDGE RAYMOND R. ROBERTS

$\mathrm{T} 733$

\begin{tabular}{|l|l|}
\hline Recall Letter & Yes \\
\hline Agree with Req. & "Absolutely." T739 \\
\hline Effort To Comply & "I do it." T739 \\
\hline How or Why Not & $\begin{array}{l}\text { "I feel in 10 years ... that I will consciously put a name in } \\
\text { nomination of every minority group, whether it be religion, } \\
\text { geography, or race." T741 }\end{array}$ \\
\hline
\end{tabular}

JUDGE EUGENE E. SAX

T836

\begin{tabular}{|l|l|}
\hline Recall Letter & {$[\mathrm{NA}]$} \\
\hline Agree with Req. & $\begin{array}{l}\text { "[Jurors] should be those who can best perform the function of } \\
\text { the Grand Jury." T843 }\end{array}$ \\
\hline Effort To Comply & "I have tried ...." T843 \\
\hline How or Why Not & $\begin{array}{l}\text { "[T]here are very few people who have the qualifications ... } \\
\text { and who are able to leave their places of employment or their } \\
\text { occupation for that length of time." T844 }\end{array}$ \\
\hline
\end{tabular}

\section{JUDGE RICHARD SCHAUER}

T848

\begin{tabular}{|l|l|}
\hline Recall Letter & {$[\mathrm{NA}]$} \\
\hline Agree with Req. & $\begin{array}{l}\text { "[Only] to the extent that those persons are known to me, to the } \\
\text { extent that I can verify their background." T856 }\end{array}$ \\
\hline Effort To Comply & "Mentally I have." T856 \\
\hline How or Why Not & $\begin{array}{l}\text { "[F]or reasons obvious to anybody, and known to me, they } \\
\text { could not serve." T856 }\end{array}$ \\
\hline
\end{tabular}

\section{JUDGE HAROLD W. SCHWEITZER}

T304

\begin{tabular}{|l|l|}
\hline Recall Letter & Yes \\
\hline Agree with Req. & {$[\mathrm{NA}]$} \\
\hline Effort To Comply & "I think it was just once." T312 \\
\hline How or Why Not & $\begin{array}{l}\text { "[T]hey didn't have the time to give to it, they had families to } \\
\text { support ....* T313 }\end{array}$ \\
\hline
\end{tabular}

* Testimony on cross-examination 
Judge BERNARd S. SEl.BER

T769

\begin{tabular}{|l|l|}
\hline Recall Letter & {$[\mathrm{NA}]$} \\
\hline Agree with Reg. & Yes \\
\hline Effort To Comply & "I have attempted [to do so]." T773 \\
\hline How or Why Not & $\begin{array}{l}\text { "I am not suggesting that we place quota limits on the Grand } \\
\text { Jury, but I certainly think ... it should tend to reflect the } \\
\text { presence of the minority groups, yes." T778 }\end{array}$ \\
\hline
\end{tabular}

JUDGE JOSEPH A. SPRANKLE

T824

\begin{tabular}{|l|l|}
\hline Recall Letter & {$[\mathrm{NA}]$} \\
\hline Agree with Req. & "I wouldn't believe in trying to stack it that way." T830 \\
\hline Effort To Comply & "I don't think it is required." T832 \\
\hline How or Why Not & $\begin{array}{l}\text { "I move about in a very limited circle of people ... and it } \\
\text { would present a very difficult problem for me to seck out any } \\
\text { particular race...." T831-32 }\end{array}$ \\
\hline
\end{tabular}

JUDGE JAMES G. WHYTE

T278

\begin{tabular}{|l|l|}
\hline Recall Letter & No \\
\hline Agree with Req. & $\begin{array}{l}\text { "The matter of the appointments of Grand Jurors was primarily } \\
\text { in the discretion of the particular Judge, and I didn't pay too } \\
\text { much attention to any suggestion from the Executive Officer or } \\
\text { anyone who was not a Judge as to who the nominations might } \\
\text { be." T288 }\end{array}$ \\
\hline Effort To Comply & $\begin{array}{l}\text { "II made no] conscious attempt to put into effect that } \\
\text { policy .... T289 }\end{array}$ \\
\hline How or Why Not & $\begin{array}{l}\text { "I went out to get the available people who I thought were the } \\
\text { best qualified ...." T289 }\end{array}$ \\
\hline
\end{tabular}

JUDGE THOMAS C. YAGER

T808

\begin{tabular}{|l|l|}
\hline Recall Letter & {$[\mathrm{NA}]$} \\
\hline Agree with Req. & {$[\mathrm{NA}]$} \\
\hline Effort To Comply & {$[\mathrm{NA}]$} \\
\hline How or Why Not & {$[\mathrm{NA}]$} \\
\hline
\end{tabular}


APPENDIX D: SUMMARY OF GRAND JUROR SELECTION METHODS IN TWENTY CALIFORNIA COUNTIES, 1999*

\begin{tabular}{|c|c|c|c|c|c|}
\hline \multirow[b]{2}{*}{ County } & \multicolumn{3}{|c|}{ IDENTIFICATION OE POTENTIAL JURORS } & \multicolumn{2}{|c|}{ FINAL SELECTION } \\
\hline & $\begin{array}{c}\text { Volunteers } \\
\text { Solicited }\end{array}$ & $\begin{array}{l}\text { Drawn } \\
\text { from Petit } \\
\text { Jury Pool }\end{array}$ & $\begin{array}{c}\text { Judges } \\
\text { Submit } \\
\text { Nominations }\end{array}$ & $\begin{array}{c}\text { Judge or } \\
\text { Judges } \\
\text { Select } \\
\text { Pool }\end{array}$ & $\begin{array}{c}\text { Jurors } \\
\text { Randomly } \\
\text { Drawn from } \\
\text { Pool }\end{array}$ \\
\hline Alameda & & & $\bar{X}$ & $x$ & (30) \\
\hline Colusa & & $\bar{x}$ & & $\bar{X}$ & (30) \\
\hline Fresno & $X^{465}$ & & $\mathrm{X}^{466}$ & $x$ & $x$ \\
\hline Imperial & & $\bar{x}$ & & & $\mathrm{X}$ \\
\hline Kern & $\mathrm{X}$ & & $\mathrm{X}$ & $\mathrm{X}$ & $(45-60)$ \\
\hline Kings & & $\mathrm{X}^{467}$ & & 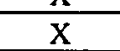 & $(30)$ \\
\hline Los Angeles & $X^{465}$ & & $\overline{\mathrm{X}}$ & & $x$ \\
\hline Madera & & $\mathrm{X}$ & & $\mathrm{X}$ & $\mathrm{x}$ \\
\hline Merced & & $\mathrm{X}$ & $\mathrm{x}$ & $\mathrm{X}$ & $(30)^{468}$ \\
\hline Monterey & $\mathrm{X}$ & & & $\mathrm{X}$ & $(30)$ \\
\hline Orange & $\mathrm{X}$ & & & $\mathrm{X}$ & $(30)$ \\
\hline Riverside & $\mathrm{X}$ & & & $x$ & $x$ \\
\hline San Benito & $\mathrm{X}$ & & $\mathrm{X}^{469}$ & $x$ & $\mathrm{X}$ \\
\hline San Bernardino & $\mathrm{X}$ & & $\mathrm{x}$ & $X^{\sqrt{30}}$ & \\
\hline San Joaquin & & $\mathrm{X}$ & $x^{37}$ & $X$ & $(50-75)$ \\
\hline Santa Barbara & $\mathrm{X}$ & & & $\mathrm{X}$ & (30) \\
\hline Santa Clara & $X$ & & $\mathrm{X}$ & $x$ & $(30)$ \\
\hline Tulare & $\mathrm{X}$ & & $\mathrm{X}$ & $\mathrm{X}$ & (30) \\
\hline Ventura & $\mathrm{X}$ & & $x$ & $\mathrm{X}$ & (30) \\
\hline Yolo & $\bar{X}$ & $\mathrm{X}$ & & $\mathrm{x}$ & (30) \\
\hline Total & 13 & 7 & 11 & 17 & 19 \\
\hline Percentage & $(65 \%)$ & $(35 \%)$ & $(55 \%)$ & $(85 \%)$ & $(95 \%)$ \\
\hline
\end{tabular}

* The counties selected were those studied in California Rural Legal Assistance, A Study of Grand Jury Service by Persons of Spanish Surname and by Indians in Selected California Counties, U.S. COMM'N ON CIVIL RIGHTS, MEXICAN AMERICANS AND THE ADMINISTRATION OF JUSTICE IN THE SOUTHWEST 113 (1970). Information was gathered through published documents, web sites, and telephone interviews with superior court officials; more detailed information regarding cach county is on file with the author.

464. Pool size is indicated in parentheses where information is available.

465. Persons who wish to be considered as potential grand jurors may apply directly to the court; volunteers are not solicited.

466. Current grand jurors may also nominate persons.

467. Potential jurors are drawn from voter registration rolls.

468. Judges may appoint a foreperson from outside of the pool.

469. Judges nominate grand jurors if an insufficient number of persons apply voluntarily.

470. Judges select grand jurors directly.

471. Mayors of the largest cities in the county, as well as chambers of commerce, may also nominate potential grand jurors. 